Carolina Dalla Pacce

\title{
A sistematização dos recursos administrativos na legislação federal
}

Dissertação apresentada como requisito parcial para obtenção do título de Mestre em Direito do Estado.

Orientador: Prof. Associado Thiago Marrara

Faculdade de Direito da Universidade de São Paulo São Paulo 
Catalogação na Publicação

Dalla Pacce, Carolina

A sistematização dos recursos administrativos na legislação federal / Carolina Dalla Pacce; orientador Thiago Marrara -- São Paulo, 2015.

154

Dissertação (Mestrado - Programa de Pós-Graduação em Direito do Estado) Faculdade de Direito, Universidade de São Paulo, 2015.

1. Lei Federal n. 9.784/1999. 2. Processo Administrativo. 3. Recursos administrativos.

4.Garantias recursais. 5. Legislações Federais. I. Marrara, Thiago, orient. II. Título. 
FOLHA DE APROVAÇÃO

Carolina Dalla Pacce

Recursos administrativos na legislação federal

Dissertação apresentada como requisito parcial para obtenção do título de Mestre pela

Faculdade de Direito da Universidade de São Paulo.

Área de Concentração: Direito do Estado

Aprovada em:

Banca Examinadora:

Professor Associado Thiago Marrara

Instituição: Faculdade de Direito de Ribeirão Preto da Universidade de São Paulo

$\operatorname{Prof}(\mathrm{a}) . \operatorname{Dr}(\mathrm{a})$.

Instituição:

Prof(a). Dr(a).

Instituição: 
aos meus avós

(in memoriam) 
Master of Puppets I'm pulling your strings Twisting your mind and smashing your dreams Blinded by me, you can't see a thing Just call my name, 'cause I'll hear you scream (Master of Puppets - Metallica) 


\section{AGRADECIMENTOS}

Essa dissertação encerra mais uma etapa da minha vida acadêmica e sua realização contou com a participação direta e indireta de diversas pessoas que merecem os devidos agradecimentos.

Primeiramente, gostaria de agradecer ao Programa de Excelência Acadêmica (ProexCapes) pela concessão da bolsa de estudos que possibilitou a execução e desenvolvimento dessa pesquisa acadêmica.

Agradeço, com grande carinho, ao meu orientador, professor associado Thiago Marrara, por todos os ensinamentos, horas dedicadas ao meu crescimento acadêmico, oportunidades e orientações. Acima de tudo, agradeço pela nossa amizade e parceria durante esses três anos.

Aproveito a oportunidade para também agradecer às professoras Vera Cristina Caspari Monteiro e Maria Paula Dallari Bucci pelos valiosos comentários dispensados à minha qualificação, os quais contribuíram imensamente para a elaboração desse trabalho.

Agradeço ao meu grande amigo, o professor associado Eleazar Chaib, da Faculdade de Medicina da Universidade de São Paulo, por todas as divertidas conversas que tivemos nesses últimos anos e especialmente por ter me ajudado durante o período mais difícil desses três anos.

Gostaria de agradecer profundamente aos amigos do "conjunto 21" da FGV Direito SP pela parceria, apoio, intercâmbio de ideias e, é claro, risadas. Agradeço especialmente à Luciana de Oliveira Ramos, Natalia Langenegger, Guilherme Forma Klafke, Camila Tavares de Moura Brasil Matos, Karina Denari Gomes de Mattos, Ingrid Garbuio Mian, Adriane Sanctis de Brito, Arthur Roberto Capella Giannattasio, Rafael Helou Bresciani, Ricardo Savignani Alvares Leite, Rubens Eduardo Glezer, Diogo Rais Rodrigues Moreira e Angela Rita Franco Donaggio.

Agradeço, com muito carinho, às minhas amigas franciscanas Renata Rocha Villela e Anna Carolina Venturini pelo companheirismo desde os tempos da graduação. 
Aproveito para agradecer de maneira muito especial ao meu melhor amigo, Daniel Falcão Pimentel dos Reis, aquele sem o qual não teria sido possível concluir esse mestrado.

Agradeço à Livia Ortega Gonçalves e Luciana Andréia Silveira Simão, funcionárias da Biblioteca Karl A. Boedecker.

Agradeço imensamente ao meu irmão, Pedro Henrique Dalla Pacce, pela amizade, companheirismo e conversas noturnas sempre muito agradáveis. Agradeço, também, a minha mãe, Marcia do Carmo Dalla Pacce, por todo o carinho.

Gostaria, também, de aproveitar a oportunidade para agradecer à Zélia Santos Silva Souza, por sempre estar presente.

Finalmente, agradeço carinhosamente ao Thiago Rodrigues São Marcos Nogueira, presente em todos os momentos importantes da minha vida acadêmica, dividindo comigo as alegrias e tristezas e sempre me apoiando na realização dos meus sonhos. Obrigada por ter tornado minha vida tão mais prazerosa. 


\section{RESUMO}

A sistematização dos recursos administrativos na legislação federal consiste em um trabalho de elaboração de um modelo de identificação e organização das diversas normas processuais administrativas disciplinadoras das regras de cabimento, processamento e julgamento dos recursos administrativos no âmbito da administração pública federal. Trata-se de uma pesquisa acadêmica de revisão normativa das principais legislações infraconstitucionais administrativas federais desenvolvida a partir da perspectiva das normas gerais de processo administrativo estabelecidas pela Lei Federal n. 9.784/99 (Lei de processo administrativo federal). Inicialmente, são analisados os aspectos históricos e conceituais do processo administrativo brasileiro considerados mais relevantes para a compreensão do sistema recursal administrativo. Posteriormente à fixação desses pressupostos conceituais na primeira parte do trabalho, o estudo direciona-se ao estabelecimento da tipologia recursal administrativa, por meio do exame dos princípios, regras e demais orientações apresentados pela Lei Federal n. 9.784/99. Tendo sido estipulados as espécies recursais, suas características, bem como as regras de cabimento, processamento e julgamento dos recursos administrativos, empreende-se o diagnóstico das legislações infraconstitucionais federais escolhidas com fundamento nos elementos fixados na segunda parte do trabalho. A sistematização dos recursos administrativos na legislação federal tem como finalidade demonstrar que a previsibilidade dos resultados obtida por meio do conhecimento das "regras do jogo" em matéria recursal administrativa, é responsável por um incremento das garantias constitucionais do processo administrativo nos entes públicos federais.

Palavras-chave: processo administrativo; recursos administrativos; lei federal $\mathrm{n}$. 9.784/99; legislação federal; devido processo legal administrativo; garantias recursais. 


\begin{abstract}
The systematization of the administrative appeals in the Brazilian federal legislation aims to establish a model for the identification and organization of the various administrative procedural rules dealing with administrative appeals within the federal administration. This is a revision work of the most important federal administrative legislations, and it is developed from the perspective of the general rules of administrative procedure established by Lei Federal n. 9.784/99 (federal administrative procedure law). Firstly, in order to comprehend the basis of the administrative appeals, this research analyzes the most relevant historical and conceptual aspects of the Brazilian administrative procedure. By establishing the main rules and principles in which the administrative appeals are based, this research makes an effort in order to discover and organize the basic types of administrative appeals determined by Lei Federal n. 9.784/99. Finally, this research develops a diagnosis of how the Brazilian federal legislation deals with administrative appeals. The results are presented in such a way to confirm that when more guarantees related to administrative appeals are given to the citizens, the more they are going to trust their government institutions and in the administrative procedure.
\end{abstract}

Keywords: administrative procedure; administrative appeals, lei federal n. 9.784/99, Brazilian federal legislation, due process of law. 


\section{SUMÁRIO}

Introdução

I - Aspectos históricos e conceituais do processo administrativo: diálogo com o sistema recursal

1. Evolução histórica do processo administrativo no ordenamento jurídico brasileiro

1.1. As etapas evolutivas do processo administrativo......................................... 17

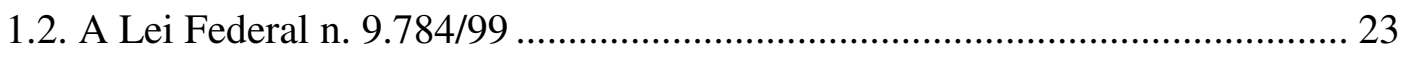

1.2.1. Contextualização: a constitucionalização do processo administrativo e as consequências da inexistência de uma lei geral. .................................................... 23

1.2.2. Processo de elaboração da Lei Federal n. 9.784/99 .............................. 30

1.2.3. Aplicação da Lei Federal n. 9.784/99: norma básica ou norma geral.... 32

2. Análise dos pressupostos dos recursos administrativos.......................................... 35

2.1. Definição de recurso administrativo .............................................................. 35

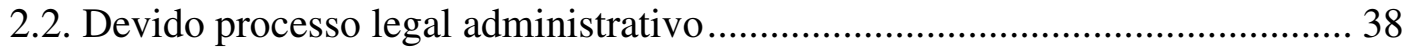

2.3. Recorribilidade das decisões administrativas ................................................ 41

2.4. A questão do duplo grau de jurisdição na esfera administrativa .................... 44

2.5. Considerações acerca dos pressupostos dos recursos administrativos ............ 51

2.6. A confiabilidade das soluções administrativas: peticionar ao Judiciário é mais eficaz do que os recursos administrativos?.

3. Considerações finais sobre os aspectos históricos e conceituais do processo administrativo

II - Tipologia dos recursos administrativos na Lei Federal n. 9.784/99: estabelecimento do paradigma recursal ................................................................................ 59

1. Recursos administrativos e outras espécies recursais .............................................5 59

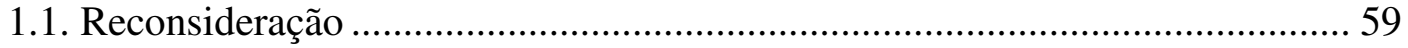

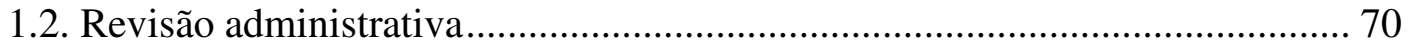

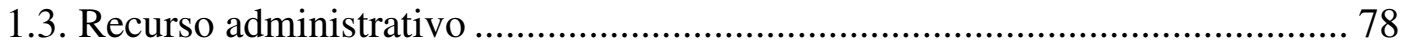

1.3.1. Recurso hierárquico próprio ................................................................ 78

1.3.2. Recurso hierárquico impróprio............................................................ 80

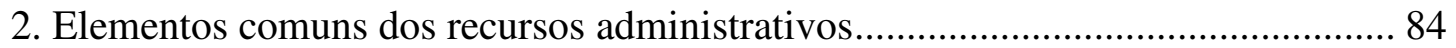

2.1. Gratuidade dos recursos administrativos: recolhimento de custas processuais e

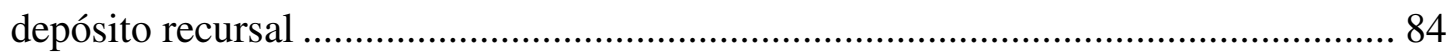

2.2. Legitimidade e competência recursal............................................................ 88

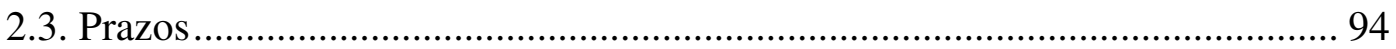




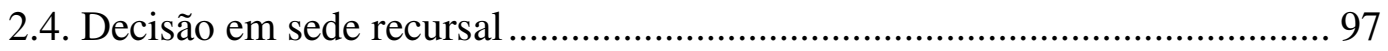

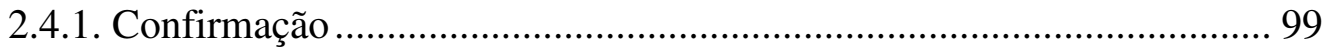

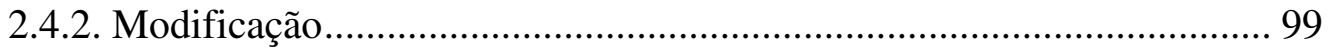

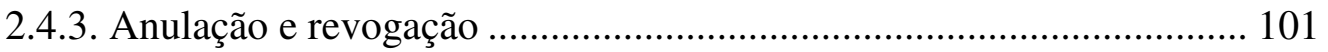

2.5. A reformatio in pejus na decisão recursal ................................................ 102

III - Diagnóstico das garantias recursais nas principais legislações administrativistas federais ............................................................................... 106

1. Lei dos Servidores Públicos Federais ................................................................ 106

1.1. Arranjo normativo e dispersão temática ..................................................... 107

1.2. As garantias recursais na Lei Federal n. 8.112/90: tipologia recursal e regras específicas dessa legislação. ............................................................................... 110

1.2.1. Grupo I: direito de petição .......................................................... 110

1.2.2. Grupo II: processo administrativo disciplinar ................................. 114

1.3. Considerações acerca da Lei dos Servidores Públicos Federais .................. 115

2. A Lei de Licitações e Contratos Administrativos ................................................. 116

2.1. Arranjo normativo e dispersão temática ................................................. 117

2.2. As garantias recursais na Lei Federal n. 8.666/93: tipologia recursal e regras

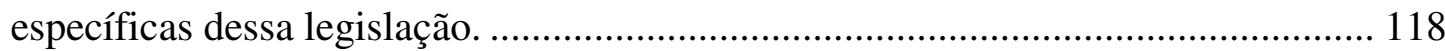

2.3. Considerações acerca da Lei de Licitações e Contratos Administrativos.... 125

3. Legislações infraconstitucionais básicas das agências reguladoras federais ........ 127

3.1. Agências reguladoras instituídas previamente a Lei Federal n. 9.784/99 ... 130

3.2. Agências reguladoras instituídas posteriormente a Lei Federal n. 9.784/99 136

3.3. Considerações acerca das legislações infraconstitucionais básicas das

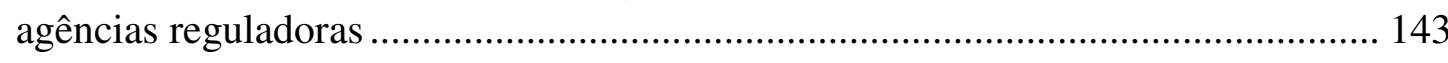

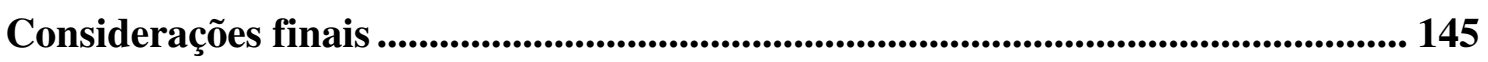

Referências bibliográficas ........................................................................................ 148 


\section{INTRODUÇÃO}

Em razão do término da ditadura militar brasileira, as duas últimas décadas do século XX foram marcadas pelo processo de redemocratização do país, motivo pelo qual promoveu-se uma reforma administrativa estatal baseada na adoção de um modelo de gestão pública que possibilitasse tornar a Administração Pública mais aberta às necessidades dos cidadãos, mais voltada à realização do interesse público e mais eficiente na coordenação dos setores econômicos e da prestação dos serviços públicos (PAULA, 2004, p. 37).

Dessa maneira, durante a gestão do presidente Fernando Henrique Cardoso, teve início a reforma do Estado brasileiro, marcada pela combinação de fatores do modelo de reforma gerencial ${ }^{1}$ com elementos do modelo de reforma societal ${ }^{2}$. Como resultado dessa reforma, a Administração Pública deve orientar suas atividades pela efetivação da eficiência administrativa e pela promoção da participação popular no processo decisório ${ }^{3}$.

Nesse contexto, a constitucionalização do processo administrativo (art. $5^{\circ}, \mathrm{LV}$ ) e a elaboração de uma legislação de normas gerais de processo administrativo (Lei Federal n. 9.784/99) permitiram o estabelecimento de regras processuais mais específicas para o exercício da função administrativa. Assim, a consolidação das garantias processuais administrativas deve ser compreendida como um dos elementos responsáveis por promover a participação popular nos processos administrativos decisórios, pois instrumentaliza os cidadãos dos meios necessários para exercer essa participação.

Como avaliar se a atividade administrativa está realmente promovendo a eficiência administrativa e a participação popular no processo administrativo? Há duas hipóteses: (i) verificar se a legislação infraconstitucional efetivamente assegura os direitos e garantias processuais constitucionalmente previstos ou (ii) investigar se o agente público está realmente aplicando a legislação administrativa de modo a assegurar os direitos e garantias processuais constitucionalmente previstos. Enquanto a primeira

\footnotetext{
1 O modelo gerencial "enfatiza a eficiência administrativa e se baseia no ajuste estrutural, nas recomendações dos organismos multilaterais internacionais e no movimento gerencialista, sendo que sua origem está relacionada com intenso debate sobre a crise de governabilidade e credibilidade do Estado no contexto internacional de reforma do aparelho estatal" (PAULA, 2004, p.41).

${ }^{2}$ Por sua vez, o modelo societal "enfatiza a participação social e procura estruturar um projeto político que repense o modelo de desenvolvimento brasileiro, a estrutura do aparelho de Estado e o paradigma de gestão" (PAULA, 2004, p.41).

${ }^{3}$ Enquanto que a viabilização da eficiência administrativa subordina-se à adoção de medidas concretas, como a edição de normas jurídicas que determinem regras objetivas para o exercício da função administrativa, a articulação da participação popular significa a necessidade de empoderamento do cidadão por meio do exercício da cidadania e da conscientização quanto aos seus direitos (MENDES, 2001, p.9).
} 
hipótese pode ser averiguada por meio de uma revisão normativa, a segunda hipótese pode ser analisada por meio de uma pesquisa empírica dos dados resultantes das decisões administrativas. Embora ambas hipóteses sejam igualmente interessantes, essa pesquisa acadêmica optou por empreender uma revisão normativa da legislação administrativa federal.

Dessa maneira, serão analisadas (i) a Lei Federal n. 9.784/99, principal legislação para o processo administrativo federal, (ii) a Lei Federal n. 8.112/90, legislação responsável pela organização dos servidores públicos federais, (iii) a Lei Federal n. 8.666/93, legislação instituidora das regras de compras e contratações públicas e (iv) as leis básicas das agências reguladoras, entes públicos responsáveis pela regulação de diversos setores econômicos. Com exceção da Lei Federal n. 9.784/99, as demais legislações foram escolhidas por representarem os principais diplomas normativos para a organização da administração pública federal.

Considerando a importância dos recursos administrativos para a realização do direito de petição (art. 5. ${ }^{\circ}, \mathrm{XXXIV}, a \mathrm{CF} / 88$ ) e para o controle administrativo, essa revisão normativa será desempenhada com foco na análise das garantias recursais previstas nas legislações administrativas federais escolhidas.

Portanto, o objetivo dessa pesquisa acadêmica é determinar se as legislações administrativas federais incorporaram as garantias recursais constitucionalmente previstas de modo a possibilitar ao cidadão sua participação no processo decisório dos entes públicos federais.

Com o propósito de se atingir os objetivos estabelecidos para essa pesquisa acadêmica, o trabalho dissertativo foi dividido em três capítulos e as considerações finais.

O primeiro capítulo possui como finalidade a identificação dos elementos fundamentadores dos recursos administrativos na legislação brasileira. Primeiramente, é desenvolvida uma análise do tratamento dispensado ao processo administrativo nas constituições brasileiras, buscando-se compreender a abordagem constitucional utilizada em cada período histórico e as consequências dessa abordagem para a aplicação do processo administrativo no âmbito da Administração Pública. Por meio desse exame das constituições brasileiras, verificou-se quais garantias eram constitucionalmente previstas e o impacto dessa previsão na elaboração de normas processuais infraconstitucionais. A evolução histórica do tratamento do processo administrativo sob a perspectiva das constituições brasileiras encerra-se no diagnóstico dos direitos e garantias estabelecidos pela $\mathrm{CF} / 88$, desenvolvido por meio do estudo do fenômeno de constitucionalização das 
garantias processuais do devido processo legal administrativo, contraditório e ampla defesa e demais princípios administrativos pela $\mathrm{CF} / 88$. Considerando-se o impacto das mudanças decorrentes da constitucionalização das garantias processuais administrativas pela $\mathrm{CF} / 88$, é desenvolvida a interpretação dos efeitos e consequências da ausência de uma legislação federal sobre processo administrativo no período de 1988 a 1999, analisando-se os impactos dessa ausência na pesquisa acadêmica e na judicialização das questões administrativas.

Estabelecidos os aspectos históricos constituintes da lógica processual administrativa brasileira contemporânea, o estudo direciona-se à determinação dos pressupostos conceituais dos recursos administrativos. Assim, é desenvolvida a conceituação da natureza jurídica da Lei Federal n. 9.784/99 e o seu estabelecimento como paradigma normativo dessa pesquisa. Finalmente, considerando-se esses elementos trazidos pela CF/88 e pela Lei Federal n. 9.784/99, passa-se a verificação dos princípios e regras instrumentalizadores dos recursos administrativos e ao exame aprofundado do devido processo legal administrativo e do direito de recorrer.

O segundo capítulo consiste na elaboração de uma tipologia dos recursos administrativos segundo a Lei Federal n. 9.784/99. Inicialmente, o estudo desenvolve-se no sentido da identificação, definição e caracterização das espécies recursais previstas pela Lei Federal n. 9.784/99. Definidas as espécies de recursos administrativos, são analisadas as regras para cabimento, recebimento, processamento, julgamento, legitimidade, competência, prazos e efeitos desses recursos no processo administrativo dos entes públicos federais. Finalizando o capítulo, são verificadas os tipos de decisões recursais e os possíveis efeitos resultantes dessas decisões.

O terceiro capítulo compreende a análise das legislações federais escolhidas por meio da identificação dos dispositivos normativos cujo objetivo busque disciplinar aspectos relacionados com os recursos administrativos. Primeiramente, são traçados os aspectos históricos mais relevantes de cada legislação para caracterizá-las dentro do escopo da pesquisa. Em seguida, cada legislação é examinada quanto à existência de normas recursais e a extensão das garantias por elas previstas, considerando-se o paradigma estabelecido nos capítulos anteriores. Finalmente, é elaborado um diagnóstico das garantias recursais na legislação considerada tendo como base os pressupostos estabelecidos nos capítulos anteriores. 
Nas considerações finais são apresentadas as conclusões do trabalho e algumas propostas para o encaminhamento de trabalhos futuros que servirão para dar continuidade às pesquisas nesta área e melhorar, cada vez mais, os modelos aqui apresentados. 


\title{
ASPECTOS HISTÓRICOS E CONCEITUAIS DO PROCESSO ADMINISTRATIVO: DIÁLOGO COM O SISTEMA RECURSAL
}

\begin{abstract}
SUMÁRIO: 1. Evolução histórica do processo administrativo no ordenamento jurídico brasileiro; 1.1. As etapas evolutivas do processo administrativo; 1.2. A Lei Federal n. 9.784/99; 1.2.1. Contextualização: a constitucionalização do processo administrativo e as consequências da inexistência de uma lei geral; 1.2.2. Processo de elaboração da Lei Federal n. 9.784/99; 1.2.3. Aplicação da Lei Federal n. 9.784/99: norma básica ou norma geral - 2. Análise dos pressupostos dos recursos administrativos: 2.1. Definição de recurso administrativo; 2.2. Devido processo legal administrativo; 2.3. Recorribilidade das decisões administrativas; 2.4. A questão do duplo grau de jurisdição na esfera administrativa; 2.5. Considerações acerca dos pressupostos dos recursos administrativos; 2.6. A confiabilidade das soluções administrativas: peticionar ao Judiciário é mais eficaz do que os recursos administrativos? - 3. Considerações finais sobre os aspectos históricos e conceituais do processo administrativo.
\end{abstract}

O sistema recursal administrativo é uma ferramenta didática, não configurando, portanto, um instrumento autônomo de direito administrativo. Trata-se, pois, da denominação dada ao conjunto de regras encontradas na legislação de processo administrativo, cujo conteúdo esteja relacionado com aspectos instrumentalizadores do direito de recorrer. Em outras palavras, há uma relação de dependência entre o sistema recursal e o processo administrativo.

Nessa primeira parte do trabalho, são apresentados os principais aspectos históricos e conceituais que moldaram o processo administrativo brasileiro e influenciaram diretamente na formação de um sistema recursal administrativo. Assim, são analisadas as etapas evolutivas do processo administrativo dentro da perspectiva constitucional brasileira e do processo de elaboração da lei federal de processo administrativo. Além disso, são estabelecidos os pressupostos principiológicos dos recursos administrativos e examinadas as diversas questões decorrentes desses pressupostos.

\section{Evolução histórica do processo administrativo no ordenamento jurídico brasileiro}

A descrição analítica do histórico do processo administrativo brasileiro tem como finalidade examinar a contribuição das diversas legislações constitucionais e infraconstitucionais ao modelo normativo contemporâneo, tentando responder quais aspectos e dimensões vêm sendo destacados e privilegiados em decorrência do processo histórico experimentado pelo ordenamento jurídico brasileiro. 
Por questões metodológicas, a análise se restringirá ao período republicano, desconsiderando eventuais dispositivos normativos editados no período colonial ou no período imperial que ocupem-se de quaisquer questões relacionadas com a processualidade administrativa ${ }^{4}$.

O primeiro item, "As etapas evolutivas do processo administrativo", apresenta um mapeamento dos dispositivos constitucionais - nas constituições de 1891 a 1988 - que façam menção ao processo administrativo ou a órgãos cuja competência seja julgar atos administrativos. Além disso, identifica as legislações infraconstitucionais que tenham sido editadas com a finalidade de regular o processo administrativo nos entes públicos, procurando compreender os elementos envolvidos na escolha do modelo processual administrativo de determinado período.

Por sua vez, o item “A Lei Federal n. 9784/99” busca analisar três aspectos diferentes e complementares da legislação federal de processo administrativo. Primeiramente, descreve o fenômeno da constitucionalização do processo administrativo na $\mathrm{CF} / 88$ e as consequências da ausência de uma regulamentação desse dispositivo constitucional para a doutrina especializada em direito administrativo e a jurisprudência do Superior Tribunal Federal por um período de onze anos. Em seguida, ao revisitar a Nota Prévia redigida por Caio Tácito e encaminhada ao ministro da justiça Nelson A. Jobim, o item resgata o processo de elaboração da Lei Federal n. 9.784/99, examinando os temas e dispositivos normativos que orientaram as deliberações dos membros da comissão. Finalmente, é definido o âmbito espacial de aplicação da legislação federal de processo administrativo e outras características fundamentais da lei são apresentadas.

\subsection{As etapas evolutivas do processo administrativo}

A Constituição da República dos Estados Unidos do Brasil, de 24 de fevereiro de 1891, representou o rompimento com a ordem política e jurídica imperial, tendo estabelecido, por meio de um golpe militar, uma sólida base democrática fundamentada na (i) forma republicana de governo; no (ii) modelo federativo de Estado; e no (iii) princípio da separação dos poderes ${ }^{5}$. Embora outros projetos influenciados pelas

\footnotetext{
${ }^{4}$ Não será analisado, portanto, o período de dualidade de jurisdição com a presença do contencioso administrativo, marcadamente de inspiração francesa, que vigorou anteriormente ao período republicano. ${ }^{5}$ A Constituição de 1891 adotou o princípio de separação dos poderes conforme aperfeiçoamento do sistema de freios e contrapesos dos federalistas dos Estados Unidos da América (EUA), em que o poder judiciário assumiria o controle judicial das normas editadas pelo poder legislativo (HAMILTON, MADISON, JAY, 1984, pp.417,421).
} 
constituições da Argentina, Alemanha e Suíça tenham sido levados à apreciação da Assembleia Constituinte, foi o projeto idealizado por Ruy Barbosa de Oliveira e apresentado pelo Governo Provisório, notadamente inspirado pela Constituição dos Estados Unidos da América, que serviu de base para a elaboração da constituição republicana. Assim, o texto constitucional adotou a unicidade de jurisdição, afastando-se do modelo francês de contencioso administrativo (LEITE, 2003, p.107). Dessa maneira, o art. 60 dessa constituição estabelecia que caberia aos juízes e Tribunais Federais processar e julgar: (i) todas as causas propostas contra o Governo da União ou Fazenda Nacional, fundadas em disposições da Constituição, leis e regulamentos do Poder Executivo, ou em contratos celebrados com o mesmo Governo; (ii) as causas provenientes de compensações, reivindicações, indenização de prejuízos ou quaisquer outras propostas, pelo Governo da União contra particulares ou vice-versa; e (iii) os litígios entre um Estado e cidadãos de outro, ou entre cidadãos de Estados diversos, diversificando as leis destes (LEITE, 2003, pp.136-137). Há, portanto, submissão das matérias administrativas ao controle do poder judiciário.

O primeiro dispositivo normativo que regulamentou o processo administrativo no ordenamento jurídico brasileiro de que se tem registro é o art. 79 da Constituição da República dos Estados Unidos do Brasil, de 16 de julho de 1934:

Art. 79 - É criado um Tribunal, cuja denominação e organização a lei estabelecerá, composto de Juízes, nomeados pelo Presidente da República, na forma e com os requisitos determinados no art. 74 .

Parágrafo único - Competirá a esse Tribunal, nos termos que a lei estabelecer julgar privativa e definitivamente, salvo recurso voluntário para a Corte Suprema nas espécies que envolverem matéria constitucional:

$1^{\circ}$ ) os recursos de atos e decisões definitivas do Poder Executivo, e das sentenças dos Juízes federais nos litígios em que a União for parte, contanto que uns e outros digam respeito ao funcionamento de serviços públicos, ou se rejam, no todo ou em parte, pelo Direito Administrativo; 6

O objetivo da norma constitucional era a criação do Tribunal de Reclamações, cuja função seria julgar, em sede recursal, os atos administrativos emitidos pelo poder executivo, bem como as decisões de litígios envolvendo a União. Contudo, em razão da constituição não haver fixado prazo para sua instalação, o Tribunal de Reclamações nunca chegou a ser instalado, tendo ficado pendente da edição de norma infraconstitucional.

${ }^{6}$ BRASIL. Constituição da República dos Estados Unidos do Brasil, de 16 de julho de 1934. Disponível em < http://www.planalto.gov.br/ccivil_03/constituicao/constituicao34.htm>. Acesso em 26 ago 2014. 
Além da profunda preocupação com os atos administrativos do poder executivo e dos litígios envolvendo a União, materializado pelo art.79, o texto constitucional também incorporou uma relevante demanda apresentada pelos administrativistas da época: o processo administrativo disciplinar nas relações funcionais. $O$ art. 169 da Constituição de 1934 dispunha sobre a exigência de processo administrativo (ou judicial) para a aplicação da penalidade de demissão ao funcionário público (SUNDFELD, 2006, p.22).

A Constituição dos Estados Unidos do Brasil de 10 de novembro de $1937^{7}$, foi a quarta constituição da história brasileira. Elaborada pelo ministro da Justiça Francisco Luís da Silva Campos, essa constituição foi outorgada por Getúlio Vargas no mesmo dia em que, por meio de um golpe de Estado, era instaurada a ditadura do Estado Novo. Assim, tem-se que:

\begin{abstract}
A essência autoritária e centralista da Constituição de 1937 a colocava em sintonia com os modelos fascistizantes de organização político-institucional então em voga em diversas partes do mundo, rompendo com a tradição liberal dos textos constitucionais anteriormente vigentes no país. Sua principal característica era a enorme concentração de poderes nas mãos do chefe do Executivo. Do ponto de vista político-administrativo, seu conteúdo era fortemente centralizador, ficando a cargo do presidente da República a nomeação das autoridades estaduais, os interventores. Aos interventores, por seu turno, cabia nomear as autoridades municipais. (CPDOC, 1997)
\end{abstract}

A incorporação dessa ideologia ao texto constitucional revela consequências importantes para a processualidade administrativa. O art. 156, alínea $c$, da Constituição de 1937, é o primeiro dispositivo constitucional a introduzir a expressão "processo administrativo" como instrumento da atividade estatal, ao determinar que "os funcionários públicos [...] só poderão ser exonerados em virtude de sentença judiciária ou mediante processo administrativo, em que sejam ouvidos e possam defender-se”. A norma constitucional estipulava que a penalidade de exoneração somente poderia ser aplicada ao funcionário público por meio de processo administrativo (ou judicial), desde que fosse atendido o devido processo legal, materializado pelo contraditório e pela ampla defesa. Assim, o Decreto-lei n.1.713/1939 ${ }^{8}$, conhecido como Estatuto dos Funcionários Públicos Civis da União, fundamentado no texto constitucional, regulamentou, em seu Capítulo IV, o processo administrativo disciplinar.

${ }^{7}$ BRASIL. Constituição da República dos Estados Unidos do Brasil, de 10 de novembro de 1937. Disponível em < http://www.planalto.gov.br/ccivil_03/constituicao/constituicao37.htm>. Acesso em 26 ago 2014.

${ }^{8}$ BRASIL. Decreto-lei n.1.713, de 28 de outubro de 1939. Disponível em < http://www.planalto.gov.br/ccivil_03/decreto-lei/1937-1946/Del1713.htm>. Acesso em 26 ago 2014 
A Constituição dos Estados Unidos do Brasil, de 18 de setembro de $1946^{9}$, representou uma retomada dos valores democráticos, consagrando diversas liberdades individuais que haviam sido suprimidas pela constituição anterior. Há o reestabelecimento da separação dos poderes, tendo a Assembleia Constituinte elaborado "um texto preocupado fundamentalmente em delimitar o raio de ação dos poderes Executivo, Legislativo e Judiciário, para evitar uma nova experiência política baseada no poder discricionário do Executivo" (CPDOC, 2004). Quanto ao processo administrativo, a Constituição de 1946 determinou a criação do Tribunal Federal de Recursos, órgão vinculado ao poder judiciário (art.94, II), ao qual competiria o julgamento, em grau recursal, das causas em primeira instância em que a União fosse interessada como autora, ré, assistente ou opoente (art.104, II). Ainda, o art. 127 e o art.189, II, retomando mandamentos da constituição anterior, definiam que a demissão de membros do Ministério Público e funcionários públicos, respectivamente, deveria ser aplicada mediante processo administrativo (ou judicial), desde que respeitado o devido processo legal.

Seguindo tendência doutrinária da época ${ }^{10}$, o Conselho Administrativo da Caixa Econômica Federal do Paraná aprovou, em $1^{\circ}$ de dezembro de 1951, o projeto-plano de codificação, cuja finalidade era a simplificação das medidas processuais e a diminuição dos trâmites procedimentais em conformidade com o costume administrativo daquele período (FRANCO SOBRINHO, 1971, p.64). O projeto-plano adotou o seguinte sumário:

\footnotetext{
Capítulo I - Do Processo Administrativo em Geral; Capítulo II - Do Direito de Petição e da Proposta; Capítulo III - Dos Prazos de Curso Processual e das Intimações; Capítulo IV - Do Inquérito Administrativo; Capítulo V - Dos Recursos em Geral; Capítulo VI - Do Inquérito Administrativo; Capítulo VII - Da Documentação; Capítulo VIII - Das Avaliações; Capítulo IX - Das Operações e da Competência; Capítulo X - Do Procedimento Administrativo nos Empréstimos Hipotecários em Geral; Capítulo XI - Do Processo de Empréstimos sob Consignação; Capítulo XII Do Processo de Empréstimos sob Hipoteca aos Funcionários Públicos; Capítulo XIII - Do Processo de Empréstimo sob Caução; Capítulo XIV - Do Processo de Depósito em Custódia; Capítulo XV - Do Processo de Financiamento; Capítulo XVI - Do Processo de Despesa; Capítulo XVII - Do Processo de Concorrência; Capítulo XVIII - Do Processo de Publicidade; Capítulo XIX - Do Processo de Compromisso de Compra e Venda; Capítulo XX - Da Prisão Administrativa; Capítulo XXI - Do Modo do Proceder nas Agências do Interior; Capítulo XXII - Disposições Finais. (FRANCO SOBRINHO, 1971, p.63)
}

${ }^{9}$ BRASIL. Constituição da República dos Estados Unidos do Brasil, de 18 de setembro de 1946. Disponível em < http://www.planalto.gov.br/ccivil_03/constituicao/constituicao46.htm>. Acesso em 26 ago 2014.

${ }^{10}$ Cf. CAVALCANTI, Themístocles Brandão. A unificação das normas do processo administrativo. Arquivos do Ministério da Justiça, v. 33, n. 139, p. 1-31, jul./set., 1976 e FRANCO SOBRINHO, Manoel de Oliveira. Organização e sistema do processo administrativo. CEPF, Curitiba, 1952. 
Além disso, outras tentativas também foram feitas na Câmara dos Deputados no sentido de consolidar normas sobre o inquérito administrativo e os recursos administrativos, como resposta às reivindicações da realidade fática e do pensamento jurídico daquela época. Contudo, o legislativo brasileiro não estava "preparado para receber e completar um trabalho de unidade, tão grande se faziam os interêsses locais, tão enormes eram os interêsses da política sectária, tão demorados os trabalhos de aferição do mérito dos projetos e das proposições apresentadas" (FRANCO SOBRINHO, 1971, p.64). Em junho de 1956, o deputado federal Manoel de Oliveira Franco Sobrinho (PSD/PR) apresentou dois projetos de lei: (i) o Projeto de Lei n. 1.419/1956 ${ }^{11}$, que pretendia regular as normas gerais de procedimento no inquérito administrativo e (ii) o Projeto de Lei n. $1.491 / 1956^{12}$, cujo objetivo era regular o procedimento normativo no recurso administrativo. Ambos projetos foram arquivados.

Havia naquele período uma forte tendência a codificação que buscava a uniformidade das normas de processo administrativo, especialmente quanto aos inquéritos e sindicâncias, com a finalidade de assegurar o direito a defesa dos funcionários públicos (CAVALCANTI, 1976). Em um estudo sobre a codificação do Direito Administrativo, BARROS JÚNIOR (1949) explica que o agrupamento racional e prático das normas administrativistas tinha como princípio (i) reduzir as arbitrariedades no exercício da atividade administrativa, (ii) atender as necessidades práticas e (iii) tornar o exercício da atividade administrativa mais eficiente. Por sua vez, FRANCO SOBRINHO afirma que a importância da codificação do processo administrativo corresponderá "a um todo orgânico que tornará o Direito Administrativo tão característico quanto o Direito Civil" (1971, p.66).

Houve ainda outra legislação que merece ser analisada, em função do grande avanço que representou para a processualidade administrativa. A Lei n. 5.172/1966, conhecida como Código Tributário Nacional (CTN), representou profunda modificação nas relações processuais administrativas, pois, ao disciplinar o lançamento tributário, fez "sucessivas referências a conceitos e aspectos processuais, quando tratou da tomada de

\footnotetext{
${ }^{11}$ FRANCO SOBRINHO, Manoel de Oliveira. Projeto de Lei n.1.419 de 07 de junho de 1956. Disponível em < http://www.camara.gov.br/proposicoesWeb/fichadetramitacao?idProposicao=191889>. Acesso em: 26 ago 2014.

${ }^{12}$ FRANCO SOBRINHO, Manoel de Oliveira. Projeto de Lei n.1.491 de 25 de junho de 1956. Disponível em < http://www.camara.gov.br/proposicoesWeb/fichadetramitacao?idProposicao=192788>. Acesso em: 26 ago 2014
} 
decisão, de sua suspensão, revisão, etc. (veja-se, especialmente, os arts. 142 a 151)" (SUNDFELD, 2006, p.22).

A Constituição da República Federativa do Brasil, de 24 de janeiro de $1967^{13}$, com o objetivo de institucionalizar o regime militar, retoma o modelo utilizado anteriormente, em que aumenta a influência do poder executivo sobre o legislativo e o judiciário, de modo a instituir uma hierarquia constitucional centralizadora. São três os dispositivos constitucionais que se relacionam com a processualidade administrativa: (i) o art. 103, II, que definiu que a aplicação da penalidade de demissão do funcionário público estável somente poderia ocorrer mediante processo administrativo (ou judicial), desde que respeitada a ampla defesa; (ii) o art. 107, II, parágrafo único instituiu que a competência originária para anular atos administrativos de natureza tributária seria dos Tribunais Federais de Recursos; e (iii) o art. 138, $§ 1^{\circ}$ estabeleceu que a aplicação da penalidade de demissão dos membros do Ministério Público somente poderia ocorrer mediante processo administrativo (ou judicial), desde que respeitada a ampla defesa.

A necessidade de reconstrução da democracia e da instituição da cidadania no país impulsionou, ao longo das décadas de 1970 e 1980, a concepção de uma nova constituição, possibilitando, assim, o rompimento com a ditadura militar que assumira o governo brasileiro. Nesse sentido, diversos grupos da sociedade civil passavam a adotar uma postura contrária à ilegitimidade da Constituição de 1967, surgindo a demanda por um texto constitucional que representasse ideais e valores antagônicos aos instituídos pela ditadura (VERSIANI, 2010, pp. 235-240).

O processo constituinte contou com a intensa mobilização de diferentes setores sociais, sendo permeado por inúmeros embates políticos pela afirmação de direitos e ampliação da cidadania. Dessa maneira, a principal preocupação da assembleia constituinte foi a incorporação de instrumentos jurídicos que expandissem a participação popular na tomada de decisão do Poder Público (VERSIANI, 2010, p. 244).

A Constituição da República Federativa do Brasil, de 05 de outubro de 1988 (CF/88), "é precursora de significativas alterações no tratamento litúrgico até então outorgado aos processos ou procedimentos afetos às matérias reguladas pelo Direito Administrativo" (BACELLAR FILHO, 2006, p.13) ${ }^{14}$. Não obstante essa significativa

\footnotetext{
13 BRASIL. Constituição da República Federativa do Brasil de 1967, de 24 de janeiro de 1967. Disponível em < http://www.planalto.gov.br/ccivil_03/constituicao/constituicao67.htm>. Acesso em 26 ago 2014.

${ }^{14}$ Segundo RAMOS, “[e]m face da significativa extensão da normatividade constitucional sobre matéria de Direito Administrativo, é fácil compreender porque foi esse, entre os demais setores da Dogmática, o que
} 
conquista, destaca-se igualmente o reconhecimento da condição de cidadão do administrado, "[s]ujeito ativo na cena política, sujeito reivindicante ou provocador da mutação do direito [...]. O cidadão é o sujeito reivindicante possibilitador, na linguagem de LEFORT, da floração contínua de direitos novos" (CLÈVE, 1990, p.81).

Enquanto o art. 37 institui o regime jurídico constitucional-administrativo, orientado pelos princípios da legalidade, impessoalidade, moralidade, publicidade e eficiência, o art. $5^{\circ}$, LV fixa a existência de um núcleo mínimo de processualidade. Tratase, portanto, do estabelecimento de uma Administração Pública fundamentada no princípio da dignidade da pessoa humana e na garantia ao devido processo legal, materializado pela ampla defesa e pelo contraditório (BACELLAR FILHO, 2006, p.15).

O processo administrativo evoluiu de um instrumento meramente protetivo dos funcionários públicos para uma garantia a vedação da arbitrariedade no exercício da função administrativa pela autoridade (PEREIRA JÚNIOR, 1991, p.45).

\subsection{A Lei Federal n. 9.784/99}

Em razão da mudança de perspectiva estabelecida pela $\mathrm{CF} / 88$ quanto ao tratamento do processo administrativo, houve o surgimento da necessidade da elaboração de uma legislação infraconstitucional que consolidasse e regulamentasse os princípios e regras processuais administrativos determinados pelo art. $5^{\circ}, \mathrm{LV}$ e art. 37.

Em atendimento a essa demanda, foi elaborada a Lei Federal n. 9.784/99, legislação responsável pelo estabelecimento das normas gerais de processo administrativo federal.

\subsubsection{Contextualização: a constitucionalização do processo administrativo e as consequências da inexistência de uma lei geral.}

Ainda que a constitucionalização do direito de petição (art. 5, XXXIV CF/88) e do devido processo legal (art. $5^{\circ}, \mathrm{LV} \mathrm{CF} / 88$ ) tenha estabelecido o processo administrativo

mais repercutiu a sobredita reformulação constitucional do Estado brasileiro. Cumpre, entretanto, observar que, nos últimos anos, o dinamismo da produção doutrinária e jurisprudencial em relação aos temas do Direito Administrativo lhe rendeu a primazia no plano de renovação jurídica-científica nacional. Esse fenômeno se deve, de um lado, ao arrefecimento natural das discussões jurídico-constitucionais, na medida em que a Constituição de 1988 vai adquirindo longevidade, e, de outro lado, às inovações de cunho legislativo, infraconstitucional, que vêm se sucedendo nesse período. Inovações essas nem tanto decorrentes da necessidade de implementar princípios e normas constitucionais, mas, sobretudo, do amplo e ainda inacabado processo de reengenharia do Estado brasileiro que marcou a década de 90" (2006, p.76) 
como um direito fundamental dos cidadãos, diversas legislações estaduais com finalidade de regulamentação do processo administrativo tenham surgido após a promulgação da $\mathrm{CF} / 88$ e outras leis federais tenham abordado aspectos específicos do processo administrativo - i.e. Lei Federal n. 8.112/90 (Lei do servidor público federal) e Lei Federal n. 8.666/93 (Lei de licitações e contratos administrativos) - somente em 29 de janeiro de 1999 é que ocorreu a edição de uma lei geral com o objetivo de regulamentar o processo administrativo no âmbito federal, a Lei Federal n. 9.784/99 (Lei do processo administrativo federal $)^{15}$.

$\mathrm{O}$ reconhecimento constitucional do processo administrativo (art. $5^{\circ}, \mathrm{LV}$ da $\mathrm{CF} / 88$ ) não foi suficiente para assegurar efetividade funcional ao devido processo legal administrativo, de modo que consolidou-se a chamada "autocracia burocrática" (FERRAZ; DALLARI, 2012, p.23), caraterizada por práticas autoritárias. Nesse sentido, MODESTO afirma que a função administrativa:

caminhava sem prazos, ao sabor dos humores dos agentes públicos, que dilatavam os procedimentos de acordo com as suas conveniências, sem atenção ao cidadão à coisa pública, diante da ausência de marcos legais gerais objetivos que permitissem caracterizar esse comportamento como abusivo ou desidioso. Os procedimentos existentes eram geralmente estabelecidos para finalidades específicas, conhecidos de poucos e auto-referidos, atendendo sobretudo às necessidades de documentação da burocracia. (2000, p.1)

Concretamente, era comum (i) a recusa em receber petições e recursos; (ii) a resistência em conceder vista aos autos, (iii) os indeferimentos imotivados; (iv) os atrasos injustificados em emitir decisão; (v) a obscuridade ou falta de procedimentos, entre outros. Ou seja, é marcadamente um período de violação às garantias constitucionais do processo administrativo e dos direitos dos cidadãos.

As consequências da inexistência de uma lei geral não se restringiram exclusivamente à área administrativa, sendo possível perceber repercussões também na

\footnotetext{
15 Segundo MODESTO, "Há várias décadas os estudiosos do direito administrativo brasileiro protestam contra a inexistência de uma lei de normas gerais de processo administrativo no país e denunciam o atraso da administração pública brasileira na matéria. O incremento da edição de leis sobre processo administrativo, em todo o mundo, nas três últimas décadas, tornou ainda mais visível essa lacuna do ordenamento jurídico brasileiro. Datam deste período, por exemplo, a edição ou a reforma das leis de processo administrativo da Argentina (1972), da Alemanha (1976), da Venezuela (1982), da Itália (1990), de Portugal (1991) e da Espanha (1992)" (2000, p.1). Alinhando-se a esse pensamento, FERRAZ e DALLARI afirmam que "é quase um escândalo que date de 1999 a primeira federal geral de processo administrativo! [...] A consequência dessa idiossincracia do direito administrativo brasileiro é por todos conhecida: a Administração sempre se considerou senhora e dona do processo administrativo, decidindo, a seu talante, quando e como instaurá-lo, seu iter, a dimensão da atividade dos administrados em seu bojo, sua publicidade ou reserva etc." (2012, p.23)
} 
área acadêmico-doutrinária e no âmbito do poder judiciário. Assim, tanto o aumento da produção de obras acadêmicas sobre o ato administrativo ${ }^{16}$, quanto o agravamento da crise do poder judiciário, podem ser consideradas como decorrências dessa situação.

$\mathrm{O}$ enfoque adotado pela teoria do direito administrativo modifica-se profundamente com a promulgação da $\mathrm{CF} / 88$, em decorrência da adoção de uma nova interpretação do sentido da legalidade da atividade administrativa ${ }^{17}$. Em outras palavras,

a grande marca do regime constitucional em vigor, menos pela literalidade da Constituição e mais pela vida que a prática institucional lhe dá - aqui compreendida a atuação dos poderes estatais e a percepção política dos indivíduos, particularmente, dos teóricos do direito - é o alargamento do sentido de legalidade, com a substituição, como centro de gravidade da questão, do binômio legalidade formal ou material, por um sentido axiológico, de base constitucional, a inspirar a legalidade.

E esse alargamento do sentido da legalidade, por óbvio, altera o modo de ser da justiciabilidade.

A ampliação das possibilidades de controle jurisdicional da administração é o principal vetor atual de evolução da teoria do direito administrativo. (ALMEIDA, 2013, p.348)

A expansão do sentido da legalidade possibilita às correntes ideológicas da teoria do direito administrativo ${ }^{18}$ o desenvolvimento de uma nova chave interpretativa que coloca em evidência o questionamento da premissa de limitação do poder judiciário para o exame do mérito dos atos administrativos. Assim, a legalidade expandida, que incorpora princípios constitucionais como a moralidade, a eficiência, a proporcionalidade e a razoabilidade, permite a flexibilização da demarcação dos espaços da legalidade e do mérito da atividade administrativa passível de controle jurisdicional, transferindo a divergência teórica dessas correntes ideológicas "para os critérios desse controle, ou seja, para os critérios ao alcance do órgão jurisdicional para aferir o cumprimento dessa nova legalidade" (ALMEIDA, 2013, p.406).

\footnotetext{
${ }^{16}$ Conforme FERRAZ e DALLARI "[s]intomático, sugestivo e explicativo, portanto, que os autores derramem páginas e tintas numerosas para o exame do ato administrativo, pouco se aplicando, contudo, senão recentemente, na problemática do processo administrativo... E note-se: desde 1988 o processo administrativo recebera consagração e reconhecimento expresso no maior dos patamares normativos!" (2012, p.23)

17 Nesse sentido, "o foco da divergência teórica, no período posterior a 1988, desloca-se para o macromodelo da justicialidade, em uma tensão entre a valorização liberal da decisão legislativa (aqui incluído o sentido de constitucional), tomada no plano geral e abstrato, versus a valorização estatizante da decisão jurisdicional tomada no plano individual e concreto. De rigor, a principal chave para a compreensão dessa mudança de foco é a Constituição de 1988" (ALMEIDA, 2013, p.348).

18 Há a corrente liberal, que ressalta o qualitativo subjetivista, relativo à preeminência dos direitos fundamentais, e a corrente estatizante, que salienta o qualitativo publicista, referente à supremacia do interesse público (ALMEIDA, 2013, p.405).
} 
Dessa forma, é possível perceber um aumento na produção de pesquisas acadêmicas de direito administrativo voltadas ao exame do ato administrativo inserido no contexto da legalidade expandida. Esse fato pode ser facilmente comprovado por meio de uma breve pesquisa bibliográfica inserindo-se a expressão "ato administrativo" na ferramenta de busca do Banco de Dados Bibliográficos da Universidade de São Paulo (DEDALUS).

Para o conjunto de palavras "ato administrativo" foram obtidos 140 (cento e quarenta) registros de obras disponíveis no acervo. Ordenando-se os resultados obtidos e levando-se em conta somente o período de 1988 a 2014, elaborou-se a seguinte tabela, que fundamenta esse fenômeno: 
MEADUAR, Odete.

HORBACH, Carlos Bastide.

MEDEIROS, Fábio Mauro de.

AMARAL, Antônio Carlos Cintra do.

CHAIB, Liana.

MARTINS, Ricardo Marcondes.

D’ABRIL, Alfredo Enéias Gonçalves.

FRANÇA, Vladimir da Rocha.

FREITAS, Ney José de.

OLIVEIRA, Régis Fernandes de.

NOHARA, Irene Patrícia.

ARAÚJO, Florivaldo Dutra de.

NOHARA, Irene Patrícia.

SANTOS NETO, João Antunes dos.

TALAMINI, Daniele Coutinho

ARAÚJO, Edmir Netto de.

MARTINS, Eliezer Pereira.

MIRANDA, Sandra Julien.

ARAÚJO, Edmir Netto de.

AMARAL, Antônio Carlos Cintra do.

DI PIETRO, Maria Sylvia Zanella.

DINAMARCO, Cândido Rangel.

GRAU, Eros Roberto

ARAÚJO, Edmir Netto de.

CRETELLA JUNIOR, José.

ZANCANER BRUMINI, Weida.

ATALIBA, Geraldo.

SUNDFELD, Carlos Ari.
Regime jurídico do ato administrativo: o conceito de ato administrativo.

Teoria das nulidades do ato administrativo.

Extinção do ato administrativo em razão da mudança de lei: decaimento.

Teoria do ato administrativo.

O princípio da proporcionalidade no controle do ato administrativo.

Efeitos dos vícios do ato administrativo.

Ato administrativo.

Estrutura e motivação do ato administrativo.

Ato administrativo: presunção de validade e a questão do ônus da prova.

Ato administrativo.

Limites à razoabilidade nos atos administrativos.

Motivação e controle do ato administrativo.

O motivo no ato administrativo.

Da anulação ex officio do ato administrativo.

Revogação do ato administrativo.

Convalidação do ato administrativo.

Responsabilidade do estado por dano decorrente de ato administrativo disciplinar inválido.

Do ato administrativo complexo.

Atos administrativos e recomposição da legalidade.

Ato administrativo, licitações e contratos administrativos.

Necessidade de motivação do ato de dispensa de servidor celetista - Processo PGE n. $97.827 / 87$.

Litisconsórcio necessário - controle jurisdicional do ato administrativo.

Liquidação e intervenção em instituição financeira. Anulação do ato administrativo complexo.

Da convalidação do ato administrativo ilegítimo.

Controle jurisdicional do ato administrativo.

Da convalidação e da invalidação dos atos administrativos.

Eficácia do ato administrativo - publicação.

Ato administrativo inválido.
2011

2010

2009

2008

2008

2008

2007

2007

2007

2007

2006

2005

2004

2004

2002

1999

1998

1998

1997

1996

1996

1996

1996

1993

1993

1993

199

1990

Tabela 01: Registros no sistema de busca da biblioteca da Faculdade de Direito da Universidade de São Paulo para a entrada "ato administrativo"

Fonte: DEDALUS, 2014. 
Os efeitos da prolongada demora em editar uma legislação processual administrativa geral ainda se fazem perceptíveis no âmbito do poder judiciário, pois a ausência de uma filtragem eficiente no contexto dos processos administrativos contribui com um aumento da demanda nos tribunais superiores e a consolidação da cultura de recorribilidade por meio do processo judicial.

A análise do comportamento dos processos que tramitam no Supremo Tribunal Federal comprova o resultado negativo do longo período de ausência de uma legislação geral no âmbito processual administrativo. Há dois dados extremamente importantes que fundamentam essa afirmação: (i) o "Poder Público, seja por meio de entidades da Administração Pública Direta e Indireta, seja por intermédio de entes políticos, está entre os principais litigantes do Supremo" (FALCÃO, et al., 2013, p.16) e (ii) "Direito Administrativo é o tema mais representativo na maior parte das unidades da federação" (FALCÃO, et al., 2013, p.18) ${ }^{19}$.

Figuram entre os "top litigantes" no Supremo Tribunal Federal, no período de 2000 a 2009, oito entidades da Administração Pública e uma empresa privada, identificando-se a Caixa Econômica Federal (CEF) e o Instituto Nacional de Seguridade Social (INSS) - entidades públicas submetidas a Lei Federal n. 9784/99 - como duas das entidades públicas com maior litigiosidade no Supremo Tribunal Federal no período considerado. Destaca-se, ainda, o fato de que a Telemar Norte Leste S/A, única empresa privada entre os "top litigantes", é uma empresa concessionária que presta um serviço público essencial (art. 10, VII, Lei n. 7.783/89).

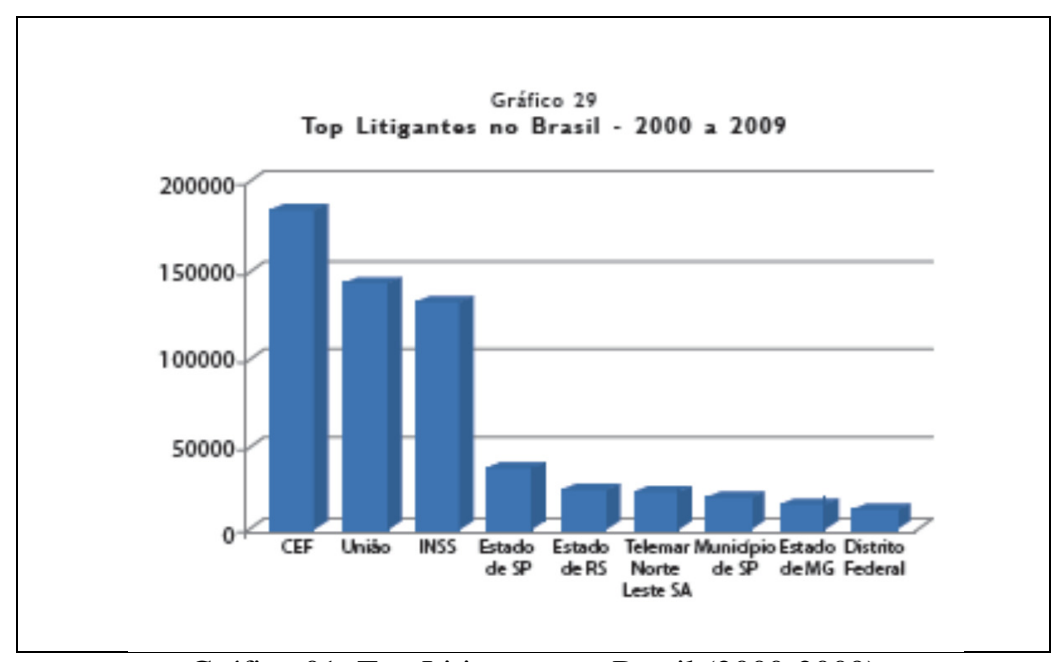

Gráfico 01: Top Litigantes no Brasil (2000-2009)

Fonte: SUPREMO EM NÚMEROS, 2013

\footnotetext{
${ }^{19}$ Ainda segundo o relatório do Supremo em Números, "entre os processos oriundos de juizado, os JEFs lideram em quase todas as unidades da federação" (2013, p.18), reafirmando a predileção por temas de direito público ou envolvendo o Poder Público.
} 
Dentre os temas mais recorrentes entre os processos que tramitam no Supremo Tribunal Federal, direito administrativo é o assunto do maior número de processos. Assim, da totalidade dos temas apresentados pelos processos, $21,7 \%$ estão relacionados com direito administrativo e outras matérias de direito público. Contudo, é importante destacar que mais da metade dos casos relacionados a direito administrativo referem-se a "servidor público" 20 , de modo que se essa categoria fosse separadamente considerada, "servidor público" seria o terceiro tema mais recorrente, enquanto que direito administrativo assumiria a quinta colocação (FALCÃO, et al., 2013, p.14).

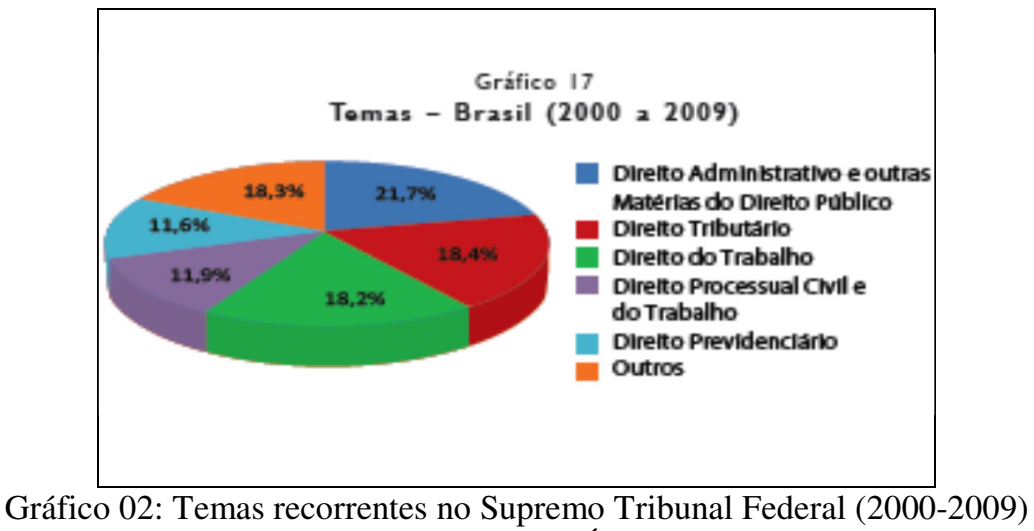

Fonte: SUPREMO EM NÚMEROS, 2013

O tratamento administrativo dos conflitos, filtro pré-processual de demandas, não tem eficientemente impedido que os litígios sejam encaminhados ao poder judiciário, vez que não há obrigatoriedade no exaurimento da instância administrativa ou na resolução extrajudicial de conflitos. Pode-se afirmar, também, que essa ampliação da procura por soluções judiciais para os conflitos administrativos é resultado da falta de uma definição mais explícita da relação entre a resolução administrativa e a judicial de conflitos, identificada por meio da ausência de um arranjo institucional entre o âmbito administrativo e o judicial.

Portanto, alternativas eficazes precisam ser desenvolvidas ou soluções existentes devem ser efetivadas para que se evite uma potencialização da litigiosidade judicial decorrentes de questões administrativas (GABBAY, CUNHA, 2012, p.153). Nesse contexto, destaca-se a essencial função desempenhada por uma legislação geral de processo administrativo na filtragem de demandas, por meio do estabelecimento de um

20 "Em 2009, a concentração de processos de servidores públicos estatutários no Supremo era 13 vezes maior que a de processos de trabalhadores com carteira assinada" (FALCÃO, et al.,, 2013, p.14) 
processo decisório confiável e eficaz, capaz de produzir decisões fundamentadas, justas, coerentes e plenamente sintonizadas com a realidade jurídica e social.

Tendo sido apresentadas as razões justificadoras para a criação de uma lei federal de processo administrativo no cenário jurídico brasileiro, torna-se importante examinar o processo de elaboração da Lei Federal n. 9.874/99.

\subsubsection{Processo de elaboração da Lei Federal n. 9.784/9921}

Por meio da Portaria n. 1404, de 17 de outubro de 1995, o Ministério da Justiça criou a comissão para elaboração de um projeto de lei sobre normas gerais de procedimento administrativo, composta preliminarmente por Caio Tácito $^{22}$, Odete Medauar, Maria Sylvia Zanella Di Pietro, Inocêncio Mártires Coelho, Diogo de Figueiredo Moreira Neto, Almiro Couto e Silva e José Carlos Barbosa Moreira. Após José Carlos Barbosa Moreira solicitar dispensa por motivos de ordem pessoal, a comissão foi reconstituída pela Portaria Interministerial n. 37, de 31 de janeiro de 1996, do Ministério da Justiça e do Ministério da Administração e Reforma do Estado, com a inclusão de novos membros, a saber: Adilson de Abreu Dallari, José Joaquim Calmon de Passos, Paulo Eduardo Garrido Modesto e Carmem Lúcia Antunes Rocha.

A comissão instituída pela Portaria n.37 reuniu-se em quatro diferentes oportunidades, que tomaram lugar nas cidades de Brasília, Rio de Janeiro e São Paulo. As deliberações adotadas nessas reuniões foram consolidadas por Odete Medauar em um único documento, o anteprojeto de lei, cujo texto final foi revisto e aprovado em 16 de agosto de 1996.

Na Nota Prévia encaminhada ao ministro da justiça, Nelson A. Jobim, Caio TÁCITO explica que a comissão orientou-se pelos incisos XXXIII, XXXIV e LV do art. $5^{\circ}$ da $\mathrm{CF} / 88$ - garantidores (i) da aplicação dos princípios do contraditório e da ampla defesa, (ii) do direito de recebimento de informações dos órgãos públicos em questões de interesse particular ou coletivo e (iii) da obtenção de certidões em repartições públicas nos processos administrativos - e pela necessidade de efetivação da participação popular na Administração Pública (1996, p.349).

\footnotetext{
${ }^{21}$ As informações históricas que compõe esse subitem foram extraídas da nota prévia ao texto de projeto de lei sobre normas gerais de procedimento administrativo encaminhado ao ministro da justiça Nelson A. Jobim, publicada nas páginas 349-350 da Revista de Direito Administrativo n. 205 de jul./set. de 1996.

${ }^{22}$ A Comissão foi presidida por Caio Tácito.
} 
Considerando que o ordenamento jurídico brasileiro apresenta regimes especiais para os processos tributários, licitatórios e disciplinares, a comissão teve como preocupação a elaboração de um projeto de lei que ressalvasse "a eficácia das leis especiais, com a aplicação subsidiária das normas gerais a serem editadas" (TÁCITO, 1996, p.349).

Além disso, em conformidade com o determinado pelo art. 37 da CF/88, o projeto de lei apresentado estabelecia a aplicação dos princípios da legalidade, impessoalidade, moralidade e publicidade ao processo administrativo, e também de outros princípios incorporados por força tanto da doutrina quanto da jurisprudência, como o da finalidade, razoabilidade, proporcionalidade, motivação, interesse público e segurança jurídica.

Conforme esclarece TÁCITO:

O projeto procura enunciar os critérios básicos a que se devem submeter os processos administrativos, em função dos indicados princípios, cuidando de definir direitos e deveres dos administrados, assim como o dever da Administração de decidir sobre as pretensões dos interessados. (1996, p.350)

A Lei Federal n. 9784/99 foi elaborada considerando-se um enfoque da função administrativa majoritariamente processual, com a previsão inclusive de recursos administrativos e revisão dos atos decisórios, além da estipulação dos mecanismos de contagem processual de prazos. Ainda, a legislação reforça o poder de anular, revogar e convalidar os atos administrativos e da possibilidade de delegação e avocação de competência.

Em relação a essa procedimentalização da função administrativa, TÁCITO ressalta que:

Adotou a comissão, como regra, o modelo de uma lei sóbria que, atendendo à essencialidade na regulação dos pontos fundamentais do procedimento administrativo, não inviabilize a flexibilidade necessária à área criativa do poder discricionário em medida compatível com a garantia de direitos e liberdades fundamentais. (1996, p.350).

Por esse motivo, a legislação federal de processo administrativo deve ser considerada referência para a atuação administrativa, pois procura compatibilizar a 
processualidade - muitas vezes sinônimo de segurança jurídica - com a eficiência necessária para dar vazão as demandas da Administração Pública ${ }^{23}$.

O projeto de lei foi aprovado em 29 de janeiro de 1999, tendo sido referendado pelo Ministério do Orçamento e Gestão do governo Fernando Henrique Cardoso. A publicação da Lei Federal n. 9784/99 no Diário Oficial da União foi em 01 de fevereiro de 1999, com a seguinte ementa: "regula o processo administrativo no âmbito da administração pública federal”.

\subsubsection{Aplicação da Lei Federal n. 9.784/99: norma básica ou norma geral}

Considerando que as normas de processo administrativo possibilitaram a limitação do poder da autoridade a vedação da prática de arbitrariedades na tomada de decisões, a existência de focos de resistência em diversos setores da Administração Pública na aplicação da Lei Federal n. 9.784/99 pode ser explicada como uma tentativa de preservação da concepção patrimonialista e autoritária anteriormente vigente na atuação administrativa (FERRAZ; DALLARI, 2012, p. 40). Se há uma relutância na aplicação da legislação federal de processo administrativo, torna-se essencial entender (e desmistificar) os obstáculos eleitos como óbice a essa aplicação.

Por meio do art. $1^{\circ}$ da Lei Federal n. 9.784/99, o legislador federal determinou que a lei de processo administrativo adotaria um caráter de norma básica de processo administrativo. Haja vista ser habitual a confusão entre as terminologias norma básica e norma geral, há que se recorrer a uma breve diferenciação entre ambas as espécies normativas para se estabelecer a finalidade buscada pelo legislador com a edição da Lei Federal n. 9.784/99.

As normas gerais são regras uniformizadoras de questões genéricas pertinentes a todos os entes federativos, motivo pelo qual o objeto das normas gerais não deve ser desenvolvido de maneira exaustiva ou detalhada, sob pena de esvaziar ou extrapolar os limites impostos pelas competências concorrentes de cada ente federativo. Em razão do seu caráter generalista e de conexão dos entes federativos, as normas gerais são vigentes em todo o território nacional e de observância obrigatória por parte da União, Estados e Municípios. Além disso, a outorga de competência exclusiva ao poder central para a

\footnotetext{
23 "O contato cotidiano entre Administração e administrado nada mais é que o processo administrativo: palco da vivência diária do poder e, por isso, uma ferramenta essencial na construção e manutenção do projeto de Estado Democrático do Direito" (GUEDES, 2007, p.146)
} 
edição de normas gerais relaciona-se justamente com sua vocação uniformizadora de aspectos gerais, centrais e essenciais à dinâmica dos entes federativos.

É nesse sentido que GUIMARÃES explica que:

[N]orma geral não é equiparável a norma-princípio, isto é: não tem por conteúdo necessariamente a veiculação de princípios e diretrizes. Melhor é referir a uma disciplina de base como conteúdo das normas gerais, própria a regular aspectos essenciais e centrais de certa matéria, deixando-se (como regra) margem para a disciplina de assuntos periféricos pelos demais entes federados. Limita-se a esfera de competência legislativa das normas às matérias consideradas centrais, essenciais e gerais acerca de certo campo temático, extrapolado quando se adentra na regulação de questões periféricas, que descem a detalhamentos e minudências alusivas à situação regional ou local $(2009$, p.6)

Portanto, norma geral deve ser compreendida como um desenho genérico de uma determinada questão, com uma função uniformizadora do tema, de modo a permitir que cada ente federativo, fundamentado em suas próprias circunstâncias, vocações e características, coloque em exercício sua competência concorrente para editar normas específicas sobre esse mesmo tema.

Básica - etimologicamente derivada da palavra base, que significa "tudo quanto serve de fundamento ou apoio" (FERREIRA, 2006, p.168) - é a característica daquilo que dá suporte a outra coisa. As normas básicas são aquelas que "não são as únicas regras incidentes, mas as que devem ser aplicadas com prevalência sobre quaisquer outras" (CARVALHO FILHO, 2013, p. 34), pois servem como alicerce para o exercício de determinado direito.

Diferentemente das normas gerais, as normas básicas estabelecem princípios e regras (diretrizes) elementares para a realização de um direito, podendo, dessa forma, tanto suplementar normas específicas quanto aplicar-se integralmente em razão da situação.

Além disso, tem-se que:

[E]ntre as normas básicas da lei pode haver, sem qualquer questionamento de inconstitucionalidade, tanto regramentos com maior grau de generalidade (como princípios e regras de conteúdo abrangente) quanto dispositivos que regulam minúcias ou especificidades, como o estabelecimento de prazos para a prática de certos atos. (MARRARA; NOHARA, 2009, p.27)

Assim, enquanto as normas gerais possuem um caráter uniformizador, as normas básicas adotam uma perspectiva de elementaridade. A consequência lógica dessa 
característica é que as normas básicas não possuem incidência nacional e são de competência do respectivo ente federativo.

Um último aspecto importante das normas básicas é que elas permitem uma certa margem de liberdade no exercício da função administrativa - especialmente naquilo que concerne às rotinas administrativas - desde que considerados o interesse público e a finalidade da atuação administrativa (CARVALHO FILHO, 2013, p. 35).

A Lei Federal n. 9.784/99, ao se autoproclamar uma norma básica de processo administrativo, cumpre a finalidade de orientar a função administrativa, garantindo ao cidadão a efetivação do devido processo legal administrativo, sendo, portanto, integralmente aplicada quando se tratar de processo administrativo no âmbito federal (FORTINI; PEREIRA; CAMARÃO, 2012, p.31). Além disso, o art. 69 da Lei Federal n. 9.784/99 reforça que, diante da existência de norma específica de processo administrativo, a Lei Federal n. 9.784/99 será aplicada subsidiariamente, com prevalência de suas normas quando a legislação específica ofender as diretrizes por ela ou constitucionalmente determinadas (CARVALHO FILHO, 2013, p. 35).

Resumindo esse entendimento, Celso Antônio Bandeira de MELLO enfatiza que:

É importante anotar que a lei em causa aplica-se apenas subsidiariamente aos processos administrativos específicos, regidos por leis próprias, que a elas continuarão sujeitos. Como é lógico, aplica-se integralmente a quaisquer outros processos administrativos (2008, p.502)

Em relação a sua incidência, o art. $1^{\text {o }}$ da Lei Federal n. 9.784/99 estabelece que as normas básicas de processo administrativo aplicar-se-ão a toda a administração federal direta e indireta. Ainda, deve-se considerar que a Lei Federal n. 9.784/99 também incidirá nos processos administrativos desenvolvidos pelo poder legislativo e pelo poder judiciário, quando esses poderes estiverem desempenhando a função administrativa atipicamente ${ }^{24}$.

Por fim, enquanto a Lei Federal n. 9.784/99 aplica-se integralmente aos processos administrativos federais genéricos, no caso dos processos federais específicos a legislação federal deverá ser aplicada subsidiariamente, conforme previsão de seu art. 69.

Encerrada a análise dos aspectos históricos formadores do processo administrativo brasileiro, essa pesquisa volta-se ao exame dos pressupostos conceituais fundamentadores

\footnotetext{
${ }^{24}$ Os demais entes federativos possuem autonomia para legislar quanto a regras processuais administrativas, contudo, por força do art. 69 da Lei Federal n. 9.784/99, poderá a legislação federal ser aplicada subsidiariamente sempre que necessário.
} 
dos recursos administrativos segundo a lógica da legislação de processo administrativo federal.

\section{Análise dos pressupostos dos recursos administrativos}

Previamente ao exame dos recursos administrativos conforme disciplinados pela Lei Federal n. 9784/99, é necessária a elaboração de uma análise dos pressupostos dos recursos administrativos.

O primeiro subitem procura apresentar uma conceituação para os recursos administrativos segundo a lógica do direito administrativo, bem como a delimitação de alguns de seus aspectos substanciais.

Em razão da importância do art. $5^{\circ}$, inciso $\mathrm{LV}$ da $\mathrm{CF} / 88$ para a processualidade administrativa, o segundo subitem procura desenvolver uma breve análise do devido processo legal e seus elementos componentes enquanto garantia constitucional do processo administrativo.

Ainda, o terceiro e o quarto subitens busca a caracterização e diferenciação do fenômeno da recorribilidade das decisões administrativas e da questão do duplo grau de jurisdição na esfera administrativa.

Como linha condutora e preparatória para o próximo capítulo, o quinto subitem terá como objetivo a apresentação de algumas considerações preliminares quanto aos pressupostos dos recursos administrativos anteriormente examinados.

Finalmente, o último subitem estabelece os fundamentos para o desenvolvimento do debate acerca do grau de confiabilidade das soluções no âmbito administrativo, numa tentativa de responder a questão da eficiência das decisões judiciais frente a opção pelo recurso na esfera administrativa.

\subsection{Definição de recurso administrativo}

Etimologicamente, recurso significa o restabelecimento do ponto de partida inicialmente adotado (recondução ao status quo ante). Recurso é, portanto, a possibilidade de se refazer o curso para "fazer desaparecer" a decisão desfavorável 
(JORGE, 2007, p.21), ou seja, o poder de provocar o reexame da decisão com a finalidade de se obter sua reforma ou modificação (SANTOS, 1980, p.117) ${ }^{25}$.

Os atos, incluindo-se entre eles os decisórios, são estruturados pela conjugação de dois elementos: (i) regras técnicas e (ii) regras éticas. As regras técnicas indicam os requisitos necessários para a produção de um ato voltado ao cumprimento de determinado objetivo e as regras éticas estabelecem as condições indispensáveis para que esse ato esteja em conformidade com os preceitos da justiça. Assim, enquanto as regras técnicas conferem conveniência, as regras éticas atribuem justiça ao ato, sendo que a associação da conveniência com a justiça é denominada de núcleo de legalidade do ato (NERY JUNIOR, 2004, p. 202). Portanto, atos viciados são todos aqueles desprovidos ou de conveniência ou de justiça, o que, consequentemente, ocasiona a ausência de legalidade nesse ato.

O recurso é o "meio processual colocado à disposição dos interessados para que seja eliminado o ato processual viciado ou para que seja adequada a sua legalidade à conveniência e justiça" (NERY JUNIOR, 2004, p. 203) ${ }^{26}$. Dessa forma, o recurso pode ser considerado um instrumento de controle dos atos viciados, cujo resultado pode ser: (i) a confirmação, que consiste na renúncia ao poder de anular o ato viciado; (ii) a convalidação, em que a autoridade decide que o vício existente deve ser suprido com feitos retroativos à sua prática; e (iii) a revogação, em que o ato válido é extinto por razões de oportunidade e conveniência (DI PIETRO, 2011, pp.248-252).

Na prática, o recurso possui uma função uniformizadora, pois permite "encontrar a real e correta interpretação a ser dada à norma, de modo que todos estejam sujeitos a ela de forma idêntica" (JORGE, 2007, p.28). Essa função uniformizadora consiste em um reforço à segurança jurídica das decisões, pois conduz a uma certa previsibilidade quanto à interpretação da norma jurídica por uma determinada autoridade.

Há, portanto, duas dimensões essenciais do recurso: (i) reexame da decisão com readequação quanto a sua legalidade e mérito e (ii) harmonização da decisão em relação ao interesse público consagrado pela norma jurídica, por meio da exclusão de interpretações inválidas.

\footnotetext{
25 A decisão em sede recursal poderá determinar a procedência ou improcedência do pedido trazido a julgamento. Dessa forma, somente nos casos em que houver acolhimento do pedido é que haverá reforma ou modificação da decisão anterior, sendo que na decisão pela improcedência do pedido, necessariamente, haverá confirmação da decisão anterior.

${ }^{26}$ NERY JUNIOR explica que "tanto o error in procedendo, que enseja a anulação da decisão, quanto o error in iudicando, causa de sua reforma, são corrigíveis por meio de recurso" (2004, p.208).
} 
O recurso pressupõe a existência de uma decisão prévia devidamente motivada e que tenha sido resultado de um processo conforme com o devido processo legal ${ }^{27}$. Assim, no que diz respeito a sua natureza jurídica, o recurso deve ser compreendido como uma extensão do processo original, pois a apresentação de recurso contra a decisão proferida não inicia uma nova relação processual entre as partes envolvidas, sendo meramente o prolongamento da relação iniciada no processo original (NERY JÚNIOR, 2004, p.206). O recurso, dessa forma, estabelece uma nova fase procedimental (JORGE, 2007, p.22), cuja finalidade é a reapreciação da decisão. Essa nova etapa é denominada de procedimento recursal (ALVIM NETTO, 1972, p.363) e inicia-se com a apresentação do recurso estendendo-se até a pronúncia da decisão recursal ${ }^{28}$.

Considerando que a processualidade não é um fenômeno restrito à função jurisdicional, é possível afirmar a existência de um núcleo comum de processualidade entre as diversas funções estatais (SUNDFELD, 1987, p.66-68). MEDAUAR explica que “[a] partir desse núcleo de identidade mínima, irradiam-se pontos de diversidade, em grande parte decorrentes das características da função que a processualidade traduz e do ato final a que tende" (1993, p.23). Dessa maneira, embora o recurso administrativo tenha essencialmente a mesma finalidade que o recurso judicial, admite-se algumas peculiaridades daquele em relação a esse.

Na via administrativa, o recurso é o meio pelo qual a “Administração é provocada a fiscalizar seus próprios atos, visando ao atendimento do interesse público e à preservação da legalidade" (MEDAUAR, 2010, p.398), o que significa que o recurso administrativo é um dos meios formais de controle administrativo para o reexame do ato administrativo. Diferentemente daquilo que ocorre em sede judicial, o recurso administrativo não configura meio de defesa exclusivo em processos litigiosos, vez que "há inúmeros processos não litigiosos em que o administrador pratica ato que contraria

\footnotetext{
${ }^{27}$ Não é difícil encontrar imprecisões terminológicas na legislação administrativa. O Código de Trânsito Brasileiro (Lei n. 9.503/1997), por diversas vezes, utiliza a palavra "recurso" como sinônimo de defesa ou contestação, como é o caso do art. $282, \S 4^{\circ}$, transcrito a seguir:

“Art. 282. Aplicada a penalidade, será expedida notificação ao proprietário do veículo ou ao infrator, por remessa postal ou por qualquer outro meio tecnológico hábil, que assegure a ciência da imposição da penalidade.

$\S 4^{\circ}$ Da notificação deverá constar a data do término do prazo para apresentação de recurso pelo responsável pela infração, que não será inferior a trinta dias contados da data da notificação da penalidade. (Incluído pela Lei n. 9.602/1998)."

${ }^{28}$ Segundo JORGE: “Até a prolação da sentença, existia apenas uma pretensão processual deduzida, que em razão das partes, daria ensejo a uma sentença homologatória dessa disposição de vontade. Entretanto, com a sentença e a consequente interposição do recurso, o ato de disposição não se volta a essa pretensão retratada na inicial, mas, sim, à pretensão tal como definida na sentença” (2007, p.23)
} 
interesse ou direito do administrado: é o caso, por exemplo, em que o interessado requer uma licença, ou pede seja adotada determinada providência" (CARVALHO FILHO, 2013, p.291).

Outro ponto relevante que individualiza o recurso administrativo é a possibilidade de produção de novas provas e a arguição de outros argumentos que não houvessem sido apresentados anteriormente, "já que ocorre uma devolução integral da matéria objeto do processo à nova autoridade competente para produzir nova decisão" (FERRAZ; DALLARI, 2012, p.296), em razão dos princípios da oficialidade, verdade material e eficiência.

Em relação aos princípios de observância obrigatória, listados pelo art. $2^{\circ}$ caput e parágrafo único da Lei n. 9.784/99, o procedimento recursal necessariamente deve ser desenvolvido em obediência ao princípio da legalidade, finalidade, motivação, razoabilidade, proporcionalidade, moralidade, ampla defesa e contraditório (devido processo legal), segurança jurídica, interesse público e eficiência, pois, conforme esclarecido anteriormente, representa simples prolongamento da relação processual inicialmente instaurada. O que vale para o processo administrativo vale igualmente para o recurso administrativo ${ }^{29}$.

\subsection{Devido processo legal administrativo}

O devido processo legal impõe duas espécies de limitação ao poder estatal: para privar o cidadão de seus direitos, i.e. vida, liberdade ou propriedade, o governo deve observar o substantive due process e o procedural due process (CHEMERINSKY, 2006, p.557). O devido processo substantivo orienta a produção legislativa para a criação de normas que possibilitem a realização dos direitos fundamentais nos diversos procedimentos, encerrando a ideia de um processo legal, justo e adequado quando a finalidade for legitimar o sacrifício da vida, liberdade ou propriedade dos cidadãos (CANOTILHO, 2003, p.494). Por sua vez, o devido processo legal procedimental é o conjunto dos requisitos formais que devem ser considerados antes que se proceda à privação destes direitos: (i) contraditório e ampla defesa; (ii) duplo grau de jurisdição;

\footnotetext{
${ }^{29}$ Conforme explica JORGE: “a disposição constitucional relativa aos 'recursos' deve ser vista em relação ao regular devido processo legal, de modo que não sejam permitidos abusos ou mesmo que se impossibilite às partes o controle das decisões (...), garantindo-se assim o direito à ampla defesa” (2007, p. 31)
} 
(iii) juiz natural e competente; (iv) proibição de prova ilicitamente obtida; (v) publicidade; (vi) imparcialidade; (vii) motivação (VIERA, 2006, pp. 480-481).

Não é nenhuma novidade que o devido processo legal é amplamente reconhecido pelas legislações de diversos países como um direito fundamental inalienável, tendo sido garantido pelo art. $8^{\circ}$ da Declaração Universal dos Direitos Humanos ${ }^{30}$ e o art. $8^{\circ}$ da Convenção Americana de Direitos Humanos (Pacto de San Jose da Costa Rica) ${ }^{31}$. No Brasil, A CF/88 determinou, por meio do art. $5^{\circ}$, inciso LIV, a observância do devido processo legal em todos os processos de privação de liberdade e de bens dos cidadãos ${ }^{32}$. Contudo, foi por meio do art. $5^{\circ}$, inciso LV que o legislador constitucional tornou definitivamente incontroversa a garantia do devido processo legal na atividade administrativa, quando estipulou que aos litigantes e acusados em processo administrativo será obrigatoriamente assegurada a ampla defesa e o contraditório.

Para a Administração Pública, o devido processo legal se apresenta como dois modos diferentes e concomitantes de proteção dos direitos dos cidadãos perante a atividade administrativa. O “devido processo legal administrativo” (GRINOVER, 1990, p.9) substancial garante ao cidadão a participação pública na produção do ato administrativo enquanto que o procedimental viabiliza o exercício da tutela administrativa, por meio do processo administrativo, nos casos em que a atividade administrativa acarrete violação dos direitos dos cidadãos (MONTEIRO, 2000, p.355). É, portanto, um princípio constitucional que aproxima direitos públicos subjetivos da sua persecução por meios processuais na esfera administrativa (CINTRA; GRINOVER; DINAMARCO, 2007, p.88) ${ }^{33}$.

\footnotetext{
${ }^{30}$ Art.8. Todo o homem tem direito a receber dos tribunais nacionais competentes remédio efetivo para os atos que violem os direitos fundamentais que lhe sejam reconhecidos pela constituição ou pela lei.

${ }^{31}$ Art. 8. Garantias judiciais

1. Toda pessoa terá o direito de ser ouvida, com as devidas garantias e dentro de um prazo razoável, por um juiz ou Tribunal competente, independente e imparcial, estabelecido anteriormente por lei, na apuração de qualquer acusação penal formulada contra ela, ou na determinação de seus direitos e obrigações de caráter civil, trabalhista, fiscal ou de qualquer outra natureza.

${ }^{32} \mathrm{O}$ texto constitucional não tinha a intenção de, com a expressão "privação de liberdades e bens", restringir a aplicação do devido processo legal somente a processos em que figurem "liberdade" e "bens" em sua acepção mais stricto sensu, devendo-se, desse modo, considerar esses termos em seu sentido mais amplo. Portanto, no caso da Administração Pública, o devido processo legal "deverá ser aplicad[o] frente a qualquer espécie de atuação administrativa (jurisdicionante ou não)” (MOREIRA, E. B., 2007, p.290)

${ }^{33}$ Segundo LUCON, “[o] devido processo legal objetiva também a limitação política do poder estatal como um todo, mediante uma série de condicionantes e restrições legítimas ao exercício das funções do Estado Moderno. Relativamente à jurisdição, tais limitações referem-se a situações substanciais e às formas dos atos, mediante o adequado processo legal, no qual o julgador deve fazer cumprir as normas constitucionais e infraconstitucionais, para que as partes tenham no processo administrativo ou judicial, tratamento paritário." (1998, p.101)
} 
O devido processo legal administrativo é uma das garantias constitucionais mais importantes da Administração Pública, pois dele decorre a aplicação de todos os outros princípios constitucionais e infraconstitucionais que orientam o exercício da função administrativa e garantem a efetiva tutela dos direitos e interesses individuais, coletivos e difusos envolvidos na atividade administrativa. Desse modo, a prática do ato administrativo vincula-se a realização dos parâmetros de legalidade, contraditório, ampla defesa, impessoalidade, razoabilidade, proporcionalidade, motivação, eficiência, publicidade e segurança jurídica como manifestações da cláusula genérica do devido processo legal administrativo ${ }^{34}$.

O processo administrativo é o espaço de realização do devido processo legal administrativo. Assim sendo, a Administração Pública possui o dever inafastável de instalar o adequado processo administrativo - tendo o devido processo legal como requisito obrigatório para sua regularidade - para "permitir que os indivíduos que poderão ser afetados pelo ato administrativo tenham oportunidade de exercer uma série de garantias processuais, as quais têm por escopo protegê-los da arbitrariedade da Administração Pública" (MELLO, R., 2002, p.91), ou seja, a instauração do processo administrativo ocorre por meio do ato administrativo inaugural, que estabelece uma série de deveres processuais obrigatórios a serem obedecidos pelos agentes públicos no exercício da função administrativa para a promoção das prerrogativas emanadas do devido processo legal administrativo (MOREIRA, E. B., 2007, p.279).

O devido processo legal administrativo não se confunde com a ampla defesa e o contraditório, pois configura um conjunto maior de elementos garantidores dos direitos fundamentais dos cidadãos, com a finalidade de legitimar a ação estatal na figura do agente público (ROCHA, 1997, p.5). Dessa maneira, não terá atendido ao devido processo legal, o processo administrativo que (i) for sigiloso; (ii) for excessivamente informal; (iii) for excessivamente formal; (iv) não houver participação efetiva do interessado ou acusado; (v) for desobediente ao procedimentos legalmente previstos; (vi) violador de princípios e garantias constitucionais e infraconstitucionais; (vii) que não persiga interesse público; (viii) que seja ineficiente; (ix) que seja ineficaz e (x) que não

\footnotetext{
${ }^{34} \mathrm{O}$ devido processo administrativo tem como consequência lógica a ampliação dos meios de controle da prática dos atos administrativos, pois possibilita a previsão dos parâmetros que devem balizar a função administrativa. Conforme GELLHORN e LEVIN: “[t]his constitutional doctrine gives federal courts a potent tool with which to oversee the decision making procedures of federal agencies when the applicable statutes and regulations permit the administrator to act informally. Equally important, the doctrine gives the federal judiciary a measure of control over the decision making methods of state and local agencies, which otherwise are governed almost exclusively by state law" (1997, p.191)
} 
possibilite a recorribilidade das decisões proferidas. Enfim, o processo administrativo somente será devido se não desatender aos aspectos inseridos na relação de dever-poder que caracteriza a atividade administrativa, de forma a não possibilitar ao agente público o afastamento da norma de onde emana sua competência e determina os fins a serem cumpridos pela Administração Pública (MOREIRA, E. B., 2007, p.282-283) ${ }^{35}$.

Essa é a essência primordial do devido processo legal administrativo, possibilitar o exercício da função administrativa dentro de determinados parâmetros préestabelecidos que ampliem a proteção aos direitos fundamentais dos cidadãos frente a atividade administrativa.

\subsection{Recorribilidade das decisões administrativas}

A proteção garantida pelo devido processo legal administrativo não deve se encerrar apenas no exame da questão que motivou o exercício da função administrativa, especialmente nos casos em que essa decisão foi resultado de um processo inadequado, indevido e irregular.

A recorribilidade das decisões está fundamentada em dois elementos que podem se apresentar individualmente ou conjuntamente. O primeiro elemento que justifica a possibilidade de impugnação de um ato decisório é a característica humana de não se conformar com decisões desfavoráveis, sentimento que naturalmente conduz a busca de mecanismos que possam reverter ou minimizar essa insatisfação. Por sua vez, o segundo elemento diz respeito a possibilidade humana de falhar e a necessidade de afastar os vícios que as decisões possam apresentar em decorrência do erro da autoridade decisória. Assim, a recorribilidade deve ser entendida muito além de uma simples readequação do ato decisório por conta de eventuais vícios formais ou materiais, mas, principalmente, como uma medida de reequilíbrio e harmonização frente a irresignação da parte afetada por uma decisão que tenha sido considerada injusta ou insatisfatória. Portanto, levando-se em conta que a recorribilidade transcende as situações em que possam ter ocorrido uma

\footnotetext{
35 Tem-se que os agentes públicos não podem decidir arbitrariamente em determinada situação concreta, pois encontram-se vinculados a uma regra geral formulada de maneira abstrata, que não considera pontualmente nenhum interesse senão o próprio interesse público. Essa vinculação ao mandamento normativo concretiza uma proteção contra o poder estatal absoluto, pois afasta ilegalidades, pessoalidades no tratamento dos cidadãos, motivações inexistentes ou irregulares, irrazoabilidades, desproporcionalidades, ineficiências, falta de transparência e cerceamento de defesa (DUGUIT, 1923, p.96).
} 
ilegalidade, tanto os atos decisórios injustos quanto os justos são passíveis de sofrerem a interposição de um recurso ${ }^{36}$.

Há uma relação interdependente entre o devido processo legal e o recurso, pois “o recurso, como parte integrante do devido processo legal, é alçado a instrumento capaz de, pelo controle interno da atividade decisória, garantir que o processo se realize com respeito a todas as suas balizas" (SANTOS, M. F., 2012, pp. 112-113). Cabe aqui uma divagação. As regras estabelecem os meios pelos quais é possível se praticar um ato, sendo que a observância dessas regras é condição obrigatória para que se atinja a finalidade desejada. Enquanto que a conveniência do ato é a medida da conformidade do ato praticado com as regras técnicas que o determinam, a justiça do ato diz respeito à conformidade do ato praticado com as regras morais estabelecidas, sendo que a conformidade entre o ato praticado, sua conveniência e a justiça compõe a esfera de legalidade do ato. Assim, há comandos jurídicos de cumprimento obrigatório para que se possa garantir a efetividade da conveniência e da justiça do ato praticado, ou seja, sua legalidade, sendo que o conjunto desses comandos jurídicos é denominado de devido processo legal. Dessa forma, sempre que o ato praticado não estiver em conformidade com as regras técnicas e com as regras morais - ou com as regras técnicas ou com as regras morais - será considerado ato viciado. Pode-se, diante do vício do ato praticado, adotar um ou outro comportamento: a eliminação do ato praticado ou a adequação do ato praticado. A eliminação do ato praticado é denominada de retificação do ato, enquanto que a adequação do ato a sua legalidade é denominada de convalidação do ato praticado. Contudo, se se nega eficácia ao ato imune de vícios ou a retificação ou convalidação do ato não atender aos interesses envolvidos, abre-se a possibilidade de utilização de outro remédio processual: o recurso (CARNELUTTI, 1956, pp. 285-286).

A recorribilidade das decisões não deve ser atribuída exclusivamente a nenhuma matéria do Direito (i.e. cível, penal ou trabalhista), pois a possibilidade de interposição de recursos diante de decisão proferida é decorrência da observância do devido processo legal. Assim, também no processo administrativo deve ser assegurado às partes o direito

\footnotetext{
${ }^{36}$ Confirmando essa concepção, NERY JR. afirma que "[o] direito de recorrer é independente dos eventuais vícios da sentença, que pode até não conter vício de nenhuma ordem, pois o seu pressuposto é a existência de uma decisão desfavorável, total ou parcialmente, a uma das partes ou que possa prejudicar a um terceiro. Isto porque o sistema processual, ao admitir o direito de a parte ou o interessado recorrer, considerou insuficiente o julgamento da causa em um único grau de jurisdição. De consequência, não somente a sentença injusta como também a justa estão sujeitas a recurso" (2004, p.220)
} 
à recorribilidade ${ }^{37}$ das decisões emitidas pelos agentes públicos, pois “o direito à ampla defesa não se restringe ao processo judicial, sendo a Constituição Federal, quanto a esse aspecto, expressa, quando se refere no mencionado art. $5^{\circ}$, LV, 'aos litigantes, em processo judicial ou administrativo"” (JORGE, 2007, p.30) $)^{38}$.

$\mathrm{Na}$ legislação brasileira, os recursos administrativos encontram fundamento em três elementos distintos: (i) o direito de petição; (ii) o contraditório e a ampla defesa (com os meios e recursos a ela inerentes); e (iii) o poder hierárquico.

$\mathrm{O}$ art. $5^{\circ}, \mathrm{XXXIV}, a$ da $\mathrm{CF} / 88$ assegura universal e gratuitamente o direito de se peticionar por meio escrito aos entes públicos em defesa de direitos individuais e coletivos, contra ilegalidades ou abuso de poder, devendo haver obrigatoriamente apreciação do conteúdo apresentado pelo ente competente em razão da matéria ${ }^{39}$. O direito de petição, garantia fundamental constitucionalmente eleita pelo ordenamento jurídico brasileiro, assegura aos cidadãos a possibilidade de postular à Administração Pública o reexame do ato decisório proferido em processo administrativo, pois os recursos administrativos materializam um pedido de reanálise do ato administrativo.

Por sua vez, o art. 5, $\mathrm{LV}$ da $\mathrm{CF} / 88$ se utiliza da expressão "com os meios e recursos a ela inerentes" para qualificar a extensão da ampla defesa assegurada aos cidadãos em processo administrativo. Nesse sentido, o texto constitucional é bastante claro e preciso ao assegurar, como direito fundamental, a utilização de todos os remédios juridicamente permitidos necessários para o exercício da defesa dos interesses e direitos individuais e coletivos envolvidos. Assim, se necessário o reexame para efetivar a defesa, será dispensada ao cidadão a possibilidade de interposição de recurso administrativo, ou seja, "[d]iante dessa garantia constitucional, o norte que deve orientar a interpretação das normas legais e regulamentares é o princípio da recorribilidade ou revisibilidade das decisões administrativas" (FERRAZ; DALLARI, 2012, p.285).

O poder hierárquico estabelece uma relação de coordenação e subordinação entre os órgãos integrantes da Administração Pública (PIETRO, 2011, p. 96), ordenando as

\footnotetext{
${ }^{37}$ CAIELLA explica que "o direito de recorrer é uma emanação conjunta do direito de peticionar ante as autoridades e da garantia de defesa. $\mathrm{O}$ recurso constitui um meio ou garantia de defesa do administrado como integrante do direito de ser ouvido, (...) dentro do denominado devido processo adjetivo" (2006, pp.261-262)

${ }^{38}$ Obviamente não se defende que as partes sempre possam recorrer contra toda e qualquer decisão prolatada, com ampla possibilidade de reexame da matéria analisada, pois, na verdade, a disposição constitucional relativa aos recursos refere-se somente ao devido processo legal, não sendo permitidos nenhuma espécie de abuso (JORGE, 2007, p.31).

${ }^{39}$ Conforme José Afonso da SILVA, o "direito de petição não pode ser destituído de eficácia. Não pode a autoridade a quem é dirigido escusar pronunciar-se sobre a petição, quer para acolhê-la quer para desacolhêla com a devida motivação" (2006, pp. 443-444)
} 
atividades administrativas por meio da repartição e escalonamento de funções entre os agentes distribuídos nos órgãos públicos, harmonizando o exercício da função administrativa nos diversos órgãos que compõe o ente público, controlando e fiscalizando a atividade administrativa com o objetivo de verificar a legalidade de seus atos e o cumprimento de suas obrigações.

O recurso administrativo, como instrumento de revisão ou reforma dos atos administrativos, se insere justamente nessa função de controle ${ }^{40} \mathrm{em}$ decorrência do poder hierárquico, pois dispõe ao cidadão os meios necessários para a verificação da legalidade do ato administrativo decisório e sua eventual correção em caso de violação dos princípios e normas.

\subsection{A questão do duplo grau de jurisdição na esfera administrativa ${ }^{41}$}

A premissa mais importante que se deve estabelecer de antemão quando se examina o duplo grau de jurisdição, é a de que recurso e duplo grau não se confundem, embora haja alguma correlação entre esses institutos ${ }^{42}$. Enquanto que o duplo grau de jurisdição se refere à possibilidade de conhecimento e reapreciação de todos os aspectos de uma mesma causa por autoridade julgadora diferente da que pronunciou a decisão, de modo que a decisão posteriormente proferida prevaleça sobre a decisão anterior, confirmando-a ou reformando-a (SANTOS, M. F., 2012, p.123), o recurso pode ser compreendido como o ato voluntário pelo qual a parte inconformada com a decisão proferida requer a reapreciação da causa pela mesma autoridade julgadora ou autoridade julgadora diversa ${ }^{43}$.

A concepção moderna do duplo grau de jurisdição originou-se em meio ao estabelecimento da nova ordem social na transição do Ancien Régime durante a

\footnotetext{
40 "O controle compreende duas funções distintas e complementares: (i) fiscalização dos atos e atividades de um poder; e (ii) correção dos atos ilegais, inconvenientes ou inoportunos exercidos por um poder" (PACCE, 2014, p. 380)

${ }^{41}$ A questão do duplo grau de jurisdição na esfera administrativa não se confunde com o tema do duplo grau obrigatório de jurisdição, comumente denominado de reexame necessário ou remessa oficial, cuja base normativa se encontra no art. $475 \mathrm{CPC}$ e se refere a obrigatoriedade da reapreciação de decisões que julguem improcedente a execução de dívida ativa da Fazenda Pública.

42، Tradicional é a correlação que se estabelece entre o instituto do recurso e o princípio do duplo grau de jurisdição, segundo o qual as lides ajuizadas devem submeter-se a exames sucessivos, como garantia de boa solução" (MOREIRA, J. C. B., 1993, p.211).

${ }^{43} \mathrm{O}$ conceito de recurso apresentado constitui-se como uma definição meramente genérica para que o instituto seja mais detidamente examinado em momento oportuno.
} 
Revolução Francesa ${ }^{44}$. A recorribilidade da generalidade das decisões e a multiplicidade de graus de jurisdição ocasionaram uma profunda instabilidade no sistema processual francês, caracterizada pela comercialização da justiça e pelo esvaziamento do poder decisório dos juízos de primeira instância ${ }^{45}$, motivo pelo qual, a Assembleia Nacional Constituinte (5 de maio de 1789), ao entender que a recorribilidade da generalidade das decisões e a multiplicidade de graus de jurisdição se tratavam de manifestações do absolutismo característico do Ancien Régime, propôs a supressão total dos recursos. Contudo, após sucessivos debates a respeito da recorribilidade e da pluralidade de instâncias $^{46}$, a Constitution de l'an III (22 de agosto de 1795) reestabeleceu definitivamente, por meio dos art. 211, 218 e 219, o duplo grau de jurisdição no sistema processual francês, medida adotada por diversas outros países (NERY Jr., 2004, p. 38).

Similarmente ao que ocorre com a recorribilidade das decisões, o duplo grau de jurisdição é fundamentado pela (i) falibilidade da autoridade julgadora, pela (ii) irresignação da parte vencida e pela (iii) necessidade de controle da decisão proferida (MARRARA; NOHARA, 2009, p.159), ou seja, o duplo grau de jurisdição é essencial para se afastar a possibilidade da autoridade julgadora única adotar uma postura despótica em razão da falta de controle sobre seu processo decisório (MONTESQUIEU, s/d, p.78). Assim, o duplo grau de jurisdição adota uma perspectiva de "garantia fundamental de boa justiça” (NERY JÚNIOR., 2004, p. 39), evitando abusos de poder, autoritarismos e arbitrariedades que poderiam decorrer da imutabilidade da decisão na ausência de mais de uma instância decisória (SANTOS, M. F., 2012, p.110).

É necessário, contudo, levar em consideração que o duplo grau de jurisdição apresenta uma certa instabilidade quanto a sua definição, sendo possível a identificação

\footnotetext{
${ }^{44}$ Cf. MIRANDA, "[e]nquanto a justiça era diretamente administrada pelo povo, ou pelo rei, a regra era a instância única. Nos primórdios, desconhecia-se a pluralidade das instâncias. Mas, depois, quando se tirou do povo, ou do rei, a função judiciária, introduziu-se a tendência a submeter-se a reexame, devido à possibilidade de erro ou de má-fé, a sentença judicial. Compreende-se que, primeiro, se desse tal função ao próprio rei, ou ao povo. A aparição da pluralidade de instâncias foi seguida por lenta e pertinaz investigação da melhor técnica para a composição dos tribunais e, consequiência, da admissão dos recursos e do processo dos recursos. Na Revolução Francesa, o princípio do duplo grau de jurisdição apareceu como firmado" (1974, p.19)

${ }^{45}$ Nesse sentido, SANTOS, M. A. explica que “[c]riaram-se juízes proprietários dos cargos, e esses, praticamente, se transformaram em proprietários da função judiciária. À irrecorribilidade das sentenças se substituiu a recorribilidade da generalidade das decisões, até de simples despachos, multiplicando-se os graus de jurisdição e, em conseqüência, os recursos. O sistema propiciava aos juízes o crescimento de suas rendas. Desmereceu-se a justiça, tornada objeto de comércio durante largos séculos” (2001, p.81)

${ }^{46}$ O Decreto de 01 de maio de 1790 estabeleceu o duplo grau de jurisdição ao assegurar a possibilidade de recursos contra as decisões dos juízos de primeiro grau. Por sua vez, o Ato Constitucional de 24 de junho de 1793 determinou que não caberia recurso contra as decisões da justiça civil, caracterizando-as como definitivas. (NERY Jr., 2004, p. 38)
} 
de duas correntes conceituais distintas. Há os autores que entendem pela desnecessidade da existência de hierarquia entre as autoridades julgadoras, isto é, o duplo grau de jurisdição corresponde à possibilidade do mérito da causa ser apreciado duas vezes por autoridades julgadoras distintas, não sendo necessário que a reapreciação seja realizada por autoridade julgadora de categoria hierárquica superior à daquela que efetuou o primeiro juízo ${ }^{47}$. Existe ainda autores que afirmam que o duplo grau de jurisdição somente se efetivará se a reapreciação do mérito da questão for obrigatoriamente desenvolvida por uma autoridade julgadora hierarquicamente superior ${ }^{48}$.

Parece-nos mais interessante o entendimento de que ao duplo grau de jurisdição - ainda mais levando-se em conta a perspectiva do processo administrativo - importa mais a questão da prevalência da decisão posterior sobre a decisão anterior do que a controvérsia sobre a superposição ou hierarquização das autoridades julgadoras (GUEDES, 2002, p. 287).

Em razão da inexistência de previsão expressa da obrigatoriedade do duplo grau de jurisdição na $\mathrm{CF} / 88$, no direito brasileiro há a questão específica da definição do duplo grau como postulado constitucional ou norma de previsão ordinária ${ }^{49}$. Para alguns autores, embora a $\mathrm{CF} / 88$ mencione a existência de tribunais e dos recursos, não determina a obrigatoriedade do duplo grau de jurisdição, demonstrada pela presença de ações de competência originária dos tribunais (MORAES, 2011, pp.90-91) ${ }^{50}$, sendo facultada à legislação ordinária, portanto, sua regulamentação ${ }^{51}$. Outros autores consideram que

\footnotetext{
${ }^{47}$ Conforme LIEBMAN, "o duplo grau exige que o mérito da causa possa ser apreciado e julgado - no seu conjunto - duas vezes por juízes diversos, não porém, que todas as questões discutidas, e cada uma delas, sejam decidias duas vezes sucessivamente" (2001, p.152). Por sua vez, para NERY Jr., o duplo grau de jurisdição "[c]onsiste em estabelecer a possibilidade de a sentença definitiva ser reapreciada por órgão de jurisdição, normalmente de hierarquia superior à daquele que a proferiu, o que se faz de ordinário pela interposição de recurso. Não é necessário que o segundo julgamento seja conferido a órgão diverso ou de categoria hierárquica superior à daquele que realizou o primeiro exame' (2004, p.44)

${ }^{48}$ Segundo JORGE, "o simples reexame da causa não permite concluir pela existência do duplo grau de jurisdição, sendo imprescindível que a segunda análise seja feita por um órgão de hierarquia superior" (2007, p.171). Por sua vez, MOREIRA, J. C. B., entende que o duplo grau de jurisdição "decorre a necessidade de permitir-se nova apreciação da causa, por órgão situado em nível superior na hierarquia judiciária, mediante a interposição de recurso ou expediente análogo [...] após a primeira decisão" (1993, pp. 238-239)

${ }^{49}$ Cabe salientar que a única Constituição brasileira que garantiu expressamente o duplo grau de jurisdição foi a Constituição Imperial de 25 de março de 1824, que em seu art. 158 determinou que "[p]ara julgar as Causas em segunda, e ultima instancia haverá nas Provincias do Imperio as Relações, que forem necessarias para commodidade dos Povos" (JORGE, 2007, p. 171)

${ }^{50}$ Nesse sentido, "é correto afirmar que o legislador infraconstitucional não está obrigado a estabelecer, para toda e qualquer causa, uma dupla revisão em relação ao mérito, principalmente porque a própria Constituição Federal, em seu art. $5^{\circ}$, LXXVIII, garante a todos o direito à tutela jurisdicional tempestiva" (MARINONI; ARENHART, 2011, p.498)

${ }^{51}$ Certamente é LASPRO o mais citado como defensor desse argumento, pois afirma que "a Constituição tacitamente admitiu que a supressão do direito de apelar não ofende o direito ao devido processo legal, na
} 
embora não haja uma previsão explícita do duplo grau de jurisdição no texto da $\mathrm{CF} / 88$, sua existência estaria relacionada à conjugação de diversos princípios constitucionais, especialmente o devido processo legal, determinado pelo art. $5^{\circ}$, inciso $\mathrm{LV}$ da $\mathrm{CF} / 88$ (JORGE, 2007, p. 172) ${ }^{52}$.

Para os fins desse estudo, considera-se que o duplo grau de jurisdição é uma garantia constitucional decorrente do devido processo legal, implicitamente prevista nos incisos LIV e LV do art. $5^{\circ}$. Assim, a CF/88 se encarregou de harmonizá-la com os demais princípios constitucionais, estabelecendo-a como uma garantia instrumental para a efetivação da ampla defesa e do contraditório e uma baliza para o sopesamento entre a segurança jurídica e a eficiência processual (NERY JÚNIOR, 2004, p.40).

Não somente no âmbito jurisdicional, mas também na esfera administrativa, o duplo grau de jurisdição na esfera administrativa é uma questão que costuma motivar debates entre a doutrina e a jurisprudência brasileira.

Em geral, a doutrina brasileira de direito administrativo ${ }^{53}$ acredita que, embora não haja expressamente a previsão constitucional do duplo grau de jurisdição na esfera administrativa - assim como ocorre com o duplo grau de jurisdição no processo jurisdicional -, a pluralidade de instâncias para o processo administrativo está implicitamente garantida pelos incisos LIV e LV da CF/88, como uma das manifestações do devido processo legal administrativo. Reforçando essa noção, e de certa forma regulando a realização do duplo grau de jurisdição na esfera administrativa, os art. 17 e 57 da Lei Federal n. 9.784/99 estabelecem a necessidade do processo administrativo ser iniciado perante a autoridade de menor grau hierárquico e a tramitação processual por no máximo três instâncias administrativas, respectivamente. Essa concepção é adequadamente resumida por ROCHA, que afirma que:

Também vinculado ao direito à ampla defesa é o direito à revisão e/ou recurso administrativo. Este é uma extensão do direito à ampla defesa, uma forma de exercêlo. É a Constituição da República que, no mesmo art. $5^{\circ}$, inciso LV, acopla ao direito

medida em que garantido está o acesso à mais alta Corte, a fim de proteger os direitos fundamentais" (1995, p.159)

52 A esse respeito, GUEDES afirma ser "possível que se faça a conexão do duplo grau de jurisdição com diversos princípios constitucionais do processo, entre os quais se destaca o devido processo legal e a ampla defesa, a isonomia, o dever de fundamentar as decisões, a publicidade, a inafastabilidade do controle judicial, o juiz natural e mesmo a oralidade" (2002, p.295).

${ }^{53}$ Cf. DI PIETRO, Maria Sylvia Zanella. Direito administrativo. 24. ed., São Paulo: Atlas, 2011, pp. 634635; MARRARA, Thiago; NOHARA, Irene Patrícia. Processo administrativo: Lei n. 9.784/99 comentada. São Paulo: Atlas, 2009, p.159; FERRAZ, Sergio; DALLARI. Processo administrativo. 3. ed. rev. amp., São Paulo: Malheiros, 2012, p. 134; D’EÇA, Fernando Luiz da Gama Lobo. O processo tributário na Constituição e a especial atenção ao processo administrativo in AMARAL, Antônio Carlos Rodrigues do (coord). Curso de Direito Tributário. 2002, pp. 229-267. 
à ampla defesa "os meios e os recursos a ela inerentes". O interessado reapresenta a sua argumentação e o seu arrazoado na instância recursal e vê a sua fundamentação ser objeto de novo exame. Na verdade, o recurso é um segundo momento de defesa, agora na instância e perante o juízo recursal competente. As decisões administrativas, inclusive e principalmente aquelas proferidas no processo, podem conter equívocos. São obras humanas e, como tal, sujeitas a desvios e a falhas, como os próprios homens. Daí a necessidade que se foi demonstrando de que as condutas estatais especialmente aquelas havidas numa relação de contraditório e de questionamento e talvez comprometimento de direitos - submetem-se a duplo exame, porque a oportunidade de haver uma segunda análise propicia uma melhor conclusão e uma maior segurança, diretamente, para o interessado e, reflexivamente, para a coletividade. À própria autoridade que tenha proferido a decisão recorrida é oferecida uma oportunidade de reexame, em geral, vez que a ela é que se dirige o recurso e o pedido de reconsideração, o que, não ocorrendo, determina a remessa do mesmo à autoridade hierarquicamente superior. Os recursos administrativos são específicos ou não, conforme sejam contemplados na legislação infraconstitucional para processos determinados (casos do processo de licitação ou do processo disciplinar, por exemplo) ou para o processo administrativo em geral. (1997, p.22)

Nos tribunais superiores, a questão do duplo grau de jurisdição na esfera administrativa é incidentalmente abordada nos casos que analisavam se os dispositivos normativos que previam a obrigatoriedade de depósito prévio para prosseguimento de recursos administrativos haviam sido recepcionados pela $\mathrm{CF} / 88$ ou violavam os princípios do devido processo legal, da ampla defesa e do contraditório (art. 5, incisos LIV e LV) ${ }^{54}$.

No Supremo Tribunal Federal, a Medida Cautelar na Ação Direta de Inconstitucionalidade ADI n.1.049 MC/DF, julgada em 18 de maio de 1995, foi proposta para examinar a constitucionalidade do - entre outros dispositivos normativos - art. 93 da Lei n. 8.212/91 (com redação dada pela Lei n. 8.870/94), que estabelecia que o recurso administrativo contra decisão do INSS que aplicasse multa por infração a dispositivo da legislação previdenciária somente teria seguimento se instruído com a prova do depósito da multa monetariamente atualizada. Dentre os votos proferidos, chama a atenção o do ministro Sepúlveda Pertence, que, ao considerar que "como o devido processo legal não impõe sequer o direito à existência do recurso administrativo, não vejo de que maneira o condicionamento de seu exercício ao depósito poderia afetar a garantia do devido processo legal" (p.221), colateralmente negou a existência constitucional do duplo grau de jurisdição na esfera administrativa. $\mathrm{O}$ indeferimento do pedido de medida liminar de suspensão do art. 93 da Lei n. 8.212/91 por maioria dos votos, firmou o entendimento da constitucionalidade da exigência do depósito prévio para o Supremo Tribunal Federal,

\footnotetext{
${ }^{54} \mathrm{O}$ tema da obrigatoriedade de depósito prévio para recursos administrativos será abordado em item específico.
} 
justificando-se a ausência de obrigatoriedade do duplo grau de jurisdição na esfera administrativa.

O Recurso Extraordinário RE n. 210.246/GO, julgado em 12 de novembro de 1997, examinava exclusivamente o descabimento da exigência de depósito prévio do valor correspondente a multa aplicada pelo Ministério do Trabalho como condição para o conhecimento de recurso administrativo, como estabelecido pelo art. $636 \S 1^{\circ}$ da CLT. Nessa ocasião, o ministro Octavio Gallotti entendeu "que não há direito constitucional ao duplo grau de jurisdição, seja na via administrativa, seja na via judicial” (p.641). Dessa forma, por votação majoritária, foi mantido o entendimento adotado pela ADI n.1.049 $\mathrm{MC} / \mathrm{DF}$.

A Ação Direta de Inconstitucionalidade ADI n.1.976/DF teve importância paradigmática para a definição da questão do duplo grau de jurisdição no Supremo Tribunal Federal $^{55}$. Enquanto que na medida liminar da ADI n.1.976/DF, julgada em 06 de outubro de 1999, o ministro relator Moreira Alves sustentou que "[s]e não há nenhum princípio segundo o qual haja constitucionalmente a necessidade de duplo grau de jurisdição, com maior razão não há constitucionalmente duplo grau em processo administrativo" (p.101) - tendo o acórdão entendido pela constitucionalidade do depósito prévio de $30 \%$ da exigência fiscal definida na decisão do processo administrativo de determinação e exigência de créditos tributários da União -, no julgamento final, ocorrido em 28 de março de 2007, o ministro relator Joaquim Barbosa considerou que "[a] consagração do direito ao recurso administrativo como um componente essencial do direito de petição torna acessório o debate acerca de um direito ao duplo grau de jurisdição", motivo pelo qual, o ministro acrescenta que "[a] imposição do depósito prévio já pressupõe uma suposta 'segunda instância administrativa', [não se discutindo], portanto, a existência dessa 'segunda instância', mas o acesso a ela" (p.100). Firmou-se não somente o entendimento pela inconstitucionalidade do depósito prévio, mas igualmente assentou jurisprudencialmente para o tribunal a concepção da existência do duplo grau de jurisdição na esfera administrativa.

A perspectiva adotada pelo Superior Tribunal de Justiça, contrariamente ao que ocorre no Supremo Tribunal Federal, é bastante conservadora e merece uma forte ressalva. O entendimento do tribunal é uniforme e praticamente não sofreu alteração,

\footnotetext{
55 Tamanha foi a importância atribuída ao julgamento da ADI n.1.976/DF, que esse se tornou um dos pressupostos jurisprudências para a elaboração da Súmula Vinculante n.21, que será melhor examinada quando se analisar o depósito prévio e os recursos administrativos.
} 
tendo consolidado a noção de que a $\mathrm{CF} / 88$ não haveria determinado o duplo grau de jurisdição como uma garantia na esfera administrativa.

Dentre as decisões, destacam-se o Mandado de Segurança MS n. 10.269/DF e o Recurso em Mandado de Segurança RMS n.22.064/MS, pois constituíram-se como fortes precedentes, sendo amplamente citados como fundamentação dos argumentos dos ministros. No MS n. 10.269/DF, julgado em 14 de setembro de 2005, o ministro relator José Delgado teve seu voto vencido, dando lugar ao relatório do ministro relator para acórdão Teori Albino Zavascki que sustentou que o Superior Tribunal Federal "na esteira da orientação firmada pelo Supremo tribunal Federal, apreciando o tema da legitimidade do depósito prévio exigido para a interposição de recurso administrativo, assentou o entendimento segundo o qual não há, na Constituição de 1988, garantia de jurisdição administrativa". No RMS n.22.064/MS, julgado em 20 de setembro de 2011, o ministro relator Vasco Della Giustina destacou que o Superior Tribunal de Justiça "tem entendimento assente de que a Constituição Federal não contemplou a garantia do duplo grau de jurisdição na esfera administrativa”.

Enquanto que a decisão proferida para o MS n.10.269/DF segue a tendência ${ }^{56}$ adotada pelo Supremo Tribunal Federal à época do julgamento, o Superior Tribunal de Justiça, ao adotar o MS n. 10.269/DF como base decisória do RMS n.22064 para sustentar a posição contrária ao duplo grau de jurisdição na esfera administrativa, contraria a tendência contemporânea do Supremo Tribunal Federal que, a partir da ADI n.1.976/DF, adotou o entendimento de que a $\mathrm{CF} / 88$ de fato garantiu o duplo grau de jurisdição na esfera administrativa como uma manifestação do devido processo legal administrativo por meio dos incisos LIV e LV do art. $5^{\circ}$.

Ainda que a Súmula Vinculante 21 do Supremo Tribunal Federal e a Súmula 373 do Superior Tribunal de Justiça ${ }^{57}$ tenham consolidado a inconstitucionalidade ou ilegitimidade da exigência de depósito ou arrolamento prévio para admissibilidade de recurso administrativo, a ausência de um alinhamento jurisprudencial entre os dois tribunais quanto a questão do duplo grau de jurisdição na esfera administrativa é responsável pela manutenção da judicialização de diversos casos envolvendo direta ou indiretamente a possibilidade de apresentação de recurso administrativo.

\footnotetext{
${ }^{56} \mathrm{O}$ ministro relator fundamento o MS n. 10.269/DF com as seguintes decisões do Supremo Tribunal Federal: ADIMC n.1.049, a ADI n. 836-6/DF, a ADI n. 922/DF, a ADI n.1.976/DF, o RREE n. 210244/GO e o RREE n. 235833/GO.

${ }^{57}$ Essas súmulas serão analisadas em item específico acerca do depósito prévio.
} 


\subsection{Considerações acerca dos pressupostos dos recursos administrativos}

A opção da CF/88 pela unicidade de jurisdição (art. 50, XXXV) estabeleceu o exercício da função jurisdicional como de competência típica do Poder Judiciário. Assim, o contencioso administrativo foi substituído pela tutela jurisdicional do Estado, delegando ao judiciário a preponderância para dirimir, pacificar e resolver em caráter definitivo questões envolvendo cidadãos e a Administração Pública, por meio do chamado controle judicial dos atos administrativos ${ }^{58} 59$.

O sistema de unicidade de jurisdição, contudo, não pressupõe a inexistência da processualidade administrativa ou a impossibilidade da realização do controle administrativo $^{60}$, pois, enquanto o controle administrativo decorre do poder de autotutela da Administração Pública (DI PIETRO, 2012, p.794) ${ }^{61}$, o processo é o instrumento por meio do qual se desenvolve a função administrativa ${ }^{62}$, e pode concretizar tanto a "formulação de uma política administrativa, ou a produção de um ato administrativo qualquer, quanto a dirimência de um litígio" (FERRAZ; DALLARI, 2012, p.28) ${ }^{63}$.

\footnotetext{
${ }^{58}$ MEDAUAR (2012, p.186) explica que o controle jurisdicional da Administração Pública incide sobre os atos, processos e contratos administrativos, operações materiais e omissão ou inércia do ente público, devendo necessariamente ser iniciado mediante provocação e caracteriza-se por ser corretivo ou repressivo. ${ }^{59}$ PAULSEN; ÁVILA; SLIWKA (2007, p.413) afirmam que, em decorrência do princípio da jurisdição una, " o ato administrativo pode ser controlado pelo Judiciário e que apenas a decisão deste é que se torna definitiva, com o trânsito em julgado, prevalecendo sobre eventual decisão administrativa que tenha sido tomada ou pudesse vir a ser tomada. Considerando que o contribuinte tem direito a se defender na esfera administrativa, não faz sentido a sobreposição dos processos administrativo e judicial. A opção pela discussão judicial, antes do exaurimento da espera administrativa, demonstra que o contribuinte desta abdicou, levando o seu caso diretamente ao Poder ao qual cabe dar a última palavra quanto à interpretação e à aplicação do Direito, o Judiciário. Entretanto, tal pressupõe a identidade de objeto nas discussões administrativa e judicial. Caso a ação anulatória fira, e.g., a questão da constitucionalidade da norma tributária impositiva e o recurso administrativo se restrinja a discussões quanto à apuração do valor devido, em razão de questões de fato, não haverá a identidade que tornaria sem sentido a concomitância das duas esferas".

${ }^{60}$ Em razão da autotutela, a Administração Pública exerce controle "sobre os próprios atos, com a possibilidade de anular os ilegais e revogar os inconvenientes ou inoportunos, independentemente de recurso ao Poder Judiciário" (DI PIETRO, 2012, p.70)

${ }^{61}$ Nesse mesmo sentido, STF Súmula no 346 - 13/12/1963 - Súmula da Jurisprudência Predominante do Supremo Tribunal Federal - Anexo ao Regimento Interno. Edição: Imprensa Nacional, 1964, p. 151. Administração Pública - Declaração da Nulidade dos Seus Próprios Atos: “A administração pública pode declarar a nulidade dos seus próprios atos" e STF Súmula no 473 - 03/12/1969 - DJ de 10/12/1969, p. 5929; DJ de 11/12/1969, p. 5945; DJ de 12/12/1969, p. 5993. Republicação: DJ de 11/6/1970, p. 2381; DJ de 12/6/1970, p. 2405; DJ de 15/6/1970, p. 2437. Administração Pública - Anulação ou Revogação dos Seus Próprios Atos: “A administração pode anular seus próprios atos, quando eivados de vícios que os tornam ilegais, porque deles não se originam direitos; ou revogá-los, por motivo de conveniência ou oportunidade, respeitados os direitos adquiridos, e ressalvada, em todos os casos, a apreciação judicial".

${ }^{62}$ Função tipicamente exercida pela Administração Pública, "é aquela exercida pelo Estado ou por seus delegados, subjacentemente à ordem constitucional e legal, sob regime de direito público, com vistas à alcançar os fins colimados pela ordem jurídica" (CARVALHO FILHO, 2012, p.4)

${ }^{63}$ Nesse sentido DI PIETRO explica que processo "existe sempre como instrumento indispensável para o exercício de função administrativa; tudo o que a Administração Pública faz, operações matérias ou atos jurídicos, fica documentado em um processo; cada vez que ela for tomar uma decisão, executar uma obra,
} 
Não há identidade entre a processualidade na esfera jurisdicional e na via administrativa, isso porque, o processo administrativo, enquanto instrumento da função administrativa, não tem como finalidade exclusiva a execução da lei, não possui caráter substitutivo em relação às partes e não possui a capacidade de fazer das suas decisões coisa julgada (MEDAUAR, 1993, p.54) ${ }^{64}$. Esses sinais distintivos conduzem "[t]anto processualistas como administrativistas [a] cogitar de uma processualidade que transcende à função jurisdicional e, portanto, de uma processualidade administrativa" (MEDAUAR,1993, p.16). Assim, a compreensão do processo administrativo como a "domesticação da atuação administrativa" (BACELLAR FILHO, 2003, p.133) é suficiente para afastar definitivamente dúvidas a respeito da existência de uma processualidade exteriormente à função jurisdicional.

Além disso, o processo administrativo caracteriza-se como instrumento indispensável à garantia dos direitos individuais (MOREIRA, E. B., 2007, p.66), pois institucionaliza a participação popular na defesa dos interesses particulares e coletivos ao assegurar o devido processo legal, a ampla defesa e o contraditório na formação do ato administrativo decisório, ou seja, viabiliza a consensualidade administrativa.

Há que se evidenciar, contudo, a importante relação entre o exercício da função administrativa e o seu respectivo controle, isto é, entre o processo administrativo e o controle administrativo. Enquanto que o processo administrativo confere legitimidade ${ }^{65}$ ao ato administrativo decisório (LUHMANN, 1980, p.30), a possibilidade de controle do ato decisório confere eficácia ${ }^{66}$ ao processo administrativo.

O controle do ato decisório em sede processual na via administrativa é desencadeado pelo recurso administrativo, que representa tanto o mecanismo de prolongamento da defesa dos interesses individuais quanto uma das maneiras de se

celebrar um contrato, editar um regulamento, o ato final é sempre precedido de uma série de atos materiais ou jurídicos, consistentes em estudos, pareceres, informações, laudos, audiências, enfim, tudo o que for necessário para instruir, preparar e fundamentar o ato final objetivado pela Administração" (2012, p.678)

${ }^{64}$ Conforme GARCIA DE ENTERIA e RAMON FERNADEZ (1982, p.383), não há monopólio judicial do processo, inexistindo interdependência estrutural ou interna entre essas espécies de processo, de modo que não há a necessidade de se excessivamente jurisdicionalizar o processo administrativo, enquanto esse servir a finalidades específicas da Administração Pública, ou seja, há semelhanças e diferenças entre as duas espécies de processualidade, em decorrência das naturezas distintas de suas finalidades.

${ }^{65}$ Segundo LUHMANN, legitimidade é a "disposição generalizada para aceitar decisões de conteúdo ainda não definido, dentro de certos limites de tolerância" (1980, p.30)

${ }^{66}$ Não será desenvolvida uma teoria da eficácia, nem serão debatidas as diversas teorias filosóficas sobre o conceito de eficácia. Nesse sentido, deve-se entender, para os fins dessa análise, eficácia como "o grau [com] que uma determinada regra provoca mudança comportamental [n]o destinatário, atingindo seus objetivos políticos ou resolvendo uma situação de ilicitude" (NOGUEIRA, 2013, p.93) 
assegurar a regularidade e promover a correção da atividade administrativa (MEDAUAR, 2012, p.55).

A interposição de recurso não dá início a um novo processo administrativo, ou seja, o recurso administrativo não instaura nova relação processual, prolongando aquela anteriormente existente para que se proceda ao reexame da questão. Assim, a finalidade fundamental do recurso administrativo é possibilitar a impugnação do ato administrativo decisório (JORGE, 2007, p.22).

Especificamente quanto ao reexame da questão, não há obrigatoriedade de que o recurso administrativo seja encaminhado à autoridade administrativa hierarquicamente superior àquela que expediu a decisão, sendo permitido a reapresentação da questão à autoridade julgadora para reconsideração.

Ao passo que o elemento essencial do recurso administrativo é a reapreciação da matéria apresentada, o duplo grau de jurisdição exige que não haja identidade entre as autoridades julgadoras, independentemente de existir hierarquia entre elas. Assim,

\footnotetext{
[n]ão faz parte da essência do conceito de recurso que o seu julgamento seja realizado por um órgão de hierarquia superior e distinta daquele que proferiu a decisão recorrida. A característica fundamental dos recursos é propiciar o reexame da matéria anteriormente decidida [pela Administração Pública], mesmo que seja feito pelo próprio prolator da decisão recorrida. Não se pode pretender associar aos recursos a noção direta e indissociável do duplo grau de jurisdição. As características fundamentais dos recursos são a voluntariedade e a obtenção de novo julgamento por parte [da Administração Pública] (devolução), sem que esteja relacionado a graus de jurisdição distintos. (JORGE, 2007, p.24)
}

Portanto, é possível concluir que o duplo grau de jurisdição não é pressuposto lógico da possibilidade de interposição de recurso administrativo, ou seja, ainda que o duplo grau de jurisdição se relacione com a possibilidade de apresentação de recurso administrativo, não há razoabilidade no entendimento da dependência dos recursos ao duplo grau de jurisdição.

Nesse contexto se coloca a crítica ao entendimento adotado pelo ministro Octavio Gallotti no julgamento do RE n.210.246/GO:

entendo que não há direito constitucional ao duplo grau de jurisdição, seja a via administrativa, seja na via judicial e, por esse motivo, a lei, ao criar um recurso que poderia não instituir, pode submetê-lo à exigência de depósito, ficando a ampla defesa assegurada quanto à decisão de primeira instância. (p.641)

Há claramente, por parte do ministro Octavio Gallotti, a associação entre o duplo grau de jurisdição e a possibilidade de apresentação de recurso administrativo, sendo a 
existência do último dependente do reconhecimento constitucional do primeiro. O recurso administrativo, enquanto manifestação do devido processo legal, não se subordina ao reconhecimento constitucional do duplo grau de grau de jurisdição, de modo que, embora não haja pluralidade de instâncias, existirá a possibilidade de impugnação do ato administrativo decisório por meio da interposição de pedido de reconsideração. Igualmente, ao estabelecer o devido processo legal administrativo, o art. $5^{\circ}$, inciso LV da $\mathrm{CF} / 88$ impede que o legislador infraconstitucional restrinja a recorribilidade das decisões administrativas, ou seja, a criação de determinado recurso administrativo não se caracteriza como mera faculdade do legislador infraconstitucional, conforme afirmação do ministro Octavio Gallotti, especialmente diante da compreensão de que o recurso administrativo "retira o arbítrio de quem decide e obriga a que a decisão proferida seja devidamente fundamentada e motivada, abrindo ensejo à possibilidade de controle" (FERRAZ; DALLARI, 2012, p.139), constituindo-se como importante ferramenta do controle administrativo.

\subsection{A confiabilidade das soluções administrativas: peticionar ao Judiciário é mais eficaz do que os recursos administrativos?}

Ainda que a discussão teórica normalmente trate de controvérsias terminológicas e substanciais do recurso administrativo ${ }^{67}$, a experiência prática está muito mais vinculada à confiabilidade dos recursos administrativos como instrumentos suficientemente eficazes para a solução das questões apresentadas pelos cidadãos ao ente público. A atividade administrativa frequentemente está associada a condutas que tenham por finalidade o favorecimento de terceiros ou o benefício do próprio servidor público competente para o exercício da função administrativa naquela situação, assim "a indiscutível ineficiência da administração pública brasileira tem constituído argumento reforçador dos interesses privatistas" (SIQUEIRA, 1990, p.65) e "[s]em a confiança popular, as instituições continuam a funcionar desligadas da realidade social e, o que é mais importante, funcionam mal" (MOISÉS, 1989, p.75) ${ }^{68}$.

\footnotetext{
67 Conforme MEDAUAR, “[n]o Brasil, além da oscilação doutrinária entre processo e procedimento, registra-se a conexidade de processo administrativo a processo disciplinar, o que implica em visão reducionista da processualidade administrativa" (1998, p.30)

68 Segundo MOISÉS, “[a] democracia brasileira está relativamente consolidada - a maior parte dos especialistas reconhece isso. Mas ela enfrenta um paradoxo: as instituições democráticas são objeto de ampla e continuada desconfiança dos cidadãos brasileiros. Pesquisas recentes mostram que, apesar do apoio ao regime democrático per se, cerca de $2 / 3$ dos brasileiros não confiam - em diferentes graus - em parlamentos, partidos, executivos, tribunais de justiça e serviços públicos de saúde, educação e segurança.
} 
A desconfiança de que a autoridade administrativa competente para reapreciação da questão em sede recursal desempenhará sua atividade de maneira política, tendenciosa, partidária e corporativista com vistas a favorecer terceiros, mesmo que isso venha a violar direitos e garantias fundamentais e princípios constitucionais, enfraquece a via administrativa, reduzindo a eficácia dos recursos administrativos. Consequentemente, a opção por soluções judiciais tende a ser considerada mais conveniente, por ser supostamente menos corrompida do que a administrativa, não obstante, o judiciário também esteja enfrentando uma crise de legitimidade das instituições democráticas (MOISÉS, 2005) ${ }^{69}$.

A confiabilidade do recurso administrativo como meio prioritário para a solução da questão administrativa sensibiliza-se ainda mais diante da não-obrigatoriedade de esgotamento da via administrativa para pleitear-se a tutela jurisdicional ${ }^{70}$. Existe certa uniformidade no entendimento do Supremo Tribunal Federal acerca dessa questão:

AGRAVO REGIMENTAL EM AGRAVO EM RECURSO ESPECIAL. PREVIDÊNCIA PRIVADA. VIOLAÇÃO AO ART. 535 DO CPC. NÃO CONFIGURAÇÃO. PRESTAÇÃO DE CONTAS. LEGITIMIDADE DO PARTICIPANTE. ESGOTAMENTO DA VIA ADMINISTRATIVA. IMPOSSIBILIDADE. DESNECESSIDADE. FORMA DE PRESTAÇÃO DE CONTAS. DEVER DE PRESTAR CONTAS DE FORMA CLARA E INTELIGÍVEL. RECURSO NÃO PROVIDO. 1. Não há se falar em violação ao art. 535 do CPC, pois o Tribunal a quo dirimiu todas as questões necessárias ao deslinde do litígio, sendo dispensável que venha a examinar todos as alegações e fundamentos expendidos pelas partes. 2. O participante possui legítimo interesse em demandar a respectiva entidade de previdência privada em ação de prestação de contas para buscar o esclarecimento sobre as importâncias vertidas ao fundo. 3 . $\underline{\text { esgotamento da via }}$ administracão administrativa não é condicão para o surgimento do interesse em ajuizar ação de prestação de contas, especialmente quando as informacõos a que os participantes têm acesso se apresentam de maneira genérica. 4. A prestação de contas por entidade de previdência privada deve ser apresentada de maneira clara e inteligível. Caso não seja disponibilizada na forma mercantil, não é permitido ao magistrado desconsidera-las apenas por suposta violação ao artigo 917 do Código de Processo Civil, mas deve verificar, acima de tudo, se as contas apresentadas atingem as finalidades do processo e, caso positivo, afastar o rigor da norma. 5. Agravo regimental não provido. (SUPREMO TRIBUNAL FEDERAL. Agravo regimental no Agravo em Recurso Especial n. 150390 SP 2012/0039143-4, Relator: Ministro Luís Felipe Salomão, j. 09 abr. 2013) (grifo)

Surveys realizados entre 1989 e 1993 revelaram que a percepção negativa das instituições atravessa todos os segmentos de renda, escolaridade, idade e distribuição ecológica, chegando a influir sobre a disposição dos cidadãos para participar de processos políticos, como a escolha de governos (MOISÉS, 1995)" (2005, p.34).

${ }^{69}$ DALLARI afirma que "[a] desconfiança em relação ao processo administrativo sempre fez com que os interessados preferissem se valer, imediatamente, da via judicial” (2006, p.228)

${ }^{70}$ A inafastabilidade da tutela jurisdicional é decorrência da unicidade de jurisdição (art. $5^{\circ}$, inciso XXXV $\mathrm{CF} / 88)$. 
Nesse agravo regimental, o Supremo Tribunal Federal, reforçando a desnecessidade de esgotamento da via administrativa para ajuizamento de demandas no judiciário, determina que é possível a apresentação de ação de prestação de contas para buscar esclarecimentos quanto a determinada importância, mesmo que essa questão ainda não tenha terminado de ser analisada na via administrativa.

Não obstante, a opção pelo âmbito judicial não necessariamente representa significativa vantagem sobre o procedimento recursal administrativo. Dessa maneira, é interessante analisar as vantagens e desvantagens representadas pela escolha da tutela jurisdicional ou administrativa.

Conforme explicado anteriormente, como resultado dos princípios da oficialidade, da verdade material e da eficiência, os recursos administrativos permitem a apresentação de novas provas e a realização de novas alegações em sede recursal. Como afirma DI PIETRO, “[o] recurso administrativo vai deslocar a competência para a correção do ato, pois, no momento em que é interposto, a matéria sai da competência da autoridade que o emitiu e passa a ser da competência daquela que decidirá" (1996, p.160), renovando, assim, a necessidade da realização do interesse público primário, motivo pelo qual a autoridade em sede recursal deve envidar seus melhores esforços para buscar a verdade, mesmo que valendo-se de elementos que somente foram apresentados para exame no procedimento recursal. Nesse sentido:

\footnotetext{
O recurso administrativo configura um meio de proteção do administrado que assim pode impugnar um ato que o agrava e implica o desenvolvimento de meios de controle dentro da função administrativa do Estado, a medida em que lhe chama a atenção para a adoção de decisões de fundo mais apropriadas quanto ao mérito, oportunidade ou conveniência. Controlando suas próprias resoluções, ao processar e resolver recursos, a Administração protege o direito ou interesse do particular. Seria inconcebível a Administração em um Estado Democrático de Direito sem a existência de recursos administrativos, meios jurídicos que definitivamente contribuem para manter a legalidade dentro da Administração Pública (CAIELLA, 2006, p.262)
}

Em outras palavras, a escolha pelo esgotamento da via por meio da interposição de recurso administrativo permite que a atuação da Administração Pública se volte mais intensamente ao atendimento do interesse público, focada na realização dos princípios constitucionais e garantias fundamentais.

Além disso, muito embora o controle judicial dos atos administrativos "tenha se estendido significativamente ao longo do tempo, especialmente por foça de princípios como o da razoabilidade e da moralidade administrativa, o Judiciário, a princípio, não avalia o mérito da decisão administrativa" (MARRARA, NOHARA, 2009, p.361), 
devendo se limitar as questões de legalidade. Assim, somente a Administração Pública poderá analisar o mérito da decisão emitida, reformulando a avaliação quanto aquilo que entendeu ser conveniente e oportuno.

Finalmente, o recurso administrativo tem papel fundamental no auxílio ao desafogamento do judiciário ocasionado pelo volume de processos acumulados e do acréscimo de novas ações protocoladas ao longo de cada ano. Apenas a título de exemplo, o Justiça em números 2013, relatório do Superior Tribunal de Justiça, apontou que em 2012, 261.382 novos casos juntaram-se aos 316.317 casos pendentes de julgamento naquele tribunal (SUPERIOR TRIBUNAL DE JUSTIÇA, 2013, pp.30-31).

Não se pode mais conceber o judiciário como única instituição competente para solucionar os conflitos sociais. A crise da tutela jurisdicional comprova a necessidade de se encontrar novos métodos de solução de conflitos, por meio de mecanismos mais pacíficos, céleres, efetivos e menos onerosos no atendimento aos requisitos impostos pelo Estado. O recurso administrativo se insere nessa lógica, ao permitir que a própria Administração Pública reveja suas decisões, corrigindo-as quando necessário, de modo a evitar que a demanda atinja o Poder Judiciário (FORTINI; PEREIRA; CAMARÃO; 2012, p.87), agravando ainda mais a situação de precariedade.

\section{Considerações finais sobre os aspectos históricos e conceituais do processo administrativo}

O tratamento constitucional dispensado às regras de processo administrativo foi profundamente alterado pela publicação da $\mathrm{CF} / 88$. Entre outras garantias e direitos constitucionalmente assegurados, destaca-se a importância do devido processo legal administrativo, dos princípios da ampla defesa e do contraditório e do direito de recorrer na formação do sistema recursal administrativo.

Considerando-se esses pressupostos, a Lei Federal n. 9.784/99 assumiu a indispensável função de consolidação das normas processuais administrativas, sendo responsável pelo estabelecimento de diversas regras para o cabimento, processamento e julgamento dos recursos administrativos.

Assim, adotando-se a Lei Federal n. 9.784/99 como paradigma normativo das regras de processualidade administrativa no âmbito federal, elaborou-se uma tipologia descritiva dos recursos administrativos. Na segunda parte desse trabalho, são definidos quais os tipos de recursos administrativos existentes, suas principais características, as 
hipóteses de cabimento, os legitimados para apresentação, a competência para processamento e julgamento, os prazos, os efeitos que podem lhe ser atribuídos e as espécies de decisões deles resultantes. 


\title{
TIPOLOGIA DOS RECURSOS ADMINISTRATIVOS NA LEI FEDERAL N. 9.784/99: ESTABELECIMENTO DO PARADIGMA RECURSAL
}

\begin{abstract}
SUMÁRIO: 1. Recursos administrativos e outras espécies recursais; 1.1. Reconsideração; 1.2. Revisão; - 1.3. Recurso administrativo; 1.3.1. Recurso hierárquico próprio; 1.3.2. Recurso hierárquico impróprio; - 2. Elementos comuns dos recursos administrativos; 2.1. Gratuidade dos recursos administrativos: recolhimento de custas processuais e depósito recursal; 2.2. Legitimidade e competência; 2.3. Prazos; 2.4. Decisão em sede recursal; 2.4.1. Confirmação; 2.4.2. Modificação; 2.4.3. Anulação e revogação; 2.5. A reformatio in pejus na decisão recursal.
\end{abstract}

\section{Recursos administrativos e outras espécies recursais}

A Lei Federal n. 9.784/99, enquanto lei geral de processo administrativo, estabelece as regras de interposição, recebimento e processamento dos recursos administrativos na esfera dos entes públicos federais. Dessa forma, por meio da análise dos dispositivos normativos dessa lei de processo administrativo federal, os itens a seguir apresentarão a tipologia recursal e as principais características dos recursos administrativos e das demais espécies recursais.

\subsection{Reconsideração}

Em momento imediatamente anterior à interposição do recurso administrativo, o interessado inconformado com a decisão que lhe foi desfavorável tem a oportunidade de solicitar à própria autoridade que tomou essa decisão que a reconsidere. Trata-se do pedido de reconsideração, uma figura processual diferenciada denominada de sucedâneo recursal, cuja principal característica é "substituir a utilização do recurso apropriado" (JORGE, 2007, p.185).

Mesmo que seja adequado buscar auxílio no direito processual para compreender de maneira mais aprofundada toda a dimensão do pedido de reconsideração, deve-se ter em mente que esse instrumento processual está atualmente perdendo cada vez mais espaço nos processos civis em razão de uma opção mais vantajosa, o agravo de instrumento $^{71}$, fato que não se verifica no direito processual administrativo, já que é cada

\footnotetext{
${ }^{71}$ Segundo JORGE, “[c]om a interposição do agravo de instrumento diretamente no tribunal, não existe mais aquela lacuna anteriormente existente onde permitia-se que a parte provocasse o juiz monocrático e caso não desse resultado essa provocação que ele então interpusesse o recurso. Agora, prolatada a decisão e estando insatisfeita a parte, deve ela, no prazo legal, interpor o seu agravo de instrumento diretamente no Tribunal de Justiça. (2007, p.185)
} 
vez mais comum a presença de dispositivos normativos prevendo a possibilidade de se formular o pedido de reconsideração ${ }^{72}$. Desse modo, em função de suas características únicas e peculiares, o pedido de reconsideração será detalhadamente analisado, destacando-se especialmente sua importância para a técnica processual administrativa.

O pedido de reconsideração não se confunde com a reconsideração propriamente dita, pois enquanto o pedido de reconsideração é a petição por meio da qual o interessado, inconformado com a decisão adotada, provoca a autoridade administrativa a reexaminala (JORGE, 2007, p.185), a reconsideração é o ato administrativo resultante do acolhimento do pedido de reconsideração pela autoridade administrativa, cujo conteúdo é a alteração parcial ou total da decisão anteriormente proferida (MARRARA; NOHARA, 2009, p.369). Na verdade, o pedido de reconsideração é o requerimento que solicita uma segunda reflexão sobre as questões debatidas no processo administrativo, sendo seu objetivo fundamental buscar outra interpretação dos fatos, provas e justificativas apresentados para obter-se a substituição da decisão desfavorável por outra mais benéfica.

Note-se, portanto, que a ressignificação dos elementos constituintes de um processo administrativo necessariamente promoverá a expedição de outro ato administrativo decisório, substituto daquele que foi objeto da reconsideração, cujo teor pode ser parcialmente coincidente com o conteúdo da decisão original ou completamente distinto dele.

Observe-se o esquema abaixo:

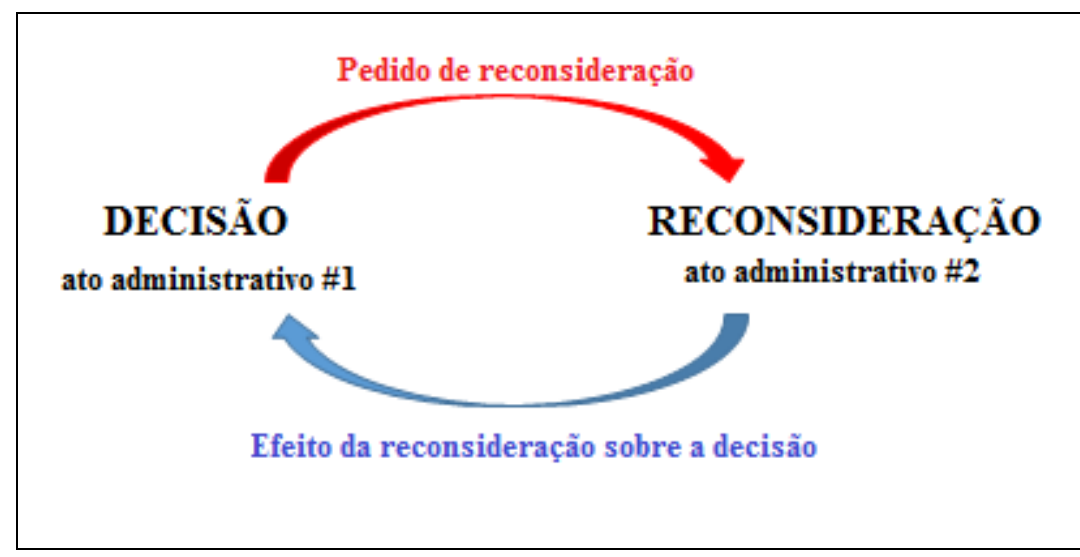

Figura 01: Representação esquemática do pedido de reconsideração Fonte: autoria própria

\footnotetext{
${ }^{72}$ Alguns exemplos: (i) art. 56, $§ 1^{\circ}$ da Lei Federal n. 9.784/99; (ii) art. 106 da Lei Federal n. 8.112/90; (iii) art. 109, III da Lei Federal n. 8.666/93.
} 
Trata-se de uma simplificação por meio de uma representação gráfica, com o objetivo de detalhar os aspectos mais relevantes da dinâmica entre a decisão e a reconsideração, considerando-se suas naturezas jurídicas de ato administrativo.

A legislação não determina expressamente os limites do pedido de reconsideração, não havendo impedimento, assim, para requerer-se o desfazimento do ato administrativo decisório tanto por motivos de legalidade quanto por razões de conveniência e oportunidade $^{73}$. Com efeito, por meio de uma interpretação ampliativa, pode-se compreender que o caput do art. 56 da Lei Federal n. 9.784/99 - dispositivo normativo cujo $\S 1^{\circ}$ faz menção ao pedido de reconsideração - ao determinar que "[d]as decisões administrativas cabe recurso, em face de razões de legalidade e de mérito", igualmente se refere ao pedido de reconsideração.

Se o pedido de reconsideração pode solicitar o controle da legalidade ou o reexame do mérito do ato administrativo, então qual a natureza jurídica da reconsideração: anulação ou revogação? Segundo DI PIETRO, a anulação é a modalidade de extinção do ato administrativo inválido em decorrência de vício de legalidade (2011, p.238) e a revogação é o desfazimento do ato administrativo válido por razões de conveniência e oportunidade (2011, p.252), assim, entendendo-se que a reconsideração pode assumir tanto a natureza de anulação quanto a de revogação, é mais adequado denominar a natureza jurídica da reconsideração como substituição, cujo efeito pode ser de anulação ou revogação dependendo do objeto sobre o qual recai a reconsideração. Note-se que quando a substituição assumir caráter de anulação, seus efeitos operarão ex tunc, ao passo que quando se tratar de revogação, em decorrência da decisão ser juridicamente válida, os efeitos serão de natureza $e x$ nunc $^{74}$.

Efetivamente, o pedido de reconsideração somente produzirá o efeito pretendido sobre a decisão se houver uma fundamentação realmente consistente dos motivos alegados, estejam eles relacionados a motivos de legalidade ou razões de conveniência e oportunidade. Nesse sentido, a argumentação deve fundamentar-se essencialmente nos

\footnotetext{
${ }^{73}$ Alguns autores, como MARRARA e NOHARA, entendem que o desfazimento da decisão por motivos de conveniência e oportunidade deve ser denominada de reforma (2009, p.369). Outros autores, como VELOSO, denominam o desfazimento por motivos de legalidade ou razões de conveniência e oportunidade de retratação (2012, p.177). Porém, haja vista que as legislações federais somente se referem ao termo reconsideração, não serão adotados nessa dissertação nenhuma outra terminologia.

${ }^{74}$ Note-se, há duas abordagens distintas e possíveis quanto a reconsideração. Enquanto ato administrativo, os efeitos da reconsideração sobre a decisão são analisados em relação ao plano de validade. Por sua vez, enquanto instrumento processual, os efeitos da reconsideração são examinados quanto a execução da decisão, i.e., efeito devolutivo e efeito suspensivo. Nesse primeiro momento, analisa-se a reconsideração somente sob a perspectiva do ato administrativo, sendo que questões relativas aos efeitos da reconsideração sobre a execução da decisão serão abordadas posteriormente.
} 
fatos e provas apresentados no decorrer do processo administrativo, estimulando a autoridade administrativa a reinterpretar esses elementos de forma a alcançar outra solução para o problema exposto.

Além dessa questão dos efeitos da reconsideração sobre a decisão, há outro ponto bastante relevante que merece uma reflexão mais aprofundada. Não há dúvidas de que o pedido de reconsideração pode abordar questões de legalidade e mérito, contudo é necessário avaliar se esse requerimento pode solicitar o reexame da decisão com base em novos fatos ou provas - não apresentados ao longo do processo administrativo.

O Ministério da Previdência Social disponibiliza aos cidadãos um serviço relativo à perícia médica nos casos de benefício por incapacidade previdenciário e, conforme descrição do próprio ente público:

O Pedido de Reconsideração é um serviço que permite ao segurado solicitar uma nova avaliação médica em função de não concordar com o indeferimento ou de diante da obtenção de novos elementos, que poderá ser realizado por qualquer perito médico, inclusive o responsável pela avaliação. (MINISTÉRIO DA PREVIDÊNCIA SOCIAL. Requerimento de Pedido de Reconsideração de Benefício por Incapacidade Previdenciário: PR. Disponível em: <http://agencia.previdencia.gov.br/e-aps/servico/423>. Acesso em 03 jan 2015)

$\mathrm{Na}$ hipótese acima, tem-se que o interessado poderá formular pedido de reconsideração em (i) razão de não concordar com o indeferimento da avaliação médica ou (ii) mediante a obtenção de novos elementos. A Súmula n. 182 do Superior Tribunal de Justiça estabelece a necessidade de se "atacar especificamente os fundamentos da decisão" como requisito essencial para a viabilidade do agravo (figura processual análoga ao pedido de reconsideração ${ }^{75}$ ), ou seja, não basta a simples irresignação como argumento para sustentar o requerimento que objetiva a reconsideração da decisão, mas é necessário que o interessado conteste cada um dos elementos constituintes da decisão de maneira

\footnotetext{
${ }^{75}$ Conforme "PROCESSUAL CIVIL. PEDIDO DE RECONSIDERAÇÃO NO AGRAVO EM RECURSO ESPECIAL RECEBIDO COMO AGRAVO REGIMENTAL. PRINCÍPIO DA FUNGIBILIDADE RECURSAL. FUNDAMENTO NÃO IMPUGNADO NAS RAZÕES DO AGRAVO REGIMENTAL. SÚMULA 182/STJ. 1. O pedido de reconsideração de decisões monocráticas legalmente previsto é o agravo regimental, cujo prazo para apresentação é de 5 dias, contados da publicação da decisão agravada. Assim, tendo em vista o princípio da fungibilidade recursal, recebo a petição de reconsideração como agravo regimental. 2. A leitura dos autos revela que o agravante não afastou o fundamento da decisão que negou provimento ao agravo, segundo o qual: a orientação jurisprudencial do STJ é no sentido de que a comprovação do pagamento do preparo do recurso especial deve ser feita no momento da interposição do recurso, nos termos da Súmula 187/STJ. 3. O agravo regimental que não impugna especificamente os fundamentos da decisão agravada não deve ser conhecido, nos termos da Súmula 182/STJ. 4. Agravo regimental não conhecido" (SUPERIOR TRIBUNAL DE JUSTIÇA. Pedido de Reconsideração no agravo em Recurso Especial n. 362203 MG 2013/0193139-8, Segunda Turma, Relator Ministro Mauro Campbell Marques, j. 07 nov 2013)
} 
fundamentada, apontando as irregularidades, incongruências ou eventuais ilegalidades. Para além da possibilidade de se contestar os fundamentos da decisão, o pedido de reconsideração igualmente poderá ser formulado com a finalidade de se apresentar novos elementos que ainda não haviam sido originalmente considerados no processo administrativo, seja porque inexistiam no momento da formação do convencimento ou pela impossibilidade de serem alegados naquela ocasião.

A dedução de argumentação jurídica nova com base em novos fatos ou provas pode representar meio bastante eficiente para impulsionar o convencimento da autoridade administrativa e promover a substituição da decisão por outra mais benéfica, porém não pode constituir mecanismo para violação do devido processo legal administrativo. Como, então, efetivar o devido processo legal administrativo na análise do pedido de reconsideração haja vista a ausência de regulamentação específica para esse requerimento e diante do prazo para a reconsideração pela autoridade administrativa ser, geralmente, muito curto quando comparado com outras diligências do processo administrativo?

O princípio do contraditório consiste na "garantia de participação processual como pressuposto de validade de toda a atividade instrutória” (MOREIRA, E. B., 2007, p.305), sendo que essa participação consiste na totalidade das manifestações processuais oferecidas pelas partes, na própria possibilidade de apresentação dessas manifestações, no dever de intimação da parte contrária e na possibilidade de apreciação dos fatos e provas apresentadas (MOREIRA, E. B., 2007, p.305). Por consequência, não “produzirá efeitos legítimos a 'prova' produzida unilateralmente pela Administração, nem tampouco aquela produzida parcialmente por um dos interessados, sem a respectiva intimação para que os demais possam participar do ato processual" (MOREIRA, E. B., 2007, p.307). Portanto, a validade do ato administrativo de reconsideração está diretamente vinculada à possibilidade de contraditório pela parte adversa, a quem deve ser permitida a manifestação quanto aos novos fatos e novas provas alegadas em sede de pedido de reconsideração. Essa manifestação, diante do prazo para reconsideração frequentemente ser escasso, poderá ser feita oralmente, vez que no processo administrativo vigora o princípio do formalismo moderado (BACELLAR FILHO, 2013, p.186), que garante que as formas não signifiquem obstáculo ao exercício da atividade administrativa e dos direitos individuais.

$\mathrm{O}$ ato administrativo de reconsideração editado sem considerar o devido processo legal administrativo e, por conseguinte, os princípios do contraditório e da ampla defesa apresentará vício de legalidade, devendo, portando ser anulado pela autoridade 
administrativa hierarquicamente superior ou por meio do controle jurisdicional. Além disso, ao interessado prejudicado pela reconsideração é permitida a apresentação de recurso administrativo à autoridade administrativa hierarquicamente superior.

Conforme analisado anteriormente, o art. 5. ${ }^{\circ}, \mathrm{XXXIV}$, "a" da CF/88 estabelece a todos os cidadãos "o direito de petição aos Poderes Públicos em defesa de direitos ou contra ilegalidade ou abuso de poder", assim, considerando sua natureza, o pedido de reconsideração deve ser compreendido como uma manifestação do direito de petição, pois proporciona ao cidadão inconformado com a decisão administrativa a oportunidade de peticionar pelo seu reexame com a finalidade de afastar-se ofensas a direitos fundamentais, sanar-se ilegalidades ou, até mesmo, evidenciar-se situações de desvio de poder e abuso de autoridade (GASPARINI, 1995, p.535). Em vista disso, não há obrigatoriedade da reconsideração estar expressamente prevista em dispositivo normativo específico para que o cidadão tenha a disposição esse instrumento processual, de tal modo que "[t]odo interessado que considere a decisão administrativa prejudicial aos seus direitos e interesses poderá solicitar a reconsideração da decisão" (MARRARA; NOHARA, 2009, p.368).

Enquanto manifestação concreta de um direito fundamental constitucionalmente garantido, o requerimento que solicita a reconsideração da decisão em sede processual administrativa não pode sofrer nenhuma espécie de impedimento, obstáculo, dificuldade ou constrangimento, hipótese que constitui ato de improbidade administrativa conforme previsão do art. 11 da Lei Federal n. 8.429/92, haja vista a violação dos princípios da Administração Pública. Em outras palavras, o recebimento, o processamento e a resposta devidamente fundamentada ao requerimento constituem dever inafastável da autoridade administrativa: "[a] possibilidade de reconsideração constitui uma etapa obrigatória do trâmite recursal (MARRARA; NOHARA, 2009, p.367).

Na prática, contudo, são comuns os relatos dos entraves criados ao pedido de reconsideração. Em alguns casos, o agente público, valendo-se da falta de conhecimento técnico do cidadão, convence a parte de que não é possível se formular um pedido de reconsideração quando não há previsão legal específica para tanto. Em outras situações, o agente público, por entender a reconsideração como uma ofensa pessoal ao "seu" poder e as suas capacidades decisórias, esvazia o sentido do pedido de reconsideração proferindo decisões cujo conteúdo são moralmente reprováveis, a exemplo de famoso caso ocorrido no judiciário, em que o juiz despachou a seguinte decisão: 
"[r]econsideração é o ato próprio de quem agiu impensadamente, sem maior reflexão ou convencimento, fosse para reconsiderar não teria decidido" (MIGALHAS, 2014).

A obrigação de recebimento-processamento-resposta do pedido de reconsideração deve ser compreendida dentro dos limites do direito de petição. Embora a autoridade administrativa esteja constitucionalmente vinculada ao exercício do juízo de reconsideração, garante-se ao agente público competente a discricionariedade no arbitramento da questão, sendo-lhe facultada, pois, a manutenção da decisão pelos seus próprios fundamentos ou a reconsideração devidamente motivada (DALLARI; FERRAZ, 2012, p.305).

Em síntese: (i) formular e apresentar o pedido de reconsideração constitui um direito fundamental do cidadão; (ii) deliberar acerca do pedido de reconsideração consiste em um dever do agente público; e (iii) a reconsideração é uma discricionariedade da autoridade administrativa.

Há outra questão que merece aprofundamento: pode a decisão sofrer reconsideração ainda que não haja provocação da autoridade administrativa por parte do interessado?

A atividade administrativa somente "será válida, legítima e justificável quando condizente, muito além da simples legalidade, com o sistema de princípios e regras delineado na Constituição, de maneira geral, e com os direitos fundamentais, em particular" (BINENBOJM, 2012, p.151), em outras palavras, a sujeição do exercício da função administrativa ao princípio da legalidade não se limita apenas a rígida observância das normas jurídicas, mas igualmente a "tutela da legítima confiança depositada pelos administrados nas condutas da Administração” (BINENBOJM, 2012, p.204) como meio de otimização dos princípios, regras, direitos e garantias constitucionalmente previstos. Por esse motivo, o controle interno visa a harmonização dos atos administrativos com o ordenamento jurídico, proporcionando a efetivação dos direitos fundamentais e princípios constitucionalmente garantidos.

A Súmula n. 473 do Supremo Tribunal Federal determina que

a administração pública pode anular os seus próprios atos, quando eivados de vícios que o tornem ilegais, porque deles não se originam direitos; ou revogá-los, por motivo de conveniência ou oportunidade, respeitados os direitos adquiridos, e ressalvada, em todos os casos, a apreciação judicial. ${ }^{76}$

\footnotetext{
${ }^{76}$ No mesmo sentido, a Súmula n.346 do Supremo Tribunal Federal estabelece que "a administração pública pode declarar a nulidade dos seus próprios atos".
} 
Trata-se da consagração do controle interno da atividade administrativa, que também pode ser exercido pelo próprio agente público responsável pela atividade sobre o resultado de sua atuação (MEDAUAR, 2012, p.52). Logo, há a possibilidade de sobreposição de funções, de modo que é verossímil a hipótese em que o agente público competente para o exercício da atividade e o agente controlador dessa atividade sejam a mesma autoridade administrativa.

São esses os fundamentos pelos quais se justifica o fato de que a reconsideração pode ocorrer tanto mediante provocação do interessado quanto espontaneamente ${ }^{77}$. Com efeito, o juízo espontâneo de reconsideração significa para a autoridade administrativa a oportunidade de refletir novamente a respeito da decisão adotada, corrigindo-a em caso de ilegalidade ou por razões de oportunidade e conveniência.

Não é por outro motivo que MEDAUAR (2012, p.53) explica que:

Embora na Administração Pública brasileira, em geral, o pedido de reconsideração seja desprezado pelas autoridades, com o pensamento de que o interessado, se quiser, 'vá reclamar seus direitos na Justiça', é um excelente meio para propiciar o autocontrole, para ouvir os interessados, para buscar atender aos anseios da população e, mesmo, para realizar a Justiça, visto que não somente o Poder Judiciário deve concretizá-la, mas também e sobretudo a Administração Pública, cada vez mais ampla, cada vez afetando mais direitos dos indivíduos.

Há duas maneiras de se elaborar o pedido de reconsideração, por meio de (i) petição autônoma endereçada diretamente à autoridade administrativa ou mediante (ii) interposição de recurso administrativo à autoridade hierarquicamente superior com pedido de reconsideração à autoridade administrativa que prolatou a decisão, que deve ser analisado antes do encaminhamento dos autos do processo administrativo à autoridade hierarquicamente superior (FORTINI; PEREIRA; CAMARÃO, 2012, p. 177).

Considerando-se que não ocorre a interrupção da fluência do prazo recursal pela apresentação do pedido de reconsideração, fato que será examinado em momento oportuno, geralmente o pedido de reconsideração é acostado ao recurso administrativo, vez que seu indeferimento automaticamente proporciona o encaminhamento do recurso administrativo à autoridade hierarquicamente superior.

\footnotetext{
77 Conforme WAMBIER (2006, p.384), “[e]m conclusão, pode dizer-se que o fato de haver ou não pedido de reconsideração é tecnicamente irrelevante. Em verdade, pois, ao pedido de reconsideração só pode seguir-se a alteração da decisão nos casos em que o juiz poderia, até mesmo sem o pedido, alterar sua decisão. E a alteração da decisão há de ser fundamentada, como se de outra decisão se tratasse, porque, na realidade é outra decisão"
} 
O fluxograma a seguir ilustra a dinâmica do pedido de reconsideração acostado ao recurso administrativo:

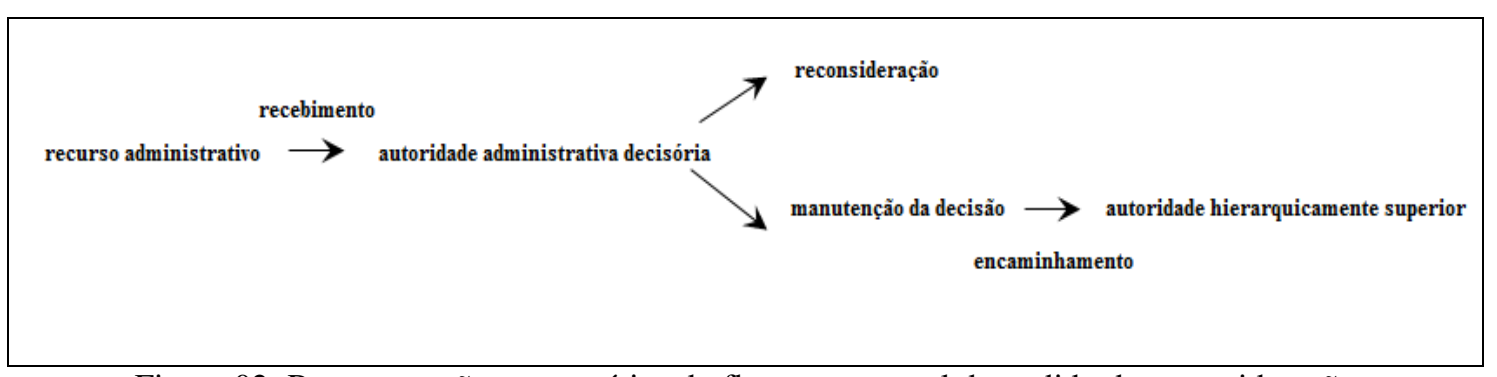

Figura 02: Representação esquemática do fluxo processual do pedido de reconsideração Fonte: autoria própria

Há duas hipóteses resultantes do juízo de reconsideração: (i) o deferimento integral ou parcial do pedido de reconsideração pelo acolhimento das razões alegadas torna prejudicado o recurso administrativo e (ii) o indeferimento do pedido de reconsideração pela manutenção dos próprios fundamentos da decisão automaticamente gera a obrigação da autoridade administrativa encaminhar o recurso à autoridade hierarquicamente superior. Note-se, ainda, que na primeira hipótese a reconsideração abre a possibilidade de apresentação de recurso administrativo pela parte prejudicada pela nova decisão, enquanto que na segunda situação, o encaminhamento do recurso administrativo à autoridade hierarquicamente superior consiste em "atividade vinculada, uma vez que não lhe cabe processar qualquer valoração sobre conveniência e oportunidade de sua conduta" (CARVALHO FILHO, 2013, pp.297-298).

Em relação ao prazo no pedido de reconsideração, há duas hipóteses a serem analisadas: (i) o prazo para protocolar o pedido de reconsideração; e (ii) o prazo para responder ao pedido de reconsideração.

A Lei Federal n. 9.784/99 não estabelece expressamente o prazo para formular-se requerimento de reconsideração, porém, tendo em vista que o art. 59 dessa legislação determina que, após a divulgação oficial da decisão da autoridade administrativa, a parte inconformada dispõe de dez dias corridos para interposição do recurso administrativo e em razão do pedido de reconsideração poder ser elaborado diretamente no corpo desse recurso, entende-se que o prazo para formular-se pedido de reconsideração deve ser de dez dias corridos. Não poderia ser de outra maneira. O pedido de reconsideração, enquanto sucedâneo recursal, não pode servir como instrumento de alongamento do prazo recursal, concedendo ao interessado prazo maior daquele que a legislação permite. 
Por sua vez, o prazo para a autoridade decisória responder ao pedido de reconsideração geralmente é de 05 (cinco) dias corridos, embora algumas legislações específicas atribuam um prazo maior para que ocorra essa reapreciação. A Lei Federal n. 9.784/99 determina que se a autoridade que proferiu a decisão não a reconsiderar no prazo de cinco dias, então deverá encaminhar o recurso administrativo à autoridade superior (art. $56, \S 1^{\circ}$ ), ou seja, de maneira implícita estabelece o prazo para a apreciação do pedido de reconsideração como sendo de cinco dias corridos. Diferentemente, a Lei Federal n. 8.112/90 determina que a autoridade decisória dispõe de trinta dias para decidir pelo seu deferimento ou indeferimento (art. 106, parágrafo único). Por sua vez, a Lei Federal n. 8.666/93 estabelece que o prazo para efetuar o pedido de reconsideração é de dez dias úteis contados a partir da intimação da decisão (art. 109, III), porém é silente a respeito do prazo para que ocorra a reavaliação, de modo que se poderá aplicar a regra geral determinada pela Lei Federal n. 9.784/99.

Caso o prazo não seja observado pela autoridade administrativa, deve-se proceder a apuração da infração funcional com a aplicação de penalidade disciplinar, por tratar-se de violação do dever legal da Administração Pública, ressalvados os casos em que se verifique a ocorrência de caso fortuito ou força maior a ser demonstrado pelo agente público (CARVALHO FILHO, 2013, p.298).

Ainda quanto a esse assunto, destaca-se a questão da fluência do prazo recursal e o efeito do pedido de reconsideração. Embora o interessado possua o direito de solicitar que sua pretensão seja reapreciada pela autoridade administrativa, o pedido de reconsideração não possui efeito interruptivo do prazo recursal (efeito suspensivo), cuja fluência inicia-se a partir da divulgação oficial da primeira decisão proferida, o que se justifica pelo fato de que o efeito suspensivo do pedido de reconsideração, ao transferir o início da fluência do prazo recursal para a prolação da segunda decisão, ensejaria a recuperação, a qualquer tempo, da possibilidade de se recorrer quando desatendida sua pretensão (DIAS, 2003, p.129) ${ }^{78}$. Nesse sentido, FAGUNDES explica que:

\footnotetext{
${ }^{78}$ Segundo DIAS, “[e]sse raciocínio, no entanto, não pode prevalecer quando a manifestação judicial traz prejuízo à outra parte, ou seja, quando o juiz, ao acolher pedido de uma das partes, causa prejuízo à outra. Nessa hipótese, o magistrado decidiu atentando exclusivamente nos argumentos e dados probatórios apresentados por uma parte, fazendo uso dos elementos de convicção que lhe foram trazidos por quem formulou o pedido. Acolhida a pretensão, a parte contrária, que resultou prejudicada ou se sentiu lesada pela decisão, não só pode, mas deve manifestar sua irresignação ao próprio juiz que lhe causou gravame. Nesse momento, o magistrado terá oportunidade de rever o que decidiu atentando nos argumentos trazidos pela parte que se sentiu atingida. Evidente que esse pedido revisional, formulado pela parte lesada, não se confunde com pedido de reconsideração, pois é trazida toda uma linha argumentativa da qual o magistrado não tinha conhecimento no julgamento anterior" (2003, p.130)
} 
"Nem seria razoável se entendesse diferentemente, pois assim não se procedesse, 'o interessado utilizaria o pedido de reconsideração como expediente para dilatar o prazo de recurso', que é peremptório e não admite ampliação nem convenção das partes a respeito" (FAGUNDES, 1946, p.71)

Ainda que o pedido de reconsideração não possa ser listado dentre as espécies de recursos administrativos, sua importância ultrapassa seu significado, vez que por meio do pedido de reconsideração há a possibilidade de efetivação do princípio da legalidade, princípio do interesse público, princípio da eficiência e princípio da finalidade. Embora pareça mais lógico que a autoridade administrativa não encontrará motivos numa mera provocação pela parte irresignada para modificar sua decisão, é sempre possível que durante o processo decisório a autoridade administrativa tenha cometido equívocos ou tenha negligenciado as provas apresentadas, de modo que ao reexaminar a questão decidida, possua motivos mais do que fundamentados para alterar o ato administrativo decisório, assim, identificando-se uma provável irregularidade, a autoridade administrativa poderá realinhar a decisão proferida de modo a efetivar os princípios da legalidade, interesse público e finalidade, o que poderá ser feito sem a necessidade de se proceder à tramitação do recurso interposto, o que significa relevante economia processual e a realização do princípio da eficiência (FERRAZ; DALLARI, 2012, p.305). Além disso, representa significativa economia de tempo e dinheiro tanto para os cidadãos envolvidos quanto para a Administração Pública (NERY JUNIOR, 2004, p.91).

Nesse sentido, FORTINI, PEREIRA e CAMARÃO explicam que

[e]m se tratando de processo administrativo, à vista do recurso que deveria ser julgado pela autoridade superior, poderá a autoridade que tomou a decisão contestada, em análise aos novos argumentos e julgando de outra forma o fato, alterar a sua decisão mesmo se o interessado não o requerer. É questão de economia processual e atendimento aos princípios da finalidade e do interesse público. Como antes de o processo seguir à autoridade superior, o recurso é protocolizado junto ao órgão em que atua a autoridade prolatora da decisão, essa terá novo acesso ao processo (2012, pp.176-177).

Diante dessa tamanha importância, deve o agente público se conscientizar do seu fundamental papel na concretização do pedido de reconsideração dentro do processo administrativo, manejando suas prerrogativas de forma a verdadeiramente efetuar o reexame da decisão, buscando por possíveis irregularidades e evidenciando quaisquer questões que possam ter sido por ele negligenciadas no processo decisório. 


\subsection{Revisão administrativa}

A revisão administrativa, a exemplo do pedido de reconsideração, não pode ser definida como um recurso administrativo em sentido estrito ${ }^{79}$, caracterizando-se como instrumento específico de controle administrativo, cuja finalidade é a verificação e correição da penalidade aplicada por determinada decisão (ato administrativo decisório) em razão do surgimento de informações novas e relevantes passíveis de demonstrar a ocorrência de desvio ou erro na atribuição da penalidade (MOREIRA, E. B., 2007, p.360). Em outras palavras, “[a] revisão é o caminho para que a Administração possa desfazer o ato ilegal ou injusto, seja porque a autoridade aplicou mal o direito ao fato, seja porque a instauração processual se revestiu de vício, foi incompleta ou mesmo deficiente." (CRETELLA JÚNIOR, 1972, p. 477)

A especificidade da revisão em relação aos recursos administrativos pode ser adequadamente demonstrada por meio do exame comparativo de seus requisitos essenciais. Observe-se, pois, a tabela a seguir:

\begin{tabular}{|c|c|c|}
\hline & Revisão & Recursos administrativos \\
\hline Aplicabilidade & processos sancionatórios & processos em geral \\
\hline Pressupostos & $\begin{array}{c}\text { fatos novos e } \\
\text { circunstâncias relevantes }\end{array}$ & $\begin{array}{c}\text { aspectos fáticos ou } \\
\text { jurídicos que demonstrem } \\
\text { a ilegalidade ou } \\
\text { inoportunidade e } \\
\text { inconveniência da decisão }\end{array}$ \\
\hline Interposição & voluntária ou oficial & voluntária \\
\hline Competência & originária & hierárquica \\
\hline Prazo & não há limite temporal & $10(\mathrm{dez})$ dias corridos \\
\hline Efeito & parcialmente devolutivo & $\begin{array}{c}\text { devolutivo e } \\
\text { excepcionalmente } \\
\text { suspensivo (art. 61, } \\
\text { parágrafo único Lei } \\
\text { Federal n. 9.784/99) }\end{array}$ \\
\hline Decisão & $\begin{array}{c}\text { não permite reformatio in } \\
\text { pejus }\end{array}$ & $\begin{array}{c}\text { permite a reformatio in } \\
\text { pejus }\end{array}$ \\
\hline $\begin{array}{l}\text { Relação com o processo } \\
\text { administrativo original }\end{array}$ & apensada ou autônoma & mesma relação processual \\
\hline
\end{tabular}

\footnotetext{
${ }^{79}$ A revisão administrativa não pode, porém, ser enquadrada como um sucedâneo recursal, tendo em vista que não possui função substitutiva em relação aos recursos administrativos. Adiante será possível constatar, na verdade, que a natureza da revisão é bastante distinta daquela dos recursos administrativos, especialmente em função de seu âmbito de aplicação, devendo ser melhor entendida como um mecanismo de controle administrativo interno.
} 
Diferentemente dos recursos administrativos, a revisão aplica-se exclusivamente aos processos sancionatórios, ou seja, processos cujo objetivo é a apuração de infrações administrativas e quando pertinente a aplicação de penalidades restritivas de direitos ${ }^{80}$ (MARRARA, NOHARA, 2009, p.413). A revisão administrativa ataca a penalidade inadequadamente aplicada ${ }^{81}$ - aquela impropriamente atribuída em razão de ilegalidade ou problemas relacionados ao mérito administrativo (MOREIRA, E. B., 2007, p. 360) resultando na substituição da decisão original por outra decisão com a penalidade aplicada modificada, motivo pelo qual se pode afirmar que a revisão "tem o escopo de alterar a situação jurídica decorrente de uma decisão definitiva na esfera administrativa" (FORTINI; PEREIRA; CAMARÃO; 2012, p. 217).

Enquanto a apresentação dos aspectos fáticos ou jurídicos que demonstrem a ilegalidade ou inoportunidade e inconveniência da decisão é suficiente para fundamentar a pretensão em sede de recurso administrativo, a simples alegação de injustiça da penalidade atribuída não constitui fundamento para a revisão administrativa, que requer a exposição de elementos novos ainda não apreciados no processo originário. Assim, estando a revisão administrativa "subordinada à existência concreta de fatos e pormenores inéditos ao processo e à decisão, absoluta e objetivamente desconhecidos dos interessados ou da Administração" (MOREIRA, E. B., 2007, p.360), a comprovação da existência de fatos novos ou circunstâncias relevantes suscetíveis de justificar a inadequação da penalidade aplicada assume-se como pressuposto do pedido revisional.

Todavia, deve-se destacar que o requisito "novidade" não possui uma conotação meramente cronológica, pois o fato não se caracteriza por sua recenticidade e sim por apresentar-se como um elemento de inovação no processo administrativo, ou seja, o fato é antigo no tempo, mas novo no instrumental probatório ${ }^{82}$. Desse modo, o fato novo deve

\footnotetext{
${ }^{80}$ Processo administrativo é uma nomenclatura genérica do instrumento por meio do qual a Administração Pública desenvolve a função administrativa. Há, desse modo, diversas espécies de processo administrativo, tais como o processo licitatório, o processo licenciatório ambiental, processo concessório de benefícios previdenciários, processo administrativo tributário, processo sancionatório, entre outros.

${ }^{81}$ Conforme MOREIRA, E. B., com "lastro nos fatos novos e circunstâncias relevantes, constata-se que o provimento aplicou mal a sanção, ou aplicou uma sanção errada" (2007, p.360)

${ }^{82}$ Os fatos novos podem ser ou não anteriormente conhecidos pelo acusado que os alega em sede revisional, desde que necessariamente desconhecidos pela autoridade administrativa no momento da decisão. Na hipótese de serem anteriormente conhecidos pelo acusado, é possível que tenham deixado de ser por ele apresentados por mero comodismo, descuido, descrença, dificuldade ou qualquer outra razão (COSTA, 2005, p.482), o que não significará obstáculo a sua alegação em âmbito revisional. Por sua vez, na hipótese de desconhecimento prévio dos fatos, ainda que esses elementos fossem impossíveis de serem conhecidos no decurso processual, "sua comprovação futura no âmbito administrativo - através da revisão - exige que
} 
necessariamente ter ocorrido em momento ou situação anterior à aplicação da penalidade enquanto que sua apresentação como elemento probatório deve obrigatoriamente ser efetuada posteriormente à decisão para qualificar-se como "novo" 83 .

Por sua vez, as circunstâncias relevantes configuram-se como os eventos ou condições que, por motivos de interesse público, determinam a modificação da penalidade originalmente aplicada. Diferentemente do que acontece no caso dos fatos novos, não há exigência quanto à anterioridade da ocorrência dos eventos ou condições caracterizáveis como circunstâncias relevantes, nem tampouco que esses eventos ou condições estejam diretamente relacionados com o objeto do processo administrativo, pois o elemento determinante da revisão fundamentada por circunstâncias relevantes é a efetivação da finalidade pública (MARRARA, NOHARA, 2009, p.415) ${ }^{84}$.

Além disso, é imprescindível que os fatos novos ou circunstâncias relevantes sejam dotados de potencialidade material e jurídica suficiente para romper definitivamente com as razões que motivaram a atribuição da penalidade, ou seja, é necessário que esses fatos ou circunstâncias sejam capazes de promover a modificação da convicção decisória da autoridade administrativa (COSTA, 2005, p.482).

A comprovação da existência de fatos novos ou circunstâncias relevantes suscetíveis de justificar a inadequação da penalidade aplicada configura-se como elemento constitutivo do núcleo de legalidade do ato administrativo revisional, razão pela qual a ausência desse elemento enseja o controle jurisdicional da revisão e, consequentemente, a sua declaração de nulidade. Nesse sentido, considere-se a seguinte ementa da decisão recentemente proferida pelo Superior Tribunal de Justiça, em que discute-se essa questão:

\footnotetext{
a sanção seja alterada, evitando-se, assim que uma restrição injusta da liberdade ou da propriedade dos cidadãos seja mantida" (MAHARA; NOHARA, 2009, p. 415).

${ }^{83}$ Apenas a título de curiosidade, pode-se citar como por exemplo a situação em que o verdadeiro autor da infração administrativa venha posteriormente a confessar a autoria dos fatos excluindo-se a responsabilidade do acusado (COSTA, 2005, p.482).

${ }^{84}$ De maneira exemplificativa, MARRARA e NOHARA propõem que imagine-se "que uma empresa tenha sido condenada, em razão da prática de infração a normas de direito do consumidor, à proibição de fabricação do produto X nos termos do art. 56, V, do CDC. Alguns meses depois, em razão de uma crise econômica de proporções inesperadas, todas as outras empresas que produzem o mesmo produto $\mathrm{X}$ vão à falência. Nesse caso, para proteger os próprios consumidores e evitar o banimento do produto do mercado, a autoridade federal pode, de ofício ou a pedido da empresa condenada, revisar a sanção administrativa que se impôs à empresa, permitindo-lhe novamente fabricar e comercializar o produto até então proibido por força da sanção administrativa. Veja-se que, nesse caso, o evento que permite a revisão não tem a ver diretamente com o processo condenatório. Não se trata de prova ou evidência nova, mas sim de uma alteração do cenário externo que torna a sanção administrativa totalmente inadequada" (2009, pp.415-416)
} 
ADMINISTRATIVO. PROCESSUAL CIVIL. DEMISSÃO. POLICIAL FEDERAL. PEDIDO DE REVISÃO ADMINISTRATIVA. ALEGAÇÃO DE FATOS NOVOS. INDEFERIMENTO. MANDADO DE SEGURANÇA. AUSÊNCIA DE PROVAS PRÉ-CONSTITUÍDAS. DILAÇÃO PROBATÓRIA. INVIABILIDADE. 1. Cuida-se de mandado de segurança impetrado contra o ato de Ministro de Estado que negou o pedido de revisão administrativa de demissão realizada mais de dez anos atrás; pela ordem se postula o reconhecimento de várias nulidades no processo administrativo disciplinar original. 2. Tanto as alegações de novos fatos, quanto as menções de nulidades do processo disciplinar original, foram feitas sem que fossem juntadas provas pré-constituídas necessárias para a sua aferição - o processo disciplinar original não foi juntado; assim, de plano, deve ser considerada a inviabilidade da ordem em razão da impossibilidade de dilação probatória. Precedente: MS 12.511/DF, Rel. Ministro Arnaldo Esteves Lima, Terceira Seção, DJ 25.10.2007, p. 121. 3. Ademais, deve ser considerado que a hipótese de revisão de processo administrativo disciplinar - com base em fato novo - é estreita. Se não for evidenciada e provada a existência de fato existente e não apreciado no passado, deve ser consignada a decadência da impetração. Precedentes: MS 17.704/DF, Rel. Ministro Benedito Gonçalves, Primeira Seção, DJe 9.4.2014; e MS 14.725/DF, Rel. Ministro Sebastião Reis Júnior, Terceira Seção, DJe 24.4.2012. Segurança denegada. (SUPERIOR TRIBUNAL DE JUSTIÇA. Mandado de Segurança n. 16.657/DF, Relator: Ministro Humberto Martins, j. 14 maio 2014. Disponível em <www.stj.jus.br>. Acesso em: 17 dez 2014) (grifo)

Portanto, a inadequação da penalidade verifica-se a partir do momento em que a decisão deixa de atingir suas finalidades públicas, se estabelecendo como vetor de restrição irregular de direitos individuais e coletivos por força do surgimento de fatos novos ou circunstâncias relevantes suficientemente capazes de promover a necessidade de revisão da decisão e da penalidade aplicada.

Outra questão importante se refere à interposição da revisão administrativa.

Levando-se em consideração que, no Estado Democrático de Direito, os princípios e normas jurídicas são a representação da vontade popular, para que seja possível que a função administrativa realize os interesses públicos identificados nesses princípios e normas, a atividade administrativa deve ser exercida em sujeição à legislação (PACCE, 2014, p.378) ${ }^{85}$. Entretanto, de nada "adiantaria condicionar a atuação estatal à estrita observância de regras legais, se sua atividade não fosse efetivamente controlada e seus desvios rigorosamente apurados e censurados com a devida proporcionalidade" (CARVALHO NETO, 2013, p.399), de modo que sempre que a autoridade administrativa

\footnotetext{
${ }^{85}$ Conforme MARQUES NETO (2010, pp.203-204), "[a] relação é direta com a própria noção de Estado de Direito. Este Estado, em contraposição ao Estado-Polícia característico do absolutismo, não apenas impõe normas jurídicas aos indivíduos. A lei subordina também a própria atuação do Estado, pois seus agentes a ela devem obediência. Quando a vontade individual dos governantes é substituída pela autoridade da norma geral, e o Estado passa a se submeter à ordem jurídica, o poder estatal passa a ser limitado e pode então ser controlado pelos seus destinatários. Vistas antes apenas como forma de se exigir obediência das pessoas às determinações do poder político, já agora na Idade Contemporânea - especialmente a partir dos marcos históricos das Revoluções Americana e Francesa - as normas jurídicas possibilitam disciplinar a organização e o funcionamento da máquina estatal. A ideia de controle da Administração Pública é então intrínseca a essa necessidade de proteger os delegatários do poder estatal contra o risco do seu exercício arbitrário".
} 
identificar que os atos e medidas adotados por seus agentes públicos possuam elementos que ensejem sua ilegalidade, deverá anulá-los e se concluir no sentido de sua inoportunidade e inconveniência, deverá revogá-los. (MEDAUAR, 2008, p. 130) ${ }^{86}$ : tratase do poder-dever de autotutela administrativa.

A revisão administrativa insere-se nessa lógica como o mecanismo prático de controle interno dos atos administrativos de caráter sancionatório ${ }^{87}$, razão que fundamenta a possibilidade - ao lado da interposição voluntária - de interposição oficial da revisão administrativa (revisão administrativa ex officio). Por isso, diante da identificação da ilegalidade ou inadequação da penalidade aplicada, a autoridade administrativa - ainda que não tenha ocorrido a provocação por parte do interessado ${ }^{88}$ deverá instaurar novo processo administrativo, de caráter revisório, com a finalidade da correição dessa penalidade.

\footnotetext{
${ }^{86}$ Esse entendimento está igualmente consignado nas súmulas 346 e 473 do Supremo Tribunal Federal. Contudo, vale lembrar que o art. 54 da Lei Federal n. 9.784/99 limitou temporalmente o direito da Administração Pública de anular os atos administrativos de que decorram efeitos favoráveis para os destinatários em 5 anos, como demonstrado na ementa do mandado de segurança a seguir:

"ADMINISTRATIVO. MANDADO DE SEGURANÇA. ANISTIADO POLÍTICO. PRESTAÇÃO MENSAL, PERMANENTE E CONTINUADA. REVISÃO DO ATO DE CONCESSÃO. PODER DE AUTOTUTELA ADMINISTRATIVA. ART. 54, $\S 2^{\circ}$, DA LEI N. ${ }^{\circ}$ 9.74/99. DECADÊNCIA. TRANSCURSO DE LAPSO TEMPORAL SUPERIOR AO QUINQUÍDIO LEGAL. 1 . O art. 54, da Lei 9.784/99, ao disciplinar o processo administrativo, estabeleceu o prazo de cinco anos para que pudesse a Administração revogar os seus atos. 2. A despeito de a Administração Pública estar adstrita à observância do princípio da legalidade, por força do art. 37, da Constituição Federal, deve o poder público observar outros princípios, notadamente o da segurança jurídica, corolário do Estado Democrático de Direito, previsto no art. $1^{\circ}$ da Constituição Federal. Precedente: (MS 9112/DF, Rel. Ministra ELIANA CALMON, CORTE ESPECIAL, DJ 14/11/2005). 3. A antiga jurisprudência do Supremo Tribunal Federal firmava o entendimento de que os atos administrativos inválidos poderiam ser revistos pela autoridade administrativa em nome do princípio da legalidade, ao fundamento de que os atos eivados de vícios não poderiam produzir efeitos. Nessa linha de raciocínio é que foram editadas as Súmulas 346 e 473, do STF. 4. Com a edição da Lei n. ${ }^{\circ}$ 9.784/99, a jurisprudência passou a reconhecer que a invalidação dos atos administrativos sujeitase a prazo decadencial, por aplicação expressa do art. 54, que assim dispõe: Art. 54. O direito da Administração de anular os atos administrativos de que decorram efeitos favoráveis para os destinatários decai em cinco anos, contados da data em que foram praticados, salvo comprovada má-fé. § 1o No caso de efeitos patrimoniais contínuos, o prazo de decadência contar-se-á da percepção do primeiro pagamento. § 2o Considera-se exercício do direito de anular qualquer medida de autoridade administrativa que importe impugnação à validade do ato. 3. É que a segurança jurídica, como subprincípio do Estado de Direito, assume valor ímpar no sistema jurídico, cabendo-lhe papel diferenciado na realização da própria ideia de justiça material. [...]" (SUPERIOR TRIBUNAL DE JUSTIÇA. Mandado de Segurança n. 15330 DF 2010/0096599-1, Relator: Min. Luiz Fux, j. 13 dez 2010) (grifo)

${ }^{87}$ MEDAUAR explica que o controle interno é a fiscalização que a própria Administração Pública "exerce sobre os atos e atividades de seus órgãos e das entidades descentralizadas que the são vinculadas" (2012, p.49), podendo ser denominado de autocontrole, quando exercido pelo próprio agente público que editou o ato (2012, p.52), ou controle hierárquico, quando a verificação seja efetuada por autoridades superiores $(2012$, p.54).

${ }^{88}$ Imprescindível, contudo, a participação nesse novo processo dos interessados e terceiros cuja esfera jurídica seja por ele atingida, pois a revisão, enquanto manifestação da função administrativa, está submetida à todos os princípios constitucionais e infraconstitucionais do processo administrativo, especialmente ao devido processo legal administrativo. Portanto, o processo de revisão administrativa que se desenvolver sem ter sido adequadamente informado aos interessados será manifestamente ilegal.
} 
O processo sancionatório, distintamente daquilo que sua própria denominação possa sugerir, possui primordialmente a finalidade de apuração de ocorrência de conduta violadora do ordenamento jurídico, podendo ou não resultar em aplicação de penalidade (NOHARA, 2013, p.280). Portanto, tão logo apresentado o resultado dessa apuração (e, nos casos em que for pertinente, aplicada a penalidade), extingue-se o processo administrativo, de forma que, diversamente daquilo sustentado por CARVALHO FILHO (2013, p.320), tanto no caso de interposição de ofício quanto na situação em que houver apresentação de requerimento pelo interessado, haverá instauração de novo processo administrativo. Note-se, porém, que esse novo processo administrativo revisional instaurado poderá ser apensado ao processo original e decidido considerando-se o processo administrativo globalmente.

A legitimidade para interposição oficial da revisão administrativa é primariamente da própria autoridade decisória e subsidiariamente da autoridade hierarquicamente superior, por sua vez, a legitimidade para interposição de revisão administrativa voluntária é primariamente do cidadão apenado e subsidiariamente de seus sucessores.

Considerando que a interposição oficial da revisão administrativa corresponde ao exercício do poder-dever de autotutela, a legitimidade para sua apresentação não pode se restringir exclusivamente a uma ou outra autoridade administrativa, podendo ser desempenhada por todo e qualquer agente público que verificar a irregularidade na atribuição da penalidade. Todavia, por questões de celeridade processual e eficiência, a legitimidade é preliminarmente da autoridade decisória, pois, estando mais informado quanto ao desenvolvimento do caso, o agente público competente para processamento e julgamento do processo administrativo tem mais condições de tomar conhecimento do aparecimento de fatos novos ou circunstâncias relevantes. A legitimidade subsidiária da autoridade hierarquicamente superior, por sua vez, não pode ser descartada, em decorrência do próprio poder hierárquico, que obriga os agentes públicos alocados em funções de supervisão dentro do órgão ou em outros entes públicos responsáveis pela supervisão das atividades dos entes públicos hierarquicamente inferiores ao controle dos atos administrativos, fiscalizando e corrigindo as irregularidades na aplicação da penalidade ou readequando a sanção em razão de superveniência de fatos ou circunstâncias.

Não há divergência quanto ao fato de que a legitimidade para apresentação da revisão administrativa por requerimento é do cidadão - considerando-se cidadão tanto a pessoa física como a pessoa jurídica sujeito passivo do processo administrativo 
sancionatório - sobre o qual recaiu a aplicação da penalidade, de maneira que há apenas que se considerar a questão quanto à legitimidade dos sucessores do cidadão apenado. Haja vista que os efeitos da aplicação da penalidade determinada pela decisão administrativa não estão limitados apenas às esferas jurídica e moral, mas igualmente podem atingir o âmbito patrimonial do cidadão apenado - como ocorre nas penalidades de cassação de aposentadoria e destituição do cargo em comissão ou função comissionada $^{89}$ - torna-se possível estender a legitimidade para interposição voluntária da revisão administrativa subsidiariamente aos sucessores nas situações de impossibilidade ou ausência do cidadão apenado ${ }^{90}$, pois, conforme explica VELOSO:

mesmo após o falecimento da pessoa punida, seus sucessores podem conseguir provas da inocência. E mais do que o conserto moral da decisão, em vários casos há efeitos pecuniários, pois as promoções e quitações das diferenças podem beneficiar, de forma direta, até mesmo os sucessores da pessoa que foi injustamente punida em outros tempos (2012, p.190).

A competência para o processamento da revisão administrativa é, em regra, originária, ou seja, da própria autoridade administrativa que originalmente proferiu a decisão sancionatória ${ }^{91}$, ainda que se trate de pedido revisional apresentado pela autoridade hierarquicamente superior.

$\mathrm{Na}$ verdade, o elemento indutor da competência para processamento da revisão administrativa é sempre a decisão sancionatória - considerada aquela que efetivamente determina a aplicação da penalidade - e não a posição hierárquica da autoridade administrativa $^{92}$. Veja-se, pois, as consequências práticas dessa regra para a estrutura decisória do processo administrativo:

\footnotetext{
${ }^{89}$ As penas de cassação de aposentadoria e destituição do cargo em comissão ou função comissionada, por sua vez, são aplicadas quando presentes as mesmas circunstâncias que ensejam a aplicação da penalidade de demissão. Sua finalidade, contudo, não é reeducar os afligidos com a punição, pois esses já não se encontram em exercício de cargo público. No caso do servidor aposentado, o objetivo é fazer cessar o pagamento dos seus proventos como consequência do ato irregular cometido quando em atividade no serviço público (FREITAS, 1999, p.125).

${ }^{90}$ Nesse sentido o inciso I do parágrafo único do art. 278 da Lei Complementar n.46/94 estabelece que: "I -[a revisão de que trata este artigo poderá ser requerida] em caso de falecimento, ausência ou desaparecimento do servidor público, por qualquer pessoa da família”

${ }^{91}$ De maneira exemplificativa, cita-se o consignado no art. 281 da Lei Complementar n.46/94:

“Art. 281. O requerimento de revisão do processo será dirigido ao chefe do Poder competente, o qual, se autorizar a revisão, encaminhará o pedido ao órgão processante da entidade onde se originou o processo administrativo-disciplinar"

92 Corroborando com esse entendimento, o art. 285 da Lei Complementar n.46/94 estabelece que "[o] julgamento [da revisão] caberá à autoridade que aplicou a penalidade, nos termos do art. 246".
} 


\begin{tabular}{|c|c|}
\hline Fluxo decisório & $\begin{array}{l}\text { Autoridade } \\
\text { competente }\end{array}$ \\
\hline $\begin{array}{l}\text { processo administrativo sancionatório } \rightarrow \text { decisão } \\
\text { sancionatória }\end{array}$ & inicial \\
\hline $\begin{array}{c}\text { processo administrativo sancionatório } \rightarrow \text { decisão } \\
\text { sancionatória } \rightarrow \text { recurso administrativo } \rightarrow \text { decisão recursal } \\
\text { (indeferimento do pedido) }\end{array}$ & inicial \\
\hline $\begin{array}{c}\text { processo administrativo sancionatório } \rightarrow \text { decisão } \\
\text { sancionatória } \rightarrow \text { recurso administrativo } \rightarrow \text { decisão recursal } \\
\text { (deferimento do pedido com modificação parcial ou total } \\
\text { da decisão sancionatória) }\end{array}$ & hierárquica \\
\hline
\end{tabular}

Analisando as possibilidades de fluxo decisório no processo administrativo, é possível concluir que a apresentação de recurso administrativo não é condição suficiente para ocasionar deslocamento da competência do processamento da revisão administrativa para a autoridade hierarquicamente superior, pois somente nos casos em que ocorrer a modificação da decisão sancionatória em razão do deferimento do pedido recursal é que a autoridade competente para o processamento da revisão administrativa será outra que não a que originalmente determinou a aplicação da penalidade (MAHARA; NOHARA, 2009, p.414).

Não há limitação temporal quanto à possibilidade de interposição da revisão administrativa, em decorrência, fundamentalmente, da persecução de dois objetivos práticos: (i) a proteção aos direitos e garantias fundamentais do cidadão apenado e (ii) a satisfação dos interesses públicos ${ }^{93}$. Portanto, ainda que a apreciação da revisão administrativa venha a resultar no indeferimento do pedido, a autoridade administrativa não pode se eximir da prestação do juízo revisional sob a alegação de decurso do prazo prescricional (CARVALHO FILHO, 2013, p.333).

Excetuando a regra geral dos processos administrativos, a revisão administrativa necessariamente não admite a decisão pelo agravamento da penalidade originalmente aplicada, pois a natureza sancionatória de revisão orienta a realização da segurança jurídica e da estabilidade das relações jurídicas (BUENO, 2006, p.214). Assim, "a pior situação que o recorrente pode sofrer é a que decorre do indeferimento do pedido revisional e a manutenção da sanção originalmente imposta” (CARVALHO FILHO, 2013, p.337).

\footnotetext{
${ }^{93}$ Em razão de sua natureza principiológica, a determinação consignada no art. 65 da Lei Federal n. 9784/99 não precisaria estar expressamente positivada, configurando-se, pois, apenas como um reforço normativo (MAHARA; NOHARA, 2009, p. 417).
} 


\subsection{Recurso administrativo}

Diferentemente daquilo que se observa nas demais disciplinas processuais jurídicas, o direito processual administrativo apresenta tão somente uma categoria de instrumento recursal, denominada de recurso administrativo. Essa categoria, por seu turno, compõese exclusivamente de duas variedades distintas: (i) o recurso hierárquico próprio e (ii) o recurso hierárquico impróprio ${ }^{94}$.

Com vistas à satisfação de finalidades meramente didáticas, inicialmente serão estudadas as peculiaridades de cada uma dessas variedades para, então, examinar-se os elementos comuns aos dois tipos de recursos administrativos.

\subsubsection{Recurso hierárquico próprio}

O controle hierárquico - entendido como resultado do poder hierárquico que fundamenta a organização da atividade administrativa (MEIRELLES, 2006, p.670) - é desenvolvido pelas autoridades superiores com a finalidade de ordenar, coordenar, orientar, fiscalizar e, eventualmente, corrigir o exercício da atividade administrativa das autoridades inferiores $^{95}$. Justamente em razão dessa relação de subordinação dos agentes públicos inferiores aos agentes públicos superiores é que o controle hierárquico somente se verifica dentro da estrutura organizacional verticalmente escalonada de um mesmo órgão, não podendo se conceber controle hierárquico entre autoridades administrativas pertencentes a diferentes entes públicos (MARQUES NETO, 2010, p.214) ${ }^{96}$.

Dentro da lógica do controle hierárquico, o recurso hierárquico próprio é o mecanismo responsável por impulsionar a fiscalização pela autoridade superior

\footnotetext{
94 "Referentemente aos recursos administrativos, tanto a legislação (Leis n os 9.784/99, 8.666/93 entre outras) como a doutrina e a jurisprudência têm afirmado e reconhecido a existência dos chamados "recursos hierárquicos" que compreendem os pedidos de revisão de decisões administrativas endereçados a um órgão julgador superior, geralmente da própria administração (recurso hierárquico próprio), podendo ser dirigidos à um órgão estranho à administração que proclamou o ato recorrido, desde que esse órgão tenha competência legal para reapreciar as decisões administrativas (recurso hierárquico impróprio)" (SUPERIOR TRIBUNAL DE JUSTIÇA. Recurso ordinário em Mandado de segurança RMS n.15324 MS 2002/0118532-7, Relator Ministro Paulo Gallotti, j. 13 maio 2003. Disponível em <www.stj.jus.br>. Acesso em 10 fev 2015.)

95 "Numa estrutura hierarquizada, com escalonamento de poderes, o controle é exercido pelos superiores. Como consequência lógica dessa hierarquia, decorre, para o superior, o poder de dar ordens, de expedir instruções, circulares, ordens de serviço, de avocar, organizar serviços, comandar a execução de atividades dos subordinados (inclusive revogando ou anulando decisões que por esses tenham sido tomadas). É o controle que se exerce internamente a um órgão público, mediante a ascendência do superior hierárquico sobre seus subordinados" (MARQUES NETO 2010, p. 214).

96 As relações de supervisão entre entes públicos serão tratadas oportunamente, quando se abordará a questão do recurso hierárquico impróprio.
} 
competente da forma e do conteúdo do ato administrativo decisório praticado pela autoridade administrativa inferior. Essa fiscalização motivada pela apresentação do recurso hierárquico próprio deverá recair tanto sobre os aspectos de legalidade quanto sobre o mérito do ato decisório, podendo modificar a decisão do subordinado tanto no sentido do atendimento do pedido do interessado, quanto promovendo o agravamento da situação jurídica do recorrente quando na defesa e promoção dos interesses públicos (MEDAUAR, 2012, p.55).

O recurso hierárquico próprio é o recurso administrativo propriamente dito - o recurso administrativo por excelência - e consiste em um pedido à autoridade superior competente de reforma da decisão originalmente proferida pela autoridade administrativa inferior (DALLARI; FERRAZ, 2012, p. 281) ${ }^{97}$. Assim, o recurso hierárquico próprio deve ser compreendido como o meio pelo qual o interessado que não se conformou com a decisão que lhe foi desfavorável pode solicitar à autoridade superior competente a reapreciação do ato administrativo decisório (MARRARA; NOHARA, 2009, p. 362$)^{98}$.

Entretanto, é importante salientar que o recurso hierárquico próprio não representa a transposição do recurso judicial para a esfera processual administrativa, pois apresenta diversas peculiaridades que o singularizam como um instrumento tipicamente administrativo: orientando-se pela manutenção da legalidade administrativa e pela efetivação do interesse público, o recurso hierárquico próprio, entre outras coisas, autoriza a apresentação de elementos inicialmente não alegados, a produção de novas provas e o reexame da matéria de fato (DI PIETRO, 2011, p.739), hipóteses impossíveis de ocorrerem em sede de recurso judicial.

O art. 56 da Lei Federal n. 9.784/99 introduziu a possibilidade de interposição de recurso hierárquico próprio no âmbito do processo administrativo federal ao determinar o cabimento de recurso contra decisões administrativas em razões de legalidade e de

\footnotetext{
97 "Como se depreende, o recurso hierárquico é um recurso administrativo, agitado no âmbito da Administração Pública tratando-se de uma garantia graciosa que se situa e é dirigido aos seus próprios órgãos, característica que o distingue do recurso contencioso. Contra as decisões administrativas emanadas por pessoas ou órgãos do Poder Judiciário é sempre possível o recurso hierárquico próprio, dirigido à autoridade ou ao órgão superior da sua administração, e o impróprio, desde que, neste caso, previsto por norma legal 'que indique as condições de sua utilização, a autoridade ou órgão incumbido do julgamento e os casos em que tem cabimento' segundo os ensinamentos doutrinários acima transcritos" (SUPERIOR TRIBUNAL DE JUSTIÇA. Recurso ordinário em Mandado de segurança RMS n.15324 MS 2002/0118532-7, Relator Ministro Paulo Gallotti, j. 13 maio 2003. Disponível em <www.stj.jus.br>. Acesso em 10 fev 2015.)

98 “A visão mais apropriada para o termo recurso administrativo é a que o entende unicamente como pedido de reexame da decisão objeto da discórdia, por parte da autoridade hierarquicamente superior à que o prolatou" (VELOSO, 2012, p.179).
} 
mérito $^{99}$ (art. 56, caput) a ser encaminhado à apreciação da autoridade superior (art. 56, $\S 1^{\circ}$ ). Tal previsão representa mais um instrumento de consolidação do direito de petição (art. $5^{\circ}, \mathrm{XXXIV}, a \mathrm{CF} / 88$ ) e significativo avanço nas relações entre os agentes públicos e os cidadãos, pois autoriza a manifestação da insatisfação com a prática de ato administrativo decisório desfavorável por meio da indicação de possíveis irregularidades, incongruências ou ilegalidades na decisão proferida, auxiliando a autoridade administrativa no cumprimento do poder-dever de autotutela administrativa (FORTINI; PEREIRA; CAMARÃO; 2012, p. 199) e promovendo a defesa dos interesses públicos na via processual administrativa federal.

Não haveria, contudo, obrigatoriamente a necessidade da Lei Federal n. 9.784/99 ter expressamente previsto o cabimento de recurso hierárquico próprio, em função do recurso hierárquico próprio ser uma manifestação do direito de petição (art. $5^{\circ}$, XXXIV, a CF/88) e do controle hierárquico. Sua aplicação é geral, sendo admitido sempre, ressalvadas as hipóteses expressamente previstas em lei específica (BARROS JÚNIOR, 1948, p.50).

Demais detalhes a respeito dos recursos administrativos - hierárquico próprio e hierárquico impróprio - serão analisados em itens específicos.

\subsubsection{Recurso hierárquico impróprio}

O controle administrativo também pode ser decorrente da relação institucional entre os entes da administração direta e indireta. Nessa modalidade de controle administrativo, o ente público controlador (administração direta) verifica a atividade do ente público controlado (administração indireta) em razão do poder de supervisão que lhe é normativamente conferido ${ }^{100}$.

Nessa perspectiva de supervisão dos entes públicos da administração indireta pelos entes públicos da administração direta, o recurso hierárquico impróprio insere-se como o mecanismo prático - expressamente previsto por norma jurídica específica - de controle da decisão da autoridade competente na administração indireta pela autoridade competente para supervisão na administração direta. Portanto, o recurso hierárquico

\footnotetext{
${ }^{99}$ A interpretação do art. 56 da Lei Federal n. 9.784/99 evidencia a intenção do legislador em determinar que o recurso hierárquico próprio serve tanto ao reexame dos atos decisórios vinculados quanto dos atos decisórios discricionários (BUENO, 2006, p.194)

100 "O vetor institucional do controle é aquele que se exerce mediante a tutela de um ente por outro. Nele não há propriamente hierarquia, mas verificação do cumprimento dos objetivos institucionais que justificam a criação do ente. Normalmente o controle institucional se exerce nos termos da lei e por meio dos órgãos da Administração central sobre os entes da Administração indireta” (MARQUES NETO, 2010, p.214)
} 
impróprio pode ser definido como a petição de caráter recursal, cujo endereçamento é necessariamente direcionado à autoridade da administração direta competente para a supervisão da atividade decisória da autoridade da administração indireta, com a finalidade de verificação e correição da decisão administrativa emitida (GUERRA, 2006, p.492). Os requisitos fundamentais para a caracterização do recurso hierárquico impróprio são: (i) a ausência de relação hierárquica entre os entes controlador e controlado, (ii) existência de norma jurídica expressamente prevendo a sua possibilidade de interposição, (iii) necessidade de fiscalização e correição (controle) da atividade administrativa (decisão administrativa) do ente público controlado.

Todavia, o recurso hierárquico impróprio, ainda que expressamente previsto, é um instrumento recursal de uso meramente excepcional, exatamente em razão da inexistência de relação hierárquica entre as autoridades administrativas envolvidas na apreciação da questão apresentada (CRETELLA JÚNIOR, 1970, p.22). ${ }^{101}$

Abaixo, verifica-se um quadro comparativo que procura expressar as principais divergências entre os recursos hierárquicos próprios e os recursos hierárquicos impróprios.

\begin{tabular}{|c|c|c|}
\hline & $\begin{array}{c}\text { Recurso hierárquico } \\
\text { próprio }\end{array}$ & $\begin{array}{c}\text { Recurso hierárquico } \\
\text { impróprio }\end{array}$ \\
\hline $\begin{array}{c}\text { Distribuição de } \\
\text { competência }\end{array}$ & desconcentração & supervisionalionão \\
\hline Competência & hierárquica & indispensável \\
\hline Previsão normativa & dispensável & $\begin{array}{l}\text { confirmar, modificar, anular } \\
\text { ou revogar a decisão } \\
\text { recorrida }\end{array}$ \\
\hline Finalidade & $\begin{array}{l}\text { confirmar, modificar, anular } \\
\text { ou revogar a decisão } \\
\text { recorrida }\end{array}$ & \\
\hline
\end{tabular}

Tabela 04: Comparação entre o recurso hierárquico próprio e o recurso hierárquico impróprio Fonte: autoria própria

O recurso hierárquico impróprio insere-se na lógica da descentralização administrativa, em que a distribuição de competências para a atividade administrativa é feita de uma pessoa jurídica para outra (DI PIETRO, 2011, p.420). Embora os recursos administrativos geralmente sejam apresentados na intimidade da uma mesma pessoa jurídica, a lei poderá determinar "que da decisão de uma pessoa jurídica cabe recurso para

\footnotetext{
${ }^{101}$ Nesse sentido, os "recursos administrativos são propostos na intimidade de uma mesma pessoa jurídica, por isto são chamados de recursos hierárquicos. Se, todavia, a lei previr que da decisão de uma pessoa jurídica cabe recurso para a autoridade encartada em outra pessoa jurídica, o recurso será, em tal caso, denominado de recurso hierárquico impróprio" (MELLO, C., 2002, p.129)
} 
autoridade encartada em outra pessoa jurídica" (MELLO, C., 2002, p.129), situação em que o recurso administrativo será denominado de recurso hierárquico impróprio.

Ainda em relação à questão da descentralização, é fundamental destacar que a distribuição de competência para fins de supervisão e cabimento de recurso administrativo impróprio deve limitar-se somente ao âmbito administrativo, motivo pelo qual não será possível o cabimento de recurso administrativo endereçado a outro Poder, conforme demonstrado a seguir:

\begin{abstract}
RECURSO ORDINÁRIO - MANDADO DE SEGURANÇA - CONSELHO DE CONTRIBUINTES DO ESTADO DO RIO DE JANEIRO - RECURSO HIERÁRQUICO - SECRETÁRIO DE ESTADO DA FAZENDA DO ESTADO EXPRESSA PREVISÃO LEGAL - LEGALIDADE - PRECEDENTES. A previsão de recurso hierárquico para o Secretário de Estado da Fazenda quando a decisão do Conselho de Contribuintes do Estado do Rio de Janeiro for prejudicial ao ente público não fere os princípios constitucionais da isonomia processual, da ampla defesa e do devido processo legal, porque é estabelecida por lei e, ao possibilitar a revisão de decisão desfavorável à Fazenda, consagra a supremacia do interesse público, mantido o contraditório. Nesse sentido, assevera Hely Lopes Meirelles que os recursos hierárquicos impróprios "são perfeitamente admissíveis, desde que estabelecidos em lei ou no regulamento da instituição, uma vez que tramitam sempre no âmbito do Executivo que cria e controla essas atividades. O que não se permite é o recurso de um Poder a outro, porque isto confundiria as funções e comprometeria a independência que a Constituição da República quer preservar". Além disso, o contribuinte vencido na esfera administrativa sempre poderá recorrer ao Poder Judiciário para que seja reexaminada a decisão administrativa. Já a Fazenda Pública não poderá se insurgir caso seu recurso hierárquico não prospere, uma vez que não é possível a Administração propor ação contra ato de um de seus órgãos. Recurso não provido. (SUPERIOR TRIBUNAL DE JUSTIÇA. Recurso Ordinário em Mandado de Segurança n. 12386 RJ 2000/0092265-0. Segunda Turma. Relator: Ministro Franciulli Netto, j. 19 fev 2004) (grifo)
\end{abstract}

O recebimento do recurso hierárquico impróprio é sempre desempenhado pela autoridade prolatora da decisão administrativa, que não possui, contudo, a faculdade de exercer juízo de admissibilidade quanto ao recurso administrativo interposto. Assim, a despeito dos motivos de sua apresentação, o recurso hierárquico impróprio deve sempre ser protocolado junto à autoridade decisória, que exercerá juízo de reconsideração antes de seu encaminhamento à autoridade competente da pessoa jurídica encarregada pela supervisão (MARRARA; NOHARA, 2009, p. 367). Em razão dessa atribuição especial de competência do recurso hierárquico impróprio, seu processamento necessariamente acontecerá em duas pessoas jurídicas distintas ${ }^{102}$.

Assim, no caso do recurso hierárquico impróprio, a competência não é hierarquicamente determinada, pois o elemento nuclear para a delimitação da

\footnotetext{
$102 \mathrm{O}$ deferimento do pedido de reconsideração interrompe o fluxo do recurso hierárquico impróprio.
} 
competência para sua apreciação é a relevância da temática debatida em razão do interesse público envolvido na questão. $\mathrm{Na}$ verdade, o fato do recurso hierárquico impróprio depender de previsão normativa reforça essa lógica de proteção do interesse público, deslocando o processamento e julgamento da questão para entes públicos mais próximos do poder central - situados na própria administração direta - com a finalidade de (i) verificação do cumprimento dos objetivos institucionais, (ii) proteção dos direitos e garantias individuais contra arbitrariedades, (iii) racionalização da atividade administrativa e (iii) estabilização e uniformização de políticas públicas.

Considerando-se que em razão da impossibilidade de controle sem previsão normativa (pas de tutelle sans texte) a supervisão administrativa não pode ser presumida, a possibilidade de interposição de recurso hierárquico impróprio está obrigatoriamente vinculada a existência de expressa autorização normativa, ou seja, o controle administrativo desempenhado por meio do recurso hierárquico impróprio somente pode ser efetivado "nos termos e nos limites da norma que [o] houver estipulado" (FERRAZ; DALLARI, 2012, p. 282). É a existência de determinação normativa que define a competência recursal imprópria, de modo que somente por meio da aplicação do expressamente consignado em dispositivo normativo específico que se determinará o ente público e a respectiva autoridade administrativa competente para o processamento do recurso hierárquico impróprio (CARVALHO FILHO, 2013, p. 293) ${ }^{103}$.

Embora haja diversas peculiaridades que afastem o recurso hierárquico impróprio do recurso hierárquico próprio, é certo que ambos servem ao mesmo propósito: confirmar, modificar, anular ou revogar a decisão recorrida. Assim, tanto o recurso hierárquico próprio quanto o recurso hierárquico impróprio são mecanismos com a função de possibilitar a verificação e correição de ilegalidades ou inconveniências e inoportunidades ocorridas na prática do ato administrativo decisório. Em outros termos, a finalidade comum desses recursos administrativos é a satisfação dos interesses públicos e a efetivação dos princípios administrativos ${ }^{104}$.

\footnotetext{
${ }^{103}$ Nesse sentido, de maneira exemplificativa, "poderia uma lei específica determinar que o ato decisório proferido por uma autarquia devesse ser julgado por um órgão ministerial. Nesse caso, a decisão é conferida no âmbito da Administração Indireta, mas o recurso é encaminhado para um ente da Administração Direita" (MARRARA; NOHARA, p. 368).

${ }^{104}$ Note-se, contudo, que embora haja coincidência de finalidade, na prática, o recurso hierárquico próprio e o recurso hierárquico impróprio são manifestações distintas do controle administrativo. Essa diferença expressa-se por meio da necessidade de previsão normativa para proposição de recurso hierárquico impróprio, demonstrando sua especificidade em relação ao recurso hierárquico próprio - quase que com a replicação da relação norma geral-norma específica.
} 
Finalmente, é oportuno mencionar o Decreto-lei n. 200/67 naquilo que concerne aos recursos hierárquicos impróprios. Tendo em vista que, conforme o art. 19, "todo e qualquer órgão da Administração Federal, direta ou indireta, está sujeito à supervisão do Ministro de Estado competente, excetuados unicamente os órgãos mencionados no art. 32, que estão submetidos à supervisão direta do Presidente da República”, em regra, a competência para a decisão de recurso hierárquico impróprio é originalmente do ministro da pasta correspondente, sendo excepcionalmente atribuída ao Presidente da República naqueles casos em que se tratar de órgãos diretamente submetidos a supervisão do Chefe do Executivo.

\section{Elementos comuns dos recursos administrativos}

A existência de um núcleo compartilhado entre o recurso hierárquico próprio e o recurso hierárquico impróprio permite a identificação de elementos comuns às duas espécies de recursos administrativos.

Assim, serão apresentados a seguir tais elementos conforme previstos na Lei Federal n. 9.784/99.

\subsection{Gratuidade dos recursos administrativos: recolhimento de custas processuais e depósito recursal}

Conforme analisado anteriormente, os recursos administrativos constituem-se como um importante mecanismo de consolidação do direito de petição (art. $5^{\circ}$, XXXIV, $a \mathrm{CF} / 88$ ) no âmbito administrativo, pois asseguram aos cidadãos o direito de se manifestar por meio escrito à autoridade hierarquicamente superior ou ente público supervisor em defesa de direitos individuais e coletivos, contra ilegalidade ou abuso de poder cometidos pela autoridade decisória no momento da tomada de decisão. Além disso, os recursos administrativos também configuram-se como instrumento de controle administrativo, possibilitando à autoridade hierarquicamente superior ou ao ente público supervisor a verificação e correição dos atos administrativos decisórios, corrigindo ilegalidades ou atos inconvenientes e inoportunos.

Há, ainda, outra finalidade dos recursos administrativos, que se relaciona ao caráter político da via administrativa. Embora os entes públicos desfrutem de autonomia decisória quanto a sua gestão, o seu quadro de funcionamento, em decorrência de sua aderência à estrutura governamental, é externamente regulado (DUSSALT, 1992, p.13), 
isto é, a atividade administrativa está fundamentalmente associada ao poder político. Essa fixação dos objetivos dos entes públicos por uma autoridade externa os torna mais vulneráveis a interferências político-partidárias, afetando diretamente a gestão dessas organizações públicas e destacando condutas com vistas ao personalismo, patrimonialismo e clientelismo. Em outras palavras, os agentes públicos conduzem a prática administrativa com extrema fixação às regras e rotinas, supervalorização da estrutura hierárquica, paternalismo nas relações e profundo apego ao poder, de maneira a consolidar a debilidade de uma burocracia voltada ao estabelecimento de um "pequeno poder" da autoridade administrativa. Diante desse panorama, o recurso administrativo se estabelece como meio de proteção do cidadão contra o incremento político-partidário da atividade administrativa, possibilitando a interrupção de práticas voltadas ao personalismo, patrimonialismo e clientelismo.

Entretanto, a consolidação dessa vocação protetiva de direitos e garantias fundamentais inerente aos recursos administrativos faz necessária a existência de meios asseguradores e viabilizadores da apresentação dos recursos administrativos, dentre os quais destaca-se principalmente a gratuidade dos recursos administrativos.

O significado de gratuidade dos recursos administrativos relaciona-se com a impossibilidade de exigência de (i) pagamento de custas processuais e (ii) depósito em dinheiro ou arrolamento de bens (caução) para a admissibilidade dos recursos administrativos.

O custo da atividade administrativa é responsabilidade da Administração Pública e não pode ser diretamente repassado ao cidadão que está participando do processo administrativo (cidadão-parte) $)^{105}$, pois a função administrativa está integralmente comprometida com a satisfação do interesse público. A exigência de taxas ou o recolhimento de custas processuais para o prosseguimento do recurso administrativo é incompatível com a função administrativa, pois viola os princípios constitucionais orientadores da atividade do poder público - especialmente a supremacia do interesse público, finalidade, imparcialidade, isonomia, devido processo legal administrativo, contraditório e ampla defesa (art. $2^{\circ}$ da Lei Federal n. 9784/99 - e outros direitos fundamentais dos cidadãos como o direito de petição (art. $5^{\circ}$, XXXIV, $a$ CF/88). Portanto, é incompatível com os objetivos do processo administrativo a exigência do pagamento de custas processuais para prosseguimento do recurso administrativo, ou seja, é

${ }^{105}$ A função administrativa é indiretamente suportada por toda a coletividade, por meio da arrecadação de tributos. 
inconstitucional qualquer dispositivo normativo que subordine a interposição do recurso administrativo ao recolhimento de taxas ou pagamento de custas processuais.

O entendimento de que a exigência de depósito prévio pode significar a supressão do direito de petição (art. $5^{\circ}, \mathrm{XXXIV}, a \mathrm{CF} / 88$ ) e do devido processo legal administrativo (art. 5, LV CF/88) ao limitar o direito do cidadão de apresentar recurso contra decisão administrativa ocasionou o questionamento da constitucionalidade de diversos dispositivos normativos no Supremo Tribunal Federal ${ }^{106}$. Nesse sentido, destaca-se o precedente representativo da Súmula vinculante n. 21, que determinava que:

${ }^{106}$ Nesse sentido:

"O Plenário desta Suprema Corte, no julgamento conjunto da ADI 1922/DF, Rel. Min. Joaquim Barbosa, da ADI 1976, Rel. Min. Joaquim Barbosa, e do RE 390.513/SP, Rel. Min. Marco Aurélio, procedeu à revisão do entendimento jurisprudencial até então prevalecente na matéria ora em debate, firmando orientação no sentido de que se revela inconstitucional a exigência legal de efetivação do depósito como condição de admissibilidade de recursos em sede administrativa, notadamente quando se tratar de processo de caráter administrativo-fiscal. (...) Vê-se, portanto, que a diretriz consubstanciada na Súmula Vinculante $n^{\circ}$ 21/STF nada mais reflete senão a própria orientação que esta Corte Suprema firmou no sentido que a exigência de garantia fundada em depósito como condição de admissibilidade do recurso em sede administrativa culmina por afetar e comprometer, no âmbito desse procedimento, o exercício do direito de defesa." (SUPREMO TRIBUNAL FEDERAL, Reclamação n. 12.767, Decisão monocrática, Relator Ministro Celso de Mello, j. 19 dez 2011)

"A Súmula Vinculante 21 foi manifestamente afrontada pela decisão reclamada. Na votação da Proposta de Súmula Vinculante 21, a qual deu origem à referida súmula, o Min. Dias Toffoli assim se manifestou: '(...) Essa súmula mostra o caráter extremamente pedagógico, para o Estado brasileiro e para a administração pública, da utilidade da súmula vinculante contra a administração pública; grande relevo, pois alcança a defesa da cidadania e da Constituição, que busca garantir o exercício do recurso, independentemente da necessidade de depósito prévio'. O objetivo da Súmula Vinculante 21 é extinguir a exigência de depósito como requisito de admissibilidade de recursos administrativos. Nesse sentido, o Recurso Extraordinário 388.359, Rel. Min. Marco Aurélio, Tribunal Pleno, DJe 22.6.2007. A circunstância de o recurso ser interposto antes da edição do enunciado com força vinculante por este Tribunal não tem o condão de afastar a inconstitucionalidade da exigência de depósito prévio para interposição de apelos administrativos. Ademais, a decisão reclamada é a que foi proferida pelo Juiz de Direito da $2^{\mathrm{a}}$ Vara da Fazenda Pública da Comarca de Jaboatão dos Guararapes-PE contrariamente ao entendimento deste Supremo Tribunal Federal. Registro que referida decisão é posterior à edição da Súmula Vinculante 21. Ante o exposto, com base na jurisprudência pacífica da Corte, conheço da reclamação e julgo-a procedente (...)." (SUPREMO TRIBUNAL FEDERAL, Reclamação n. 10.938, Decisão monocrática, Relator Ministro Gilmar Mendes, j. 4 mar 2011)

"(...) concluiu a Corte que tanto a obrigação de arrolar os bens como a de depositar quantias para recorrer criavam o mesmo tipo de dificuldade, desarrazoada, para o contribuinte. Recentemente, o Supremo Tribunal Federal, analisando questão de ordem no AI 698.626 (...), reconheceu a existência de repercussão geral da matéria constitucional em debate - exigência de depósito prévio em recurso administrativo. Nesse mesma assentada, reafirmou-se o entendimento de que é inconstitucional a exigência de depósito prévio, como condição de admissibilidade de recurso administrativo em matéria tributária. (...) Ressalte-se que, em 29.10.2009, o Tribunal acolheu proposta de edição da Súmula Vinculante 21 (...)".(SUPREMO TRIBUNAL FEDERAL, Recurso Especial n. 46.882, Segunda turma, Relator Ministro Joaquim Barbosa, j. 6 abr 2010)

"O recurso inadmitido foi interposto contra o seguinte julgado do Tribunal de Justiça de São Paulo: 'Mandado de Segurança - Meio ambiente - Multa por infração ambiental - Sentença que não eximiu a empresa impetrante do recolhimento prévio do valor da multa imposta como condição para aceitação de seu recurso administrativo, o qual foi interposto contra decisão que manteve penalidade aplicada Admissibilidade - Recurso administrativo que não se confunde com primeira defesa - subsistência da sentença denegatória da ordem. Recurso ao qual se nega provimento' (fl. 42). (...) Examinados os elementos havidos no processo, DECIDO. 4. Razão jurídica assiste à Agravante. 5. No julgamento da Questão de Ordem no Agravo de Instrumento n. 698.626, Relatora a Ministra Ellen Gracie, o Plenário do Supremo 
[a] exigência de depósito ou arrolamento prévio de bens e direitos como condição de admissibilidade de recurso administrativo constitui obstáculo sério (e intransponível, para consideráveis parcelas da população) ao exercício do direito de petição $(\mathrm{CF}$, art. $\left.5^{\circ}, \mathrm{XXXIV}\right)$, além de caracterizar ofensa ao princípio do contraditório $\left(\mathrm{CF}\right.$, art. $5^{\circ}$, LV). A exigência de depósito ou arrolamento prévio de bens e direitos pode converterse, na prática, em determinadas situações, em supressão do direito de recorrer, constituindo-se, assim, em nítida violação ao princípio da proporcionalidade. (SUPREMO TRIBUNAL FEDERAL, Ação Direta de Inconstitucionalidade n. 1.976, Tribunal Pleno, Relator Ministro Joaquim Barbosa, j. 28 março de 2007)

A necessidade de se estabilizar o entendimento de que o depósito prévio pode constituir verdadeiro impedimento ao direito de petição e violação do devido processo legal administrativo impulsionou a edição da Súmula vinculante n. 21 do Supremo Tribunal Federal, que determinou a declaração da inconstitucionalidade da "exigência de depósito ou arrolamento prévios de dinheiro ou bens para admissibilidade de recurso administrativo".

\section{O alinhamento entre o Superior Tribunal de Justiça e o Supremo Tribunal Federal} quanto ao entendimento pela inexigibilidade de caução para o prosseguimento do recurso administrativo veio por meio da Súmula n. 373 do Superior Tribunal de Justiça, segundo a qual "é ilegítima a exigência de depósito prévio para admissibilidade de recurso administrativo". Entre os precedentes considerados para a edição dessa súmula, foram citados vários recursos especiais, dentre os quais destaca-se o Recurso Especial $\mathrm{n}$. 953.664, que estabeleceu que "a exigência de depósito prévio de 30\% do valor da

Tribunal Federal reconheceu a existência de repercussão geral do tema e reafirmou a jurisprudência no sentido de ser inconstitucional a exigência de depósito prévio como requisito de admissibilidade de recurso administrativo: (...)" (SUPREMO TRIBUNAL FEDERAL, AI n. 751.890, Decisão monocrática, Relatora Ministra Cármen Lúcia, j. 31 maio 2012)

"Ementa: Arguição de Descumprimento de Preceito Fundamental. § 1o do art. 636 da Consolidação das Leis do Trabalho: não recepção pela Constituição de 1988. 1. Incompatibilidade da exigência de depósito prévio do valor correspondente à multa como condição de admissibilidade de recurso administrativo interposto junto à autoridade trabalhista ( $\$ 1$ o do art. 636, da Consolidação das Leis do Trabalho) com a Constituição de 1988. Inobservância das garantias constitucionais do devido processo legal e da ampla defesa (art. $5^{\circ}$, incs. LIV e LV); do princípio da isonomia (art. $5^{\circ}$, caput); do direito de petição (art. $5^{\circ}$, inc. XXXIV, alínea a). Precedentes do Plenário do Supremo Tribunal Federal: Recursos Extraordinários 389.383/SP, 388.359/PE, 390.513/SP e Ação Direta de Inconstitucionalidade 1.976/DF. Súmula Vinculante $n^{\circ}$ 21. 2. Ação julgada procedente para declarar a não recepção do $\S 10$ do art. 636 da Consolidação das Leis do Trabalho pela Constituição da República de 1988."(SUPREMO TRIBUNAL FEDERAL, Arguição de descumprimento de preceito fundamental n.156, Tribunal pleno, Relatora Ministra Carmen Lúcia, j. 18 ago 2011)

"Bem examinados os autos, constato que esta reclamação é manifestamente incabível, o que impõe a imediata extinção do feito. Com efeito, a reclamante alega que foi violada a Súmula Vinculante 21 (...). Como se observa, a referida súmula refere-se, expressamente, à impossibilidade de exigência de depósito prévio para a admissibilidade de recurso administrativo, entendimento que não é extensível, como pretende à reclamante, aos processos judiciais. Além disso, não cabe analogia na interpretação dos verbetes de súmulas vinculantes. Assim, diante da ausência de identidade material entre os fundamentos do ato reclamado e aqueles emanados da súmula vinculante ora invocada, não merece seguimento a pretensão da reclamante." (SUPREMO TRIBUNAL FEDERAL, Reclamação n. 11.750, Decisão monocrática, Relator Ministro Ricardo Lewandowski, j. 11 abr 2012) 
exigência fiscal, como condição de admissibilidade do recurso administrativo, é ilegítima, em face da inarredável garantia constitucional da ampla defesa" (SUPERIOR TRIBUNAL DE JUSTIÇA, Recurso Especial n. 388.359/PE, Tribunal Pleno, Relator Ministro Marco Aurélio, j. 28 mar 2007).

O art. 56, §2 da Lei Federal n. 9.784/99 consolidou a intepretação constitucional e o entendimento jurisprudencial de que a interposição de recurso administrativo independe de caução, exceto naqueles casos expressamente previstos. Assim, também ficou estabelecido infraconstitucionalmente a gratuidade dos recursos administrativos como forma de concretizar o direito ao recurso (MARRARA; NOHARA, 2009, p.371).

Por fim, é interessante apenas destacar que o recolhimento de custas processuais e o depósito prévio não podem ser estabelecidos como meio para prevenção de litigância protelatória - diferentemente da determinação consignada no art. 511 do Código de Processo Penal e no art. 899 da Consolidação das Leis do Trabalho - nem ser instrumento de percepção de créditos fazendários (DALLARI; FERRAZ, 2012, p.280).

\subsection{Legitimidade e competência recursal}

Conforme explicado anteriormente, a apresentação do recurso administrativo não instaura uma nova relação jurídica, ao contrário, o recurso administrativo constitui uma extensão do processo administrativo e um prolongamento da relação jurídica original. Há, nesse sentido, certa simetria entre as condições da ação ${ }^{107}$ e os requisitos de admissibilidade dos recursos ${ }^{108}$ (NERY JUNIOR, 2004, p.274), de modo a ser possível a identificação de correspondentes específicos em cada um desses âmbitos (JORGE, 2007, p.81).

A legitimidade (ativa e passiva) se refere à titularidade da situação jurídica conflituosa (SILVA, 2006, p.91), ou seja, terá legitimidade aquele sujeito processual que possuir qualidade para agir (SANTOS, 1995, p.167). Há duas espécies de legitimidade conforme o momento em que se encontra a relação processual: (i) a legitimidade $a d$ causam e (ii) a legitimidade recursal. Assim, enquanto a legitimidade ad causam é a condição subjetiva para apresentar o requerimento para instauração do processo

\footnotetext{
107 Segundo a teoria processual, as condições da ação são todos os requisitos cujo preenchimento é necessário tanto para o exercício legítimo do direito de ação quanto para a existência da própria ação (CINTRA; GRINOVER; DINAMARCO, 2007, p. 274).

108 De acordo com NERY JUNIOR, os requisitos de admissibilidade são o objeto do juízo de admissibilidade, ou seja, "qual a matéria que deve ser decidida na fase de admissibilidade do recurso, a fim de que se lhe possa julgar o mérito, dando-lhe ou negando-lhe provimento" (2004, p.273)
} 
administrativo, a legitimidade recursal refere-se ao requisito subjetivo para que se possa exercer o direito de recorrer da decisão administrativa ${ }^{109}$.

Tendo em vista novamente que o recurso administrativo configura uma extensão da relação jurídica processual, é possível compreender que a lista de sujeitos legitimados para a apresentação do requerimento deve conter a lista de sujeitos legitimados para recorrer da decisão administrativa ${ }^{110}$. Observe-se o diagrama abaixo referente a legitimidade na Lei Federal n. 9.784/99:

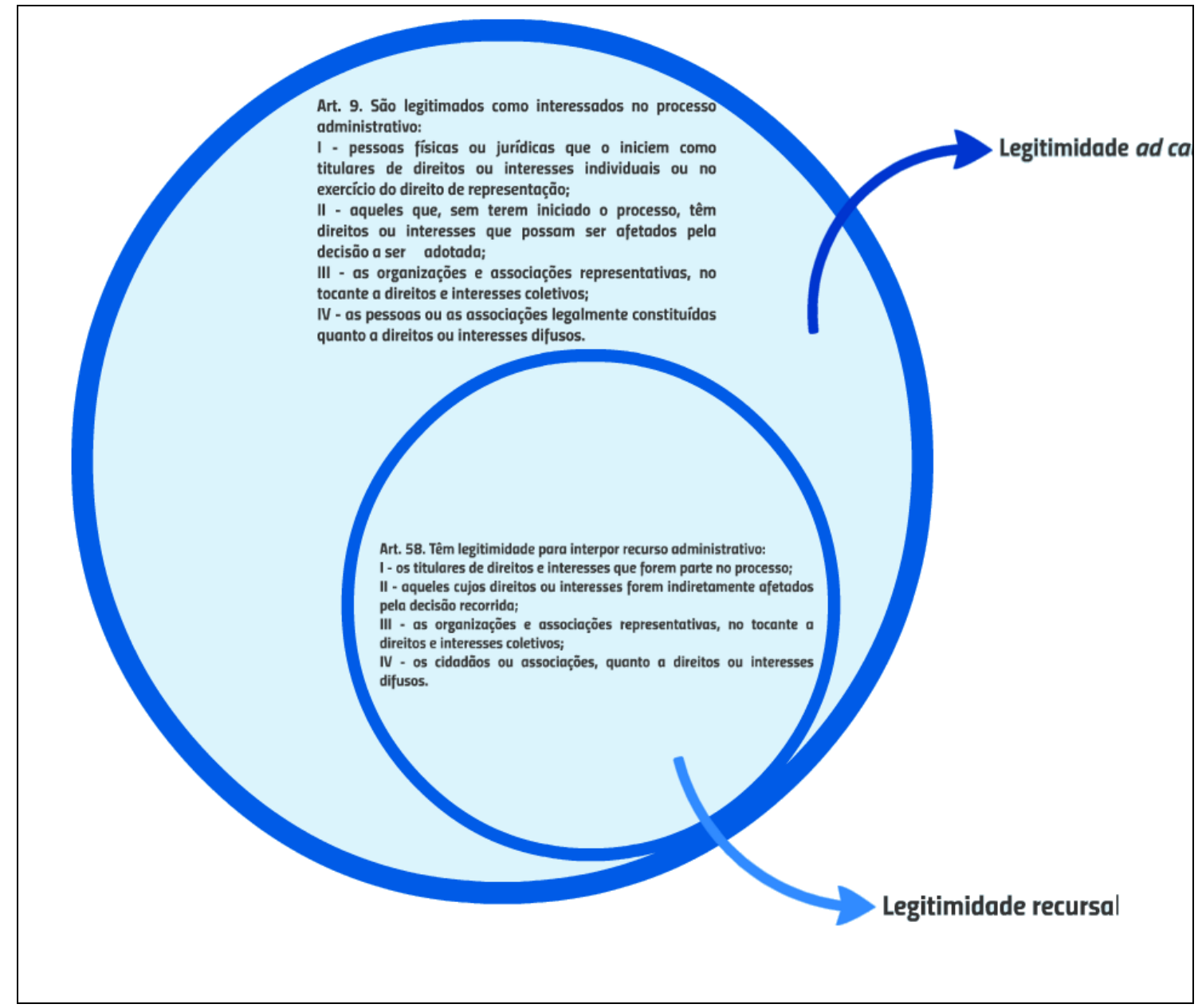

Figura 03: Diagrama da legitimidade no processo administrativo Fonte: elaborada própria a partir da Lei Federal n. 9.784/99

${ }^{109}$ Nesse sentido, "[a]ssim como a legitimação para agir é condição do exercício regular do direito de ação, e portanto da possibilidade de julgar-se o mérito da causa, analogamente a legitimação para recorrer é requisito de admissibilidade do recurso, que precisa estar satisfeito para que o órgão ad quem dele conheça, isto é, o julgue no mérito" (MOREIRA, J. C. B, 1993, p. 287).

${ }^{110}$ Excepciona-se essa regra de contingência nas situações em que o mérito do recurso administrativo for evidentemente a questão da legitimidade, isto é, não se pode deixar de conhecer o recurso por ausência de legitimidade recursal nos casos em que a legitimidade ad causam for o objeto do questionamento (NERY JUNIOR, 2004, p.274) 
Por meio da comparação dos dois róis expressos nos dispositivos normativos, é possível verificar que a lei tratou de limitar, por razões de conveniência, os sujeitos legitimados para a apresentação do recurso administrativo, pois "[c]aso atribuísse a qualquer um o poder de utilizar-se dos recursos, o sistema seria praticamente inviável e inoperante" (JORGE, 2007, p.82). Na realidade, a regra de atribuição da legitimidade recursal parte do pressuposto de que as pessoas diretamente ou indiretamente afetadas pelos efeitos da decisão administrativa serão justamente aquelas com o interesse na impugnação dessa decisão (MOREIRA, J. C. B., 1968, p. 52). Note-se, contudo, que esse interesse é atribuído genericamente ao sujeito pela norma jurídica, não sendo, pois, condicionante da legitimidade, haja visto ser possível na prática que o sujeito possua a legitimidade para a interposição do recurso, mas não deseje efetivamente apresentá-lo (JORGE, 2007, p.82).

A referência para as regras de legitimidade no processo administrativo federal está contida em dois dispositivos distintos da Lei Federal n. 9.784/99, sendo o primeiro relacionado à legitimidade para apresentação do requerimento para instauração do processo administrativo (art. $9^{\circ}$ ) e o segundo relativo à legitimidade recursal (art. 58). Com efeito, conforme BUENO, o art. 58 "é, embora não literalmente, o transporte, para a fase recursal do rol dos 'legitimados como interessados no processo administrativo' de que trata o art. 9"” (2006, p.196).

$\mathrm{O}$ art. 58 da Lei Federal n. 9.784/99 apresenta quatro hipóteses de legitimidade recursal, dispostas em incisos específicos.

$\mathrm{O}$ inciso I estabelece legitimidade aos titulares de direitos e interesses originalmente integrantes da relação processual administrativa, ou seja, trata-se da hipótese mais óbvia, pois contempla o sujeito processual que entendeu ter tido desamparada sua pretensão pela decisão adotada. Contudo, o conteúdo mais importante apresentado pela regra do inciso consiste na diferenciação expressa entre "direitos" e "interesses", que tem o mérito de assinalar "que nem sempre é possível subjetivar um interesse (ou afirmação de direito) em alguém determinado: ou porque um mesmo interesse pertence a mais de um indivíduo ao mesmo tempo ou porque pertence a todos indistintamente e ao mesmo tempo" (BUENO, 2006, p.197), pois possibilita uma ampliação dos bens juridicamente protegidos. Ainda a respeito desse inciso, na situação em que houver pluralidade de sujeitos, aplica-se a regra disposta no art. $8^{\circ}$ da mesma lei, que determina que caso os pedidos tenham o conteúdo e fundamentos idênticos, poderão ser formulados em um único requerimento, o que torna o processo mais eficiente e célere, 
lembrando somente que, nos casos em que houver pluralidade de sujeitos e somente uma parcela deles (ou apenas um dos sujeitos) apresentar recurso administrativo, conforme a redação do art. 62, a autoridade que receber esse recurso deverá intimar os demais sujeitos para manifestação no prazo de cinco dias corridos, momento em que esses poderão oporse ao conteúdo do recurso.

Por sua vez, o inciso II habilita a participação de terceiros cujos direitos ou interesses tenham sido reflexamente afetados pela decisão adotada, ou seja, considera legitimados aqueles que, em decorrência de ônus ou gravame suportado em razão do teor decisório, são indiretamente interessados na modificação da decisão (CARVALHO, 2013, p. 304). Há duas anotações a serem feitas: (i) o interesse tutelado por essa regra é exclusivamente o interesse jurídico, ainda que esse interesse possa também apresentar concomitantemente natureza diversa (econômica, social, pessoal, etc.) ${ }^{111}$; (ii) o terceiro interessado pode ser pessoa física ou jurídica nacional ou estrangeira, vez que o ordenamento jurídico não veda essa possibilidade. Em suma, a legitimação dos terceiros depende somente da comprovação da existência de violação a direito ou interesse juridicamente tutelado, mesmo que esse terceiro não tenha participado originalmente do processo administrativo (MARRARA; NOHARA, 2009, p. 379).

$\mathrm{O}$ inciso III trata da legitimidade das organizações e associações representativas de direitos e interesses coletivos ${ }^{112}$. Segundo explica CARVALHO FILHO, quando a decisão administrativa violar direitos e interesses de uma coletividade determinável, então os representantes legitimamente constituídos terão "idoneidade para defender os interesses de seus representados no processo administrativo" (2013, p. 305), desde que atendidos três requisitos: (i) a questão debatida no processo administrativo relacione-se a direitos coletivos - constitucionalmente ou infraconstitucionalmente previstos - de uma pluralidade de sujeitos determinável; (ii) a questão tratada enquadre-se dentre as competências da autoridade administrativa; e (iii) o recurso administrativo constitua o meio mais hábil para a proteção desses direitos coletivamente considerados.

\footnotetext{
${ }^{111}$ Nesse sentido, "não interessa se o interesse é econômico social ou de qualquer outro gênero [, pois, ao] aceitar recurso daquele que alega interesse no objeto do processo administrativo, à autoridade não compete questionar se ele é econômico, social etc. Ela deve tão somente verificar se o interesse, a despeito de seu conteúdo, está juridicamente protegido. Essa sim é a questão-chave" (MARRARA; NOHARA, 2009, p. 378).

112 "Direitos coletivos, como já foi visto, são aqueles transindividuais, de natureza indivisível, pertencentes a grupos de pessoas ligadas entre si por uma relação jurídica base” (CARVALHO FILHO, 2013, p.305).
} 
Finalmente, o inciso IV atribui legitimidade recursal aos cidadãos ou associações em relação a decisões em que figurem direitos ou interesses difusos ${ }^{113}$. Na hipótese considerada pelo inciso, os cidadãos não são qualificados enquanto titulares de direitos individualmente considerados, mas legitimam-se como representantes de direito titularizado indistintamente por toda a coletividade (BUENO, 2006, p. 199).

Definida a questão da legitimidade recursal, direciona-se a análise ao exame da competência recursal.

Requisito essencial do ato administrativo, a competência é "o conjunto de atribuições das pessoas jurídicas, órgãos e agentes, fixadas pelo direito positivo" (DI PIETRO, 2011, p.205), ou seja, trata-se do poder-dever atribuído pelo ordenamento jurídico à autoridade administrativa para o desempenho da função administrativa (MEIRELLES, 2002, p.147). Assim, a competência recursal é o poder-dever que a lei conferiu a determinado agente público para o desempenho do juízo recursal, que, na prática, significa o recebimento e o processamento do recurso administrativo com a emissão de novo ato administrativo decisório.

Embora frequentemente empregados, os termos direcionamento e endereçamento do recurso administrativo podem causar certa confusão quanto à determinação da autoridade administrativa competente para a apreciação do recurso administrativo, motivo pelo qual, é preferível se utilizar somente o vocábulo competência para designar o agente público a quem foi atribuído o poder-dever de decisão do recurso administrativo.

Conforme explicado anteriormente, a regra de competência deve ser expressamente determinada por norma jurídica específica, ainda que de maneira genérica. $\mathrm{Na}$ realidade, seria praticamente inviável que a lei estabelecesse especificamente a autoridade administrativa competente para a apreciação do recurso, vez que a Administração Pública - direta e indireta - é composta por uma grande diversidade de entes, órgãos e agentes públicos, motivo pelo qual, a determinação da autoridade administrativa competente dependerá do organograma do ente público em que tramita o processo administrativo (BUENO, 2006, p.194) ${ }^{114}$.

\footnotetext{
113 "Direitos difusos também são transindividuais, de natureza indivisível, mas os componentes do grupo são vinculados de forma contingencial ou por mero acaso, inexistindo aquela relação jurídica base que marca os direitos coletivos" (CARVALHO FILHO, 2013, p.305).

114 "Embora a Lei federal não indique quem é a autoridade competente para julgamento do recurso - o que dependerá, destarte, de outras disposições normativas e de hipóteses concretas -, limita as 'instâncias administrativas' a três, ressalvada previsão legal em sentido contrário (art.57)” (BUENO, 2006, p.194).
} 
No âmbito do processo administrativo federal, a regra de competência para a apreciação dos recursos administrativos está estipulada no art. $56, \S^{\circ}$ da Lei Federal n. 9.784/99, conforme a seguinte redação: “o recurso será dirigido à autoridade que proferiu a decisão, a qual, se não a reconsiderar no prazo de cinco dias, o encaminhará à autoridade superior".

Segundo o critério desse dispositivo normativo, o recurso administrativo deverá ser protocolado diretamente no âmbito do órgão responsável pela decisão administrativa, para que a autoridade decisória realize o juízo de admissibilidade desse recurso e o juízo de reconsideração do pedido de reconsideração. Trata-se de atividade vinculada, pois à autoridade administrativa não caberá ponderação acerca da conveniência e oportunidade (CARVALHO FILHO, 2013, p.298) do pedido, mas somente a análise do cabimento, legitimidade e competência recursais, não podendo, pois, impedir o prosseguimento do recurso administrativo senão por vício de forma ou em virtude da reconsideração da decisão. Concluídos os juízos de admissibilidade e de reconsideração, a autoridade decisória encaminhará o recurso administrativo para a autoridade superior ${ }^{115}$, que realizará o recebimento e processamento desse recurso e emitirá um novo ato administrativo decisório ${ }^{116}$.

Note-se que o art. $56, \S^{\circ}$ não estabeleceu diferenciação entre a competência recursal para a apreciação do recurso hierárquico próprio e a competência recursal para análise do recurso hierárquico impróprio. Não haveria, porém, necessidade do legislador ter efetivamente estabelecido de maneira individualizada a competência recursal para cada uma dessas espécies, pois o recurso administrativo somente será dirigido a uma

\footnotetext{
115 Ao encaminhar o recurso administrativo à autoridade superior competente, não há obrigatoriedade da autoridade administrativa motivar a manutenção de sua decisão, salvo nos casos em que o recurso administrativo apresentado tratar da hipótese prevista no art. 56, $\S 3^{\circ}$ e no art. 64-A da Lei Federal n. 9.784/99, ou seja, nas situações em que o recurso administrativo fundamentar-se em ofensa a súmula vinculante. Nessa situação, a autoridade administrativa deverá encaminhar, juntamente com o recurso administrativo, os motivos pelos quais acredita que sua decisão não viola a sumula vinculante em questão (DALLARI, FERRAZ, 2012, p. 297).

116 "Cabe lembrar que, nos termos do $\S 1^{\circ}$ do art.56, o recurso é encaminhado à autoridade recorrida, que pode reconsiderar sua decisão ou, então, deve, por sua vez, encaminhá-lo à decisão da autoridade superior competente. Ontologicamente, a competência para decidir recurso administrativo hierárquico é da autoridade hierarquicamente superior; a autoridade recorrida, nos termos da lei federal de processo administrativo, apenas pode reconsiderar sua decisão ou encaminhar o recurso voluntário ao exame da autoridade superior, não se configurando, absolutamente, nesse simples encaminhamento a existência de recurso de ofício" (DALLARI; FERRAZ, 2012, p. 296)
} 
autoridade que não é hierarquicamente superior à autoridade recorrida por expressa determinação normativa (DALLARI; FERRAZ, 2012, p.281) $)^{117}$

$\mathrm{Na}$ hipótese em que acontecer o direcionamento incorreto do recurso administrativo, a autoridade administrativa que realizou o recebimento desse recurso poderá optar por duas soluções possíveis: (i) redirecionar o recurso para a autoridade competente; ou (ii) informar ao interessado sobre a incompetência, possibilitando-lhe nova oportunidade de direcionamento à autoridade competente. Destaque-se que, se "o recurso não foi interposto no prazo determinado em razão da orientação errônea, incompleta ou falha da autoridade administrativa, deverá, então, o prazo recursal ser devolvido" (MARRARA; NOHARA, 2009, p. 388) ${ }^{118}$.

\subsection{Prazos}

Quando se examina a questão dos prazos recursais, deve-se ter em consideração a existência de diversos tipos diferentes de prazos, pois cada procedimento do processo administrativo deverá ser desenvolvido dentre de um determinado período normativamente estipulado. Nesse sentido, observe-se a tabela a seguir:

\begin{tabular}{|c|c|}
\hline Tipo de prazo & Prazo \\
\hline Interposição & $10(\mathrm{dez})$ dias corridos \\
\hline Reconsideração & 05 (cinco) dias corridos \\
\hline Manifestação de outros interessados & 05 (cinco) dias corridos \\
\hline Decisão recursal & 30 (trinta) dias corridos prorrogáveis por \\
igual período
\end{tabular}

Tabela 05: Prazos recursais na Lei Federal n. 9.784/99

Fonte: elaboração própria a partir da Lei Federal n. 9.784/99

As regras de contagem de prazo estão previstas no art. 66 da Lei Federal n. 9.784/99, segundo os seguintes critérios: (i) os prazos iniciam-se na data da cientificação

\footnotetext{
117 "A tutela somente pode ser exercitada nos termos e nos limites da norma que a houver estipulado (que pode prever ou não a possibilidade de recurso hierárquico impróprio), pois não se confunde com o controle hierárquico" (DALLARI; FERRAZ, 2012, p. 282)

118 "O art. 63, $\$ 1^{\circ}$, da Lei n. 9.784/99 traduz esse princípio [do formalismo moderado] ao dispor que a interposição do recurso em face de órgão incompetente não impede o seu conhecimento, devendo ser indicada ao recorrente a autoridade competente, sendo-lhe devolvido o prazo para recurso" (BACELLAR FILHO, 2013, p. 191)
} 
oficial $^{119}$, excluindo-se da contagem o primeiro dia e incluindo-se o dia do vencimento do prazo (art. 66, caput); (ii) ocorrerá prorrogação do prazo até o primeiro dia útil seguinte, se no dia de vencimento do prazo não houver expediente ou se o expediente do ente público encerrar-se antes do horário normal (art. 66, §1º); (iii) os prazos expressos em dias deverão ser considerados "corridos", ou seja, serão contados de modo contínuo (art. 66, $\S 2^{\circ}$ ); e (iv) os prazos fixados em meses ou anos deverão ser contados de data a data, de modo que, se no mês do vencimento não houver equivalente à data do mês inicial, o último dia do mês deve ser adotado como termo $\left(\operatorname{art} .66, \S 3^{\circ}\right)^{120}$.

O art. 59 da Lei Federal n. 9.784/99 estabelece que o prazo geral para apresentação de recurso administrativo para a autoridade superior competente é de 10 (dez) dias corridos, admitindo-se, porém, que lei específica estipule prazo diverso. Na realidade, a legislação específica que pretenda estabelecer prazo distinto daquele determinado pela Lei Federal n. 9.784/99 deve orientar-se não pelo ganho de eficiência e celeridade, mas pela ampliação dos direitos e garantias fundamentais, permitindo a efetivação do devido processo legal administrativo por meio do alargamento das condições de realização do contraditório e da ampla defesa, em outras palavras, não deve diminuir o número de dias corridos para interposição do recurso, a não ser que essa hipótese venha a ampliar as condições de realização de direitos e garantias fundamentais dos envolvidos, pois os cidadãos “em geral, que podem atuar sem advogados no processo administrativo, não têm conhecimento dessas situações de natureza técnica, e esse fato pode levar a confusões indesejadas" (CARVALHO FILHO, 2013, pp. 305-306) ${ }^{121}$.

\footnotetext{
${ }^{119}$ Quanto a cientificação, "a intimação oficial deve ser segura, valendo aquela publicada no diário oficial do órgão competente, ou se realizada de modo pessoal. Certo é que deve constar de modo expresso a cientificação dos atos do processo aos interessados" (FORTINI; PEREIRA; CAMARÃO, 2012, p. 218). Contudo, no caso de interessado determinado, há assentado entendimento de que "Nos termos do art. 26, § 3o. c/c o art. 29 da Lei 9.784/99, tratando-se de interessado determinado, conhecido ou que tenha domicílio definido, como no caso dos autos, a intimação dos atos administrativos dar-se-á por ciência no processo, por via postal com aviso de recebimento, por telegrama ou por qualquer outro meio que assegure a certeza da ciência do interessado" (SUPERIOR TRIBUNAL DE JUSTIÇA. Mandado de Segurança n. MS 15912 DF 2010/0207756-0, Relator: Ministro Napoleão Nunes Maia Filho, j. em 09 nov 2011. Disponível em $<$ www.stj.gov.br>. Acesso em 07 fev 2015.)

120 “O prazo para recurso é peremptório e contínuo. Peremptório, porque nem a Administração nem os interessados podem alterá-lo; contínuo, porque não se suspende ou interrompe em razão de feriados, domingos e dias sem expediente, conforme averba o art. 67, salvo mediante comprovação da existência de força maior" (CARVALHO FILHO, 2013, p.306)

121 "Uma alteração do prazo de interposição de recurso exige previsão especial em norma contida em lei. Mesmo nesse caso, ou seja, na hipótese de se fixar prazo especial em outra lei, deverá o Legislador respeitar o princípio da razoabilidade. Desse modo, se desejar reduzir o prazo de recurso, deverá fazê-lo apenas até o limite em que a ampla defesa do interessado não seja impossibilitada. A redução do prazo que tornar impossível o exercício dos direitos recursais e, por consequência, restringir desproporcionalmente a defesa dos interessados, será inconstitucional” (MARRARA; NOHARA, 2009, p.384)
} 
O recurso administrativo apresentado fora do prazo deverá ser considerado intempestivo, de maneira que não será conhecido pela autoridade administrativa competente e tampouco produzirá efeitos jurídicos (art. 63, inciso I Lei Federal n. 9.784/99), a não ser na hipótese em que, por orientação errônea da própria autoridade administrativa, o cidadão seja levado a apresentar o recurso administrativo fora do prazo estabelecido. Comprovado o erro do agente público, o recurso administrativo deverá ser recebido e processado regularmente.

Ainda no sentido de ampliação dos direitos e garantias fundamentais dos envolvidos no processo administrativo, deve-se destacar a situação em que houver pluralidade de interessados em qualquer dos polos e apenas um ou parte desses interessados apresentar recurso administrativo. Nessa hipótese, a autoridade administrativa obrigatoriamente deverá conceder aos demais interessados prazo de até cinco dias corridos para que se manifestem quanto ao conteúdo do recurso interposto (VELOSO, 2012, p. 180).

A decisão também demanda prazo. Primeiramente, há o prazo para reconsideração, ou seja, antes do encaminhamento do recurso administrativo para a autoridade superior competente, deverá a autoridade decisória proceder ao juízo de reconsideração - reconsiderando ou não sua própria decisão - no prazo máximo de cinco dias corridos (art. 56, §1 ${ }^{\circ}$ Lei Federal n. 9.784/99). Não havendo reconsideração da decisão, recebido o recurso administrativo, a autoridade superior competente disporá de trinta dias corridos (art. 59, $\S 1^{\circ}$ Lei Federal n. 9.784/99) prorrogáveis por igual período, isto é, mais trinta dias corridos, desde que devidamente comprovada e motivada a necessidade de prorrogação (art. 59, §2º Lei Federal n. 9.784/99) ${ }^{122}$.

O prazo estipulado para que a autoridade superior competente decida sobre o recurso administrativo apresentado obrigatoriamente vincula sua atuação, ou seja, o agente público que, sem motivação razoável, omitir-se do dever funcional de decisão dentro do prazo legal deverá ser administrativa e judicialmente responsabilizado pela conduta funcional ilícita, pois essa omissão constitui abuso de poder ou renúncia de competência passível de controle administrativo (CARVALHO FILHO, 2013, p.307). Entretanto, embora a redação do art. $59\left(\S \S 1^{\circ}\right.$ e $\left.2^{\circ}\right)$ seja bastante inequívoca quanto ao prazo concedido ao agente público para manifestar-se em caráter decisório sobre o

\footnotetext{
122 Compreende-se que a expressão "por igual período" não permite fracionamento do período de prorrogação, caso fosse essa a intenção do legislador, o dispositivo normativo deveria apresentar a expressão "por até igual período".
} 
conteúdo do recurso administrativo, o que se verifica na rotina dos entes públicos administrativos é a arbitrariedade quanto ao cumprimento dos prazos estabelecidos, sendo frequentemente adotado o prazo de sessenta dias para decisão, sem a apresentação de qualquer motivação que justifique essa opção. O grande problema é que, no mais das vezes, o poder judiciário avaliza essa conduta ou por desconhecimento da estrutura organizacional interna dos entes públicos ou pelo temor de incorrer em violação da separação de poderes, nesse sentido, muitas decisões acabam adotando teor similar ao que se transcreve a título exemplificativo:

O cumprimento de prazos para apreciação de recursos administrativos pela Administração Pública, segundo os ditames dos artigos 49,59, § $1^{\circ}$, e 69 da Lei $n^{\circ}$ $9784 / 99$, deve ser sopesado com as condições inerentes aos órgãos da administração pública, da peculiaridade do processo, bem como a análise, dentro da razoabilidade, do tempo decorrido sem qualquer prática do ato. (SUPERIOR TRIBUNAL DE JUSTIÇA. Agravo Regimental no Mandado de Segurança n. 18555 DF 2012/0104819-0, Relator: Ministro Mauro Campbell Marques, j. 27 fev 2013. Disponível em <www.stj.gov.br>. Acesso em 07 fev 2015)

Eventualmente, a legislação específica pode alterar o prazo de prorrogação ou, inclusive, impossibilitar a vedação do prazo. Contudo, a norma jurídica que venha a determinar o impedimento de solicitação de prorrogação de prazo pela autoridade administrativa deve, expressamente, indicar os efeitos decorrentes do silêncio administrativo, isto é, se a omissão do agente público significar o deferimento ou indeferimento tácito do pedido apresentado no recurso administrativo (MARRARA; NOHARA, 2009, p. 387).

\subsection{Decisão em sede recursal}

Conforme explicado anteriormente, constitui obrigação da Administração Pública formalizar em texto escrito sua posição ou decisão quanto a postulação que lhe foi feita pelo cidadão - considerado como cidadão a pessoa física ou jurídica - por meio escrito, ou seja, a autoridade administrativa competente possui o poder-dever de apreciar e expressamente decidir por escrito, de maneira clara e compreensível, aquilo quanto lhe foi apresentado por meio de petição inicial ou recursal, ainda que seja para decidir pelo indeferimento desse pedido. Além dessa obrigação fundamentar-se no direito de petição (art. 5. ${ }^{\circ}$, XXXIV, "a" da CF/88), o art. 48 da Lei Federal n.9.784/99 estabelece que a Administração Pública "tem o dever de explicitamente emitir decisão nos processos administrativos e sobre solicitações ou reclamações, em matéria de sua competência". 
Considerando-se o recurso administrativo como uma extensão da relação processual administrativa, é correto afirmar que esse dever de apreciação (dever de decidir) não está limitado ao processo administrativo, obrigando, portanto, a autoridade administrativa a emitir decisão quanto ao recurso administrativo regularmente apresentado (VELOSO, 2012, p.187).

No âmbito recursal administrativo, a decisão compreende a possibilidade de (i) confirmar, (ii) modificar, (iii) anular ou (iv) revogar o ato decisório impugnado, nos limites da competência da autoridade administrativa. Há, contudo, que se destacar a existência de dois critérios limitadores da decisão em sede recursal: a discricionariedade e a vinculação. Enquanto que a decisão por critério discricionário permite ao agente público a adoção de solução alternativa fundamentada por elementos de conveniência e oportunidade, a decisão por critério vinculado obriga a autoridade administrativa a se manifestar exclusivamente quanto ao cumprimento dos requisitos obrigatórios para a prática do ato administrativo decisório (MARRARA; NOHARA, 2009, p. 405) ${ }^{123}$.

A questão mais importante quanto à decisão recursal, entretanto, não é de caráter classificatório, mas concerne a obrigatoriedade da autoridade administrativa competente desempenhar o processo decisório em sede recursal de maneira a não violar, em hipótese alguma, os direitos e garantias fundamentais dos interessados nessa decisão ${ }^{124}$. Assim, é imprescindível que haja respeito ao devido processo legal administrativo, garantindo-se aos cidadãos o exercício do contraditório e da ampla defesa, considerando-se todas as alegações e documentos apresentados tanto em sede recursal, quanto ao longo do processo administrativo para fins de apreciação do pedido, bem como a produção de uma decisão criteriosamente motivada, balizada por critérios de razoabilidade e proporcionalidade, buscando sempre o atendimento do interesse público na sua forma mais ampliativa de direitos difusos e coletivos ${ }^{125}$.

\footnotetext{
123 “Com efeito, se o ato impugnado é inválido, sua modificação, reforma ou revogação em resposta ao recurso é o comportamento esperado da Administração. Por outro lado, se o ato é válido e a impugnação se funda em razões de mérito, as faculdades da Administração ao decidir o recurso dependem do grau de estabilidade que tenha adquirido a situação criada pelo ato: se essa situação pode ser modificada discricionariamente pela Administração, do mesmo modo poderá decidir o recurso. Por outro lado, se o ato criou uma situação jurídica dotada de estabilidade de modo que a Administração não possa modifica-la discricionariamente, o recurso retira as restrições à mutabilidade do ato, mas somente nos termos da pretensão do recorrente" (DELPIAZZO, 2006, p.255)

124 "Não há, portanto, problema algum na adoção de novo entendimento pela autoridade superior, mas cabe lembrar que o recurso administrativo também está adstrito aos princípios do contraditório e da ampla defesa. $\mathrm{Na}$ verdade, aplicam-se à decisão proferida em segunda instância todos os princípios, preceitos, requisitos e cuidados" (DALLARI; FERRAZ, 2012, p. 301)

125 "Esse poder, repita-se, bastante amplo deferido à Administração na reavaliação dos recursos administrativos, carece ser mais bem utilizado pelas autoridades competentes. Isso porque, em grande parte
} 


\subsubsection{Confirmação}

A confirmação é uma espécie de decisão recursal em que a autoridade superior competente (ad quem) para a apreciação do recurso administrativo mantém a decisão originalmente proferida pela autoridade administrativa (a quo), corroborando completamente com a solução inicialmente adotada, ou seja, nessa hipótese, o agente público estará negando provimento ao recurso administrativo pelo indeferimento de seu pedido. Dessa forma, não é possível se falar em confirmação parcial, pois quaisquer mudanças, ainda que parciais, ao teor decisório originalmente adotado ensejará uma decisão recursal modificadora, descaracterizando-se a confirmação (CARVALHO FILHO, 2013, p. 322).

Embora a confirmação signifique a manutenção da decisão original ( $a$ quo), não há obrigatoriedade na adoção inalterada dos fundamentos fáticos ou jurídicos na motivação decisão recursal (ad quem), podendo, portanto, verificar-se situação em que a autoridade superior venha a alcançar idêntica solução baseada em fundamentos fáticos ou jurídicos inteiramente distintos ou, até mesmo, divergentes daqueles adotados na motivação da decisão original ${ }^{126}$. Contudo, ainda que na hipótese de manutenção da motivação originalmente adotada a decisão recursal possa apenas ser expressa por meio de uma declaração de concordância, nos casos em que houver a identificação de fundamentos fáticos ou jurídicos diferentes daqueles apresentados na decisão original, o agente público deverá esclarecer adequadamente cada um desses novos fundamentos, por meio da elaboração de uma criteriosa motivação para sua decisão recursal (MAHARA; NOHARA, 2009, p. 406) ${ }^{127}$.

\subsubsection{Modificação}

\footnotetext{
das vezes, a apreciação dos recursos se limita a seus aspectos mais formais, com mera repetição das razões de decidir da instância inferior, o que gera descrédito do interessado em galgar os trâmites administrativos antes de procurar o Judiciário (FORTINI; PEREIRA; CAMARÃO, 2012, p.212)

126 "Pode, efetivamente, a autoridade hierarquicamente superior conferir novo entendimento às mesmas normas que serviram de suporte a decisão recorrida, diferente daquele que havia sido dado pelo órgão a ela subordinado. Não se configura, nessa situação, a aplicação retroativa de nova interpretação - o que violaria o art. $2^{\circ}$, XIII, da Lei 9.784/1999" (DALLARI; FERRAZ, 2012, p. 300).

127 "Não é demais repetir que a decisão do recurso deve considerar as alegações e os documentos constantes do processo, conforme determina o art. $3^{\circ}$, III, da Lei 9.784/99, e deve ser criteriosamente motivada, nos termos do art. 50. A falta de motivação ou sua insuficiência ou incongruência geram nulidade da decisão proferida no recurso" (DALLARI; FERRAZ, 2012, p. 303)
} 
A modificação consiste na decisão recursal cujo conteúdo é a alteração parcial ou integral da decisão original. Em outras palavras, a autoridade administrativa decide no sentido do provimento parcial ou total do recurso administrativo, com o acolhimento parcial ou total do pedido apresentado (CARVALHO FILHO, 2013, p.323) ${ }^{128}$.

Essas alterações produzidas no conteúdo da decisão original podem ser de natureza fática ou de natureza normativa. Na hipótese em que ocorrer nova apreciação da matéria de fato - considerando-se as alegações escritas e orais, a apresentação de provas, o surgimento de novos fatos e circunstâncias relevantes - a modificação será considerada de natureza fática. Por sua vez, na situação em que a autoridade administrativa alterar o entendimento quanto à interpretação de determinado dispositivo normativo, então a decisão recursal modificativa será considerada de natureza normativa. Contudo, é fundamental destacar que se a modificação quanto ao entendimento de determinado dispositivo normativo determinar efeitos no patrimônio jurídico do cidadão, causando interferência direta ou indireta em direitos e interesses individuais, então a autoridade superior competente deverá necessariamente assegurar aos envolvidos - aqueles que tenham tido seu patrimônio jurídico afetado - o contraditório e a ampla defesa previamente a sua decisão (DALLARI; FERRAZ, 2012, p. 300) ${ }^{129}$. Além disso, a modificação também pode consistir em mero aclaramento ou em uma complementação da decisão original (MAHARA; NOHARA, 2009, p. 406) ${ }^{130}$.

A questão mais relevante concernente à modificação é a obrigatoriedade da motivação na decisão recursal que pretender a alteração do conteúdo da decisão original, expondo de maneira clara, direta e coerente os argumentos de fato e de direito que conduziram à solução diferente da originalmente adotada

Embora frequentemente a modificação seja feita buscando o benefício da situação jurídica do cidadão, haverá casos em que a autoridade superior competente adotará decisão em que ocorra a piora da situação jurídica desse cidadão. A hipótese de reformatio in pejus nos recursos administrativos será examinada em momento oportuno.

\footnotetext{
128 "Toda decisão que não mantenha integralmente os mandamentos contidos na decisão recorrida tem natureza modificativa" (MAHARA; NOHARA, 2009, p. 406).

129 É importante salientar que se a modificação no entendimento quanto a interpretação restringir-se a efeitos meramente internos ao âmbito administrativo, haverá apenas a obrigatoriedade de criteriosa motivação da decisão fundamentada nessa nova interpretação.

130 "Note-se, outrossim, que a decisão de modificação pode consistir em um aclaramento ou uma complementação da decisão anterior. Nessa hipótese, a decisão modificativa do recurso administrativo se assemelha à decisão dos embargos de declaração no processo judicial" (MAHARA; NOHARA, 2009, p. 406).
} 


\subsubsection{Anulação e revogação}

As decisões supressivas compreendem as decisões recursais em que ocorre a extinção do ato decisório original por meio de sua anulação ou revogação. Particularmente, as decisões supressivas se destacam das demais por serem o resultado de uma rediscussão global do processo administrativo original em razão de questões de ilegalidade e/ou inconveniência e inoportunidade do ato decisório a quo. Nesse sentido, frequentemente o juízo recursal extrapola os limites apresentados no recurso administrativo justamente pela identificação de questões concernentes ao interesse público, ainda que essa conduta venha a implicar numa situação menos benéfica ao cidadão-parte. Trata-se fundamentalmente da expressão prática do caráter de controle administrativo do recurso administrativo.

Observe-se a tabela comparativa abaixo:

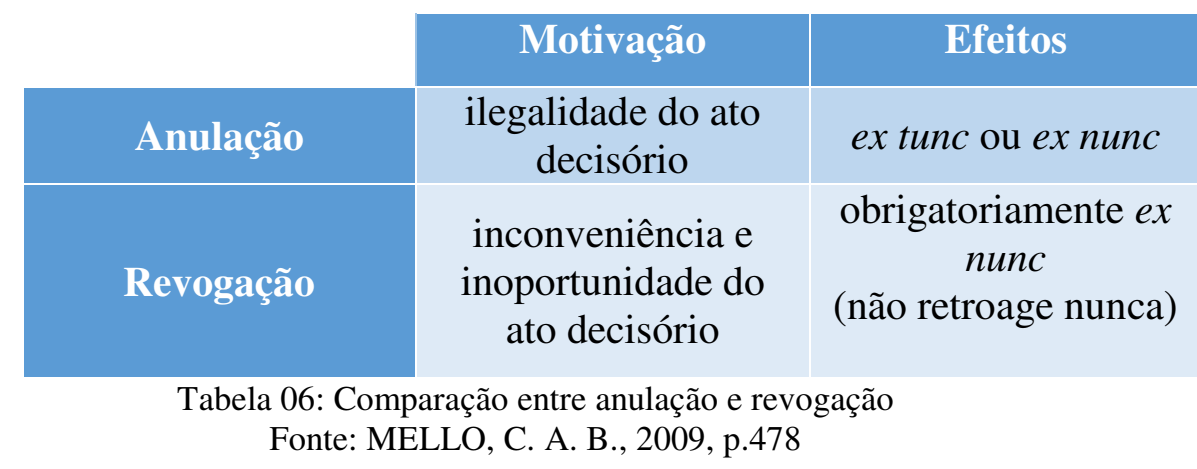

As decisões supressivas por anulação objetivam a exclusão parcial ou total do ordenamento jurídico dos atos decisórios praticados em desconformidade com as prescrições jurídicas (MELLO, C.A.B., 2009, p. 454) ${ }^{131}$, ou seja, o enfoque do juízo recursal em que houve a pronúncia de decisão por anulação é a análise da legalidade do ato decisório original. Dessa forma, os efeitos advindos da decisão por anulação podem operar tanto desde o momento da decisão original quanto do momento da decisão recursal, devendo ser analisado a conveniência dessa escolha com base no caso concreto.

A anulação consiste em um poder-dever da autoridade administrativa, motivo pelo qual a decisão recursal por anulação não constitui simples faculdade do agente público. Assim, havendo a identificação de ilegalidade no ato administrativo decisório, deve a autoridade superior competente imediatamente extinguir parcial ou integralmente a

131 “A noção de invalidade é antiética à de conformidade com o Direito (validade)" (MELLO, C.A.B., 2009, p. 454). 
decisão original sob pena de crime de prevaricação (MARRARA; NOHARA, 2009, p. 406). Note-se, porém, que por questões de economia e eficiência processual, deve a autoridade superior competente esforçar-se no sentido de verificar a existência de atos processuais que possam, não obstante a nulidade da decisão original, ser mantidos, de maneira que sempre que houver a possibilidade de convalidação - em detrimento da anulação - o agente público deverá adotar essa solução prática (MAHARA; NOHARA, 2009, p. 407).

Por sua vez, a revogação constitui a decisão recursal em que há a extinção do ato decisório original por razões de inconveniência e inoportunidade. $\mathrm{Na}$ realidade, a revogação atinge uma decisão originalmente editada em conformidade com a lei, em decorrência da identificação de elementos que violam a conveniência e oportunidade da prática desse ato decisório original, motivo pelo qual os efeitos da revogação são considerados a partir da própria revogação (DI PIETRO, 2011, p. 252). Deve-se, entretanto, salientar a existência de regras práticas quanto à possibilidade de revogação do ato decisório originalmente praticado, quais sejam: (i) os atos decisórios vinculados não são passíveis de revogação; (ii) os atos decisórios cujos efeitos já se esgotaram não são revogáveis justamente em razão de sua natureza; (iii) os atos decisórios não podem ser revogados por autoridade superior que não mais possui competência para tanto (DI PIETRO, 2011, p. 252).

Infelizmente, ainda é bastante frequente a situação em que a autoridade superior competente apenas limita-se à reapreciação dos aspectos formais da decisão original, deixando de analisar os elementos que possam afetar a conveniência e oportunidade da prática do ato decisório, fato que, consequentemente, acaba por estabelecer situações limitantes aos direitos e garantias fundamentais do cidadão, assim como o atendimento ao interesse público. Portanto, tão mais ampliativo de direitos será o exercício do juízo recursal quanto a autoridade superior competente não se limitar à mera apreciação das formalidades do ato decisório, buscando verdadeiramente desenvolver uma análise das questões de mérito que conduziram a autoridade administrativa $a$ quo a adotar determinada decisão com relação ao pedido que inicialmente lhe fora apresentado.

\subsection{A reformatio in pejus na decisão recursal}

O recurso administrativo, como já visto, constitui um mecanismo de controle administrativo, cuja finalidade é a readequação do ato administrativo decisório aos 
padrões de legalidade ou o realinhamento de questões relativas à oportunidade e conveniência da prática desse ato. Portanto, o recurso administrativo não se limita tão somente a ser um instrumento de questionamento da decisão original, mas representa a possibilidade de realização do interesse público por meio da defesa de direitos e garantias individuais, coletivos e difusos ao permitir que o ato administrativo decisório seja reapreciado com o objetivo de eliminar arbitrariedades ou ilegalidades que a autoridade administrativa possa ter cometido.

Se o recurso administrativo volta-se a defender interesses de ordens diversas, não se restringindo apenas à insatisfação do cidadão-parte em relação à decisão adotada pela autoridade administrativa, então é possível que a decisão recursal - em toda e qualquer hipótese - possa apresentar conteúdo que venha a agravar ou prejudicar a situação jurídica dos interessados nessa decisão? Em outras palavras, é aceita ou permitida a reformatio in pejus no processo administrativo federal?

A expressão reformatio in pejus faz referência ao brocardo processualista penal "tantum devolutum quantum appellatum", cujo significado esclarece que, embora a apelação permita o reexame da matéria decidida na sentença, o efeito devolutivo não opera plenamente, de modo que do julgamento em instância superior não poderá resultar decisão desfavorável àquele que apresentou a apelação (GRECO FILHO, 2009, pp. 337338). Assim, no direito processual penal não é possível que o juízo recursal agrave a situação jurídica do réu, exatamente em decorrência do fato da devolução da matéria ser estritamente limitada ao pedido elaborado pelo requerente.

Se no direito processual penal o efeito devolutivo da matéria recursal assegura ao réu a proteção quanto ao agravamento de sua situação jurídica, o que se verifica no direito processual administrativo é a possibilidade da reformatio in pejus. $\mathrm{O}$ art. 64, parágrafo único da Lei Federal n. 9.784/99 demonstra a fundamental importância da proteção e promoção dos interesses públicos ao possibilitar que a decisão recursal que objetive restabelecer os padrões de legalidade ou privilegie questões de oportunidade e conveniência na prática do ato decisório venha manifestamente a impor ônus mais grave ao recorrente, desde que atendidos os requisitos efetivadores do devido processo legal administrativo. Em suma, desde que a autoridade administrativa obrigatoriamente cientifique o cidadão-parte da sua intenção de agravamento da situação jurídica, para que este possa se manifestar e exercer o contraditório e a ampla defesa, poderá ocorrer a reformatio in pejus na decisão recursal, conforme determina o art. 64, parágrafo único da Lei n. 9.784/99. 
Contudo, é bastante relevante destacar que o momento correto para a apresentação da manifestação do cidadão-parte em relação aos elementos justificadores do agravamento da decisão é necessariamente aquele imediatamente anterior a decisão recursal, por uma questão mais do que óbvia de lógica processual: não há propósito em uma manifestação a respeito de uma questão já solucionada. Ademais, manifestações oferecidas posteriormente à decisão recursal poderiam significar a apresentação de pedido de reconsideração ou a interposição de outro recurso administrativo (MARRARA; NOHARA, 2009, p.409).

Ainda, a autoridade superior competente deverá evidenciar previamente a sua decisão os elementos que orientam seu posicionamento pelo agravamento da situação jurídica do cidadão-parte (CARVALHO FILHO, 2013, p. 327). Além disso, se a autoridade superior competente vier a mencionar outros fundamentos após a manifestação do recorrente, terá novamente o dever de cientificar o cidadão-parte, concedendo-lhe nova possibilidade de manifestação sendo lhe assegurando, uma vez mais, o exercício do contraditório e da ampla defesa (CARVALHO FILHO, 2013, p. 327).

O entendimento da autoridade superior competente não pode, em hipótese alguma, ser formulado sem a manifestação do recorrente, pois essa situação significaria violação ao devido processo legal administrativo. Assim, a viabilidade da reformatio in pejus está condicionada à plenitude da satisfação do contraditório e da ampla defesa, sob pena da decisão recursal se instrumentalizar como meio de propagação de condutas recheadas de arbitrariedade (FORTINI; PEREIRA; CAMARÃO, 2012, p. 213) ${ }^{132}$. Entretanto, essa cientificação não pode significar a possibilidade de desistência do recurso administrativo, ainda que essa hipótese não seja vedada pela Lei Federal n. 9.784/99 (BUENO, 2006, p. 213), pois traduziria a desistência da própria chance de realização do interesse público.

Há, contudo, exceção à regra da reformatio in pejus no processo administrativo, contida no art. 65, parágrafo único da Lei Federal n. 9.784/99, que estabelece que "da revisão do processo não poderá resultar agravamento da sanção", isto é, nos processos sancionatórios em que ocorrer a revisão administrativa da decisão original não poderá ocorrer o agravamento da penalidade aplicada. Essa proibição deve-se justamente pela

\footnotetext{
132 "Se, por um lado, há como defender a viabilidade e até a imperiosidade da mudança de posicionamento administrativo, mesmo que com maior sacrifício a ser sentido pelo recorrente, ao argumento de que se cuidaria de decorrência do dever de autotutela, bem como corolário do princípio da legalidade, não há como deixar de considerar a influência que tal possibilidade acarreta em termos de ampla defesa" (FORTINI; PEREIRA; CAMARÃO, 2012, p. 213)
} 
característica sancionatória da revisão administrativa, mimetizando aquilo que acontece no âmbito do direito processual penal (MARRARA; NOHARA, 2009, p. 408).

Apresentados os recursos administrativos e outras espécies recursais contidas na Lei Federal n. 9.784/1999, o próximo capítulo destina-se à análise dos recursos administrativos em legislações específicas. 


\title{
DIAGNÓSTICO DAS GARANTIAS RECURSAIS NAS PRINCIPAIS LEGISLAÇÕES ADMINISTRATIVISTAS FEDERAIS
}

\begin{abstract}
SUMÁRIO: 1. Lei dos Servidores Públicos Federais; 1.1. Arranjo normativo e dispersão temática; 1.2. As garantias recursais na Lei Federal n. 8.112/90: tipologia recursal e regras específicas dessa legislação; 1.2.1. Grupo I: direito de petição; 1.2.2. Grupo II: processo administrativo disciplinar; 1.3. Considerações acerca da Lei dos Servidores Públicos Federais - 2. Lei de Licitações e Contratos Administrativos; 2.1. Arranjo normativo e dispersão temática; 2.2. As garantias recursais na Lei Federal n. 8.112/90: tipologia recursal e regras específicas dessa legislação; 2.3. Considerações acerca da Lei de Licitações e Contratos Administrativos - 3. Legislações infraconstitucionais básicas das agências reguladoras federais; 3.1. Agências reguladoras instituídas previamente a Lei Federal n. 9.784/99; 3.2. Agências reguladoras instituídas posteriormente a Lei Federal n. 9.784/99; 3.3. Considerações acerca das legislações infraconstitucionais básicas das agências reguladoras.
\end{abstract}

\section{Lei dos Servidores Públicos Federais}

Anteriormente à promulgação da $\mathrm{CF} / 88$ vigorava no ordenamento jurídico brasileiro o regime dualista de contratação (estatutário e celetista), em que a contratação para cargos de maior relevância regulava-se por meio do Estatuto dos Funcionários Públicos e a contratação para os cargos menos importantes era orientado por meio das regras da Consolidação das Leis de Trabalho (CLT). Nesse sentido, o art. 39 CF/88 133 ao estabelecer que os entes federativos, dentro do âmbito de sua competência, deveriam instituir regime jurídico único e planos de carreira para os servidores da administração direta, autarquias e fundações públicas foi responsável por determinar a extinção desse regime dualista de contratação até então vigente. Assim, em atendimento ao dispositivo constitucional em questão, editou-se durante o mandato do presidente Fernando Collor de Mello (1990-92) a Lei Federal n. 8.112 de 11 de dezembro de 1990, cujo conteúdo dispõe sobre o Regime Jurídico Único dos Servidores Públicos Civis da União e opta pelo regime estatutário de servidorismo público federal ${ }^{134}$.

\footnotetext{
${ }^{133}$ Em sua redação original, antes da alteração ocorrida em razão da publicação da Emenda Constitucional n.19/98, o art. 39 estabelecia que “ [a] União, os Estados, o Distrito Federal e os Municípios instituirão, no âmbito de sua competência, regime jurídico único e planos de carreira para os servidores da administração pública direta, das autarquias e das fundações públicas".

134 A Lei Federal n. 8112/90 entrou em vigor no dia seguinte, alcançando indiscriminadamente todos os servidores públicos estatutários submetidos à Lei n. 1.711/52 que estivessem, até aquele momento, em pleno exercício de cargos na administração direta, autarquias, fundações públicas e nos poderes legislativo e judiciário da União. Além disso, a nova sistemática também atingiu os servidores celetistas, sendo responsável por estabelecer um processo de estatutarização dos vínculos dos servidores públicos federais. Contudo, não se pode deixar de mencionar que a Lei Federal n. 8.112/90 não alcançou os empregados de empresas públicas - Caixa Econômica Federal -, os empregados das sociedades de economia mista - a
} 
Considerando-se a importância da Lei Federal n. 8.112/90 para a organização da administração pública federal, vez que objetiva a regulamentação de diversos aspectos da relação entre os agentes públicos federais e os entes públicos federais em que esses agentes estão lotados, é essencial examinar-se quanto os princípios e regras dessa legislação são protetivos em relação a questões relacionadas com o devido processo legal administrativo, especialmente no que se refere à extensão e possibilidade de questionamento das decisões por meio de recursos e outros instrumentos recursais.

\subsection{Arranjo normativo e dispersão temática}

Composta por 253 (duzentos e cinquenta e três) artigos, a Lei Federal n. 8.112/90 apresenta uma temática bastante diversificada, abordando inúmeros assuntos relacionados ao regime jurídico dos servidores públicos federais estruturados em nove títulos, vinte e oito capítulos, cinquenta e três seções e treze subsecções.

Especificamente quanto ao processo administrativo no âmbito das relações jurídicas entre os servidores públicos federais e a administração pública federal, a Lei Federal n. 8.112/90 apresenta 52 (cinquenta e dois) artigos relativos às regras que orientam os diversos atos e procedimentos instituidores do processo administrativo, arranjados da seguinte maneira:

Petrobrás e o Banco do Brasil, que por serem pessoas de direito privado, sempre foram regidos por contrato de trabalho segundo regras da Consolidação das Leis do Trabalho (CLT). Da mesma forma, essa lei não regula os militares - possuidores de regime especial e próprio - nem os membros do judiciário e do Ministério Público - que também têm regimes jurídicos especiais e próprios. Por fim, também não abrangeu os contratados por prazo determinado. 


\begin{tabular}{|l|l|}
\hline Título III: Dos Direitos e Vantagens \\
$\begin{array}{l}\text { Capítulo VIII: Do Direito de Petição } \\
\text { Tútulo V: Do Processo Administrativo } \\
\text { Disciplinar }\end{array}$ \\
Capítulo I: Disposições Gerais \\
Número de artigos: 04 artigos \\
Capítulo II: Do Afastamento Preventivo \\
Número de artigos: 01 artigos \\
Capítulo III: Do Processo Disciplinar \\
Número de artigos: 05 artigos \\
\\
Seção I: Do Inquérito \\
Número de artigos: 14 artigos \\
\\
Seção II: Do Julgamento \\
Número de artigos: 07 artigos \\
\\
Seção III: Da Revisão do Processo \\
Número de artigos: 09 artigos
\end{tabular}

Tabela 07: Arranjo normativo das regras de processualidade administrativa na Lei Federal n. 8.112/90 Fonte: elaboração própria a partir da Lei Federal n. 8.112/90

Em termos comparativos, a Lei Federal n. 8.112/90 oferece mais dispositivos normativos de caráter material do que regras relacionadas a processualidade administrativa, o que significa dizer que somente (aproximadamente) 20,5\% dos artigos da Lei Federal n. 8.112/90 são voltados para as regras que orientam o processo administrativo naquilo que concerne o regime do servidor público federal. Observe-se o gráfico abaixo para melhor compreensão da dispersão dessa diferença: 


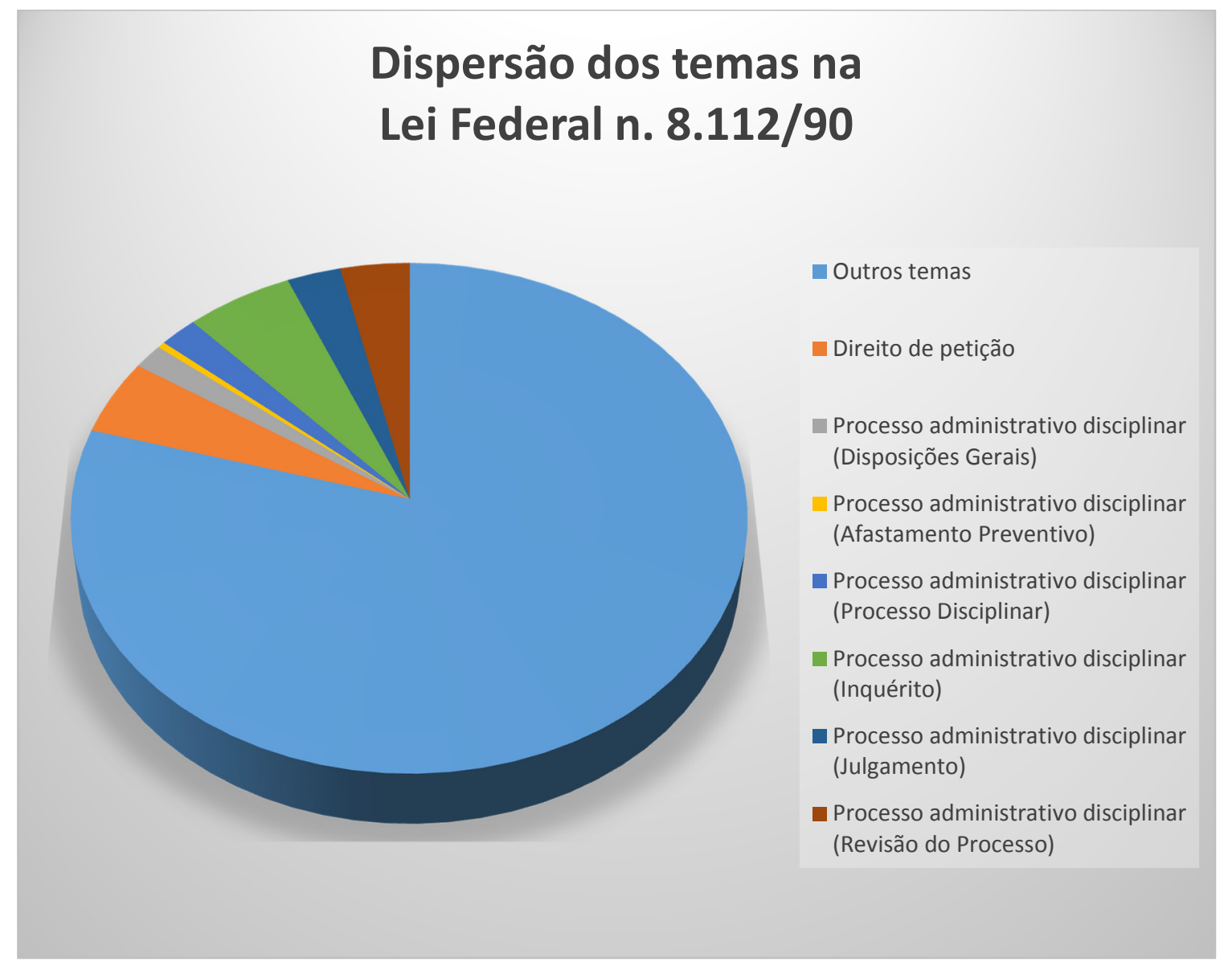

Gráfico 03: Dispersão dos temas na Lei Federal n. 8.112/90

Fonte: elaboração própria a partir da Lei Federal n. 8.112/90

Dentro exclusivamente do universo de normas jurídicas processuais da Lei Federal n. 8.112/90, é possível verificar uma predominância de dispositivos normativos relativos regulamentadores do processo administrativo disciplinar, sendo, portanto, perceptível a especialização em regras cuja finalidade é majoritariamente a apuração de infrações disciplinares e aplicação de penalidades aos servidores públicos federais. Em termos numéricos, totalizam-se 40 (quarenta) artigos unicamente dirigidos ao processo administrativo disciplinar contra apenas 12 (doze) artigos referentes a outros conteúdos processuais, ou seja, ao passo que aproximadamente $76 \%$ dos 52 (cinquenta e dois) artigos de temática processual da Lei Federal n. 8.112/90 tratam do processo administrativo processual, tão somente (aproximadamente) $24 \%$ são destinados a apresentar orientações diversas quanto a processualidade administrativa. Sem dúvida alguma há uma maior preocupação com questões de caráter disciplinar.

Essa perspectiva adotada pela Lei Federal n. 8.112/90 é suficiente para representar um decréscimo na efetivação do conteúdo constitucional quanto aos direitos e garantias fundamentais do devido processo legal administrativo em matéria especificamente 
recursal? Os dados apresentados são insuficientes, pois apresentam somente uma perspectiva formal dessa legislação, sem examinar seu conteúdo. Dessa forma, é necessário um aprofundamento na análise, buscando investigar o teor normativo desses artigos cujo conteúdo emana regras processuais administrativas.

\subsection{As garantias recursais na Lei Federal n. 8.112/90: tipologia recursal e regras específicas dessa legislação.}

Assim como a maioria dos regramentos administrativos, os diversos assuntos regulados pela a Lei Federal n. 8.112/90 quanto ao servidorismo público federal são dispostos de maneira bastante difusa, sendo possível a identificação de agrupamentos de artigos arranjados conforme uma lógica interna da própria legislação. Em relação ao processo administrativo, verifica-se a existência de dois agrupamentos principais: direito de petição e processo administrativo disciplinar. Enquanto que o grupo I, denominado de "direito de petição", aborda questões mais genéricas a respeito do processo administrativo, o grupo II, denominado de "processo administrativo disciplinar", voltase quase que exclusivamente para as regras sancionatórias.

A seguir, examinar-se-á cada um desses agrupamentos.

\subsubsection{Grupo I: direito de petição}

O primeiro agrupamento de dispositivos normativos relacionados com o processo administrativo no âmbito dessa legislação recebe a denominação de "Direito de Petição" (Capítulo VIII do Título III da Lei Federal n. 8.112/90) e é composto por onze artigos (art. 104 ao art. 115), sendo seis artigos diretamente relativos a disciplinas dos recursos administrativos (art. 106 ao art. 111).

\section{a) Reconsideração}

O pedido de reconsideração é o requerimento dirigido à autoridade responsável pela expedição do ato administrativo ou da primeira decisão administrativa (art. 106), podendo ser interposto em até 30 (trinta) dias após a ciência ou publicação desse ato ou 
decisão administrativa (art.108) ${ }^{135}$, sendo que sua interposição interrompe a prescrição administrativa desse ato ou decisão (art. 111). Além disso, o pedido de reconsideração deve ser despachado em até 05 (cinco) dias (art. 106, parágrafo único) e decidido em até 30 (trinta) dias após sua interposição (art. 106, parágrafo único), sendo que os efeitos de sua decisão retroagem até a data do ato ou decisão impugnado (art. 109, parágrafo único). Ainda, é relevante salientar que nenhum dos prazos listados pelo agrupamento são prorrogáveis (art. 115).

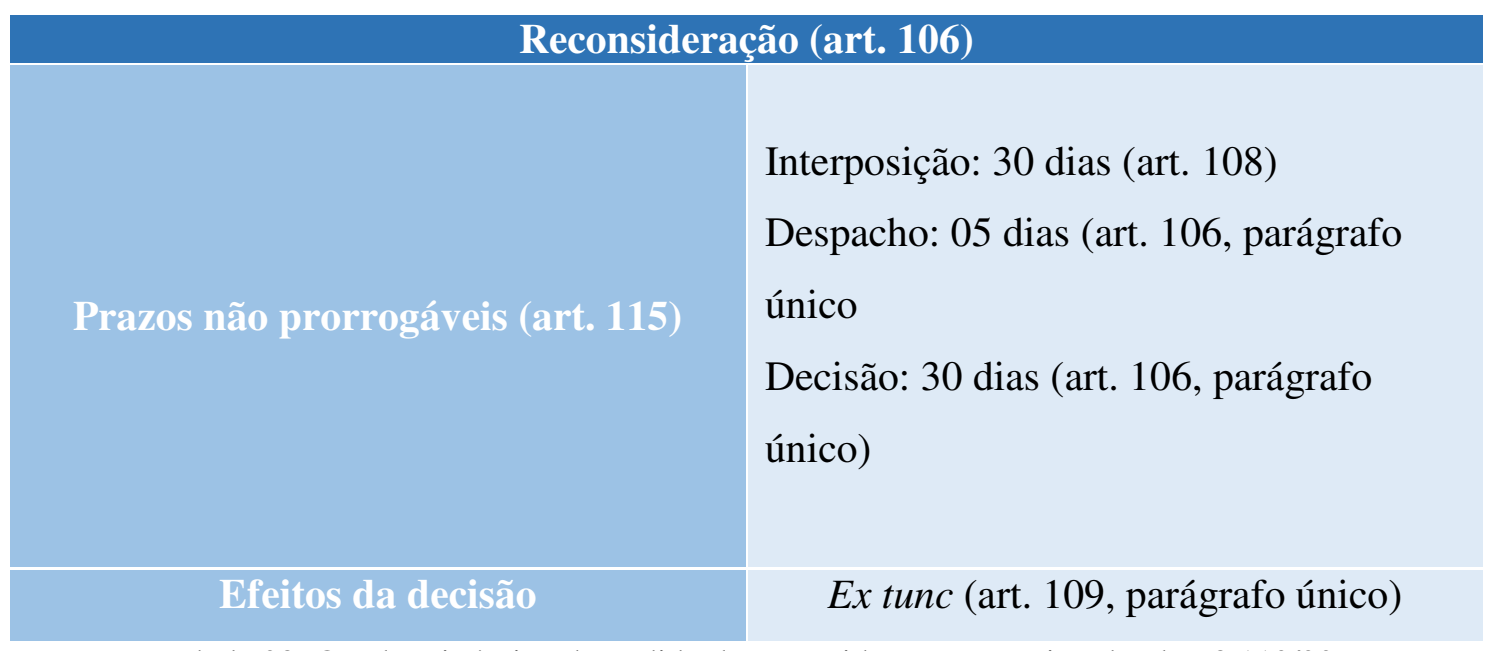

Tabela 08: Quadro sinóptico do pedido de reconsideração na Lei Federal n. 8.112/90 Fonte: elaboração própria a partir da Lei Federal n. 8.112/90

Comparativamente à Lei Federal n. 9.784/99, a Lei Federal n. 8.112/90 há de se destacar semelhanças e diferenças.

A Lei Federal n. 9.784/99 estabelece um prazo 20 (vinte) dias menor para interposição do pedido de reconsideração. Nesse sentido, o prazo de 30 (trinta) dias para

\footnotetext{
135 Nesse sentido: DIREITO ADMINISTRATIVO. MANDADO DE SEGURANÇA. SERVIDOR PÚBLICO. PEDIDO DE RECONSIDERAÇÃO. CONTAGEM DO PRAZO. CIÊNCIA DO ATO IMPUGNADO. CONCESSÃO DE EFEITO SUSPENSIVO. PRERROGATIVA DA ADMINISTRAÇÃO. SEGURANÇA CONCEDIDA EM PARTE. 1. O servidor público federal tem o prazo de 30 (trinta) dias para interpor pedido de reconsideração ou recurso do ato que lhe seja desfavorável, de acordo com o art. 108 da Lei 8.112/90. 2. Sobressai dos autos que o impetrante "Professor do Centro Federal de Educação Tecnológica do Espírito Santo (CEFET/ES)" tão-somente em 27/9/06 teve ciência da penalidade que lhe foi imposta, não obstante ela tenha sido publicada no Boletim de Serviço em 23/6/06. Desse modo, é tempestivo o pedido de reconsideração interposto em 26/10/06. 3. Constitui prerrogativa discricionária da autoridade competente o recebimento do pedido de reconsideração ou do recurso no efeito suspensivo, consoante inteligência dos arts. 106 e 109 da Lei 8.112/90. Em consequência, não cabe ao Poder Judiciário usurpar competência atribuída por lei à Administração. 4. O pedido de reconsideração não se confunde com o recurso hierárquico. O primeiro é julgado pela própria autoridade que proferiu o ato impugnado. $\mathrm{O}$ segundo, pela autoridade hierarquicamente superior. No caso, cuida-se de pedido de reconsideração, razão pela qual incabível a determinação para que o Ministro de Estado da Educação o encaminhe para o Presidente da República. 5. Segurança concedida em parte. (SUPERIOR TRIBUNAL DE JUSTIÇA. Mandado de Segurança n. 12.621 DF 2007/0025772-4, Relator: Ministro Arnaldo Esteves Lima, j. 26 mar 2008)
} 
a interposição do pedido de reconsideração faz com que a Lei Federal n. 8.112/90 possibilite a apresentação de um requerimento mais bem elaborado e melhor fundamentado, ocasionando a ampliação da possibilidade postulatória do cidadão-parte insatisfeito com a decisão desfavorável no sentido de uma defesa mais bem articulada e mais profundamente instrumentalizada. Além disso, o prazo conferido à autoridade decisória também é maior, sendo 25 (vinte e cinco) dias a mais para que se exponha o resultado do juízo recursal, ou seja, novamente a Lei Federal n. 8.112/90 confere uma ampliação das garantias relacionadas ao devido processo legal administrativo, pois proporciona a oportunidade da autoridade decisória proceder a uma análise mais detida e melhor ponderada, podendo resultar num alargamento dos direitos do cidadão-parte.

Há, contudo, uma questão interessante. O art. 107, inciso I estabelece que do "indeferimento do pedido de reconsideração" pode levar ao entendimento de que o pedido de reconsideração não deve ser automaticamente encaminhado à autoridade administrativa superior em caso de não acolhimento do pedido. Tendo em vista que, na maioria das vezes, os envolvidos - autoridade administrativa e partes - nem sempre possuem profundos conhecimentos de técnica processual, é possível que se confira a confirmação da primeira decisão caráter de novação decisória, abrindo-se novo prazo para interposição do recurso administrativo. $\mathrm{Na}$ verdade, fundamentalmente não se pode compreender nesse dispositivo a possibilidade de impedimento do prosseguimento da via recursal, devendo a autoridade administrativa hierarquicamente superior proceder ao juízo recursal como forma de cumprimento de suas obrigações administrativas.

O fato do efeito da decisão do pedido de reconsideração retroagir à data do ato ou decisão impugnado pode ser bastante interessante em termos de realização de garantias e direitos fundamentais do cidadão-parte, vez que o efeito suspensivo do pedido de reconsideração é excepcional, devendo ser atribuído pela autoridade administrativa mediante requerimento ${ }^{136}$, de modo que a decisão ou ato administrativo vai tendo efeitos

\footnotetext{
${ }^{136}$ Nesse sentido: MANDADO DE SEGURANÇA. ADMINISTRATIVO. POLICIAL RODOVIÁRIO FEDERAL. PROCESSO ADMINISTRATIVO. PENDÊNCIA DE PEDIDO DE RECONSIDERAÇÃO. EFEITO DEVOLUTIVO. POSSIBILIDADE DE EXECUÇÃO DA IMPOSIÇÃO. PRIMEIRO PROCEDIMENTO ADMINISTRATIVO ANULADO. TESTEMUNHOS RATIFICADOS NO SEGUNDO PROCEDIMENTO REGULAR. DIVERGÊNCIA ENTRE O RELATÓRIO DA COMISSÃO E O DA CONSULTORIA JURÍDICA DO MINISTÉRIO DA JUSTIÇA. AGRAVAMENTO DA PENA. POSSIBILIDADE. FUNDAMENTAÇÃO. ART. 168 DA LEI 8.112/90. Em geral os recursos administrativos só detêm o efeito devolutivo (arts. 106 e 109 da Lei 8.112/90), sendo juízo da autoridade recebê-lo no suspensivo. Desnecessidade de se aguardar o desfecho do recurso para a execução da penalidade imposta após regular procedimento administrativo. Inverídica a alegação do impetrante de que a Comissão Processante se utilizara de testemunhos e depoimentos prestados no curso do primeiro procedimento administrativo declarado nulo. Houve regular procedimento no segundo processo, com novas
} 
jurídicos tão logo é expedido, o que pode causar prejuízo ao cidadão-parte. Portanto, o efeito retroativo da decisão do pedido de reconsideração teria, em teoria, a capacidade de recompor esses prejuízos infligidos à ordem jurídica do cidadão-parte.

\section{b) Recursos administrativos}

$\mathrm{O}$ art. 107 apresenta as hipóteses de cabimento de recurso administrativo (art. 107, I e II) e suas condições de direcionamento (art. $107, \S 1^{\circ}$ ) e encaminhamento (art. 107, $\S 2^{\circ}$ ). Segundo esse artigo, caberá recurso administrativo na hipótese de "indeferimento do pedido de reconsideração" (art. 107, I) e contra as "decisões sobre os recursos sucessivamente interpostos" (art. 107, II), sendo o requerimento dirigido à autoridade hierarquicamente superior àquela que prolatou o ato ou decisão administrativa (art. 107, $\left.\S 1^{\circ}\right)$, devendo ser esse requerimento encaminhado por intermédio da autoridade ao qual se subordine o cidadão-parte (art. $\left.107, \S 2^{\circ}\right)$.

O prazo para interposição do recurso administrativo é de 30 (trinta) dias (art. 108), podendo o recurso ser recebido com efeito suspensivo se assim concedido pela autoridade administrativa (art. 109). Assim como no caso do pedido de reconsideração, os prazos são improrrogáveis (art. 115).

O direito de recorrer está sujeito à prescrição nas seguintes hipóteses e de acordo com os seguintes prazos: (i) nos casos de "atos de demissão e de cassação de aposentadoria ou disponibilidade, ou que afetem interesse patrimonial e créditos resultantes das relações de trabalho" em até cinco anos e (ii) nos demais casos em até 120 (cento e vinte) dias.

Em relação à Lei Federal n. 9.784/99, novamente deve-se destacar o alargamento do prazo para interposição do recurso em 20 (vinte) dias, ou seja, o interessado insatisfeito com a decisão que lhe foi desfavorável poderá apresentar recurso administrativo dentro do prazo máximo de 30 (dias). De resto, deve-se, também, fazer breve comentário quanto às hipóteses de prescrição, que evidenciam, mais uma vez, a preocupação do legislador

\footnotetext{
intimações e depoimentos, nos quais as testemunhas ratificaram suas alegações, mas não deixaram de narrar todo o acontecido novamente. Em tais testemunhos foram baseadas as conclusões da Consultoria Jurídica. É possível à autoridade julgadora agravar a penalidade imposta pela Comissão Processante, desde que seu relatório esteja contrário à prova dos autos, e o agravamento se dê de forma motivada (art. 168 da Lei $n^{\circ}$ 8.112/90). Esse foi exatamente o caso dos autos. Ordem denegada. (SUPERIOR TRIBUNAL DE JUSTIÇA. Mandado de Segurança n. 8890 DF 2003/0012848-8, Relator: Ministro José Arnaldo da Fonseca, j em. 10 dez 2003)
} 
em disciplinar questões ligadas à aplicação de penalidades, como a demissão e cassação, aos servidores públicos federais.

\subsubsection{Grupo II: processo administrativo disciplinar}

Por sua vez, o Grupo II apresenta os artigos orientadores do processo administrativo disciplinar. São 40 (quarenta) dispositivos normativos, dentre os quais nove disciplinam a revisão do processo administrativo sancionatório em sede de servidorismo público federal.

A revisão administrativa consiste no reexame do processo disciplinar em razão da apresentação de "fatos novos ou circunstâncias suscetíveis de justificar a inocência do punido ou a inadequação da penalidade aplicada" (art. 174, caput), por meio da apresentação de requerimento elaborado pelo servidor (art. 174, caput), seus familiares em caso de seu falecimento ( $\operatorname{art} .174, \S 1^{\circ}$ ), ou curador em caso de incapacidade mental do servidor (art. 174, $\S 2^{\circ}$ ), bem como de ofício (art. 174, caput).

Tendo em vista que não basta a alegação de injustiça como fundamento para motivar o pedido de revisão do processo disciplinar (art. 176), conforme a Lei Federal n. 8.112/90, o ônus probatório é de responsabilidade daquele que requerer a revisão administrativa (art. 175), que poderá requerer dia e hora para produção de provas e contradita das testemunhas (art. 178, parágrafo único).

O requerimento da revisão administrativa deve ser encaminhado ao Ministro de Estado, que deverá autorizar a instauração do juízo revisional pela autoridade administrativa competente, ou seja, aquela que originou o processo administrativo disciplinar (art. 177, caput) para a designação da comissão revisora (art. 177, parágrafo único), que possuirá 60 (sessenta) dias para a conclusão de seus trabalhos (art. 179). A atividade da comissão revisora regular-se-á pelas mesmas normas e procedimentos da comissão do processo disciplinar (art. 180).

A revisão administrativa não constitui processo autônomo, devendo ser apensada ao processo disciplinar originário (art. 178).

O julgamento do requerimento contendo o pedido de revisão administrativa caberá à autoridade responsável pela aplicação da penalidade (art. 181, caput), sendo o prazo para a decisão de 20 (vinte) contados da data de recebimento do processo (art. 181, parágrafo único). Finalmente, se a revisão administrativa for julgada procedente pela autoridade administrativa, então a penalidade aplicada deverá ser declarada sem efeitos, 
restabelecendo-se todos os direitos do servidor público federal (art.182). Destaque-se que a revisão administrativa, segundo a Lei Federal n. 8.112/90, não poderá ocasionar a reformatio in pejus da decisão que aplicou a penalidade (art. 182, parágrafo único) ${ }^{137}$.

$\mathrm{O}$ minucioso detalhamento apresentado pela Lei Federal n. 8.112/90 quanto à revisão administrativa aproximou-a enormemente das normas e procedimentos previstos pela Lei Federal n. 9.784/99 para o pedido de revisão do processo sancionatório. Dessa maneira, apenas se confirma o caráter protetivo da Lei Federal n. 8.112/90 quanto a questões envolvendo a aplicação de penalidades aos servidores públicos federais.

\subsection{Considerações acerca da Lei dos Servidores Públicos Federais}

O objetivo da Lei Federal n. 8.112/90 está relacionado com a implementação de um regime jurídico para os servidores públicos civis federais, pertencentes aos órgãos públicos da União, às autarquias federais e às fundações públicas federais, portanto, não se trata de uma legislação cuja finalidade seja exclusivamente disciplinar ou orientar os atos e procedimentos do processo administrativo dos servidores públicos federais. Podese afirmar, dessa forma, que a Lei Federal n. 8.112/90 vai muito além de um simples diploma normativo processual.

Tendo em vista que a Lei Federal n. 8.112/90 foi publicada nove anos antes da Lei Federal n. 9.784/99 - escolhida para efeitos comparativos quanto as garantias recursais

\footnotetext{
${ }^{137}$ Nesse sentido, veja-se o exemplo a seguir: "MANDADO DE SEGURANÇA. ADMINISTRATIVO. SERVIDOR PÚBLICO FEDERAL. PROCESSO ADMINISTRATIVO DISCIPLINAR. CUMPRIMENTO DA PENA DE SUSPENSÃO POR TRINTA DIAS, CONVERTIDA EM MULTA (ART. 130, § $2^{\circ}$, DA LEI 8.112/90). POSTERIOR REVISÃO DO PROCESSO. APLICAÇÃO DA PENA DE DEMISSÃO PELOS MESMOS FATOS. OCORRÊNCIA DE REFORMATIO IN PEJUS. SEGURANÇA CONCEDIA. 1. Discussão acerca da possibilidade de anulação parcial de processo findo, com sanção já cumprida, para aplicação de penalidade de demissão pelos mesmos fatos. 2. Rejeito a tese da preliminar de decadência do direito à impetração suscitada pela autoridade coatora, referendada pelo Parquet, pois, entre a publicação da Portaria Retificadora, ocorrida em 15 de fevereiro de 2006 (e-STJ fl. 80), e a impetração do writ (26.4.2006) não transcorreu o prazo do art. 23 da Lei 12.016/2009. 3. O que se tem aqui é anulação de processo findo, com sanção já cumprida, ou seja, uma revisão com reformatio in pejus, a qual está em sentido contrário à jurisprudência do STJ que proíbe o agravamento da penalidade imposta a servidor, após o encerramento do respectivo processo disciplinar, com o julgamento definitivo pela autoridade competente, como no caso dos autos em que já tinha sido cumprida a pena de suspensão, convertida em multa, quando veio nova reprimenda (demissão). Dentre outros precedentes: MS 11.554/DF, Rel. Ministro Og Fernandes, Terceira Seção, DJe 01/10/2013; MS 17.370/DF, Rel. Ministro Arnaldo Esteves Lima, Primeira Seção, DJe 10/09/2013; MS 10.950/DF, Rel. Ministro Og Fernandes, Terceira Seção, DJe 01/06/2012. 4. Incide, na espécie, o verbete sumular n. 19/STF: "[é] inadmissível segunda punição de servidor público, baseada no mesmo processo em que se fundou a primeira". 5. Segurança concedida para anular as Portarias n. 1.511 e 1.512, publicadas no D.O.U de 15 de fevereiro de 2006, do Ministro da Integração Nacional, e, por conseguinte, determinar a reintegração dos impetrantes no cargo que ocupavam antes da demissão, com repercussão financeira a partir da impetração" (SUPERIOR TRIBUNAL DE JUSTIÇA. Mandado de Segurança n. 11749 DF 2006/0083673-8, Relator: Ministro Benedito Gonçalves, j. 11 junho 2014).
} 
para essa sistematização dos recursos administrativos nas legislações federais - é surpreendente a constatação da atualidade e da abrangência protetiva da Lei Federal n. 8.112/90 quanto às garantias de direitos fundamentais relativas ao devido processo legal administrativo. Praticamente não se verificam lacunas normativas a serem preenchidas subsidiariamente pela Lei Federal n. 9.784/99 e ainda se pode destacar a previsão de prazos mais extensos tanto para a interposição quanto para o julgamento dos recursos administrativos e de outras espécies recursais. Certamente esse cuidado no amparo aos direitos e garantias fundamentais deve ser em razão de, na maior parte das vezes, a aplicação das normas processuais da Lei Federal n. 8.112/90 ocorrer no campo dos processos administrativos sancionatórios, âmbito cujos bens jurídicos em jogo costumeiramente são considerados mais expressivos e significativos para a ordem jurídica dos envolvidos.

Caso na prática venha a se verificar limitações às garantias e direitos fundamentais dos interessados, certamente será necessária a análise da aplicação das normas e procedimentos dessa legislação pelo agente público investido na competência para a realização daquele processo administrativo (autoridade administrativa competente), pois a aplicação rigorosa da Lei Federal n. 8.112/90 é suficientemente hábil à promoção das condições necessárias para se efetivar, na maior medida possível, o devido processo legal administrativo e suas garantias processuais nos casos envolvendo servidorismo público federal.

\section{A Lei de Licitações e Contratos Administrativos}

Em termos de organização administrativa, sem dúvida alguma as legislações que dispõem sobre licitações e contratos administrativos sempre assumiram posição de destaque, em decorrência da importância dessa matéria para o cotidiano da Administração Pública. Assim, desde antes da formação da república, regras regulamentadoras das compras públicas já constavam do ordenamento jurídico brasileiro. O Decreto n. 2.926 de 14 de maio de 1862 pode ser apontado como a primeira legislação brasileira a apresentar normas e procedimentos para disciplinar as licitações, pois propõe regras para a regulamentação das arrematações dos serviços do Ministério da Agricultura, Comércio e Obras Públicas. Contudo, somente por meio do Decreto n. 4.536 de 28 de janeiro de 1922 - Código de Contabilidade da União (arts. 49 a 53) - é que se pode efetivamente verificar uma espécie de consolidação das regras licitatórias. Mais tarde, o Decreto-Lei n. 200 de 25 de fevereiro de 1967 (arts. 125 a 144), objetivando conferir maior eficiência 
às contratações públicas no âmbito da reforma administrativa federal, pode ser indicado como a legislação responsável pela sistematização das normas e procedimentos para as licitações. Por sua vez, o Decreto-Lei n. 2.300 de 21 de novembro de 1986 - atualizado pelo Decreto-Lei n. 2.348 e pelo Decreto-Lei n. 2.360, ambos de 1987 - instituiu o Estatuto Jurídico das Licitações e Contratos Administrativos, legislação que organizou normas gerais e especiais relacionadas com licitações e contratações administrativas. Entretanto, por intermédio da $\mathrm{CF} / 88$, que constitucionalizou o tema no capítulo referente à Administração Pública, é que as regras de licitações e contratos administrativos efetivamente passaram a corporificar uma obrigação inafastável para todos os entes públicos da administração pública direta e indireta (MEIRELLES, 2004, pp. 265-267).

A Lei Federal n. 8.666 de 21 de junho de 1993 - ao regulamentar o art. 37, XXI da $\mathrm{CF} / 88$ - consagrou diversas regras e princípios trazidos pelas leis anteriores, adaptando-os a sistemática da $\mathrm{CF} / 88$ e aos fatos sócio-políticos ocorridos na década de 90. Embora essa proteção constitucional conferida às regras e procedimentos licitatórios tenha sido enormemente relevante para a efetivação de diversos direitos e garantias dos cidadãos, foi a aplicação prática que possibilitou a superação de alguns princípios demasiadamente formalistas, responsáveis por estabelecer o privilégio absoluto da forma em detrimento do conteúdo ${ }^{138}$. Nesse sentido, a interpretação da Lei Federal n. 8.666/93 pelos tribunais superiores e pelos tribunais de contas também pode ser apontada como elemento determinante para a modificação das condições relacionadas com as licitações e contratações administrativas, pois auxilia na superação de uma tradição formalista clássica - mais centrada na forma do que na efetivação dos direitos e garantias individuais (JUSTEN FILHO, 2010, p.13).

Considerando-se a importância da Lei Federal n. 8.666/93 para a organização administrativa, bem como o fato da aplicação de diversas normas jurídicas dessa legislação ser efetivada por meio de processo administrativo, é fundamental para a sistematização dos recursos administrativos na legislação federal o exame das regras específicas contidas na Lei Federal n. 8.666/93.

\subsection{Arranjo normativo e dispersão temática}

\footnotetext{
${ }^{138}$ Segundo JUSTEN FILHO (2010, p.13), esse processo de aplicação da Lei Federal n. 8.666/93 - em que ocorre uma adaptação dos princípios formalistas à realidade prática - representa uma espécie de depuração legislativa.
} 
Com exceção ao capítulo específico - composto por apenas um único artigo (art. 109) - dos Recursos Administrativos, diferentemente da Lei de Servidores Públicos Federais, a Lei Federal n. 8.666/93 não possui títulos ou capítulos exclusivos para as normas de processo administrativo, dispersando algumas poucas regras processuais ao longo de determinados artigos. A finalidade dessa lei é o estabelecimento de elementos para a organização dos procedimentos da licitação ou da contratação. Nesse sentido, a aferição de dados mais precisos a respeito da dispersão temática na Lei Federal n. 8.666/93 demanda um esforço maior do pesquisador, que precisa separar do tema geral inscrito no artigo considerado a regra processual.

A Lei Federal n. 8.666/93 apresenta 126 (cento e vinte e seis) artigos divididos em seis capítulos e dezenove seções voltados a regulamentação dos procedimentos licitatórios e de contratação administrativa.

Analisando-se exclusivamente as normas relativas ao processo administrativo, identifica-se a existência de apenas um único artigo específico, o art. 109, cuja função é determinar todas as regras processuais para a solicitação do reexame de quaisquer atos administrativos decisórios. Esse artigo está inserido em um capítulo denominado "Recursos Administrativos", que encerra-se nesse único dispositivo normativo. Além desse artigo, é possível verificar outras menções a regras processuais, tendo sido identificado dez referências ao termo "processo administrativo" e catorze alusões ao termo "recurso administrativo". Portanto, é possível a constatação de que a Lei Federal n. 8.666/93 não se preocupa tão profundamente com a regulamentação de procedimentos gerais do processo administrativo, tratando mais detidamente das próprias peculiaridades das licitações e contratações.

Desse modo, para a verificação da efetivação das garantias recursais pela Lei Federal n. 8.666/93, analisar-se-á, primeiramente, o art. 109, para, depois, relacioná-lo com os demais dispositivos normativos que tratem do tema dos recursos administrativos dispersos ao longo do texto normativo.

\subsection{As garantias recursais na Lei Federal n. 8.666/93: tipologia recursal e regras específicas dessa legislação.}

As garantias recursais da Lei Federal n. 8.666/93 se concentram em torno do "Capítulo V - Dos Recursos Administrativos", composto exclusivamente pelo art. 109. Além disso, é possível encontrar algumas remissões a regras contidas nesse dispositivo 
normativo em outros artigos da legislação, a saber: (i) art. 38, VIII; (ii) art. 40, XV; (iii) art. 41, §2º ; e (iv) art. 43, II, cuja análise também é fundamental para a determinação da medida garantista da Lei Federal n. 8.666/93.

\section{a) Recursos administrativos (art. 109 da Lei Federal n. 8.666/93)}

$\mathrm{O}$ art. 109 da Lei Federal n. 8.666/93, que se divide em três incisos e seis parágrafos, apresenta toda a regulamentação da interposição de recursos administrativos em sede de procedimento licitatório. Enquanto cada inciso determina a possibilidade da apresentação de uma espécie recursal, os parágrafos estabelecem regras específicas quanto a intimação dos atos, efeito dos recursos, impugnação por terceiros, encaminhamento e recebimento do requerimento e prazos.

Conforme o dispositivo normativo, no âmbito do procedimento licitatório, é possível a apresentação de (i) pedido de reconsideração (art. 109, III e art. 109, §4º); (ii) representação (art. 109, II); e (iii) recurso administrativo (art. 109, I).

(i) Pedido de reconsideração

O pedido de reconsideração é o requerimento apensado ao recurso administrativo, cuja finalidade é solicitar a retratação da autoridade administrativa decisória em relação a uma decisão por ela proferida, visando à sua invalidação. A reconsideração pode ser feita tanto de ofício - nas situações em que a autoridade administrativa identificar espontaneamente um problema no procedimento licitatório, i.e. de autenticidade em um dos documentos de habilitação do licitante (JUSTEN FILHO, 2010, p. 931) - quanto por provocação do interessado - nas situações em que os legitimados recursais provocarem o reexame da decisão da autoridade.

Haja vista a redação do art. $109, \S^{\circ}$, necessariamente o pedido de reconsideração deve estar apensado ao recurso administrativo. Assim, a autoridade decisória receberá o recurso contendo o pedido de reconsideração, para, no prazo de cinco dias úteis, proceder à reconsideração ou ao encaminhamento do recurso administrativo à autoridade hierarquicamente superior. 
Deve-se notar, contudo, que a reconsideração da decisão pela comissão de licitação não pode impossibilitar o acesso dos legitimados ao juízo recursal da autoridade hierarquicamente superior, pois:

\begin{abstract}
Se outra fosse a orientação, ter-se-ia de abrir faculdade aos interessados interporem recurso contra a reconsideração, que constitui um ato administrativo de cunho decisório. Ter-se-ia de renovar o processamento do recurso, aplicando-se as regras anteriormente enunciadas. Isso, além de uma grande perda de tempo, criaria o risco de a controvérsia eternizar-se (desde que a autoridade sempre reconsiderasse seu ato anterior) (JUSTEN FILHO, 2010, p. 931)
\end{abstract}

Dessa forma, ainda que a autoridade administrativa - representada na figura da comissão de licitação - venha a optar pelo deferimento do pedido de reconsideração, deverá haver obrigatoriamente o encaminhamento do recurso administrativo à autoridade hierarquicamente superior, ainda que o questionamento passe a recair sobre a nova decisão resultado do juízo de reconsideração.

Em relação ao prazo de cinco dias úteis para a apresentação de pedido de reconsideração, o art. 109, $5^{\circ}$ demonstra a preocupação do legislador infraconstitucional em determinar que tanto o início quanto a fluência desse prazo somente poderão correr mediante a possibilidade efetiva de vistas dos autos pelo interessado. Esse dispositivo normativo tem uma função fundamental na realização do devido processo legal administrativo, pois possibilita aos legitimados recursais o alargamento dos meios de defesa e contraditório, permitindo que o interessado tenha acesso a todas as informações necessárias para instruir adequadamente o seu pedido. Sem dúvida alguma, esse dispositivo normativo prestigia um elemento fundamental da defesa, sem o qual seria difícil ou mesmo impossível o exercício do direito de recorrer ${ }^{139}$.

Há uma interessante observação a se fazer a respeito do pedido de reconsideração aqui analisado. Embora o art. 109, III, também estabeleça a possibilidade de apresentação de pedido de reconsideração, diferentemente do art. 109 , $4^{\circ}$, trata exclusivamente do pedido de reconsideração quanto a decisão que determina a aplicação da penalidade de declaração de inidoneidade para licitar ou contratar com a Administração Pública pelo

\footnotetext{
${ }^{139}$ ADMINISTRATIVO. LICITAÇÃO. CONCORRÊNCIA PARA A CONCESSÃO DE SERVIÇOS DE RADIODIFUSÃO E IMAGENS. HABILITAÇÃO. RECURSOS TEMPESTIVOS. REPRESENTAÇÕES APRESENTADAS SEM VISTA DA PARTE CONTRÁRIA. MANDADO DE SEGURANÇA PARCIALMENTE PROCEDENTE. Na interposição de recurso administrativo a Comissão de Licitação deve franquear à parte recorrida vista do processo. Inteligência do art. 109, § $5^{\circ}$, da Lei 8.666/93. Mandado de Segurança parcialmente concedido para declarar nulos os atos posteriores à interposição das Representações. (SUPERIOR TRIBUNAL DE JUSTIÇA. Mandado de Segurança n. 7106 DF 2000/0073932-4, Relator: Ministro Francisco Falcão, j. 27 junho 2001)
} 
Ministro de Estado, do Secretário Estadual ou Municipal. Não há, porém, nenhuma especificidade quanto a essa regra, devendo-se adotar todos os preceitos aplicáveis ao pedido de reconsideração inscrito no art. $109, \S^{\circ}$.

(ii) Recursos administrativos

Observe-se o quadro sinóptico abaixo:

\begin{tabular}{|c|c|}
\hline \multicolumn{2}{|c|}{ Recursos administrativos (art. 109, I) } \\
\hline $\begin{array}{l}\text { Hipóteses de cabimento (art. 109, I, } a \text { - } \\
f \text { ) }\end{array}$ & $\begin{array}{l}\text { 1. Habilitação ou inabilitação do licitante } \\
\text { (art. } 109, \mathrm{I}, a \text { ) } \\
\text { 2. Julgamento das propostas (art. } 109, \mathrm{I}, b \text { ) } \\
\text { 3. Anulação ou revogação da licitação (art. } \\
\text { 109, I, } c \text { ) } \\
\text { 4. Indeferimento do pedido de inscrição } \\
\text { em registro cadastral, sua alteração ou } \\
\text { cancelamento (art. } 109, \mathrm{I}, d \text { ) } \\
\text { 5. Rescisão do contrato, a que se refere o } \\
\text { inciso I do art. } 79 \text { (art. } 109 \text {, I, e) } \\
\text { 6. Aplicação das penas de advertência, } \\
\text { suspensão temporária ou de multa (art. } \\
109, \mathrm{I}, f \text { ). }\end{array}$ \\
\hline Legitimidade recursal & $\begin{array}{l}\text { Licitante (atos praticados no curso da } \\
\text { licitação) } \\
\text { Interessado (antes da apresentação da } \\
\text { documentação ou proposta) } \\
\text { Contratantes (atos contratuais) }\end{array}$ \\
\hline Efeitos & $\begin{array}{l}\text { Suspensivo somente nas hipóteses de } \\
\text { habilitação de licitantes e julgamento de } \\
\text { propostas. }\end{array}$ \\
\hline Prazo & $\begin{array}{l}\text { Interposição: } 05 \text { (cinco) dias úteis } \\
\text { Decisão: } 05 \text { (cinco) dias úteis }\end{array}$ \\
\hline
\end{tabular}

Tabela 09: Recursos administrativos (art. 109, I)

Fonte: elaboração própria a partir da Lei Federal n. 8.666/93

$\mathrm{O}$ art. 109, I, estabelece o cabimento de recurso administrativo nas hipóteses de: (i) habilitação ou inabilitação do licitante (art. 109, I, a); (ii) julgamento das propostas (art. 109, I, b); (iii) anulação ou revogação da licitação (art. 109, I, c); (iv) indeferimento do pedido de inscrição em registro cadastral, sua alteração ou cancelamento (art. 109, I, d); (v) rescisão do contrato, a que se refere o inciso I do art. 79 (art. 109, I, e); (vi) aplicação das penas de advertência, suspensão temporária ou de multa (art. 109, I, f). Ainda que a restrição do cabimento de recursos administrativos às hipóteses apresentadas 
pelas alíneas do art. 109, I, possa caracterizar uma possível violação à garantia constitucional ao direito de recorrer, não é o caso, pois tais hipóteses praticamente abrangem todas as situações em que a autoridade administrativa está emitindo ato administrativo de caráter decisório, ou seja, sobre os quais poderá recair a interposição de recurso administrativo. Além disso, as situações não previstas por esse dispositivo estão cobertas pela representação, conforme se verá mais adiante.

Apesar de não haver nenhuma menção expressa no dispositivo normativo, a legitimidade recursal é primariamente do(s) licitante(s) nas impugnações dos atos praticados durante todo o procedimento licitatório do(s) contratante(s) nas impugnações dos atos de natureza contratual. Apenas nas hipóteses de impugnação das cláusulas editalícias, ou seja, cinco dias úteis antes do encerramento do prazo para a apresentação da documentação ou das propostas é que serão legitimados os interessados não participantes do procedimento licitatório (JUSTEN FILHO, 2010, p. 924).

$\mathrm{O}$ art. $109, \S 2^{\circ}$, determina o efeito suspensivo dos recursos administrativos interpostos contra a habilitação de licitantes e o julgamento de propostas. Dessa forma, somente mediante decisão da autoridade administrativa é que as outras hipóteses desfrutarão o efeito suspensivo da interposição do recurso administrativo, devendo, portanto, operar todos os efeitos da decisão original até o possível desfazimento do ato administrativo decisório original pela decisão recursal.

O prazo para interposição do recurso administrativo é de cinco dias úteis, cuja contagem se inicia a partir da intimação do ato decisório ou da lavratura da ata ${ }^{140}$, que deverá ser feita por meio da imprensa oficial, comunicação pessoal ou ato público ao qual deverão comparecer todos os interessados - presencialmente ou por meio de representação. A contagem do prazo deve ser feita excluindo-se o dia do início e incluindo-se o do vencimento (art. 110).

O prazo para decisão do recurso administrativo também é de cinco dias úteis.

Finalmente, o art. 109, $\S 3^{\circ}$ estabelece o prazo para impugnação do recurso, expressando claramente a preocupação em dar-se ciência da proposição do recurso administrativo aos demais envolvidos. No limite, trata-se de uma regra extremamente importante para a ampliação dos meios de defesa, por permitir aos demais licitantes que

140 ،“'A lavratura da ata’ significa a realização de sessão pública destinada à divulgação de uma decisão. A ata será o instrumento de documentação desse ato público. Se houver vício na realização da sessão pública, o prazo não iniciará seu curso. Assim, a lavratura da ata não provocará efeito em relação aos interessados que não forem regularmente convocados a comparecer à sessão" (JUSTEN FILHO, 2010, pp. 925-926) 
se manifestem acerca da questão trazida por terceiros, possibilitando, assim, sua defesa nas situações que igualmente possam afetar sua órbita jurídica no âmbito da licitação ${ }^{141}$.

(iii) Representação

Embora a $\mathrm{CF} / 88$ tenha assegurado irrestritamente o direito de recorrer a todos os litigantes e interessados participantes de quaisquer processos administrativos (art. $5^{\circ}, \mathrm{LV}$ $\mathrm{CF} / 88$ ), não constitui uma violação ao texto constitucional a regulamentação infraconstitucional desse direito, determinando, caso a caso, quais os legitimados recursais, bem como as hipóteses em que os recursos devem ser permitidos.

A redação levemente truncada do art. 109, II, pode, à primeira vista, fazer parecer que o legislador infraconstitucional tinha o objetivo de estabelecer uma limitação ao direito de recorrer, assim, seria possível interpretar que ao determinar que haveria decisões relacionadas "com o objeto da licitação ou do contrato não cabe recurso hierárquico", a orientação normativa era pelo cerceamento do direito de recorrer em determinadas hipóteses. Ora, a questão não é propriamente a existência de decisões irrecorríveis, mas o instrumento a ser utilizado para se solicitar o reexame dessas decisões $^{142}$.

141 Apenas à título exemplificativo, transcreve-se uma dessas comunicações:

Publicado por: Sonia Maria Caldeira

Código Identificador: CBAC6C87

\author{
COMISSÃO DE LICITAÇÃO \\ COMUNICADO DE RECURSO LICITAÇÃO \\ CONCORRÊNCIA No 01/15 \\ Processo Licitatório n. ${ }^{\circ}$ 004/15 \\ Concorrência n. ${ }^{\circ} 01 / 15$
}

Conforme o disposto no $\underline{\S 3^{\circ}}$ do art. 109 da Lei $\underline{8666 / 93}$, comunicamos que a empresa Horizontes Empreendimentos Ltda. interpôs recurso quanto à decisão da Comissão Permanente de Licitação que a inabilitou na licitação Concorrência n. ${ }^{\circ}$ 01/15, Processo $n .^{\circ} 004 / 15$ que tem por objeto a escolha de empresa para a execução das obras de construção de um Imóvel Público, na rua Joaquim Aleixo, n. ${ }^{\circ}$ 140, Centro, em Santa Bárbara.

Os autos do processo encontram-se com vista franqueada aos interessados.

Santa Bárbara, 24 de fevereiro de 2015.

COMISSÃO PERMANENTE DE LICITAÇÃO

${ }^{142}$ Em regra, todas as decisões são passíveis de questionamento por recurso administrativo, salvo nos casos de preclusão do direito de recorrer por razões (i) temporais, (ii) consumativas ou (iii) lógicas ou em função da autoridade administrativa que proferiu a decisão original situar-se no último grau hierárquico daquele ente público (JUSTEN FILHO, 2010, p. 923) 
Conforme explicado anteriormente, no âmbito dos procedimentos licitatórios, somente as hipóteses listadas nas alíneas ( $a-f)$ do inciso I do art. 109 são passíveis de questionamento por meio de interposição de recurso administrativo. Dessa forma, todos os atos administrativos sem caráter propriamente decisório, mas que venham a causar quaisquer tipos de prejuízo ao licitante - ou ao interessado que não esteja constituído como licitante -, poderão ser questionados por meio de representação. Além disso, a representação tem uma função muito importante, pois constitui-se como o instrumento processual para o questionamento das decisões por todos aqueles que não sejam "titulares do direito subjetivo ou interesse pessoal diretamente afetado pela decisão" (JUSTEN FILHO, 2010, p. 923), ou seja, por aqueles que não estejam listados dentre os legitimados recursais pela Lei Federal n. 8.666/93 ${ }^{143}$.

O prazo para a representação é de cinco dias úteis contados a partir da intimação da decisão.

\section{b) Demais dispositivos normativos em que há a referência ao termo "recurso administrativo"}

Nos demais artigos da Lei Federal n. 8.666/93, apenas quatro dispositivos normativos fazem expressamente referência aos recursos administrativos, regulamentando algumas especificidades relacionadas a determinada fase do procedimento licitatório. Em se tratando de regras práticas para o desenvolvimento do direito de recorrer, faz-se necessária a análise mais detalhada desses artigos. Veja a seguir:

(i) art. 38, VIII: Apresenta as regras de armazenamento das peças documentais produzidas em decorrência da interposição de recurso administrativo, representação ou pedido de reconsideração. Conforme esse dispositivo normativo, as peças documentais devem ser incorporadas aos autos, ou seja, independentemente de sua natureza, os documentos devem obrigatoriamente são juntados ao processo administrativo.

\footnotetext{
${ }^{143}$ Desse modo, embora um interessado que não tenha participado da licitação não possa ser considerado titular do direito subjetivo para interposição de recurso administrativo contra habilitação de licitantes, poderá insurgir-se contra esse procedimento por meio da representação (JUSTEN FILHO, 2010, p. 923)
} 
(ii) art. 40, XV: Determina a obrigatoriedade do edital apresentar as normas e instruções para a interposição de recurso administrativo no âmbito de determinado procedimento licitatório. Deve-se salientar que é vedado ao edital o estabelecimento de cláusulas que limitem ou impossibilitem a apresentação de recurso, ainda que de maneira indireta.

(iii) art. 41: $\quad$ Estabelece as regras para a impugnação do edital pelos interessados.

(iv) art. 43, II e III: Reforçam o efeito suspensivo dos recursos administrativos nas hipóteses de questionamento da habilitação do(s) licitante(s) e questionamento do julgamento das propostas.

Conforme afirmado anteriormente, esses artigos consistem em complementações à regulamentação estabelecida pelo art. 109 da Lei Federal n. 8.666/93, isto é, tratam-se de regras ou orientações com a finalidade de reforçar ou ampliar as determinações apresentadas no respectivo capítulo sobre os recursos administrativos no âmbito da lei federal de licitações e contratos administrativos.

\subsection{Considerações acerca da Lei de Licitações e Contratos Administrativos}

A Lei Federal n. 8.666/93 foi publicada seis anos antes da publicação da Lei Federal n. 9.784/99. Além disso, a Lei de Licitações e Contratos Administrativos e a Lei de Processo Administrativo Federal não possuem o objeto de regular o mesmo objeto. Em tese, essas leis não se comunicam diretamente. Entretanto, não se pode deixar de considerar a licitação como uma espécie de processo administrativo, de modo que há de se assegurar o devido processo legal administrativo, com as garantias de ampla defesa e contraditório, e a obrigatória observância dos princípios administrativos no desenvolvimento do processo licitatório desde a publicação do edital até a contratação do licitante cuja proposta foi a escolhida.

A Lei Federal n. 8.666/93 não demonstra uma significativa preocupação com o estabelecimento de regras garantistas de processo administrativo, especialmente em relação à interposição de recursos administrativos. Pergunta-se: seria essa ausência de normas processuais algo prejudicial à efetivação do devido processo legal administrativo nas licitações? Considere-se a redação do art. 40, XV: 


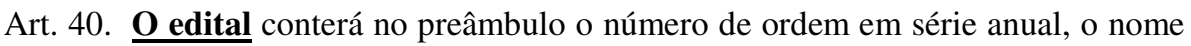
da repartição interessada e de seu setor, a modalidade, o regime de execução e o tipo da licitação, a menção de que será regida por esta Lei, o local, dia e hora para recebimento da documentação e proposta, bem como para início da abertura dos envelopes, e indicará, obrigatoriamente, o seguinte:

XV - instrucões e normas para os recursos previstos nesta Lei; (grifo)

Conforme explicado anteriormente, a existência de norma reguladora ao direito de recorrer - manifestação do direito de petição (art. 5, XXXIV CF/88) - não deve ser interpretada como uma limitação ou violação dessa garantia fundamental. Com efeito, a norma reguladora tem a função primordialmente de instrumentalizar esse direito, adequando sua aplicação a realidade fática.

$\mathrm{O}$ art. 109 da Lei Federal n. 8.666/93 é a norma reguladora do direito de recorrer no âmbito das licitações e contratações administrativas. Entretanto, quando o art. 40, XV determina que "[o] edital [...] indicará, obrigatoriamente, [...] instruções e normas para os recursos previstos", o legislador infraconstitucional está delegando a competência para regular o direito de recorrer diretamente ao agente público responsável pela elaboração do edital de licitação.

Tome-se como exemplo um ente público de natureza educacional - i.e. faculdade de determinada universidade pública - que deseje instalar rede de internet wi-fi antes do início do ano letivo. Tendo em vista a necessidade premente, poderia o agente público estabelecer que, em nome da celeridade processual, o prazo recursal seria menor e a única espécie recursal permitida seria o pedido de reconsideração, evitando-se assim que houvesse a necessidade de análise por parte da autoridade administrativa superior?

Certamente essa cláusula editalícia seria objeto de impugnação ao edital, pois:

Nenhuma regra constante do edital poderá dificultar o exercício do direito de petição assegurado na Lei. Serão inválidas cláusulas editalícias que proíbam recursos ou excluam direito a impugnação a atos da Administração. A invalidade atinge tanto as vedações diretas quanto aquelas indiretas (que subordinam o direito do particular ao cumprimento das formalidades injustificáveis) (JUSTEN FILHO, 2010, 561)

Questiona-se, assim, a utilidade prática desse dispositivo normativo, tendo em vista que nas hipóteses de cláusulas editalícias restritivas ao direito de recorrer, sempre haverá a possibilidade de impugnação do edital, haja vista que não poderiam prevalecer normas reguladoras que limitem ou impossibilitem o direito de recorrer do licitante. Poder-se-ia justificar a existência do art. 40, XV como uma possibilidade de se estabelecer 
uma ampliação ao direito de recorrer, contudo, a existência da Lei Federal n. 9.784/99 eventualmente supriria a necessidade de previsões nesse sentido.

Retomando o questionamento, a aplicação exclusivamente da Lei Federal n. 8.666/93 poderá, eventualmente, significar uma diminuição na realização do devido processo legal administrativo, por meio do cerceamento dos meios de defesa e contraditório em razão da instrumentalização dos recursos administrativos conforme disciplinado por essa legislação federal. Portanto, respeitando-se as peculiaridades estabelecidas pela Lei Federal n. 8.666/93, os atos e procedimentos praticados pelo agente público no âmbito da licitação devem necessariamente estar em conformidade com os princípios e regras processuais da Lei Federal n. 9.784/99 para se alcançar as finalidades constitucionais do processo administrativo. Não se trata apenas de uma questão de subsidiariedade das normas gerais da Lei de Processo Administrativo Federal, para além disso, a aplicação das normas da Lei Federal n. 9.784/99 significa o reconhecimento da inafastabilidade dos direitos e garantias fundamentais no desempenho da função administrativa nas atividades cotidianas da Administração Pública.

\section{Legislações infraconstitucionais básicas das agências reguladoras federais}

Embora não designadas de agências reguladoras, havia no Brasil, desde o início do século XX, entidades com funções regulatórias e fiscalizatórias do setor econômico. O Comissariado de Alimentação Pública (1918), o Instituto de Defesa Permanente do Café (1923), o Instituto do Açúcar e do Álcool (1933), o Instituto Nacional do Mate (1938), o Instituto Nacional do Pinho (1941) e o Instituto Nacional do Sal (1940) possuíam natureza jurídica de autarquia econômica, cuja finalidade era a regulação da produção e do comércio de alimentação pública, café, açúcar e álcool, mate, pinho e sal, respectivamente. Além dessas autarquias, também podem ser citados outros órgãos com funções normativas e fiscalizatórias, como o Banco Central, o Conselho Monetário Nacional, a Comissão de Valores Mobiliários e o CADE (DI PIETRO, 2011, p. 479). Entretanto, o fenômeno de agencificação brasileiro somente se intensificou a partir da década de 1990, paralelamente ao processo global de reforma administrativa (NUNES, et al., 2007, p. 33).

Em razão do contexto de estagnação econômica e a profunda crise físcal iniciada na década de 80 , diversos países buscaram instalar mudanças no sentido da (i) redução da intervenção estatal na economia, (ii) liberalização dos mercados por meio das 
privatizações e (iii) redefinição das funções estatais (PEREIRA, 1995). No Brasil, o modelo implementado foi o da administração pública gerencial, cujos pilares eram: (i) privatização dos ativos públicos, (ii) publicização dos órgãos estatais em entidades públicas não-estatais de direito privado e sem fins lucrativos; (iii) manutenção no poder executivo de apenas funcionários públicos diretamente ligados com o estabelecimento de políticas públicas, (iv) contratação de terceiros; (v) desburocratização por meio da modernização e utilização de tecnologia da informação, (vi) descentralização dos processos decisórios internos e (vii) estabelecimento do princípio da accountability (PIMENTA, 1999, pp. 179-180). Essas mudanças se materializaram por meio do Plano Diretor da Reforma do Aparelho do Estado ${ }^{144}$ e do Plano Nacional de Desestatização ${ }^{145}$.

A criação das agências reguladoras brasileiras aconteceu majoritariamente durante o período dos dois mandatos presidenciais (1995-2002) de Fernando Henrique Cardoso, em ordem cronológica: Agência Nacional de Energia Elétrica (ANEEL) ${ }^{146}$, Agência Nacional do Petróleo (ANP) ${ }^{147}$, Agência Nacional de Telecomunicações (ANATEL) ${ }^{148}$, Agência Nacional de Vigilância Sanitária (ANVISA) ${ }^{149}$, Agência Nacional de Saúde Suplementar (ANS) ${ }^{150}$, Agência Nacional das Águas (ANA) ${ }^{151}$, Agência Nacional de Transportes Aquaviários e Agência Nacional de Transportes Terrestres (ANTAQ e ANTT) ${ }^{152}$, Agência Nacional do Cinema (ANCINE) ${ }^{153}$ e Agência

\footnotetext{
${ }^{144}$ Disponível em <http://www.bresserpereira.org.br/documents/mare/planodiretor/planodiretor.pdf>. Acesso em 06 mar 2015.

${ }^{145}$ Instituído por meio da Lei n. 8.031, de 12 de abril de 1990, posteriormente alterada pela Lei n. 9.491, de 9 de setembro de 1997.

146 BRASIL. Lei Federal n. 9.427/96, de 26 de dezembro de 1996. Disponível em < http://www.planalto.gov.br/ccivil_03/leis/19427cons.htm>. Acesso em 06 mar 2015.

147 BRASIL. Lei Federal n. 9.478/97, de 06 de agosto de 1997. Disponível em < http://www.planalto.gov.br/ccivil_03/leis/19478.htm>. Acesso em 06 mar 2015.

148 BRASIL. Lei Federal n. 9.472/97, de 16 de julho de 1997. Disponível em < http://www.planalto.gov.br/ccivil_03/leis/19472.htm>. Acesso em 06 mar 2015.

149 BRASIL. Lei Federal n. 9.782/99, de 26 de janeiro de 1999. Disponível em < http://www.planalto.gov.br/ccivil_03/leis/19782.htm>. Acesso em 06 mar 2015.

150 BRASIL. Lei Federal n. 9.961/00, de 28 de janeiro de 2000. Disponível em < http://www.planalto.gov.br/ccivil_03/leis/19961.htm>. Acesso em 06 mar 2015.

151 BRASIL Lei Federal n. 9.984/00, de 17 de julho de 2000. Disponível em < http://www.planalto.gov.br/ccivil_03/leis/19984.htm>. Acesso em 06 mar 2015.

152 BRASIL. Lei Federal n. 10.233/01, de 5 de junho de 2001. Disponível em < http://www.planalto.gov.br/ccivil_03/leis/leis_2001/110233.htm>. Acesso em 06 mar 2015.

153 BRASIL. Medida Provisória n. 2.228-1/01, de 6 de setembro de 2001. Disponível em < http://www.planalto.gov.br/ccivil_03/mpv/2228-1.htm>. Acesso em 06 mar 2015.
} 
Nacional de Aviação Civil (ANAC) ${ }^{154}$. Atualmente, o quadro de entidades públicas brasileiras é composto por dez agências reguladoras ${ }^{155}$, conforme a tabela a seguir:

\begin{tabular}{|c|c|c|c|}
\hline Diploms inctituldor & Agbinola & Miceso & Looo \\
\hline $\begin{array}{l}\text { Lefi no } 9.427 \text { de } \\
26 / 12 / 1996\end{array}$ & $\begin{array}{l}\text { Agoncla Nacionsl } \\
\text { de Energla } \\
\text { Elevica }\end{array}$ & 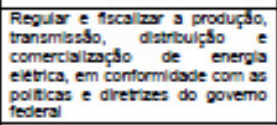 & NEEL \\
\hline $\begin{array}{l}\text { Lel no } 9.472 \text { de } \\
16107 / 1997\end{array}$ & $\begin{array}{l}\text { Agbincia Nacional } \\
\text { de } \\
\text { Telecomunicaçbes }\end{array}$ & $\begin{array}{l}\text { Regular efrcalizar os renvigos de } \\
\text { tetecomunicaphes do pala }\end{array}$ & - $A N$ \\
\hline $\begin{array}{l}\text { Lel no } 9.478 \text { de } \\
26 / 12 / 1997\end{array}$ & $\begin{array}{l}\text { Aobncla Nacional } \\
\text { do Perrileo }\end{array}$ & 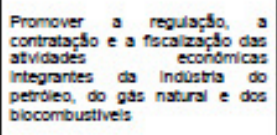 & \\
\hline $\begin{array}{l}\text { Lef no } 9.782 \text { de } \\
26101 / 1999\end{array}$ & $\begin{array}{l}\text { Agoncia Nacionsl } \\
\text { de Volincla } \\
\text { Santaria }\end{array}$ & $\begin{array}{l}\text { Proteger e promover a savde, } \\
\text { gsronthoso a segurshça saniaris } \\
\text { de produtos e serviçoa }\end{array}$ & ate \\
\hline $\begin{array}{l}\text { Lel ne } 9.961 \text { de } \\
28101 / 20000\end{array}$ & $\begin{array}{l}\text { Agbincia Nacionsl } \\
\text { de sadoe } \\
\text { Supiementar }\end{array}$ & 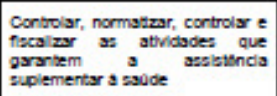 & Thes \\
\hline $\begin{array}{l}\text { Lel n n } 9.984 \text { de } \\
17 / 07 / 2000\end{array}$ & $\begin{array}{l}\text { Aobncis Nacional } \\
\text { de Aewas }\end{array}$ & 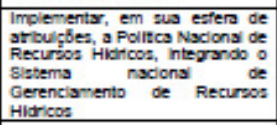 & towns \\
\hline $\begin{array}{l}\text { Lel no } 10.233 \text { de } \\
\text { Os:06/2001 }\end{array}$ & $\begin{array}{l}\text { Agoncla Nacionsl } \\
\text { de Transportes } \\
\text { Temeatres }\end{array}$ & 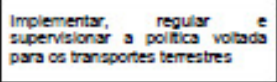 & \\
\hline $\begin{array}{l}\text { Lel no } 10.233 \text { de } \\
\text { O5/06/2001 }\end{array}$ & $\begin{array}{l}\text { Aodncis Nacional } \\
\text { de Transportes } \\
\text { Aquavilarios }\end{array}$ & 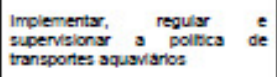 & \\
\hline $\begin{array}{l}\text { Medida Provisoria n }{ }^{\circ} \\
2.228 \text { de } 06 / 09 / 2001\end{array}$ & $\begin{array}{l}\text { Aotincis Nacionsal } \\
\text { do Cinema }\end{array}$ & $\begin{array}{l}\text { Fomentar, reguls e facalizar as } \\
\text { industrias cinemalograncas e } \\
\text { videofonografles }\end{array}$ & 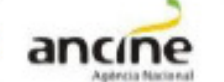 \\
\hline $\begin{array}{l}\text { Lel in } 11.182 \text { de } \\
27 / 09 / 2005\end{array}$ & $\begin{array}{l}\text { Aodncla Nacionsal } \\
\text { de Auraçso Clivt }\end{array}$ & 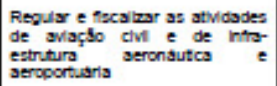 & \\
\hline
\end{tabular}

Tabela 10: Agências reguladoras brasileiras Fonte: (DIAS, L. N., 2010, p.22)

Conforme demonstrado pela tabela, as agências reguladoras foram instituídas por leis federais ${ }^{156}$, que além de estabelecerem a missão institucional de cada agência, também dispõem sobre suas competências, atribuições e funções na organização administrativa. Nesse sentido, as leis instituidoras desempenham elementar papel na consolidação dos princípios e normas estruturantes das atividades das agências reguladoras, designando desde a concepção do quadro funcional até as diretrizes para o

154 BRASIL. Lei Federal n. 11.182/05, de 27 de setembro de 1996. Disponível em < http://www.planalto.gov.br/ccivil_03/_ato2004-2006/2005/Lei/L11182.htm>. Acesso em 06 mar 2015.

155 Tramita no Congresso Nacional, o Projeto de Lei n. 5.807, de 19 de junho de 2013, que dispõe sobre a atividade de mineração e cria o Conselho Nacional de Política Mineral e a Agência Nacional de Mineração (ANM). O inteiro teor desse projeto pode ser encontrado na página da Câmara dos Deputados (Disponível em <http://www.camara.gov.br/proposicoesWeb/fichadetramitacao?idProposicao=581696>. Acesso em 05 mar 2015.

${ }^{156}$ Salvo exceção representada pela ANCINE, cuja instituição se deu por meio de medida provisória. 
ordenamento da atividade reguladora em si. Além disso, as leis instituidoras consistem no diploma normativo básico para se fixar as regras processuais desses entes públicos.

Portanto, considerando a importância das agências reguladoras para a organização administrativa federal, assim como a constatação de que esses entes públicos desempenham função administrativa por meio de processo administrativo, não poderia deixar de constar o diagnóstico das garantias recursais nas legislações infraconstitucionais básicas das agências reguladoras. Assim, em razão dessa sistematização ser desenvolvida a partir do paradigma recursal estabelecido pela Lei Federal n. 9.784/99, o exame dessas leis divide-se em dois blocos organizados a partir do ano de publicação desse paradigma normativo adotado, ou seja: (i) agências reguladoras instituídas previamente a Lei Federal n. 9.784/99 e (ii) agências instituídas posteriormente a Lei Federal n. 9.784/99.

\subsection{Agências reguladoras instituídas previamente a Lei Federal n. 9.784/99}

Antes da edição da Lei Federal n. 9.784/99, foram criadas por instrumento próprio, quatro agências reguladoras: (i) a Agência Nacional de Energia Elétrica (ANEEL), (ii) a Agência Nacional de Telecomunicações (ANATEL), (iii) a Agência Nacional do Petróleo (ANP) e (iv) a Agência Nacional de Vigilância Sanitária (ANVISA).

Tendo em vista que, por razões cronológicas, nenhuma das legislações dessas agências reguladoras sofreu direta ou indiretamente influência das normas gerais de processo administrativo estabelecidas pela Lei Federal n. 9.784/99, pode-se afirmar que o principal instrumento normativo que serviu como base para a introdução de normas processuais nessas legislações infraconstitucionais foi a $\mathrm{CF} / 88$. Assim, ainda que não houvesse uma regulamentação específica para o processo administrativo, princípios fundamentais como o devido processo legal administrativo com as garantias de ampla defesa e contraditório (art. 5, LV CF/88), bem como os demais princípios administrativos (art. 37, caput $\mathrm{CF} / 88$ ) já eram de observância obrigatória para a elaboração de quaisquer legislações infraconstitucionais que, também, tivessem o objetivo de estabelecer normas processuais para a realização de suas tarefas relacionadas com o desempenho da função administrativa.

Ainda que as legislações infraconstitucionais básicas não disciplinem profundamente questões referentes ao processo administrativo - especialmente em relação aos recursos administrativos - necessariamente deveria ter havido uma preocupação do legislador infraconstitucional em promover a ampliação dos instrumentos 
necessários para a efetivação do direito de petição e do direito de recorrer, bem como das garantias fundamentais necessárias para a realização desses dois direitos. Levando-se em consideração exclusivamente as regras recursais presentes nas legislações infraconstitucionais básicas das agências reguladoras criadas anteriormente à Lei Federal n. 9.784/99, observe-se o quadro esquemático a seguir, contendo os dispositivos normativos cujo conteúdo faça referência aos recursos administrativos no contexto dos procedimentos realizados por essas agências.

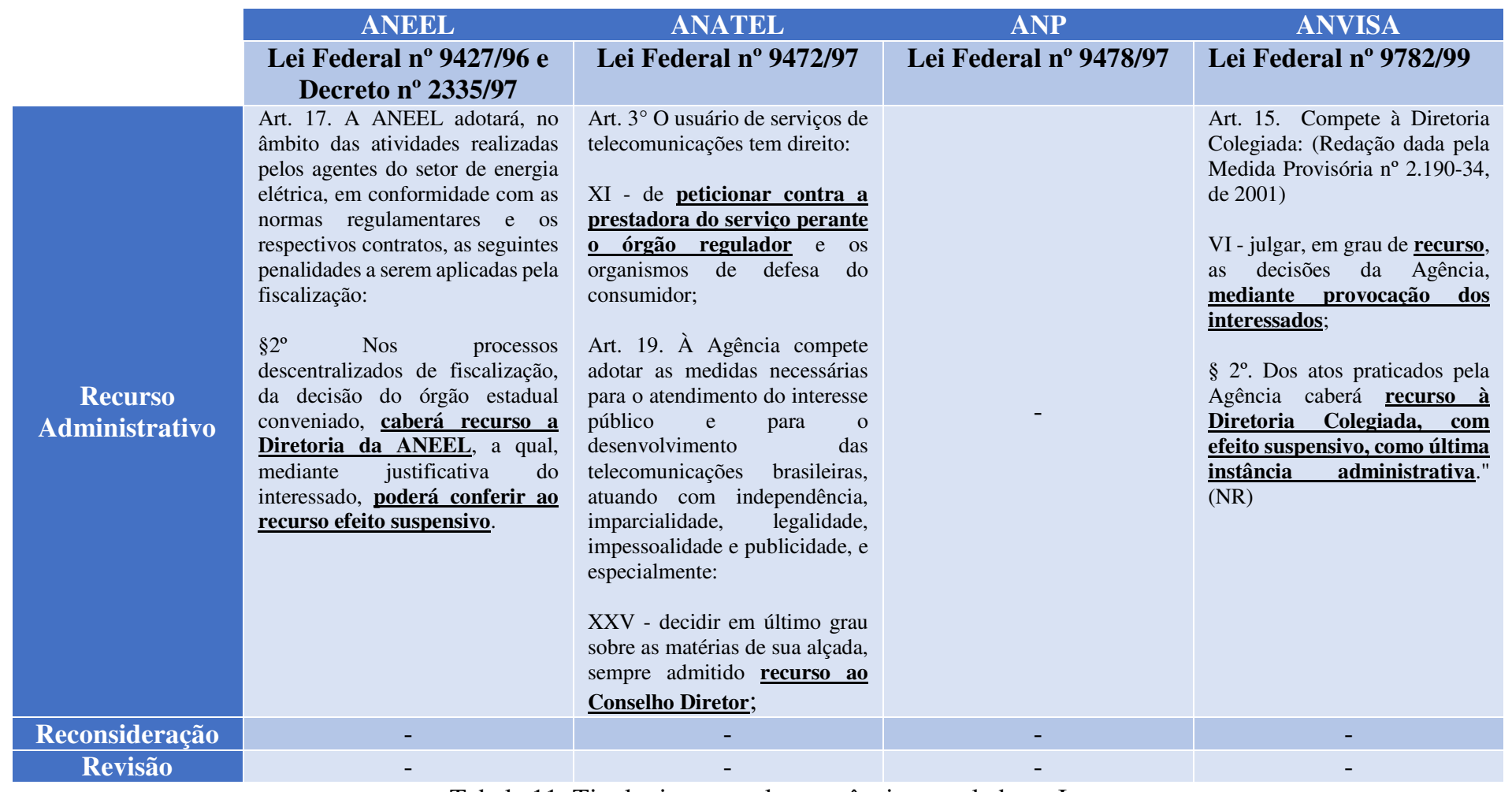

Tabela 11: Tipologia recursal nas agências reguladoras I

Fonte: elaboração própria a partir das Lei Federal n. 9.427/96, Decreto n. 2.335/97, Lei Federal n.

9.472/97, Lei Federal n. 9.478/97 e Lei Federal n. 9.782/99

Previamente ao exame específico de cada agência reguladora instituída anteriormente à Lei Federal n. 9.874/99, destaca-se uma constatação relevante: conforme é possível se verificar por meio do quadro esquemático, não há qualquer previsão normativa para a apresentação de pedido de reconsideração ou a interposição de revisão administrativa nas legislações da ANEEL, ANATEL, ANP, ANVISA, o que faria supor que o único meio existente para o questionamento das decisões administrativas seria o recurso administrativo.

Pondera-se: a ausência de previsão normativa expressa da reconsideração e da revisão administrativa pressupõe necessariamente a impossibilidade do interessado 
apresentar pedido de reconsideração ou pedido de revisão no âmbito dessas agências reguladoras? Não, pois conforme explicado no capítulo dois, o recebimento, processamento e julgamento desses pedidos constituem dever inafastável da autoridade administrativa em decorrência do direito de petição (art. 5. ${ }^{\circ}$, XXXIV, "a" da CF/88). Portanto, ainda que não expressamente previstos, o pedido de reconsideração e a revisão administrativa configuram direito dos cidadãos atendidos pelos serviços regulados por essas agências ${ }^{157}$.

\section{a) ANEEL (Lei Federal n. 9.427/96 e Decreto n. 2.335/97)}

Analisando-se a Lei Federal n. 9.427/96, responsável pela criação da ANEEL, não foi encontrada nenhuma norma processual de caráter recursal, motivo pelo qual optou-se pela verificação de normas processuais no Decreto n. 2.335/97, diploma normativo constituidor da ANEEL, constatando-se a existência de somente um artigo relacionado aos recursos administrativos.

$\mathrm{O}$ art. $17, \S 2^{\circ}$ do Decreto n. $2.335 / 97$ assegura o cabimento de recurso administrativo contra decisões dos órgãos estaduais conveniados ${ }^{158}$ ocorridas em sede de processos descentralizados de fiscalização, estabelecendo a competência da diretoria da agência reguladora para seu processamento e julgamento e a possibilidade da atribuição de efeito suspensivo mediante apresentação de motivo justificado.

O significado dessa garantia recursal está intimamente relacionado com a descentralização das atividades da ANEEL, por meio da constituição de convênios com agências estaduais de regulação de serviços públicos.

\footnotetext{
${ }^{157}$ No item 3.3 desse capítulo é esclarecido ao leitor que não é desconhecida dessa pesquisa a existência de atos administrativos (resoluções, portarias, deliberações, etc.) específicos, no seio de cada uma das agências, com a finalidade do estabelecimento das regras de processo administrativo, em que, certamente, pode-se encontrar previstos o pedido de reconsideração e a revisão administrativa.

158 "Na sua função de regular o funcionamento do setor elétrico brasileiro, a ANEEL tem como missão 'proporcionar condições favoráveis para que o mercado de energia elétrica se desenvolva com equilíbrio entre os agentes e em benefício da sociedade'.

Para cumprimento pleno dessa missão, considerando a dimensão e a extensão do território nacional e do sistema elétrico brasileiro, a ANEEL, valendo-se de prerrogativa que lhe foi conferida por lei, tomou a decisão estratégica de descentralizar suas atividades às Unidades da Federação, por meio do estabelecimento de parcerias com as Agências Estaduais de Regulação de Serviços Públicos.

Com essa estratégia, além de criar condições para um relacionamento sólido com os estados e o Distrito Federal, a ANEEL vem tornando mais ágil e presente a sua atuação nas unidades da Federação, aproximando-se da sociedade e facilitando a vida dos consumidores e dos agentes regulados.

Nesse contexto, a descentralização torna-se um dos principais mecanismos que aproxima a ANEEL da sociedade" (AGÊNCIA NACIONAL DE ENERGIA ELÉTRICA, 2005, p. 9)
} 
A instalação de uma agência local de regulação teria como finalidade, segundo a ANEEL, a diminuição da assimetria de informações entre os consumidores e os agentes regulados, possibilitando, assim, maior efetividade na resolução das demandas consumeristas (AGÊNCIA NACIONAL DE ENERGIA ELÉTRICA, 2005, pp. 15-16). Entretanto, para a investidura desses órgãos estaduais conveniados na função reguladora, foi imprescindível que a ANEEL lhes conferisse as competências decisórias necessárias para a resolução dos conflitos entre consumidores e agentes regulados.

Considerando-se que o exercício dessas competências decisórias pelos agentes reguladores locais obrigatoriamente deve estar orientado pelos princípios e normas processuais constitucionalmente previstas, quaisquer decisões administrativas em desconformidade com tais regras ensejarão controle administrativo por parte da ANEEL $^{159}$. Nesse sentido, o art. $17, \S 2^{\circ}$ do Decreto n. $2.335 / 97$ possui o objetivo de instrumentalizar esse controle administrativo das decisões concebidas no âmbito de delegação de competências decisórias da ANEEL aos órgãos estaduais conveniados.

\section{b) ANATEL (Lei Federal n. 9.472/97)}

As telecomunicações exercem uma função fundamental na sociedade da informação, desempenhando relevantes atribuições no cotidiano das empresas e dos cidadãos $^{160}$. Em razão dessa importância do setor de telecomunicações para a ordem pública brasileira, a instituição de um órgão regulador dos serviços de telecomunicações esteve, desde logo, constitucionalmente assegurada (art. 21, XI CF/88).

Assim, o art. $8^{\circ}$ da Lei Geral de Telecomunicações (Lei Federal n. 9.472/97) determinou a criação da Agência Nacional de Telecomunicações, ente público federal, submetido ao regime autárquico especial e vinculado ao Ministério das Comunicações, cuja função é a de órgão regulador das telecomunicações.

Não é por outro motivo que os desafios regulatórios enfrentados pela ANATEL são bastante consideráveis, como exemplificado a seguir: “ [o] Brasil registrou, em

\footnotetext{
159“'As concessionárias, permissionárias e autorizadas, a seu juízo, poderão recorrer das decisões da Agência Reguladora Estadual, delegada da ANEEL" (AGÊNCIA NACIONAL DE ENERGIA ELÉTRICA, 2005, p. 17)

160 “Constituem Serviços de Telecomunicações a transmissão, emissão ou recepção de símbolos, caracteres, sinais, escritos, imagens, sons ou informações de qualquer natureza, por fio, rádio, eletricidade, meios ópticos ou qualquer outro processo eletromagnético. A prestação dos Serviços de Telecomunicações é feita por agentes que detenham concessão, permissão ou autorização para a prestação do serviço" (TELEBRASIL, 2014, p. 5)
} 
janeiro de 2015, 281,70 milhões de linhas ativas na telefonia móvel e teledensidade de 138,34 acessos por 100 habitantes (ANATEL, 2015).

Portanto, a previsão de normas processuais asseguradoras do devido processo legal administrativo com as garantias do contraditório e da ampla defesa, bem como normas instrumentalizadoras do direito de petição e do direito de recorrer são fundamentais para o exercício da função reguladora por parte da ANATEL.

Na Lei Federal n. 9.472/97 foram identificados somente dois dispositivos normativos relacionados com as garantias recursais. $\mathrm{O}$ art. $3^{\circ}$, XI da Lei Federal $\mathrm{n}$. 9.472/97 assegura a todos os usuários de telecomunicações o direito de peticionar contra a prestadora de serviços perante a ANATEL, reforçando o direito fundamental previsto no art. 5 $5^{\circ}$ XXXIV CF/88. O art. 19, XXV da Lei Federal n. 9.472/97 dispõe sobre a possibilidade de apresentação de recurso administrativo, em último grau, ao conselho diretor contra decisões proferidas pela própria ANATEL, ou seja, apresenta a última instância do recurso hierárquico.

$\mathrm{O}$ art. $3^{\circ}$, XI da Lei Federal n. 9.472/97 possui uma função mais integradora entre o consumidor e a agência reguladora, garantindo ao consumidor que se sentir lesado quanto a prestação de serviços pelos agentes regulados a possibilidade de peticionamento ao órgão regulador. Interessante notar que, na realidade prática, a ANATEL viabiliza esse direito de petição por meio de uma Central de Atendimento Telefônico (1331), onde consumidor poderá registrar reclamações contra as operadoras de serviços quando considerar que elas não estejam cumprindo suas obrigações ${ }^{161}$.

Por sua vez, art. 19, XXV da Lei Federal n. 9.472/97 está mais relacionado aos processos administrativos em que figurem como parte o agente regulado, pois prevê o

161 “O que a Anatel faz com as reclamações recebidas contra as operadoras

A Anatel facilita e auxilia a interação com as operadoras de serviços de telecomunicações. E faz isso exigindo que as empresas respondam, com qualidade e em até cinco dias úteis, as reclamações que você registrou.

A Anatel monitora a quantidade e o motivo das reclamações contra cada operadora, o tempo que elas levam para responder e a qualidade das respostas para cobrar delas um nível de atendimento cada vez melhor. Entre outros pontos, a sua reclamação, somada às reclamações dos outros consumidores, nos ajuda a:

1) Calcular e divulgar o Ranking das Operadoras (Índice de Desempenho no Atendimento - conheça o índice), que possibilita à sociedade conhecer e comparar as empresas que melhor atendem às demandas do consumidor;

2) Identificar os principais problemas das operadoras e atuar de forma preventiva ou mesmo aprimorar as regras existentes;

3) Realizar, quando necessário, ações de fiscalização e de acompanhamento e controle, que podem resultar em multas contra as operadoras, medidas cautelares ou celebrações de termos de ajustamento de conduta" (ANATEL, 2015) 
cabimento de recursos administrativos contra decisões "sobre matérias de sua alçada", ou seja, mais diretamente relacionadas as atividades regulatórias.

\section{c) ANP (Lei Federal n. 9.478/97)}

Conforme esclarece o seu folder institucional, a Agência Nacional do Petróleo (ANP) possui as seguintes finalidades:

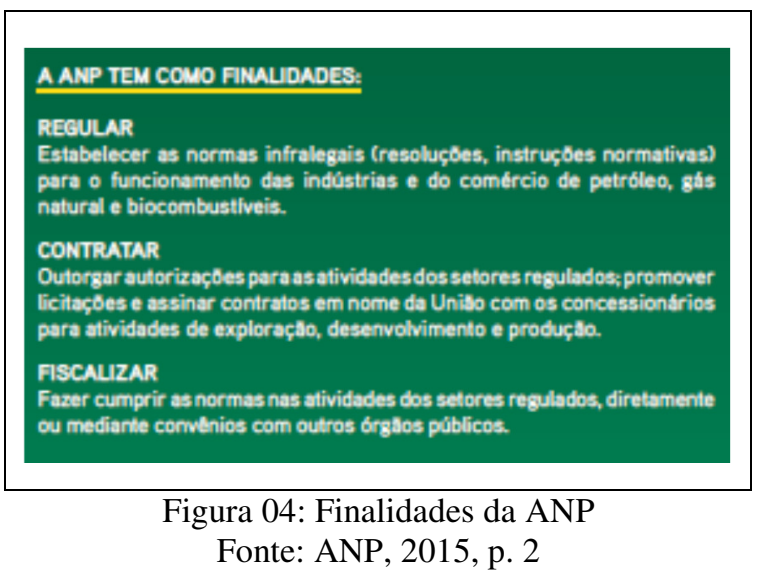

A análise da Lei Federal n. 9.478/97, legislação instituidora da ANP, demonstra que o legislador infraconstitucional não se preocupou diretamente com a regulamentação das normas processuais administrativas, pois não há sequer uma menção às regras componentes do sistema recursal para essa agência reguladora federal. Em outras palavras, não há referência a recursos administrativos, pedido de reconsideração ou revisão administrativa nas legislações básicas da ANP.

\section{d) ANVISA (Lei Federal n. 9.782/99)}

A Agência Nacional de Vigilância Sanitária (ANVISA), instituída pela Lei Federal n. 9.782/99, tem como escopo a regulação e fiscalização de todos os setores da economia vinculados à produtos e serviços que possam causar prejuízo a saúde da população brasileira.

Por meio do exame das normas da Lei Federal n. 9.782/99, responsável pela instituição da ANVISA, identificou-se a existência de somente um artigo relacionado com a apresentação de recursos administrativos. O art. 15, VI da Lei Federal n. 9.782/99 determina o cabimento de recurso administrativo à diretoria colegiada, em última 
instância, contra decisões da agência, sendo que o art. $15, \S 2^{\circ}$ estabelece a possibilidade de atribuir-lhe efeito suspensivo mediante solicitação do interessado.

Novamente trata-se de norma recursal relacionada com processos administrativos em que os legitimados para interposição recursal geralmente são os agentes regulados, ou seja, nos quais haja decisões relacionadas diretamente com a atividade regulatória da agência federal em questão.

\subsection{Agências reguladoras instituídas posteriormente a Lei Federal n. 9.784/99}

Posteriormente a publicação da Lei Federal n. 9.784/99 foram criadas mais seis agências reguladoras federais, a saber: (i) Agência Nacional de Saúde Suplementar (ANS), (ii) a Agência Nacional de Águas (ANA), (iii) a Agência Nacional do Cinema (ANCINE), (iv) a Agência Nacional de Transportes Aquaviários (ANTAQ), (v) a Agência Nacional de Transportes Terrestres (ANTT) e a (vii) Agência Nacional de Aviação Civil (ANAC).

Contudo, em função do extenso período de tramitação de seus projetos de lei no Congresso Nacional, muitas dessas agências reguladoras tiveram suas legislações concebidas anteriormente à publicação da lei de processo administrativo federal, não tendo sido, portanto, direta ou indiretamente influenciadas pelas normas gerais de processo administrativo introduzidas pela Lei Federal n. 9.784/99.

De qualquer maneira, conforme explicado no item 3.1 desse capítulo, o legislador infraconstitucional não poderia deixar de contemplar o devido processo legal administrativo (art. 5, LV CF/88) e os demais princípios administrativos (art. 37, caput $\mathrm{CF} / 88$ ) na redação desses diplomas normativos, fato que deveria se refletir na existência de artigos que expressamente assegurassem tais garantias processuais administrativas.

Considerando-se essas informações, o quadro esquemático abaixo possui como escopo a organização dos dispositivos normativos encontrados nas legislações das agências reguladoras instituídas posteriormente a Lei Federal n. 9.784/99 em função da espécie recursal por ele prevista: 


\begin{tabular}{|c|c|c|c|c|c|}
\hline & ANS & ANA & ANCINE & ANTAQ/ANTT & ANAC \\
\hline & $\begin{array}{l}\text { Lei Federal no 9961/00 } \\
\text { Decreto } n^{\circ} 3327 / 00\end{array}$ & $\begin{array}{c}\text { Lei Federal } \mathbf{n}^{\circ} \\
9984 / 00\end{array}$ & MP no 2228-1/01 & $\begin{array}{l}\text { Lei Federal } n^{0} 10233 / 01 \\
\text { Decreto } n^{\circ} 4122 / 02 \\
\text { Decreto } n^{\circ} 4130 / 02\end{array}$ & Lei Federal no 11182/05 \\
\hline $\begin{array}{c}\text { Recurso } \\
\text { Administrativo }\end{array}$ & 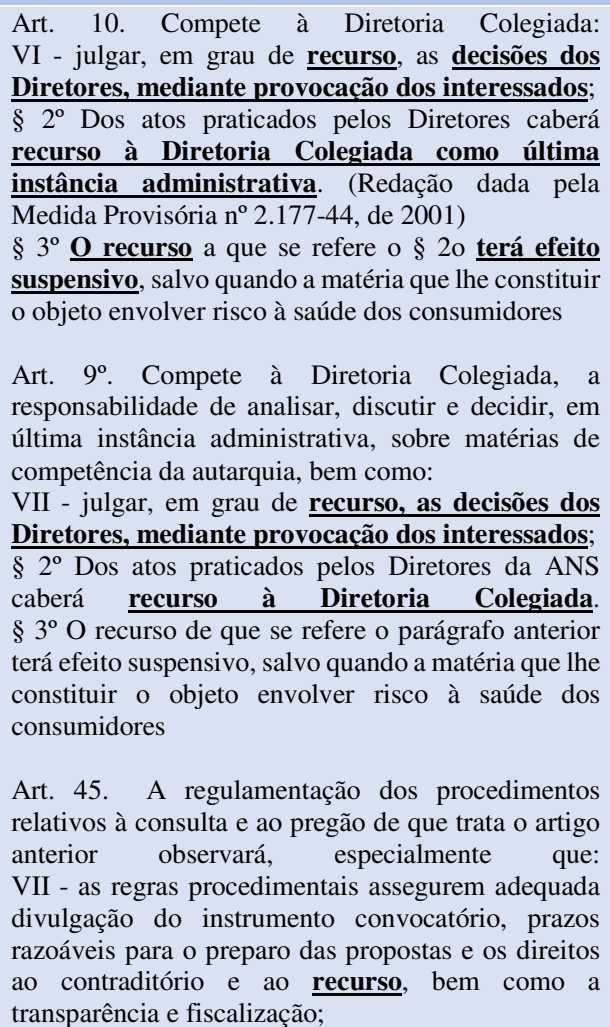 & - & $\begin{array}{l}\text { Art. 9. Compete à Diretoria } \\
\text { Colegiada da ANCINE: } \\
\text { IX - julgar recursos } \\
\text { interpostos } \frac{\text { contra }}{\text { decisões de membros da }} \\
\text { Diretoria }\end{array}$ & 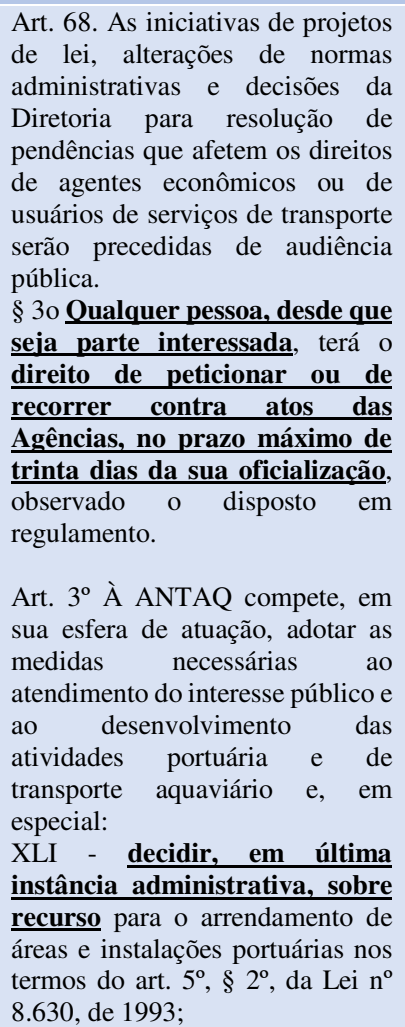 & $\begin{array}{l}\text { Art. 11. Compete à Diretoria: } \\
\text { VIII - apreciar, em grau de } \underline{\text { recurso }} \text {, as } \\
\text { penalidades impostas pela ANAC }\end{array}$ \\
\hline
\end{tabular}




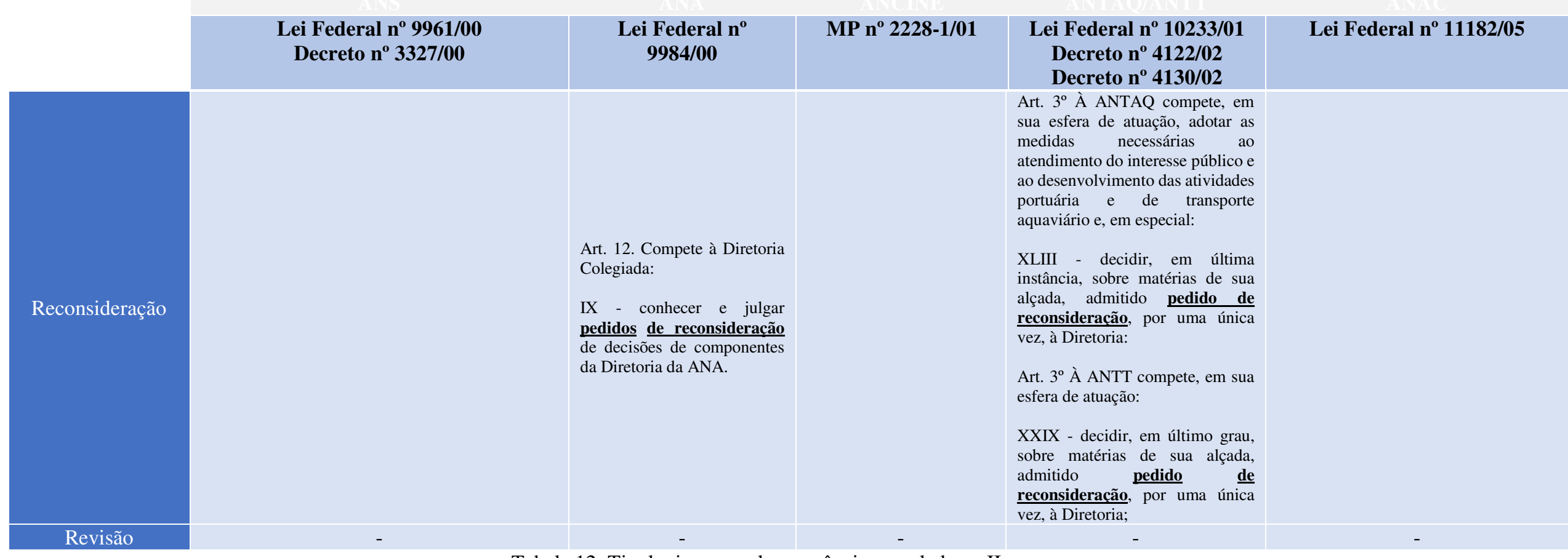

Tabela 12: Tipologia recursal nas agências reguladoras II

Fonte: elaboração própria a partir da Lei Federal n. 9.961/00, Decreto n. 3.327/00, Lei Federal n. 9.984/00, MP n. 2.228-1/01, Lei Federal n. 10.233/01, Decreto n. 4.122/02,

Decreto n. 4.130/02 e Lei Federal n. 11.182/05 
Majoritariamente, os dispositivos normativos encontrados na legislação básica das agências reguladoras instituídas posteriormente a Lei Federal n. 9.784/99 apresentam disposições relacionadas com o cabimento de recurso administrativo. Em relação ao pedido de reconsideração, somente metade das agências (a saber: ANA, ANTAQ e ANTT) consideradas expressam normas orientadoras de seu cabimento. Finalmente, nenhuma das legislações examinadas apresentou quaisquer regras referentes a revisão administrativa.

Passa-se, a seguir, ao diagnóstico de cada uma dessas agências.

\section{a) ANS (Lei Federal n. 9.961/00 e Decreto n. 3.327/00)}

Instituída pela Lei Federal n. 9.961/00 para promoção da "defesa do interesse público na assistência suplementar à saúde, regular as operadoras setoriais - inclusive quanto às suas relações com prestadores e consumidores - e contribuir para o desenvolvimento das ações de saúde no país", a ANS é responsável pela regulação setorial de um dos maiores sistemas privados de saúde do mundo (ANS, 2015).

Objetivando tornar mais preciso o diagnóstico das garantias recursais nessa agência, foram examinadas duas legislações: a Lei Federal n. 9.961/00, lei instituidora da ANS e o Decreto n. 3.327/00, responsável pela aprovação do regulamento da ANS.

O art. 10, VI da Lei Federal n. 9.961/00 estabelece a competência da diretoria colegiada para julgar em última instância (art. 10, $\S 2^{\circ}$ ) os recursos administrativos interpostos contra decisões proferidas pelos diretores, podendo-lhe ser atribuído efeito suspensivo sempre que não se tratar de matéria que possa envolver risco à saúde dos consumidores (art. 10, $\S 3^{\circ}$ ). Segundo a redação do dispositivo normativo, as decisões objeto dos recursos administrativos são aquelas proferidas pelos diretores da agência no âmbito de sua competência decisória, motivo pelo qual muito provavelmente esse recurso administrativo possua como legitimados as empresas de planos de saúde (agentes regulados $)^{162}$.

Por sua vez, o art. 45, VI do Decreto n. 3.327/00 determina que as regras procedimentais relativas à consulta e ao pregão deverão assegurar, entre outras coisas, o direito ao recurso. Nesse sentido, o dispositivo normativo procura garantir que os procedimentos administrativos decorrentes do processo licitatório consulta ou do

162 O inciso VII e os $\S \S 2^{\circ}$ e $3^{\circ}$ do art. 9 do Decreto n. 3.327/00 apenas repetem a redação do dispositivo normativo da Lei Federal n. 9.961/00 acima analisado, nada acrescentando. 
processo licitatório pregão estejam em conformidade com o devido processo legal administrativo e o direito de recorrer.

\section{b) ANA (Lei Federal n. 9.984/00)}

A Lei Federal n. 9.984/00 fundou a Agência Nacional de Águas (ANA), cuja missão é implementar e coordenar a gestão compartilhada e integrada dos recursos hídricos e regular o acesso a água, promovendo seu uso sustentável em benefício das atuais e futuras gerações.

Diferentemente da maioria das agências reguladoras, o art. 12, IX da Lei Federal n. 9.984/00 prevê o cabimento de pedido de reconsideração das decisões da diretoria da agência para a diretoria colegiada.

Embora o pedido de reconsideração geralmente seja direcionado para a própria autoridade administrativa que proferiu a decisão, segundo o art. 12, IX da Lei Federal n. 9.984/00, o encaminhamento desse pedido no âmbito da ANA será feito para a diretoria colegiada. Observe-se o organograma abaixo:

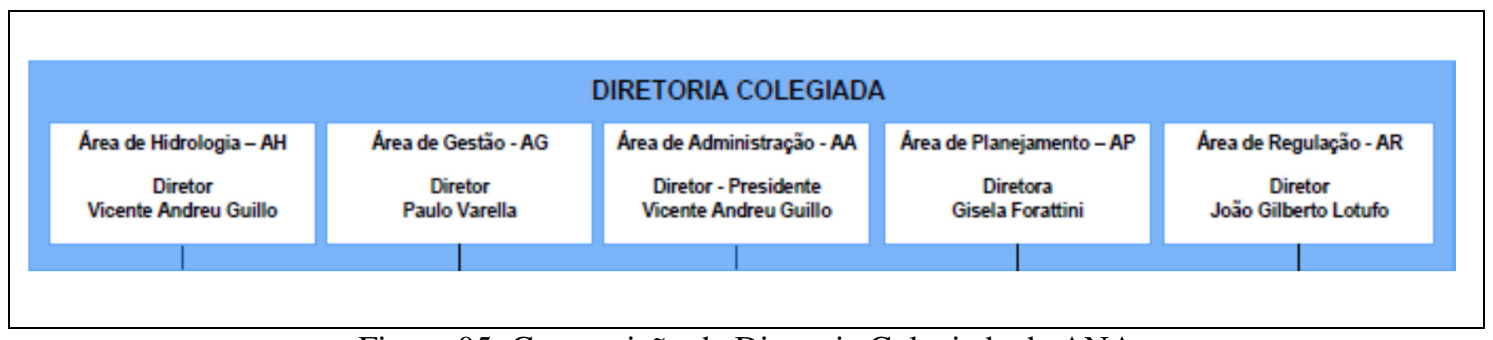

Figura 05: Composição da Diretoria Colegiada da ANA

Fonte: ANA, 2015

A Diretoria Colegiada é formada pelos diretores (i) da área de hidrologia, (ii) da área de gestão, (iii) da área de administração, (iv) da área de planejamento e (v) da área de regulação.

Segundo o art. 12, IX da Lei Federal n. 9.984/00, das decisões do diretor da área de planejamento, por exemplo, caberá pedido de reconsideração à diretoria colegiada. Tecnicamente, o pedido de reconsideração determinado pelo art. 12, IX da Lei Federal n. 9.984/00 deveria receber a denominação de recurso administrativo, pois desloca a competência do processamento e julgamento do pedido apresentado à autoridade administrativa hierarquicamente superior. 


\section{c) ANCINE (MP n. 2.228-1/01)}

Em atendimento às reivindicações do III Congresso Brasileiro de Cinema, que pediam a criação de um órgão gestor da atividade cinematográfica, o presidente Fernando Henrique Cardoso baixou, em 6 de setembro de 2001, a Medida Provisória n. 2.228-1/01, que instituiu a ANCINE, agência reguladora com o objetivo de fomento, regulação e fiscalização da indústria cinematográfica e videofonográfica nacional.

Em relação às garantias recursais, o art. $9^{\circ}$, IX da MP n. 2.228-1/01 estabelece o cabimento de recurso administrativo contra decisões dos membros da diretoria à diretoria colegiada da ANCINE. Sob a perspectiva desse dispositivo normativo, os agentes regulados poderão interpor recurso administrativo à diretoria colegiada contra decisão proferida por quaisquer dos quatro diretores.

\section{d) ANTAQ e ANTT (Lei Federal n. 10.233/01, Decreto n. 4.122/02 e Decreto n.}

\subsection{0/02)}

Com a finalidade de regulamentar os setores de transportes aquaviários e terrestres, a Lei Federal n. 10.233/01 criou, simultaneamente, a Agência Nacional de Transportes Terrestres (art. ${ }^{\circ}$, III) e a Agência Nacional de Transportes Aquaviários (art. $\left.1^{\mathrm{o}}, \mathrm{IV}\right)$.

A Agência Nacional de Transportes Terrestres (ANTT) tem como missão assegurar aos cidadãos adequada prestação de serviços de transporte terrestre, por meio da regulação e fiscalização do (i) transporte ferroviário: exploração da infraestrutura ferroviária, prestação do serviço público de transporte ferroviário de cargas e prestação do serviço público de transporte ferroviário de passageiros, (ii) transporte rodoviário: exploração da infraestrutura rodoviária, prestação do serviço público de transporte rodoviário de passageiros, e prestação do serviço de transporte rodoviário de cargas, (iii) transporte dutoviário: cadastro de dutovias, (iv) transporte multimodal: habilitação do Operador de Transportes Multimodal, (v) terminais e vias: exploração (ANTT, 2015).

Por sua vez, a Agência Nacional de Transportes Aquaviários (ANTAQ) dedica-se a (i) "tornar mais econômica e segura a movimentação de pessoas e bens pelas vias aquaviárias brasileiras, em cumprimento a padrões de eficiência, segurança, conforto, regularidade, pontualidade e modicidade nos fretes e tarifas", (i) "arbitrar conflitos de interesses para impedir situações que configurem competição imperfeita ou infração 
contra a ordem econômica" e (iii) "harmonizar os interesses dos usuários com os das empresas e entidades do setor, sempre preservando o interesse público" (ANTAQ, 2015).

Visando ao diagnóstico das garantias recursais nos processos administrativos da ANTT e da ANTQ, foram verificados os seguintes diplomas normativos: (i) a Lei Federal n. 10.233/01, que é o instrumento normativo instituidor dessas agências; (ii) o Decreto $n$. 4.122/02, que estabelece o regulamento e o quadro demonstrativo dos cargos comissionados e dos cargos comissionados técnicos da ANTAQ; e (iii) o Decreto $\mathrm{n}$. 4.130/02, que define o regulamento e o quadro demonstrativo dos cargos comissionados e dos cargos comissionados técnicos da ANTT.

$\mathrm{O}$ art. 68 da Lei Federal n. 10.233/01 possui um escopo bastante extenso, disciplinando questões relacionadas com as iniciativas de projetos de lei, as alterações das normas administrativas e das decisões da diretoria que afetem os direitos dos agentes regulados e dos usuários de serviços. Em relação às decisões da diretoria das agências, o art. $68, \S 3^{\circ}$ determina que: (i) todos os cidadãos que demonstrem serem destinatários integrais dos efeitos do ato administrativo da agência ou tenham sofrido reflexos jurídicos por conta da edição do ato administrativo da agência (CARNEIRO, 2003, p.20) estão legitimados a (ii) peticionar ou recorrer (iii) no prazo máximo de trinta dias da oficialização desse ato. De acordo com a redação desse dispositivo normativo, tanto os usuários dos serviços de transporte terrestre e aquaviário quanto as empresas prestadoras desses serviços possuem a prerrogativa de questionamento das decisões dos atos dessas agências reguladoras, desde que comprovadamente tenham interesse na modificação do ato administrativo questionado. Trata-se, na verdade, da instrumentalização da garantia constitucional ao direito de petição (art. $5^{\circ}, \mathrm{XXXIV} \mathrm{CF/88),} \mathrm{universalizando-o} \mathrm{a} \mathrm{todos}$ aqueles que constituam relação direta ou indireta com as decisões proferidas por quaisquer dessas duas agências.

O Decreto n. 4.122/02, responsável por aprovar o regulamento interno e o quadro demonstrativo dos cargos, organiza questões relacionadas exclusivamente com a ANTAQ. Em relação aos recursos administrativos, o decreto apresenta um artigo com dois incisos tratando sobre o tema. $\mathrm{O}$ art. $3^{\circ}$, caput dispõe que o exercício das atividades regulatórias pela ANTAQ pressupõe a adoção de medidas voltadas ao atendimento do interesse público, sendo que, dentre essas medidas, será competente para o processamento e julgamento em última instância dos recursos administrativos cujo objeto seja o arrendamento de áreas e instalações portuárias (art. $3^{\circ}$, XLI) e dos pedidos de reconsideração relacionados com matéria de sua alçada (art. $3^{\circ}$, XLIII). Na verdade, o art. 
$3^{\circ}$ do Decreto n. 4.122/02 destaca-se por situar a ANTAQ dentre as poucas agências reguladoras a terem previsão expressa de pedido de reconsideração em sua legislação base.

Por sua vez, o Decreto n. 4.130/02, no qual há a aprovação do regulamento interno e o quadro demonstrativo dos cargos, dispõe somente sobre questões envolvendo a ANTT. Assim como no caso anterior, apenas um artigo relacionado aos recursos administrativos foi encontrado no decreto da ANTT. O art. $3^{\circ}$, XXIX do Decreto $\mathrm{n}$. 4.130/02 somente prescreve a competência da agência para o processamento e julgamento do pedido de reconsideração por sua diretoria. Portanto, ainda que seja mais econômico em relação ao decreto da outra agência, art. $3^{\circ}$, XXIX é um dos poucos dispositivos normativos a adotar a possibilidade de apresentação de pedido de reconsideração.

\section{e) ANAC (Lei Federal n. 11.182/05)}

A reformulação do ente público responsável pela regulação do setor de transporte aéreo somente aconteceu em 2005, com a instituição da Agência Nacional de Aviação Civil (ANAC) por meio da Lei Federal n. 11.182/05, em substituição ao Departamento de Aviação Civil (DAC). As atribuições dessa agência são a regulação e a fiscalização das atividades de aviação civil e infraestrutura aeronáutica e aeroportuária (ANAC, 2015).

Por meio da análise da Lei Federal n. 11.182/05 constatou-se a existência de somente um dispositivo normativo referente às garantias recursais. Assim, o art. 11, VIII da Lei Federal n. 11.182/05 estabelece a competência da diretoria da agência para processamento e julgamento de recurso administrativo interposto contra decisão que determinou a aplicação de penalidade ao agente regulado.

\subsection{Considerações acerca das legislações infraconstitucionais básicas das agências reguladoras}

A análise das legislações infraconstitucionais básicas permitiu a constatação da necessidade da existência de outros documentos para o estabelecimento de regras processuais viabilizadoras do exercício das competências decisórias no âmbito das agências reguladoras federais, pois somente as regras processuais previstas pelas 
legislações básicas não são suficientes para regulamentar as especificidades dos processos administrativos desenvolvidos pelos entes públicos regulatórios.

Dessa maneira, além da aplicação subsidiária da Lei Federal n. 9.784/99, as agências reguladoras federais devem contar com documentos próprios que estabeleçam as regras aplicáveis aos seus processos administrativos, tais como: as competências dos agentes públicos para processamento e julgamento, os procedimentos a serem adotados, as espécies recursais instrumentalizadoras do direito de recorrer em cada caso, entre outras.

No caso das agências reguladoras federais, esses documentos possuem natureza jurídica de ato administrativo e podem assumir a forma de resoluções, portarias, circulares, regimentos internos, deliberações e instruções, representando a concretização do poder regulamentar conferido ao poder executivo pelo art. $49, \mathrm{~V} \mathrm{CF} / 88^{163}$.

Entretanto, não será realizada a sistematização dos recursos administrativos instituídos por esses documentos, pois ainda que pudesse ser extremamente interessante o diagnóstico específico das garantias recursais constantes desses documentos, o esforço de sistematização esbarraria em três obstáculos: (i) o número elevado de documentos relacionados com processo administrativo em cada agência reguladora, (ii) a dificuldade em se localizar todos os documentos editados por cada agência; (iii) o fato de que esses documentos costumam ser substituídos quando ocorre mudança de gestão nas agências reguladoras.

Assim, considerando-se exclusivamente as legislações infraconstitucionais básicas das agências reguladoras, constatou-se que: (i) o legislador infraconstitucional não demonstrou muita preocupação com o estabelecimento de normas processuais, (ii) as regras processuais concentram-se quase que unicamente no cabimento do recurso hierárquico próprio, (iii) o devido processo legal administrativo e os demais princípios administrativos são mencionados poucas vezes e de maneira genérica, (iv) essas legislações tornam o processo administrativo das agências reguladoras altamente dependente da aplicação subsidiária da Lei Federal n. 9.784/99 e da existência de outras normas disciplinadoras.

163 “Insere-se, portanto, o poder regulamentar como uma das formas pelas quais se expressa a função normativa do Poder Executivo. Pode ser definido como o que cabe ao Chefe do Poder Executivo da União, dos Estados e dos Municípios, de editar normas complementares à lei, para sua fiel execução" (DI PIETRO, 2011, p. 91) 


\section{CONSIDERAÇÕES FINAIS}

O processo administrativo é um mecanismo extremamente importante para a efetivação dos direitos e garantias constitucionais. Por meio do processo administrativo, os agentes públicos desenvolvem a função administrativa e os cidadãos podem exercer seus direitos individuais e participar do processo decisório da Administração Pública.

A constitucionalização do processo administrativo (art. $5^{\circ}, \mathrm{LV}$ ), a reforma administrativa ocorrida na década de 90 e a publicação da Lei Federal n. 9.784/99 estabeleceram uma mudança na mentalidade da Administração Pública, que passou a priorizar a eficiência administrativa e a participação popular como metas balizadoras da função administrativa.

Em que medida essas alterações no tratamento dispensado ao processo administrativo impactou na atividade cotidiana da administração pública federal?

Essa pesquisa acadêmica buscou identificar as principais garantias processuais constitucionalmente previstas e relacioná-las com a aplicação das regras instrumentalizadoras do direito de recorrer no âmbito do processo administrativo federal. Para tanto, desenvolveu a análise das principais legislações administrativas federais, buscando identificar a previsão de regras disciplinadoras do cabimento, processamento e julgamento dos recursos administrativos e a extensão da influência do princípio do devido processo legal administrativo nessas regras.

O primeiro capítulo procurou apontar os aspectos históricos formadores da lógica contemporânea do processo administrativo, para que fosse possível estabelecer os pressupostos principiológicos que sustentam o sistema recursal inscrito nesse modelo de processo administrativo. Assim, a primeira parte desse trabalho foi essencial para se determinar as bases que fundamentaram as regras recursais previstas na Lei Federal n. 9.784/99.

Baseando-se esses aspectos históricos e conceituais apresentados no primeiro capítulo, o segundo capítulo cuidou de delinear as características do sistema recursal estabelecido pela Lei Federal n. 9.784/99, determinando as espécies recursais existentes, suas especificidades e as regras à elas aplicáveis. Na verdade, o segundo capítulo buscou indicar o conjunto de regras recursais que serviriam de modelo para o diagnóstico a ser desenvolvido no terceiro capítulo. 
Os elementos necessários para responder a pergunta norteadora dessa pesquisa acadêmica foram encontrados por meio do desenvolvimento de um diagnóstico das legislações administrativas federais no terceiro capítulo.

A Lei Federal n. 8.112/90, responsável por determinar o regime jurídico dos servidores públicos federais, é bastante abrangente quanto ao estabelecimento de garantias asseguradoras do devido processo legal administrativo no âmbito dos recursos administrativo. Praticamente não se existem lacunas normativas a serem preenchidas subsidiariamente pela Lei Federal n. 9.784/99 e ainda pode-se destacar a possibilidade de apresentação de pedido de reconsideração, recurso hierárquico e revisão administrativo e o estabelecimento de prazos maiores, possibilitando ao cidadão a elaboração de um requerimento melhor instrumentalizado.

Por sua vez, a Lei Federal n. 8.666/93, instituidora das regras de licitação e contratação pública, não apresenta um número significativo de regras processuais disciplinadoras dos recursos administrativos, deixando praticamente a cargo de um único artigo o estabelecimento das garantias recursais no processo administrativo licitatório.

Finalmente, a análise das legislações básicas das agências reguladoras identificou a necessidade da existência de outras normas administrativas para que seja possível alcançar as medidas suficientes para a promoção das garantias constitucionais no processo administrativo no âmbito das agências reguladoras, vez que as legislações básicas são praticamente omissas quanto ao estabelecimento de regras recursais ou garantidoras de direitos.

Para além da aplicação dessas legislações federais analisadas, é imprescindível que o agente público não afaste a aplicação da Lei Federal n. 9.784/99 no âmbito do processo administrativo do ente público em que se encontra lotado. Na verdade, constatou-se que o melhor modelo de aplicação, visando à efetivação do devido processo legal administrativo e demais garantias processuais administrativas constitucionalmente previstas, é aquele que conjuga as especificidades previstas nas legislações infraconstitucionais e as normas gerais determinadas pela Lei Federal n. 9.784/99.

Dentro da perspectiva implementada pela reforma administrativa e pela constitucionalização do processo administrativo, sempre que o agente público desempenhar a função administrativa considerando a aplicação dos princípios constitucionais, as normas gerais da Lei Federal n. 9.784/99 e as regras específicas da legislação federal ao qual encontra-se submetido, então certamente poderá se esperar uma ampliação dos direitos e garantias fundamentais dos cidadãos, realizando os ditames de 
eficiência administrativa e participação popular delineados pela implementação do modelo de gestão gerencial e gestão societal.

Essa revisão normativa encerra uma das hipóteses de verificação da eficiência administrativa e da participação popular em concreto. Espera-se que a partir dessa leitura, seja possível incentivar e promover novas pesquisas acadêmicas, adotando-se novas perspectivas sobre a aplicação das normas processuais administrativas e dos efeitos dessa aplicação nas relações jurídicas entre a Administração Pública e os cidadãos.

Assim, encerra-se essa sistematização dos recursos administrativos na legislação federal indagando-se se a aplicação das normas processuais pelos agentes públicos federais efetivamente contempla as garantias recursais analisadas ou a necessidade de conjugação de diversas normas para se assegurar essas garantias abre a possibilidade de um comportamento arbitrário, em que o agente público escolhe quais regras devem ser efetivamente aplicadas, em detrimento da maior medida garantista possível. 


\section{REFERÊNCIAS BIBLIOGRÁFICAS}

AGÊNCIA NACIONAL DE ENERGIA ELÉTRICA. Descentralização de atividades. Brasília: ANEEL, 2005 (Cadernos Temáticos ANEEL)

ALMEIDA, Fernando Dias Menezes de. Formação da teoria do direito administrativo no Brasil. Tese (Titularidade em Direito) - Faculdade de Direito, Universidade de São Paulo, São Paulo, 439 p., 2013.

ANA. Portal ANA. Disponível em <http://www.ana.gov.br/>. Acesso em 08 mar 2015.

ANAC. Portal ANAC. Disponível em <http://www.anac.gov.br/>. Acesso em 08 mar 2015.

ANATEL. Portal ANATEL. Disponível em <http://www.anatel.gov.br/>. Acesso em 08 $\operatorname{mar} 2015$.

ANP. Portal ANP. Disponível em <http://www.anp.gov.br/>. Acesso em 08 mar 2015.

ANS. Portal ANS. Disponível em <http://www.ans.gov.br/>. Acesso em 08 mar 2015.

ANTT. Portal ANTT. Disponível em <http://www.antt.gov.br/>. Acesso em 08 mar 2015.

ANTAQ. Portal ANTAQ. Disponível em <http://www.antaq.gov.br/>. Acesso em 08 mar 2015.

BACELLAR FILHO, Romeu Felipe. Processo administrativo disciplinar. 4. ed., São Paulo: Saraiva, 2013.

BARROS JÚNIOR, Carlos Schmit de. Recursos administrativo. Revista de Direito Administrativo. v.13, pp. 40-55, 1948. Disponível em < http://bibliotecadigital.fgv.br/ojs/index.php/rda/article/view/10671/9665>. Acesso em 30 ago 2014.

BARROS JÚNIOR, Carlos Schmit de. A codificação do direito administrativo. Revista de Direito Administrativo. v.18, pp. 1-7, 1949. Disponível em < http://bibliotecadigital.fgv.br/ojs/index.php/rda/article/view/11175/10144>. Acesso em 30 ago 2014.

BINENBOJM, Gustavo. O sentido da vinculação administrativa à juridicidade no direito brasileiro in ARAGÃO, Alexandre Santos de; MARQUES NETO, Floriano de Azevedo (coord). Direito administrativo e seus novos paradigmas. Belo Horizonte: Fórum, 2012.

CARNEIRO, Athos Gusmão. Intervenção de terceiros. 14 ed., rev. e atual. São Paulo: Saraiva, 2003. 
CARVALHO FILHO, José dos Santos. Processo administrativo federal: comentários à lei no 9,784/99, de 29.1.1999. 5. ed., rev., amp. e atual., São Paulo: Atlas, 2013.

CARVALHO NETO, Tarcísio Vieira de. Controle jurisdicional da administração pública: algumas ideias. Revista de informação legislativa. Brasília, ano 50, n. 199, pp. 121-142, jul-set 2013. Disponível em <http://www2.senado.leg.br/bdsf/bitstream/handle/id/502968/RIL199.pdf?sequence=1> . Acesso em: 20 jan 2015.

CAVALCANTI, Themístocles Brandão. A unificação das normas do processo administrativo. Arquivos do Ministério da Justiça, v. 33, n. 139, p. 1-31, jul./set., 1976.

CENTRO de Pesquisa e Documentação de História Contemporânea do Brasil. Constituição de 1937. Navegando na História. Rio de Janeiro, 1997. Disponível em < http://cpdoc.fgv.br/producao/dossies/AEraVargas1/anos37-

45/PoliticaAdministracao/Constituicao1937 >. Acesso em 30 ago 2014.

CENTRO de Pesquisa e Documentação de História Contemporânea do Brasil. Constituição de 1937. Navegando na História. Rio de Janeiro, 2004. Disponível em < http://cpdoc.fgv.br/producao/dossies/AEraVargas2/artigos/DoisGovernos/Constituicao1 $946>$. Acesso em 30 ago 2014.

CLÈVE. Clèmerson Merlin. O cidadão, a administração pública e a nova Constituição. Revista de informação legislativa, Brasília, ano 27, n. 106, pp. 81-98, abr./jun. 1990.

COSTA, José Armando da. Teoria e prática do processo administrativo disciplinar. 5.ed., Brasília: Brasília Jurídica, 2005.

CRETELla JÚNIOR, José. Tratado de direito administrativo. Rio de Janeiro, Forense, 1970, v. VI.

CRETELLA JÚNIOR, José. Lições de direito administrativo. 2.ed., São Paulo: José Bushatsky, 1972.

CUNHA, Luciana Gross; GABBAY, Daniela Monteiro (org.). Litigiosidade, morosidade e litigância repetitiva no judiciário: uma análise empírica. São Paulo: Saraiva, 2012.

CUNHA, Luciana Gross; BUENO, Rodrigo De Losso Silveira; OLIVEIRA, Fabiana Luci de; SAMPAIO, Joelson de Oliveira; RAMOS, Luciana de Oliveira; MACEDO, Gabriel Hideo Sakai de. Relatório ICJBrasil: $2^{\circ}$ trimestre/2013 - $1^{\circ}$ trimestre/2014: ano 5. São Paulo: FGV Direito SP, 2014.

DALLARI, Adilson de Abreu; FERRAZ, Sérgio. Processo administrativo. 3. ed., São Paulo: Malheiros Editores, 2012. 
DIAS, Maria Berenice. Reconsideração versus revisão: uma distinção que se impõe. Disponível em <http://www.mariaberenice.com.br/uploads/5__reconsidera\%E7\%E3o_versus_revis\%E3o_uma_distin\%E7\%E3o_que_se_imp \%F5e. pdf $>$. Acesso em 01 mar 2015.

DIAS, Luciano Nendza. O Papel das Agências Reguladoras no Brasil. Intertem@as. Presidente Prudente: Toledo, v. 20, n. 20, 2010.

DIDIER, Fredie. Curso de Direito Processual Civil. 4. ed., Salvador: Editora Juspodivm, vol. II, 2009.

DI PIETRO, Maria Sylvia Zanella. Direito administrativo. 24. ed., São Paulo: Atlas, 2011.

DI PIETRO, Maria Sylvia Zanella. Limites da utilização de princípios do processo judicial no processo administrativo. Fórum Administrativo, Belo Horizonte, v. 13, n. 147, maio 2013. Disponível em: $<$ http://dspace/xmlui/bitstream/item/6125/PDIexibepdf.pdf?sequence=1>. Acesso em: 19 jan. 2015.

DI PIETRO, Maria Sylvia Zanella. Mandado de segurança: ato coator e autoridade coatora in GONÇALVES, Aroldo Plínio; GRINOVER, Ada Pellegrini et al. (coord). Mandado de segurança. Imprenta: Belo Horizonte, Del Rey, p. 147-165, 1996.

DUGUIT, Léon. Manuel de droit constitucionel. 4. ed., Paris: Pathéon Assas, 1923.

DUSSAULT, G. A gestão dos serviços públicos de saúde: características e exigências. Revista de Administração Pública, Rio de Janeiro, v. 26, n. 2, p. 8-19, abr./jun. 1992.

FAGUNDES, Miguel Seabra. Dos recursos ordinários em matéria civil. Rio de Janeiro: Forense, 1946.

FALCÃO, Joaquim; ABRAMOVAY, Pedro; LEAL, Fernando; HARTMANN, Ivar A. II Relatório Supremo em Números: O Supremo e a Federação. Rio de Janeiro: Escola de Direito do Rio de Janeiro da Fundação Getulio Vargas, 2013.

FERREIRA, Aurélio Buarque de Holanda. Miniaurélio: o dicionário da língua portuguesa. 6.ed. rev. atual, Curitiba: Positivo, 2006.

FORTINI, Cristina; PEREIRA, Maria Fernanda Pires de Carvalho; CAMARÃO, Tatiana Martins da Costa. Processo administrativo: comentários à Lei n ${ }^{\circ}$ 9.784/99. Belo Horizonte: Fórum, 2012.

FRANCO SOBRINHO, Manoel de Oliveira. Introdução ao direito processual administrativo. São Paulo: Revista dos Tribunais, 1971. 
FREITAS, Izaías Dantas. A finalidade da pena no direito administrativo disciplinar. Revista de informação legislativa, v. 36, n. 141, p. 119-128, jan.- mar. 1999.

GASPARINI, Diógenes. Direito administrativo. 4. ed. São Paulo: Saraiva, 1995.

GUEDES, Demian. Processo administrativo e democracia. Belo Horizonte: Fórum, 2007.

GUEDES, Jefferson Carús. Duplo grau ou duplo exame e a atenuação do reexame necessário nas leis brasileiras in NERY JUNIOR, Nelson; WAMBIER, Teresa Arruda Alvim (coord.). Aspectos polêmicos e atuais dos recursos e de outros meios de impugnação às decisões judiciais. São Paulo: Revista dos Tribunais, 2002.

GUIMARÃES, Fernando Vernalha. O conceito de norma geral e a regra do valor mínimo às parcerias público-privadas (inciso $I$ do $\$ 4^{\circ}$ do art. $2^{\circ}$ da Lei n. 11.079/2004). Revista Eletrônica de Direito Administrativo Econômico (REDAE), Salvador, Instituto Brasileiro de Direito Público n.18, maio/jun/jul, 2009. Disponível em $<$ http://www.direitodoestado.com>. Acesso em: 29 de outubro de 2014.

HAMILTON, Alexander; MADISON, James; JAY, John. O Federalista. Brasília: Editora Universidade de Brasília, 1984.

JORGE, Flávio Cheim. Teoria geral dos recursos cíveis. 3.ed. rev. ampl. e atual., São Paulo: Revista dos Tribunais, 2007.

JUSTEN FILHO, Marçal. Comentários à lei de licitações e contratos administrativos. 14. ed., São Paulo: Dialética, 2010.

LASPRO, Oreste Nestor de Souza. Duplo grau de jurisdição no direito processual civil. São Paulo: Revista dos Tribunais, 1995.

LEITE, Fábio Carvalho. 1891: A Construção da Matriz Político-Institucional da República no Brasil. 2003. 218 f. Dissertação (Mestrado) - Pontifícia Universidade Católica do Rio de Janeiro, Rio de Janeiro. 2003

LIEBMAN, Enrico Tullio. Estudo sobre o processo civil brasileiro. São Paulo: Bestbook, 2001.

LUCON, Paulo Henrique dos Santos. Garantia do tratamento paritário das partes in TUCCI, José Rogério Cruz e. Garantias Constitucionais no Processo Civil: Homenagem aos 10 Anos da Constituição Federal de 1988. São Paulo: Revista dos Tribunais, 1998.

LUHMANN, Niklas. Legitimação pelo procedimento. Tradução: Maria da Conceição. Brasília: UNB, 1980.

MARINONI, Luiz Guilherme; ARENHART, Sérgio Cruz. Processo de Conhecimento. 9. ed. rev. e atual., São Paulo: Editora Revista dos Tribunais, 2011. 
MARRARA, Thiago; NOHARA, Irene Patrícia. Processo Administrativo: Lei n 9.784/99 comentada. São Paulo: Atlas, 2009.

MEDAUAR, Odete. Direito administrativo moderno. 12. ed., São Paulo: Revista dos Tribunais, 2008.

MEDAUAR, Odete. Direito Administrativo Moderno. 14. ed. rev. e atual. São Paulo: Revista dos Tribunais, 2010.

MEDAUAR, Odete. Controle da administração pública. 2. ed. rev. atual. ampl., São Paulo: Revista dos Tribunais, 2012.

MEIRELLES, Hely Lopes. Direito administrativo brasileiro. Rio de Janeiro: Editora Malheiros, 2004.

MEIRELLES, Hely Lopes. Direito administrativo brasileiro. 32 ed. São Paulo: Editora Malheiros, 2006.

MELlO, Celso Antônio Bandeira de. Curso de direito administrativo. 25.ed., São Paulo: Malheiros, 2008.

MELLO, Rafael Munhoz de. Processo administrativo, devido processo legal e a Lei $\mathrm{n}^{\circ}$ 9.784/1999. Revista de Direito Administrativo, n. 227, p. 83-104, 2002.

MENDES, Vera Lúcia Peixoto. Inovação gerencial na administração pública, cidadania e direitos dos Brasileiros. Organizações e Sociedade, Salvador, v. 8, n. 22, dez, 2001. Disponível em: <http://www.scielo.br/>. Acesso em 08 mar. 2015.

MIGALHAS. Fosse para reconsiderar não teria decidido, afirma juiz. Migalhas quentes, 25 set 2014. Disponível em <http://www.migalhas.com.br/Quentes/17,MI208265,31047Fosse+para+reconsiderar+nao+teria+decidido+afirma+juiz>. Acesso em: 19 jan 2015.

MINISTÉRIO DA PREVIDÊNCIA SOCIAL. Requerimento de Pedido de Reconsideração de Benefício por Incapacidade Previdenciário: PR. Disponível em: <http://agencia.previdencia.gov.br/e-aps/servico/423>. Acesso em 03 jan 2015

MODESTO, Paulo. A nova lei do processo administrativo. Jus Navigandi, Teresina, ano 5, n. 38, 1 jan. 2000. Disponível em: <http://jus.com.br/artigos/407>. Acesso em: 3 set. 2014.

MOISES, José Álvaro. A desconfiança nas instituições democráticas. Opinião Pública, Campinas, v. 11, n. 1, pp.33-63, mar 2005.

MOISES, José Álvaro. Dilemas da consolidação democrática no Brasil. Lua Nova, São Paulo, n.16, pp. 47-86, mar 1989. 
MONTESQUIEU, Charles de Secondant. L'Esprit des Lois. Paris, s/d, Livro VI, Capítulo VII.

MORAES, Alexandre de. Direito Constitucional. 27. ed. São Paulo: Atlas, 2011.

MOREIRA, Egon Bockmann. Processo administrativo: Princípios constitucionais e a Lei 9.784/99. 3. ed., São Paulo: Malheiros, 2007.

MOREIRA, José Carlos Barbosa. Comentários ao Código de Processo Civil. 5. ed. rev. atual. Rio de Janeiro: Forense, 1993. v. 5.

MOREIRA, José Carlos Barbosa. Comentários ao Código de Processo Civil. 5. ed. rev. atual. Rio de Janeiro: Forense, 1993. v. 6.

MOREIRA, José Carlos Barbosa. Juízo de admissibilidade no sistema dos recursos civis. Rio de Janeiro: Imprenta, 1968.

NERY JUNIOR, Nelson. Teoria geral dos recursos. 6. ed. atual., ampl. e reform., São Paulo: Editora dos Tribunais, 2004.

NUNES, Edson de Oliveira; NOGUEIRA, André Magalhães; COSTA, Cátia Couto da; ANDRADE, Helenice Vieira de; RIBEIRO, Leandro Molhano. Agências reguladoras e reforma do Estado no Brasil: inovação e continuidade no sistema político institucional. Rio de Janeiro: Garamond, 2007.

PACCE, Carolina Dalla. Controle parlamentar da administração pública na legislação brasileira: a eficácia dos mecanismos de solicitação de informação. Revista Digital de Direito Administrativo, v.1, n.2, 2014. Disponível em <http://www.revistas.usp.br/rdda/article/view/77949>. Acesso em: 20 jan 2015.

PAULA, Ana Paula Paes de. Administração pública brasileira entre o gerencialismo e a gestão social. Revista de administração de empresas, São Paulo, v. 45, n. 1, mar. 2005. Disponível em <http://www.scielo.br>. Acesso em 09 mar 2015.

PAULSEN, Leandro; ÁVILA, René Bergmann; SLIWKA, Ingrid Schroder. Direito Processual Tributário. Porto Alegre: Livraria do Advogado, 2007.

PEREIRA, Luiz Carlos Bresser. A reforma do aparelho do Estado e a Constituição de 1988. Texto para discussão. Brasília: ENAP, n.1, 1995.

PEREIRA JÚNIOR, Jessé Torres. O direito de defesa na Constituição de 1988. Rio de Janeiro: Renovar, 1991.

PIMENTA, Carlos César. A reforma gerencial do Estado brasileiro no contexto das grandes tendências mundiais. Revista de Administração Pública, Rio de Janeiro: Fundação Getulio Vargas, pp. 173-199, set.-out., 1999. 
ROCHA, Carmen Lúcia Antunes. Princípios constitucionais do processo administrativo no direito brasileiro. Revista de Informação Legislativa, n. 136, p. 5-28, out./dez 1997.

SANTOS, Moacyr Amaral. Primeiras linhas de direito processual civil. 4. ed. São Paulo: Saraiva, 1980. v. III.

SANTOS, Moacyr Amaral. Primeiras linhas de direito processual civil. 18. ed. São Paulo: Saraiva, 1995. v. I.

SILVA, Ovídio A. Baptista. Curso de processo civil, volume 1: processo de conhecimento. 7. ed., rev. e atualizada de acordo com o Código Civil de 2002, Rio de Janeiro: Forense, 2006.

SIQUEIRA, Moema Miranda de. Eficácia da administração pública: imposição democrática. Revista de administração de empresas, São Paulo, v. 30, n. 1, pp.65-72, mar 1990 .

SUNDFELD, Carlos Ari. A importância do procedimento administrativo. Revista de Direito Público, n. 84, pp. 64-74, out/dez 1987.

SUNDFELD, Carlos Ari; MUÑOZ, Guillermo Andrés (coord). As leis de processo administrativo: Lei Federal 9.784/99 e Lei Paulista 10.177/98. 1. ed., São Paulo: Malheiros, 2006.

TÁCITO, Caio. Notas e comentários. Revista de Direito Administrativo, Rio de Janeiro, n. 205, 349-357, jul/set, 1996.

UNIVERSIDADE DE SÃO PAULO. Dedalus. Disponível em: < http://dedalus.usp.br/F?RN=47537223>. Acesso em: 28 de outubro de 2014.

VELOSO, Waldir de Pinho. Direito processual administrativo. 3. ed., Curitiba: Juruá, 2012.

VERSIANI, Maria Helena. Uma República na Constituinte (1985-1988). Revista Brasileira de História. São Paulo, v. 30, n. 60, p. 233-252, 2010.

WAMBIER, Teresa Celina de Arruda Alvim. Os agravos no Código de Processo Civil brasileiro. 4.ed., São Paulo: Revista dos Tribunais, 2006. 